\title{
Learning across \\ Generations in Europe
}

\section{Contemporary Issues in Older Adult} Education

Bernhard Schmidt-Hertha, Sabina Jelenc Krašovec, and Marvin Formosa (Eds.)

Sense Publishers

IFE도년 
Learning across Generations in Europe 


\section{RESEARCH ON THE EDUCATION AND LEARNING OF ADULTS}

VOLUME 2

\section{Series Editors}

(On behalf of the European Society for Research on the Education of Adults)

Emilio Lucio-Villegas (University of Seville, Spain)

Barbara Merrill (University of Warwick, United Kingdom)

Marcella Milana (Aarhus University, Denmark)

Henning Salling Olesen (Roskilde University, Denmark)

\section{Scope}

'Research on the Education and Learning of Adults' aims at providing an in-depth insight on the diversity of current research on adult education in diverse teaching/learning contexts in both geographical and cultural terms in Europe. Research on adult education has been characterised by different intellectual traditions, theoretical and methodological approaches and which are still alive today in Europe from the north to the south and from the west to the east. This book series is edited by the European Society for Research on the Education of Adults (ESREA). The content of the series reflects the wide range of research activities undertaken by ESREA's members and networks such as: access, learning careers and identities; active citizenship; the professional development of adult educators; working life; the history of adult education; gender; local development and adult learning; ethnicity; older learners; adult education policies and biographical research. This book series will appeal to an international audience as it engages with current and relevant empirical research, a range of theoretical perspectives and knowledge thus stimulating debate, discussion and knowledge dissemination in the field in a democratic and heterogeneous way.

\section{Editorial Advisory Board}

Michal Bron Jr. (Södertörn Univ. College, Sweden)

Anja Heikkinen (University of Tampere, Finland)

Francoise F. Laot (University Paris-Descartes, France)

Linda Morrice (University of Sussex, United Kingdom)

Joanna Ostrouch (University of Warmia and Mazury in Olsztyn, Poland)

Angela Pilch-Ortega (Graz University, Austria)

Andreas Wallo (Linköping University, Sweden)

Georgios Zarifis (Aristotle University of Thessaloniki, Greece) 


\section{Learning across Generations in Europe}

Contemporary Issues in Older Adult Education

Edited by

Bernhard Schmidt-Hertha

University of Tübingen, Germany

Sabina Jelenc Krašovec

University of Ljubljana, Slovenia

and

Marvin Formosa

University of Malta, Malta

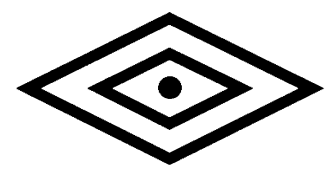

SENSE PUBLISHERS

ROTTERDAM / BOSTON / TAIPEI 
A C.I.P. record for this book is available from the Library of Congress.

ISBN 978-94-6209-900-5 (paperback)

ISBN 978-94-6209-901-2 (hardback)

ISBN 978-94-6209-902-9 (e-book)

Published by: Sense Publishers,

P.O. Box 21858, 3001 AW Rotterdam, The Netherlands

https://www.sensepublishers.com/

Printed on acid-free paper

All rights reserved @ 2014 Sense Publishers

No part of this work may be reproduced, stored in a retrieval system, or transmitted in any form or by any means, electronic, mechanical, photocopying, microfilming, recording or otherwise, without written permission from the Publisher, with the exception of any material supplied specifically for the purpose of being entered and executed on a computer system, for exclusive use by the purchaser of the work. 
This book is dedicated to all older learners who are curious and proactive in their own way of searching for knowledge and engaging in educational pursuits. 



\section{CONTENTS}

Foreword by Brian Findsen $\quad$ ix

Acknowledgements $\quad$ xiii

The European Society for Research on the Education of

Adults (ESREA) $\quad \mathrm{xV}$

1. Introduction: Older Adult Education and Intergenerational Learning 1 Bernhard Schmidt-Hertha, Sabina Jelenc Krašovec \& Marvin Formosa

\section{SECTION 1: THEORY AND POLICY ISSUES}

2. Lifelong Learning in Later Life: Policies and Practices 11 Marvin Formosa

3. Older Men's Learning and Conviviality Barry Golding

4. Education and Empowerment in Later Life

Esmeraldina Veloso \& Paula Guimarães

5. E-learning: An Opportunity for Older Persons Veronika Thalhammer

6. Older Adults as Active Learners in the Community António Fragoso

\section{SECTION 2: PARTICIPATION AND PROGRAMMES}

7. Conceptual Basis for Learning: Frameworks for Older Adult Learning

Dominique Kern

8. Temporary Exit from Employment: Possibilities for Lifelong Learning in Early Retirement

Alfredo Alfageme

9. Lifelong Learning and Skills Development in the Context of Innovation Performance: An International Comparison Tarja Tikkanen 


\section{CONTENTS}

10. Learning for Disadvantaged Seniors: Issues of Outreach, Access Provision and Delivery

Georgios K. Zarifis

11. Voluntary Work as the Seniors' Space for Learning Matgorzata Malec-Rawiński

\section{SECTION 3: INTERGENERATIONAL LEARNING}

12. Different Concepts of Generation and Their Impact on Intergenerational Learning

Bernhard Schmidt-Hertha

13. What Grows in Gardens? Perspectives on Intergenerational Learning in Urban Spaces

Barry J. Hake

14. Intergenerational Learning in Different Contexts

Sonja Kump\& Sabina Jelenc Krašovec

15. Older Adults as Active Members of Non-Governmental Organisations

Irena Žemaitaityte

16. Intergenerational Learning and Social Capital Ann-Kristin Boström

17. Conclusion: Policy Futures in Older Adult Education and Intergenerational Learning

Marvin Formosa, Sabina Jelenc Krašovec \& Bernhard Schmidt-Hertha

About the Contributors 


\section{BRIAN FINDSEN}

\section{FOREWORD}

I welcome the opportunity to provide commentary on the advent of this important book, not only from a perspective of the European context, but also in terms of its likely impact further abroad. While the content of the book addresses the growing area of interest globally in inter-generational learning, the issues have resonance in places as far away as New Zealand. Older adult learning/education is fast moving as an interdisciplinary force into territory with which adult educators and other professionals are being forced to acquire more familiarity because of ageing population structures in many countries, especially within Europe. What is less understood, and where this book provides fresh insight, is the way intergenerational learning intersects with older people's learning.

The common ground for dialogue is that of lifelong learning/education. When we look at the full range of learning opportunities open to different groups of older adults, we come to appreciate, as identified by authors in this volume, that there is considerable diversity. This diversity of conceptualisation and practice relates to informal learning contexts (e.g. families), to non-formal (as exemplified by voluntary organisation participation and non-governmental organisations) and informal (e.g. gardening circles in urban allotments). Many older adults learn more from informal and non-formal contexts but this does not exempt formal education institutions from providing equal learning opportunities to seniors. Intergenerational learning (which itself can be categorised from less to more formal) has the potential to allow marginalised groups of older people to engage in relevant learning in non-threatening contexts.

The three major strands in this book align with major pre-occupations of theorists, practitioners, researchers and policy-makers within educational gerontology. In the first section, 'Theory and policy issues', the importance of conceptualising lifelong and life-wide learning comes to the fore. While the economic imperative for lifelong learning is never far from our consciousness in neo-liberal contexts, among older adults other objectives for learning usually assume prominence (personal fulfilment; education for effective citizenship; learning for social inclusion).Throughout this book these multiple threads of lifelong learning permeate discussion, as exemplified by reference to widening participation (to more explicitly address the learning needs of older adults), how higher education (universities) structures and processes may better relate to seniors' aspirations and to the paucity of provision for people in the fourth age of learning. The underpinning notion of empowerment is nearly always underpinning this discussion, particularly because significant numbers of older persons live in poverty and tolerate poor objective living conditions. While e-learning may provide a partial answer to getting greater numbers older adults to engage in 
learning, social stratification in European societies often prevents equitable access to ICT, even if the fear factor of engaging with digital media can be overcome.

In the second section, 'Participation and programmes', several issues of high significance are debated. A major issue is that of countries' endeavouring to provide learning/education possibilities to a heterogeneous older population. Typically, those with marked prior experience in acquiring learning resources (such as middle-class adults, mainly women, in U3As) can effectively look after themselves. As identified in the Portuguese chapter, the characteristics of 'nonparticipants' point to marginalised sub-groups who struggle to gain access to education. This characterisation is transportable across many Western cultures but is most poignant when we consider what governments and (educational) institutions provide (or fail to provide) for older citizens. Despite considerable rhetoric concerning lifelong learning embodied in manifold public statements (e.g. from the European Commission) at international, national and local authority levels, actual funding and practical support is missing. Innovative ways of trying to provide more equitable resources to citizens across the life-course, as in the Temporary Exit from Employment (TEFE), are too readily dismissed. Old paradigms of life-course progression from education (schooling) to work to leisure (retirement) do not die easily and persist when logic tells us to act differently.

In the third section, 'Intergenerational Learning', the potential for learning across generations is emphasised. Discussion on the definitions of concepts such as 'generation' is very useful in that taken-for-granted ideas are challenged. Meanings of "inter-generational learning" are shown to be numerous, as are various modes (learning from each other; learning together; learning about one another). Yet definitional issues should not prevent educators and others from identifying in specific contexts the benefits of generational learning. The association of intergenerational learning with increased social capital, community engagement and increased well-being is not to be denied even though as yet these connections are somewhat tenuous. In family contexts, most of us readily appreciate the value of the informal exchange of knowledge and heightened self-esteem that arises from young and old sharing skills and information together. The need for more substantive research on what constitutes inter-generational learning and the identification of effective principles that optimise benefits, without neglecting concern for the removal of barriers, should be a priority.

The diverse range of topics covered in this European-centred volume provides a basis for further dialogue both within Europe and internationally. The interconnectedness of policy, research and practice, manifested in this work, needs to continue across the globe. From the location in which this Foreword is written (New Zealand), many of the issues identified in this edited book are immediate and urgent. While the development of a critical educational gerontology provides a useful base for further analysis, especially of examining underpinning assumptions about why, how and what older people learn, it is yet to connect with how governments treat this sub-field of education and of gerontology. Across the globe, we await more explicit connection between policy on ageing (as in 'active ageing' or 'productive ageing') and that of lifelong learning. Insights into the character of 
FOREWORD

inter-generational learning, portrayed in this new volume of articles, provide salient coverage of factors illustrated in research and practice that might convince authorities to take older adult learning/education more seriously.

\section{Brian Findsen}

Hamilton, New Zealand

10 July 2014 



\section{ACKNOWLEDGEMENTS}

We would like to thank the European Society for Research on the Education of Adults (ESREA), and in particular its steering committee, for accepting this book for the ESREA series. Our special thanks are for the editorial board of the series who gave us helpful feedback and advice.

This book is first of all a documentation of the meaningful research work that is done by the colleagues involved in the European Network on Education and Learning of Older Adults (ELOA) which has been re-launched five years ago. Almost all authors of this book are active members of ELOA, but all other ELOA members gave us invaluable inspiration for the book. Thanks to all of you!

The content of the book is based on a lot of high quality research work which is partly presented by colleagues all over Europe. Therefore, a very warm thanks goes to all authors who contributed to the book. It is always a great pleasure to work with you!

Last but not least, we would like to thank our families who always support us even if this means less quality family-time during weekends and holidays. 



\section{THE EUROPEAN SOCIETY FOR RESEARCH ON THE EDUCATION OF ADULTS (ESREA)}

ESREA is a European scientific society. It was established in 1991 to provide a European-wide forum for all researchers engaged in research on adult education and learning and to promote and disseminate theoretical and empirical research in the field. Since 1991 the landscape of adult education and learning has changed to include more diverse learning contexts at formal and informal levels. At the same time there has been a policy push by the European Union, OECD, UNESCO and national governments to promote a policy of lifelong learning. ESREA provides an important space for these changes and (re)definition of adult education and learning in relation to research, theory, policy and practice to be reflected upon and discussed. This takes place at the triennial conference, network conferences and through the publication of books and a journal.

\section{ESREA RESEARCH NETWORKS}

The major priority of ESREA is the encouragement of co-operation between active researchers in the form of thematic research networks which encourage interdisciplinary research drawing on a broad range of the social sciences. These research networks hold annual/biennial seminars and conferences for the exchange of research results and to encourage publications.

The current active ESREA networks are:

- Access, Learning Careers and Identities

- Active Democratic Citizenship and Adult Learning

- Adult Educators, Trainers and their and Professional Development

- Between Global and Local: Adult Learning and Development

- Education and Learning of Older Adults

- Gender and Adult Learning

- History of Adult Education and Training in Europe

- Interrogating transformative processes in learning: An international exchange.

- Life-history and Biographical Research

- Migration, Ethnicity, Racism and Xenophobia

- Policy Studies in Adult Education

- Working Life and Learning

\section{ESREA TRIENNIAL EUROPEAN RESEARCH CONFERENCE}

In order to encourage the widest possible forum for the exchange of ongoing research activities ESREA holds a triennial European Research Conference. The conferences have been held in Strobl (1995), Bruxelles (1998), Lisbon (2001), Wroclaw (2004), Seville (2007), Linköping (2010) and Berlin (2013) 
ESREA

\section{ESREA JOURNAL}

ESREA publishes a scientific open access journal entitled The European Journal for Research on the Education and Learning of Adults (RELA). All issues of the journal can be read at www.rela.ep.liu.se. You can also find more information about call for papers and submission procedures on this website.

\section{ESREA BOOKS}

ESREA's research networks and conferences have led to the publication of over forty books. A full list, giving details of the various publishers, and the books' availability, is on the ESREA website. ESREA's current book series is published in co-operation with Sense Publishers.

Further information on ESREA is available at www.esrea.org

Kristiina Brunila

Emilio Lucio-Villegas

Barbara Merrill

Henning Salling Olesen 


\title{
BERNHARD SCHMIDT-HERTHA, SABINA JELENC KRAŠOVEC \& MARVIN FORMOSA
}

\section{INTRODUCTION}

\author{
Older Adult Education and Intergenerational Learning
}

\section{THE STORY SO FAR}

Demographic transformations in European and other industrialised countries do not only raise important challenges in the development of ageing policies but also offer new possibilities and perspectives. Responding to the challenges of population ageing on behalf of both governments and civil society is crucial for advancing higher levels of active and successful ageing. Undoubtedly, education and learning have a key role in improving the quality of life and well-being of middle-aged and older adults as they promise to strengthen social networks and social support, influence social solidarity, whilst also fostering economic development (Albertini, 2007; Bar \& Russel, 2006; Henkin, 2007). Older adult learning also has immense potential to improve levels of productive ageing by ensuring that older workers have the necessary skills required by potential employment opportunities (Cahill et al., 2006; Chen \& Scott, 2003). Last but not least, intergenerational learning contributes to the policy areas of community cohesion, community safety, health, and well-being by (i) bringing together different generations through meaningful activities and interactions, (ii) increasing understanding between generations, breaking down stereotypes and providing positive role models, and (iii) preventing anti-social behaviour and challenge perceptions (Schuller, 2010).

Questions, however, remain on issues relating to social inclusion, participation, and civic engagement in relation to late-life learning. The research in Europe demonstrates that older adults are a very diverse population, having different learning, social needs and abilities, and that only small percentages of older population participate in formal and non-formal learning avenues. Findsen and Formosa (2011) describe those who participate in older adult and community education are generally those who have attended school more than an average amount of time and passed formal qualifications, women (although men tend to be in the majority in more vocationally oriented courses), persons aged 60 to 75 years, white ethnic groups, affluent members of the retired class, and people with strong white-collar occupational backgrounds. At the same time, it is often wrongly assumed that any kind of education is emancipatory and results in the improvement of the quality of life of the older adults, and that most education for the older adults is in their interest when - of course - this is not the case (Formosa, 2010). Finally, 
questions remain the relative lack of discussion on the geragogical contexts of latelife learning, as research on learning aims (Schmidt, 2007, 2010), and evaluation of educational programs for older adults (Czaja et al., 2012; Leong \& Liu, 2011; Truluck et al., 2010) continues to provide evidence in favour of age-friendly frameworks of elder learning to meet the needs and interests of older target groups.

Following the European Year of Active Ageing and Solidarity between Generations in 2012, one witnessed a lot of discussions on age-related policy, theory and practice. Many conferences have been organised on the learning and education of older people, gerontology and ageing in general, but also upon intergenerational learning in different contexts. The necessity of strengthening intergenerational solidarity was especially emphasised since the ageing of population not only creates conflicts regarding distribution of economic sources (Collard, 2001; Gamliel et al., 2007), but may also lead to intergenerational conflict. Generational gap is very often defined as a cultural gulf between generations. In this respect, intergenerational learning and education is understood to have immense potential for overcoming this gap and reaching new forms of solidarity and trust between younger and older generations (Kaplan, 2001; Garstka et al., 2005; Campbell, 2009). For educational systems this not only means to provide learning opportunities for older adults during their employment years and immediately after retirement, but also to encourage and support participation of older adults in other areas including residential and nursing homes. Such developments also imply the development of new opportunities for cooperation between generations, and the intergenerational exchange of knowledge, opinions and perspectives. Reflections of policy makers, practitioners, and researchers on intergenerational learning point to a very heterogeneous and ill-defined phenomenon. When every kind of interaction between different age cohorts is called intergenerational learning, almost everything can be summarised under that label. This adulteration of the concept 'intergenerational learning' is caused by different meanings of the term 'generation', the mix of very different forms of formal, non-formal and informal learning, as well as by a lack of clarity what 'inter'-generational means. Moreover, the exchange between grandparents and grandchildren within the family (Gadsden \& Hall, 1996), groups of learners with different age in an adult education program (Krout et al., 2010), and initiatives that bring together children and habitants of senior residents (Ginnane, 1981), are all related to intergenerational learning (Hatton-Yeo, 2007).

The aim of this book is to give an overview on the different concepts, ideas, and meanings, related to older adults' education, learning and intergenerational learning through theoretical standpoints, empirical research, and policy directions. This research area in older adult education has expanded immensely in recent years since it raised questions that are connected to a rapidly ageing society in very turbulent times of economic and social changes in Europe. This book will provide the basis for more in-depth analysis of the understandings and interpretations of theoretical concepts on education and learning in later-life, 
rethinking on development of different approaches for education of older adults, as well as diverse research and evaluation of different forms of older adults' education and learning. The chapters will also address more differentiated discussion on the diverse phenomena labelled as intergenerational learning, linking theoretical conceptions related to learning in later life and intergenerational relationships. It will also hopefully provide some impulses for the development of further theoretical research on intergenerational learning, a possibility which is missing so far. Assuming that strengthening the development of theoretical concepts will influence and promote empirical research, the book deals with different definitions and forms of appearance of intergenerational learning programmes, which are diverse due to variety of contexts, included learning groups and non-reconciliated understandings (Kaplan, 2001, 2002).

Adult education is always related to diversity by being intimately interested with the heterogeneity of learners, diverse learning environments, and varying organizational and political frameworks learning processes. Looking at participation rates in adult education programmes as a central indicator for lifelong learning, it seems obvious that age matters for learning activities (Desjardins et al., 2006). However, most of the relevant data is cross sectional and does not give the opportunity to separate age effects from cohort effects. In other words, cross sectional data does not provide an answer if differences between age groups are related to ageing processes or to generational shifts. Different theoretical approaches - also within the discussion on intergenerational learning - provide arguments for both. Qualitative research findings can therefore add more in-depth insight to the problems of participation of different groups of older adults in different social contexts and situations.

Life course theories coming from developmental psychology, gerontology and sociology offer good rationales for changes in learning and educational behaviour as people get older (Findsen \& Formosa, 2011). The sociology of education also offer additional explanation on age differences in learning and education as a result of changing life circumstances and influence of different social environments in different phases of life (Strobel et al., 2012; Alwin McCammon, 2003; Putney \& Bengtson, 2003). On one hand, generational identities and age-related needs can be forms of diversity that adult education programs have to address. On the other hand, differences between age-groups and generations can be seen as central catalyst for educational processes, when confrontation and mutual participation of people with different experiences and different living conditions becomes the centre of learning (Cruz \& Snyder, 2009). Adult educators then have to know how to make use of heterogeneity within the learning group and to understand it as a resource rather as a challenge (Franz, 2010). At the same time, there may be topics, learning aims and target groups which can be better addressed in homogenous learning groups, considering specific needs and interests of certain age groups. And, finally, learning groups are always a part of the wider social environment or community and they should encounter the learning needs, connected to challenges and problems existent in this particular social context. Adult educators should be 
aware of importance to give social meaning to learning and educational activities and therefore include all the participants in planning educational goals and their achievement.

To learn more about the learning needs of tomorrows' older adults - in ageheterogeneous or homogeneous groups - more research is needed particularly looking at the meaning of age and processes of socialisation. Both are related to cultural, social and historical conditions of growing up, initial education, and vocational careers. This book will offer some recent research work and some new insights related to learning in late life and intergenerational learning from different European perspectives. Recent decades witnessed an unprecedented amount of research focusing on learning in later life and intergenerational learning. Whilst this is to be welcomed, many research questions remain unanswered. Learning across generations will provide some answers to prevailing dilemmas by documents emerging theoretical approaches and empirical studies that focus upon the differences in learning needs and educational interests of different generations and different age groups, educational programmes in formal and non-formal learning opportunities for older persons, as well as the current state of intergenerational research. The possibilities of older people to fulfil their learning needs and strengthen social networks with learning and education are central preoccupations of learning across generations.

\section{CONTENT AND STRUCTURE}

Learning across generations in Europe: Contemporary issues in older adult education is divided in three sections. The first section, 'Theory and policy issues', includes five chapters. In Chapter 2, 'Lifelong learning in later life: Policies and practices', Marvin Formosa provides an overview on European policies and practices in the field of learning in later life. It indicates the extent that educational practices have been developed when relating to older learners. From a critical perspective, one finds deficits and lacunae in both policy and practice which hinder a holistic approach towards learning activities in later life. The subsequent chapter by Barry Golding, 'Older men's learning and conviviality', presents an innovative strategy to involve older men further into learning processes, who otherwise would not so much participate in learning ventures. In Chapter 4, 'Education and empowerment in later life', Esmeraldina Veloso and Paula Guimarães discuss the meaning of learning and education for older adults as a human right and as an irreducible task for the civil society. The authors illustrate this possible development for older adult learning with various examples from France and Portugal. In Chapter 5, 'E-learning: An opportunity for older persons', Veronika Thalhammer presents a range of empirical insights in the ways older adults explore the digital world and how it effects their learning. The context, in which mass media are applied, is nowadays multi-faceted and provide various opportunities for lessening the isolation of older adults in their communities. This issue is picked up by the final chapter in this section, 'Older adults as active learners in the community', in which António Fragoso highlights 
how the inclusion of older adults in the community may provide significant benefits for all (older adults and other community members), and how - through a case-study of a fishing club in Portugal - it leads to the development of informal learning processes.

The book's second section, 'Participation and programmes', includes another five chapters. In Chapter 7, 'Conceptual bases for learning: Frameworks for older adult learning', Dominique Kern discusses the didactical and organisational aspects of learning arrangements for older adults. Without neglecting the diversity of older adults, he argues how the special circumstances and developmental tasks in later life can inspire conceptual ideas on how to arrange elder learning environments. In Chapter 8, 'Temporary exit from employment: Possibilities for learning in early retirement', Alfredo Alfageme argues for a more flexible pathway into retirement that supports a new work-lifebalance in older age instead of an overnight transition from work to retirement. His research underlines the meaning of learning as a facilitator to design new ways of active ageing. In Chapter 9, 'Lifelong learning and skills development in the context of innovative performance', Tarja Tikkanen analyses the relationship of explicit and experiential knowledge and their contribution to vocational competences in later life. Even if experience and formally gained knowledge is associated with age, there are many plausible arguments for more age-neutral 'human resource development'. In Chapter 10, 'Learning for disadvantaged seniors: Issues of outreach, access provision and delivery', George Zarifis underlines how retirees are not only at risk of social exclusion but are also massively affected by the financial crisis. Indeed, participation in lifelong learning is only one area where older adults belong to the marginalised groups as can be learned from a European research project. The potential of civic engagement, for elder learning, is tackled by the final chapter in this section, authored by Małgorzata Malec-Rawiński, and titled 'Voluntary work as the seniors' space for learning'. It highlights how the potential of older adults to engage themselves in civil society is - at least in Poland but probably in many other countries too largely underdeveloped.

The book's third and final section, 'Intergenerational learning', also includes five chapters, tackling such dilemmas as: do different generations of adult learners need different educational offers? - and, what is the role of adult education looking at intergenerational exchange of knowledge? In Chapter 12, 'Different concepts of generation and their impact on intergenerational learning', Bernhard SchmidtHertha stresses the lack of a theory on intergenerational learning, which highlights the arbitrariness in the way the term is used in research, practice, and policy. A categorization of different ideas for intergenerational learning is consequently proposed. In Chapter 13, 'What grows in gardens? Perspectives on intergenerational learning in urban spaces', Barry J. Hake discusses the various processes involved in the art of gardening in urban spaces, where gardening is posited as an example for opportunities to learn within community settings. Chapter 14, 'Intergenerational learning in different contexts', looks at a broader range of intergenerational learning contexts. The authors, Sonja Kump and 
Sabina Jelenc Krašovec discuss those meanings and effects of intergenerational learning that go beyond the cognitive level. The potential of intergenerational learning within non-governmental organisations is tackled in Chapter 15, 'Older adults as active members of non-governmental organisations', as Irena Žemaitaityte discusses how voluntary organisations offer opportunities for older adults to bring in their experiences and competencies for social and learning purposes. In the final chapter, 'Intergenerational learning and social capital', AnnKristin Boström underlines the impact of intergenerational learning on social capital in diverse contexts and with a more theoretically inspired approach, but grounded on empirical evidence. Following the meaning of intergenerational learning for social cohesion, she offers a model for designing intergenerational learning environments.

In a final conclusion, the editors attempt to bring together the most significant results and argumentation lines of the different chapters. This chapter elucidates on some of the most pressing challenges for educational practice, policy and research related to the learning of older adults and intergenerational learning. Although this book will not be a definite answer towards the meeting of such a range of challenges and dilemmas, it surely provides an overview of the most recent theoretical strands and empirical data that is available so far. In doing so, Learning across generations in Europe: Contemporary issues in older adult education acts as a catalyst for the further development of elder and intergenerational learning.

\section{REFERENCES}

Albertini, M. (2007). Le reti di sostegno economico e di cura degli anziani poveri. Il caso italiano e uno sguardo all'Europa. In A. Brandolini \& C. Saraceno (Eds.), Povertà e benessere. Una geografia delle disuguaglianze in Italia (pp. 351-376). Bologna: il Mulino.

Alwin, D. F., \& McCammon, R. J. (2003). Generations, Cohorts and Social Change. In J. T. Mortimer \& M. J. Shanahan (Eds.), Handbook of the life course (pp. 23-49). New York, Boston, Dordrecht, London, Moscow: Kluwer Academic.

Barr, F. M., \& Russell, C. A. (2006). Social capital - A potential tool for analysis of the relationship between ageing individuals and their social environment. Ageing International, 3, 203216.

Cahill, K. E., Giandrea, M. D., \& Quinn, J. F. (2006). Retirement patterns from career employment. The Gerontologist, 46(4), 514-523.

Campbell, A. L. (2009). Is the economic crisis driving wedges between young and old? Rich and poor? Generations - Journal of the American Society on Ageing, 33(3), 47-53.

Chen, Y.-P., \& Scott, J. C. (2003). Gradual retirement: An additional option in work and retirement. North American Actuarial Journal, 7(3), 62-74.

Collard, D. (2001). The generational bargain. International Journal of Social Welfare, 10 (1), 54-65.

Cruz, F. M. F., \& Snider S. L. (2009). Storying with Technology: an approach to connect children and adults using the new technology and media landscape. Contemporary Issues in Early Childhood, 10(4), 378-388.

Czaja, S. J., Lee, C. C., Branham, J., \& Remis, P. (2012). Oasis connections: Results from an evaluation study. Gerontologist, 52(5), 712-721. 
Desjardins, R., Rubenson, K., \& Milana, M. (2006). Unequal chances to participate in adult learning: International perspectives. Paris: UNESCO.

Findsen, B., \& Formosa, M. (2011). Lifelong learning in later life: A handbook on older adult learning. Rotterdam: Sense.

Formosa, M. (2010). Older adult learning in Malta: Towards a policy agenda. Mediterranean Journal of Educational Studies, 15(1), 61-85.

Franz, J. (2010). Social cohesion and intergenerational learning arrangements. In Online Documentation of the Conference The Impact of Cultural and Citizenship Education on Social Cohesion, Vilnius, December 2009. Published on the website of NECE. Accessed 1/6/01 from: www.bpb.de/files/XR5A1H.pdf.

Gadsden, V. L., \& Hall, M. (1996). Intergenerational learning: A review of the literature. Philadelphia: NCOFF.

Gamliel T., Reichental, Y., \& Eyal, N. (2007). Intergenerational education encounters: Part 2: Counselling implications of the model. Educational Gerontology, 33(2), 145-164.

Garstka, T. A., Hummert, L. M., \& Branscombe, N. R. (2005). Perceiving age discrimination in response to intergenerational inequity. Journal of Social Issues, 61(2), 321-342.

Ginnane, P. (1981). Intergenerational education: Young and old learning together. Washington, DC: ERIC.

Hatton-Yeo, A. (2007). Intergenerational practice: Active participation across the generations. Stoke on Trent: Beth Johnson Foundation.

Henkin, N. Z. (2007). Communities for all ages: A practical model. In M. Sánchez, D. M. Butts, A. Hatton-Yeo, N. A. Henkin, S. E. Jarrott, M. S. Kaplan, A. Martínez, S. Newman, S. Pinazo, J. Sáez, \& A.P. Weintraub (Eds.), Intergenerational programmes. Towards a society for all ages (pp. 147166). Barcelona: The "la Caixa" Foundation.

Kaplan, M. S. (2001). School-based intergenerational programs. Hamburg: Unesco Institut for Education.

Kaplan, M. S. (2002). Intergenerational programs in schools: Considerations of form and function. International Review of Education, 48(5), 305-334.

Krout, J. A., Bergman, E., Bianconi, P., Caldwell, K., Dorsey, J., Durnford, S., \& Taves, J. V. (2010). Intergenerational service learning with elders: Multidisciplinary activities and outcomes. Gerontology \& Geriatrics Education, 31(1), 55-74.

Leung, D. S. Y., \& Liu, B. C. P. (2011). Lifelong education, quality of life and self-efficacy of Chinese older adults. Educational Gerontology, 37(11), 967-981.

Putney, N. M., \& Bengtson, V. L. (2003). Intergenerational relations in changing times. In J. T. Mortimer \& M. J. Shanahan (Eds.), Handbook of the life course (pp. 149-164). New York: Kluwer Academic/Plenum.

Schmidt, B. (2007). Older employee behaviour and interest in continuing education. Journal of Adult and Continuing Education, 13(2), 156-174.

Schmidt, B. (2010). Educational goals and motivation of older workers. In S. Bohlinger (Ed.), Working and learning at old age. Theory and evidence in an emerging European field of research (pp. 127136). Göttingen: Cuvillier.

Schuller, T. (2010). Learning through life: The implications for learning in later life of the NIACE Inquiry. International Journal of Education and Ageing, 1(1), 41-51.

Strobel, C., Schmidt-Hertha, B., \& Gnahs, D. (2011). Bildungsbiografische und soziale Bedingungen des Lernens in der Nacherwerbsphase. Magazin erwachsenenbildung.at, (13), 01-2 - 19-4. Accessed 9/24/14 from: http://www.erwachsenenbildung.at/magazin/11-13/meb11-13.pdf.

Truluck, J., Kim, Y. S., \& Valentine, T. (2010). Participation patterns and learning selections of senior members of a learning in retirement organization. Adult Learning, 21(1-2), 31-36. 
SCHMIDT-HERTHA, JELENC KRAŠOVEC \& FORMOSA

Bernhard Schmidt-Hertha

Institute of Education

University of Tuebingen

Germany

Sabina Jelenc Krašovec

Faculty of Arts

University of Ljubljana

Slovenia

Marvin Formosa

Gerontology Unit, Faculty for Social Wellbeing

University of Malta

Malta 
SECTION 1

THEORY AND POLICY ISSUES 



\title{
MARVIN FORMOSA
}

\section{LIFELONG LEARNING IN LATER LIFE}

\author{
Policies and Practices
}

\section{INTRODUCTION}

Lifelong learning in later life has emerged as a decisive element in strategies advocating positive and active ageing (Formosa, 2012a). Suffice to remark that older adult learning has gained a constant presence in policy documents, ranging from international declarations such as the United Nations' (2002) Madrid International Plan of Action on Ageing and the European Commission's (2006) Adult Learning: It's never late to learn, to national statements such as Malta's National Strategic Policy for Active Ageing: Malta 2014-2020 (Parliamentary Secretariat for Rights of Persons with Disability and Active Ageing, 2013). It is believed that older adult learning allows citizens to remain healthy, independent and socially included as long as possible. As Schuller (2010) underlines, elderlearning is a necessary lubricant to keep a dynamo of opportunity and activity in the lives of older adults. This chapter commences by presenting an overview of older adult learning, followed by a commentary of European policy on late-life learning. Whilst the third section discusses what makes good practice in older adult education, the final section forwards possible future policies for late-life learning.

\section{OLDER ADULT LEARNING}

Older adult learning refers to the process in which older adults, "individually and in association with others, engage in direct encounter and then purposefully reflect upon, validate, transform, give personal meaning to and seek to integrate their ways of knowing" (Weil \& McGill, cited in Mercken, 2010: 9). The key catalyst responsible for the rising demand and success of older adult learning constitutes the development of the 'third age' (Findsen \& Formosa, 2011). The term was first born and conceived in the 1950s to counteract the stereotype of later life as a short period which is plagued by illness, invalidity, and in most cases, poverty. The 'third age' refers to a specific socio-demographic trend within population ageing. It alludes to how the combination of increased longevity and other social factors ranging from earlier retirement, improving health status, establishment of the welfare institutions of retirement and pensions schemes, to more positive values and beliefs towards older persons - have opened up what could be loosely termed as a new phase in life, as the result of which persons spend a considerable amount of time in relative active years following exit from work. In such a scenario, older adult learning provides the opportunity to explore learning goals that people at 
earlier stages of the life course are often too busy to pursue, such as developing a reflective mode of thinking, contemplating the meaning of life, coming to terms with one's past as a preparation for death, and the quest for self-fulfilment and spiritual advancement. Russell (2008), for instance, painted a picture of third agers as facing a temporal kind of anxiety - that is, having a limited number of years left on one hand and a longer period of retirement on the other. She argues that this sets in a tension in their daily lives which induces them to search for and participate actively in meaningful learning projects. Similarly, Hodkinson and colleagues (2008: 179) claimed that the third age is characterized by an ongoing type of learning - that of becoming. Far from simply acquiring commodities such as skills, knowledge, or understanding, learning provides retirees with the opportunity to undergo a continuous process of personal construction and reconstruction.

Comparative data on participation rates are sporadic, and the few that exist tend to be 'unreliable' and 'not comparable' as they include different definitions of 'non-formal' and 'informal' learning (Percy \& Frank, 2011). Yet, a literature review of the literature elicits three persistent findings. First, a lower percentage of elder learners compared to younger peers, with a sharp decline of participation as people reached their seventieth decade. In the United Kingdom, only one in five over 50s are 'learners', compared to two in five of the adult population, with the proportion falling to only 7 per cent of those aged 75 and over (McNair, 2012). On the other side of the Atlantic, most further education in Canada remains joboriented, so that further education drops off rapidly to around 15 per cent or less of those over 65 (Livingstone \& Raykov, 2013). However, the good news is that older adults spend nearly as much time on informal learning as middle-aged adults (Formosa, 2012b). Various propositions have been put forward to explain why participation declines with age, ranging from situational barriers (obstacles relating to the unique circumstances of later life), institutional barriers (unintended barriers that exclude subaltern and voluntary elders), informational (failure of agencies to communicate what learning are available), to psychosocial barriers (attitudinal beliefs and perceptions that inhibit older persons' participation).

Second, typical learners are middle-class women so that the working classes, older men, and ethnic minorities are highly underrepresented. For instance, Findsen (2005) pointed out that given the multi-cultural environment of Australia and New Zealand, one would reasonably expect to see at least some Asian faces, plus those of Maori and Pasifika people, engaged in older adult learning. This is, however, not the case and memberships are heavily represented by members from the Anglo-Saxon community. Moreover, whilst most surveys on older adult learning uncover a positive women to men ratio - 3:1 in the United Kingdom and Malta (Midwinter, 1996; National Statistics Office, 2009), 4:1 percent in Australia (Hebestreit, 2006), and 2.5:1 percent in Spain (Alfageme, 2007) to mention some (Formosa, 2014) - the elitist character of some programmes (especially the University of the Third Age) is now well-documented (Formosa, 2000, 2007, 2012c). Indeed, although most programmes offer no hindrances to membership, many tend to pander "to the cultural pretentious of an aged bourgeoisie who had already learned to play the system" (Morris, 1984: 136). 
And finally, how contemporary trends in older adult learning are experiencing significant changes. Taking the United Kingdom again as a case in point, while the proportion of people aged 50 and over who report that they are engaged in learning has not changed since 2005, the numbers learning at college or university have halved (from 21 per cent to 9 per cent in colleges and from 14 per cent to 8 per cent in universities), while the numbers learning online and independently have risen (McNair, 2002). Although the proportion of older people learning about 'computing' registered a dramatic drop, from over 40 per cent in 2005 to just 17 per cent in 2012, the number of older people using computers for learning increased, in that 12 per cent of those aged 50 and over are now 'learning online'. The same trend was documented with respect to those reporting a preference to engage in informal learning, in that 16 per cent of people aged 50 and over reported to be learning 'independently on my own', and a further 9 per cent 'independently with others'. It is noteworthy that for persons aged 75 and over the former figure rises to nearly 30 per cent of learners aged 75 and over, while the latter rises to 14 per cent (ibid.).

\section{POLICY AND OLDER ADULT LEARNING}

In recent years it has become virtually impossible to locate a policy document issued by the European Commission (EC) that makes no reference to lifelong learning. The European Union (EU) regards continuous learning through life as a comprehensive strategy to meet the requirements for a Single European Market and address the repercussions of increasing structural unemployment. Cognizant of the ageing of European society - due to falling birth rates, shrinking family sizes, fewer numbers of young people in the labour market, and increasing life expectancies - the EC $(2006,2007)$ issued policy directives on lifelong learning also advised formal and non-formal learning providers of education to plan and implement further educational opportunities for older adults. Indeed, the EU considers late-life learning as a positive investment on the basis that not only it engenders positive returns of economic growth but also improves the quality of life and social development of older persons.

Following the declaration of 1996 as the European Year of Lifelong Learning, the EC published vital policy documents on lifelong learning. Key publications include Memorandum on lifelong learning (2000) and Making a European area of lifelong learning a reality (2001: 33 ) where lifelong learning was defined as "all learning activities undertaken throughout life with the aim of improving knowledge, skills and competences within a personal, civic, social and/or employment related perspective". Moreover, in June 2002 the European Council of Heads of State and Governments adopted a Resolution on lifelong learning, as the guiding principle for the reform of education and training in the member states, which argued that lifelong learning is an "indispensable means for promoting social cohesion, active citizenship, personal and professional fulfilment, adaptability and employability" (Commission of the European Communities, 2002: 1). Moreover, it was stated that lifelong learning "should enable all persons to 
acquire the necessary knowledge to take part as active citizens in the knowledge society and the labour market" (ibid.).

Despite such promising developments, older persons were a late entry in policy documents as it was only in 2006 - some eleven years after the first policy document - that late-life learning was first mentioned. Although the argument remained entrenched in an employment perspective, in that it was posited that lifelong learning and access to training must provide older workers with the necessary skills to adapt to changes on the employment market remained constant, it was positive to note that Adult Learning: It is never too late to learn (2006) and Action plan on adult learning (2007) attempted at developing a more holistic approach to older adult learning. Stressing that the growing numbers of retirees in Europe should be regarded as a potential source of educators and trainers for adult learning, the former posited two objectives for lifelong learning as far as older adults are concerned:

[1] to ensure a longer working life, there is a need for up-skilling and increasing lifelong learning opportunities for older workers ... [2] an expansion of learning provision for retired ... the Commission invites universities to be more open to providing courses for students at a later stage of their life cycle. (EC, 2006: 8-9)

The Action Plan on Adult Learning (EC, 2007) reiterated the assumption that in a 'knowledge-based' and 'ageing' society, access to lifelong learning is a condition for both economic growth and social cohesion. However, despite calling upon Member States to ensure sufficient investment in the education of older people, it is disappointing that the document does not address the issue of late-life learning in any specific detail. As the following excerpt shows, the directive seeks to locate one solution for all subaltern citizens:

This Action Plan focuses on those who are disadvantaged because of their low literacy levels, inadequate work skills and/or skills for successful integration into society ... these could include migrants, older people, women or persons with a disability. (EC, 2007: 3)

Although one welcomes the increasing attention levelled to older adults in current lifelong learning policies, literature highlights three crucial lacunae in such expositions (Formosa, 2012a). First, a neo-liberal construction of later life where 'public issues' are projected as 'private troubles'. It is unrealistic to expect older persons to solve the contemporary problems linked with retirement when such issues surfaced only as the result of wider and structural predicaments. Hence, rationales for late-life learning remain incomplete unless they are framed in terms of a discussion of appropriate provision on behalf of the state for both active and excluded elders. This is because irrespective of older persons' interests and yearning for learning opportunities, structural circumstances continue to impact greatly on the extent of participation in older adult learning. A general disinterest to participate in learning activities on behalf of non-typical learners does not suffice as a complete justification for their invisibility in learning programmes. 
Second, constraining productive ageing solely to the sphere of paid employment. Albeit the goals of lifelong learning as premised by the European Commission also include inclusion, active citizenship, and personal development, nevertheless, the discourse linking 'learning' and 'later life' is biased towards the economic realm. Human experience is surrendered to the controls of the market, so that any notion of meaning detached from 'work' and not defined according to capitalist logic simply disappears. This stance is not surprising considering that from the very beginning the EC (2001) posited the need to expand lifelong education and learning in terms of the 'competitive advantage' that is 'increasingly dependent on investment in human capital', and on knowledge and competences becoming a 'powerful engine for economic growth'. And finally, policies' exclusion of older persons located in the fourth age. Even at a relatively young age, many older adults experience complications from strokes, diabetes, and neurological diseases. The range of cognitive limitations experienced in later life is substantial with, for instance, 9.95 million older adults suffering from dementia in Europe (Alzheimer Disease International, 2010). Indeed, some 8 per cent of persons aged over 65 in the European Union reside in long-term care settings (Rodrigues et al., 2012). It follows that, for lifelong learning to be really 'lifelong', learning opportunities should also be provided to occupants of residential and nursing homes, whilst also not overlook the learning needs and interest of frail elders whose mobility, sight, and/or hearing impairments restricts them from leaving their homes.

\section{GOOD PRACTICE IN OLDER ADULT LEARNING}

Following Mercken (2010), good practice in older adult learning is achieved by the adoption of four key principles - namely, empowerment, competence development, social participation, and integration - and the extent to which these principles are implemented in the learning process. In recent times, one notes the emergence and development of an alternative, optimistic, view of ageing - one that sees population ageing as an accomplishment, and which mitigates against the stereotypical assumption that older persons are generally dependent and in need of care. However, the establishment of a really 'active ageing' society can only be achieved if policy develops appropriate channels for social participation and involvement. Education, without doubt, is a key catalyst in this respect, and has immeasurable potential to help increase senior citizens' ability to do things for themselves. In other words, older adult education and learning programmes can act as vehicles for higher levels of social and personal transformation:

When one learns something doors are opened and new possibilities present themselves. Teaching someone to use the Internet, for example, is more than simply passing on a skill. The ability to use the Internet empowers the student by giving him or her easy access to information ... increases their selfconfidence, reinforces their autonomy, helps them to remain active as long as possible ... (Mercken, 2010: 54) 
Although competence development is probably the most accepted goal of all forms of education, this is not always the case in older adult learning. This stems from the conjecture that older persons do not need new skills or knowledge, or that they will have no opportunity to use their new competencies, which is the chief reason why older workers are given less training opportunities when compared to younger peers. However, this presumption overlooks that learning is a sine qua non in a late modern society since, in order to keep up with all emergent developments, people whatever their age - need to engage in constant learning. On a more positive level, social participation is one of the most visible elements of older adult learning, as many programme organisers are well aware of the potential of learning to improve community development and social cohesion, as well as international solidarity. Finally, the principle of inclusion promotes the idea that older persons should not be handled as a separate group but, instead, should be integrated in the community whilst, of course, ensuring that their specific needs and interests are met.

During the last decades, many programmes in older adult learning have proven their success by becoming very popular with older learners (Merchen, 2001). Most successful activities are those which offer learning opportunities that are 'for older people by older people', programmes that actively encourage senior citizens' involvement. These range from Universities of the Third Age based upon the British model, pre-retirement learning programme in the Netherlands and Ireland, study circles, endeavours promoting active ageing through learning, and projects appointing senior citizens as experts. For instance, the 'Chitalista' of Bulgaria are a specific type of cultural and educational institutions which offer a wide range of educational activities and courses ranging from concerts and films, to foreign languages and music appreciation classes. Another promising venture is KAPI, an acronym for Kentron Anikiti Prosthea or Open Centres for the Elderly. There are approximately 300 of these community centres for people above the age of 60 in Greece, most of them in Athens:

Although competence development is probably the most accepted goal of all forms Centre programmes vary depending on the interest of the members. Each centre also has a planning council supervised by the director. The council meets periodically to establish programmes, arrange financing, and publicise the programmes through a newsletter published by members. Generally, the programmes are social, educational and recreational in nature. (Mercken, 2010: 73)

Another successful programme is the Universities for Older People in Italy, numbering approximately 1,000 centres, and which provide learning programmes without any forms of certification. The most popular courses are literacy and language courses, with the most attended being those about ceramics, restoration, painting, sculpture, mosaics, glasswork, and arts in general. The Dutch Senior Citizen's Association are also noteworthy. Besides acting as lobbyists for older people, the associations also develop a wide range of cultural, sport and recreational activities and services for their members, including non-formal education (Mercken, 2010). At the same time, one notes a number of projects for 
older learners living in rural communities. For instance, the Department of Continuing Education at Lancaster University operated an innovative Learning from Home programme that enabled groups of adults, many of whom were older people living in rural areas, to engage in learning through telephone conferencing (Withnall, 2010). Another success story is Stories of Our Age - coordinated by the Workers Educational Association Northern Ireland and Age Northern Ireland (2011) - which sought to provide older people living rurally with an opportunity of having their voices heard on issues affecting them as they grew older, and to offer them the chance to develop some new skills using digital technology.

The above programmes demonstrate that older adult learning should be credited for providing an opportunity for older adults to participate in lifelong learning, and therefore, contributing strongly towards the ongoing construction of societies where people age positively, and providing opportunities to a sector of the population that is generally left out in the cold as far as learning is concerned. Latelife learning also militates against the widespread stereotypes of older persons as a needy and dependent group, as passive takers and recipients of pensions and welfare services. Admittedly, at present one locates no rigorous research programme investigating the relationship between older adult learning on one hand, and improvement in physical and cognitive well-being on the other. It remains, however, that there are many valid and reliable studies showing how continued mental stimulation in later life aids learners to, at least, maintain their physical and cognitive health status (Cohen, 2006; National Seniors Australia, 2010). Moreover, Wrosch and Schulz's (2008) findings that older adults who were proactive and persistent in countering health problems experienced greater physical and mental health benefits augurs well, since most elder-learning programmes offer various courses on health promotion and illness prevention.

\section{FUTURE POLICY DIRECTIONS}

In view of the fact that older adult learning is fastest growing category of lifelong learning, there is an urgent need for more intensive policy on late-life learning. It is augured that policy directives are guided by a rational that reinstates lifelong learning in the values of social levelling, social cohesion, and social justice (Faure, 1972). Only so will it become possible for late-life education to prioritise the 'democratic-citizen' over the 'future worker-citizen' as the prime asset of postindustrial societies (Lister, 2003). National policies on lifelong learning that tackle the issue of late-life learning should be promulgated so as to respond to older adults that remain educationally excluded and socially disadvantaged. At the same time, providers must think out of the box so that late-life learning initiatives attract older adults with working class backgrounds, ethnic minorities, older men, elders in living in rural regions, and housebound elders. There must also be serious attempts in outreach work which facilitate learning opportunities outside formal settings with older adults who could or would not usually participate in traditional formally organised provision, with the teaching of ICT and e-learning strategies comprising a central priority to such an effect. 
At a community level, local authorities should take on a more explicit role and responsibility in the planning, coordination and financing of late-life learning. In partnership with third sector agencies, local authorities should take the role of learning hubs that bring all the "providers (public, private, and voluntary together) together, to coordinate resources ... and promote learning among older people" (McNair, 2009: 17). Moreover, there should be an awareness that the educational system that spends some 18 years, and substantial financial capital, to prepare citizens for the world of work, but simply a couple of afternoons to leave it, is clearly biased against older persons. Society has an obligation towards its citizens to provide them with learning initiative that help them plan for their third and fourth ages. It is noteworthy that a really democratic pre-retirement education is not simply instruction about the formalities surrounding pensions, the drawing of wills, and health. It is one which also includes a discussion of psychological and social strategies that lead older adults to improve their quality of life. Moreover, local authorities should recognise the empowering benefits of coordinating educational activities that link older adults with children, teenagers, adults, and even much older peers and coordinate educational initiatives that increase cooperation, interaction, or exchange between different generations.

The amalgamation of state and community efforts in improving the state of older adult learning in the European context - whether in formal, non-formal or informal avenues - lead to the following policy priorities for the future:

Widening participation. Responding to older adults that remain educationally and socially disadvantaged necessitates a 'widening participation' agenda. Providers must think out of the box so that late-life learning initiatives attract older adults with working class backgrounds, older men, elders in living in rural regions, and housebound elders. There must be serious attempts in outreach work to facilitate learning opportunities outside formal settings with older adults who could or would not usually participate in traditional formally organised provision. Without doubt, the teaching of ICT and e-learning strategies comprise a central priority on a 'widening participation' agenda.

Higher education. There is a need for the higher education sector to play a key role in encouraging new types of adult learning through all phases of the life course. In addition to employment-related programmes that support older people moving from full-time employment to various forms of work, higher education must also provide 'personal development' programmes which identify new types of courses and markets among a diverse and segmented post-50s market, and 'health and social care' programmes orientated to professionals working with older people that vary from foundation degrees through to modules for continuing professional development (Phillipson \& Ogg, 2010).

Productive ageing. There is a need for learning initiatives for employment, both for those still in or seeking paid work, while latching upon European Union-funded programmes. Emphasis must go beyond simply the provision of courses leading to formal qualification, and also include initiatives that update skills and knowledge, and adopt previous experience to new contexts (McNair, 2009). Programmes must 
be sensitive to gender differences in or finding work, as well as respect the choice of those who may still want to embrace a 'culture of retirement' even if it means a 'trade-off' with a lower standard of living.

Pre-retirement education. The educational system that spends some 18 years, and substantial financial capital, to prepare citizens for the world of work, but simply a couple of afternoons to leave it, is clearly biased against older persons. Society has an obligation toward its citizens to provide them with learning initiative that help them plan for their third and fourth ages. It is noteworthy that a really democratic pre-retirement education is not simply instruction about the formalities surrounding pensions, the drawing of wills, and health. It is one which also includes a discussion of psychological and social strategies that lead older adults to improve their quality of life.

Fourth age learning. Learning initiatives should be made available to family relatives and volunteers involved in the care of older persons. Such programmes are to focus on the dynamics of sensing the feeling of older persons and perspectives, taking an interest in caring outcomes, empowering older adults' development and strengthening their abilities, cultivating opportunities for diverse people, and anticipating, recognising, and meeting the needs of the person under care. At the same time, there is an urgent need to support learning initiatives in care homes so that all older persons, even those suffering from confusion or dementia, have an opportunity to participate in learning opportunities.

\section{CONCLUSION}

As European's population continues to witness higher numbers of older persons, the development of older adult learning will have far more serious implications to establish active ageing societies. Indeed, late-life learning enables older people to adjust to rapid social changes, as well as helping them to achieve higher levels of social and personal empowerment. Older adult learning also has the potential to combat ageism and social exclusion. However, for older adult learning to really contribute to such changes "it is not only the technical skills that need to be continually refreshed, not only the job-focused education that needs to be lifelong" but "the same is required, and with greater urgency, by education in citizenship" (Bauman, 2005: 126 - italics in original). Unfortunately, whilst most policies for older adult learning are characterised by a sense of urgency to keep up the rapid 'technological process', limited exigency is located "when it comes to catching up with the impetuous stream of political developments and the fast changing rules of the political game" (ibid.). This lacuna may be overturned if policy and good practices in older adult education move in parallel, whilst keeping each other informed of positive developments. Such a direction has immense potential to construct a more holistic approach to late-life learning, one that is sensitive both to the heterogeneous character of older cohorts as well as the diverse meanings that the act of learning has for different persons. Indeed, the linkage of policy and practice allows "a better understanding of the ways in which older people learn, 
whether and how they differ from those used by younger people and if so, how their learning could be enhanced" (Withnall, 2008: 3). Addressing such concerns "would enable us to move towards a more inclusive society where all forms of learning are valued, older people are held in higher esteem for the contribution they make, and learning for everyone is truly acknowledged as a desirable lifelong process" (ibid.).

\section{REFERENCES}

Alfageme, A. (2007). The clients and functions of Spanish university programmes for older people: A sociological analysis. Ageing \& Society, 27(3), 343-361.

Alzheimer Disease International. (2010). World Alzheimer report 2010. Accessed 12/5/11 from: http://www. alz.co.uk/research/files/WorldAlzheimerReport2010.pdf.

Bauman, Z. (2005b). Liquid life. Cambridge: Polity Press.

Cohen, G. D. (2006). The mature mind: The positive power of the aging brain. Basic Books, New York.

Commission of the European Communities. (2002). Council resolution of 27 June 2002 on lifelong learning. Official Journal C 163/1, 1-3.

European Commission. (2000). A memorandum on lifelong learning. Brussels: European Commission.

European Commission. (2001). Making a European area of lifelong learning a reality. Brussels: European Commission.

European Commission. (2006). Adult learning: It is never too late to learn. Brussels: European Commission.

European Commission. (2007). Action plan of adult learning: It is always a good time to learn. Brussels: European Commission.

Faure, E. (Chair) (1972). Learning to be: The world of education today and tomorrow. Paris: UNESCO.

Findsen, B. (2005). Learning later. Malabar, FL: Krieger.

Findsen, B., \& Formosa, M. (2011). Lifelong learning in later life: A handbook on older adult learning. Rotterdam: Sense.

Formosa, M. (2000). Older adult education in a Maltese University of the Third Age: a critical perspective. Education and Ageing, 15(3), 315-339.

Formosa, M. (2007). A Bourdieusian interpretation of the University of the Third Age in Malta. Journal of Maltese Education Research, 4(2), 1-16.

Formosa, M. (2012a). European Union policy on older adult learning: A critical commentary. Journal of Aging and Social Policy, 24(4), 384-399.

Formosa, M. (2012b). Education for older adults in Malta: Current trends and future visions. International Review of Education, 58(2), 271-292.

Formosa, M. (2012c). Education and older adults at the University of the Third Age. Educational Gerontology, 38(1), 1-13.

Formosa, M. (2014). Four decades of Universities of the Third Age: Past, present, and future. Ageing \& Society, 34(1), 42-66.

Hebestreit, L. (2008). The role of the University of the Third Age in meeting the needs of adult learners in Victoria, Australia. Australian Journal of Adult Learning, 48(3), 547-565.

Hodkinson, P., Ford, G., Hodkinson, H., \& Hawthorn, R. (2008). Learning as a retirement process. Educational Gerontology, 34(3), 167-184.

Lister, R. (2003) Investing in the citizen-workers of the future: Transformations in citizenship and the state under New Labour, Social Policy and Administration, 37(5), 427-443.

Livingstone, D.W., \& Raykov, M. (2013). Adult learning trends in Canada: Basic findings of the WALL 1998, 2004 and 2010 Surveys. Toronto, Canada: University of Toronto.

McNair, S. (2009). Older people's learning: An action plan. Leicester: NIACE.

McNair, S. (2012). Older people's learning in 2012: A survey. Leicester: NIACE, 
Mercken, C. (2010). Education in an ageing society. Baarn, The Netherlands: Odyssee.

Midwinter, E. (1996). U3A thriving people. The Third Age Trust: London.

Morris, D. (1984). Universities of the Third Age. Adult Education, 57(2), 135-139.

National Office of Statistics. (2009). Demographic review 2008. Malta: National Statistics Office.

National Seniors Australia. (2010). Later life learning: Unlocking the potential for productive ageing. Canberra: National Seniors Australia Productive Ageing Centre.

Parliamentary Secretariat for Rights of Persons with Disability and Active Ageing. (2013). National strategic policy for active ageing. Malta: Parliamentary Secretariat for Rights of Persons with Disability and Active Ageing.

Percy, K., \& Frank, F. (2011). Senior learners and the university: Aims, learning and 'research' in the third age. In S. Jackson (Ed.), Innovations in lifelong learning: Critical perspectives on diversity, participation, and vocational learning (pp. 126-141). New York: Routledge.

Phillipson, C., \& Ogg, J. (2010). Active ageing and universities: Engaging older learners. London: Universities UK.

Russell, H. (2008). Later life: A time to learn. Educational Gerontology, 34(3), 206-224.

Rodrigues, R., Huber, M., \& Lamura, G. (Eds.). (2012). Facts and figures on healthy and ageing a long-term care: Europe and North America. Vienna, Austria: European Centre for Social Welfare Policy and Research.

Schuller, T. (2010). Learning through life: The implications for learning in later life of the NIACE Inquiry. International Journal of Education and Ageing, 1(1), 41-51.

United Nations. (2002). Madrid International Plan of Action on Ageing. Accessed 5/2/14 from http://social.un.org/index/Portals/0/ageing/documents/Fulltext-E.pdf

Withnall, A. (2008). Lifelong learning and older persons: Choices and experiences. Teaching and Learning Research Briefing, 58, 1-4.

Withnall, A. (2010). Improving learning in later life. London: Routledge.

Workers Educational Association Northern Ireland and Age Northern Ireland. (2011) Stories of our age. Accessed 20/9/11 from: http://www.wea-ni.com/current-news-stories/stories-of-our-age.

Wrosch, C., \& Schulz, R. (2008). Health-engagement control strategies and 2-year changes in older adults' physical health. Psychological Science, 19(6), 537-541.

\author{
Marvin Formosa \\ Gerontology Unit, Faculty for Social Wellbeing \\ University of Malta \\ Malta
}





\section{BARRY GOLDING}

\section{OLDER MEN'S LEARNING AND CONVIVIALITY}

\section{INTRODUCTION}

The theoretical insights I bring to build the case come from reflections on empirical research in ten very diverse nations, presented both in Men learning through life (Golding et al., 2014), as well as from Older men learning in the community: European snapshots (Radovan \& Krasovec, 2014). This chapter argues that the radical insights initiated by older men themselves through their everyday social and community practice now call for similarly radical policy responses in more conventional adult education places and spaces.

\section{MOVING FROM CONVENTIONAL EDUCATION AND TRAINING TO THE PERIPHERY}

It is no accident that much of the early research in Australia, that informs this radical departure from conventional thinking about formal learning for work and qualifications, comes from decentred, informal learners and community organisations located towards the adult learning periphery. Field research with men learning for community purposes in similarly unlikely and unanticipated informal learning situations in remote locations played a very important role from the start of this suite of research, beginning over a decade ago with investigation of informal adult learning in small and remote towns and community settings in Victoria (Golding \& Rogers, 2003), as well as through similarly small and remote fire and emergency services organisations (Hayes et al., 2004). The common finding is that the closer one gets to community (and also as remoteness to formal learning and age increase), the more important and valuable informal, social and convivial learning becomes.

Much of this research evidence comes the Antipodes, ${ }^{1}$ from organisation types and learners at the extreme periphery, far from the increasing formality of the adult knowledge industry and markets and the world of professional educators. Informal learning by groups of older men in community settings has recently been the subject of serious study in Europe, via the European research project titled Older Men as Active Members in the Community (OMAL). The OMAL researchers set out "to investigate the problems of older vulnerable men who are marginalised, defined as less-educated men with lower socio-economic status and with low paying jobs prior to retirement" (Ricardo \& Fragoso, 2013: 81). Fragoso and Formosa's (2014) summary of the European case studies published in Radovan and 
Krasovec's (2014) book exudes the same, urgent freshness, when they talk excited about unearthing:

....an informal, situated, community-based and non-structured form of learning, millions of miles away from the rigid structures involving formal learning and vocational training that increasingly crowd in and create extra pressure on professional life. (Fragoso \& Formosa, 2014: 103)

As Radovan and Krasovek (2014: 100) noted, these "diverse and heterogeneous, informal spaces around us function as a means of opening doors to an educational vision of community". What is refreshing about these new and liberating older men's learning discourses is that they move what Fragoso and Formosa (2014: 102) describe as 'fundamental relational spaces' from the periphery to the centre of community. Hence, moving away from regarding older men as disadvantaged or 'unfortunate' - to use one of Freire's (1970) terms. Freire stressed that:

No pedagogy which is truly liberating can remain distant from the oppressed by treating them as unfortunates and by presenting for their emulation models from among the oppressors. The oppressed must be their own example in the struggle for their redemption. (Freire, 1970: 54)

It is important to acknowledge this liberation by older men, providing evidence of an ability not only to self-organise, speak up and refuse to be institutionalized other than a last resort - as Fragoso and Formosa (2014: 102) put it - but also to answer back with considerable clarity and agency. What older men are in effect saying is that intergenerational conviviality, "contact with people of all ages is at the centre of [their] social experience" (ibid.: 103), and that community, not paid work or education and training "is the intrinsic and natural solution" (ibid.: 102).

I recognise that Gorard's (2010) work debunking 'barriers' had a particularly powerful influence on my more recent thinking. As Gorard (ibid.: 355) notes, the research evidence about barriers to learning "is almost entirely based on the selfreports of existing participants" in formal education. Non-participants, in this case older men on the periphery, "usually cite other reasons for not continuing with formal education" (ibid.). What my work with others on the periphery suggests is that it is education and training contexts appropriate to the needs and interests of older men that are missing, not necessarily the learners. As Gorard (2010: 357) eloquently put it, "[m]ost non-participants are not put off by barriers, but by their lack of interest in something that seems alien and imposed by others".

\section{DRAWING CONCLUSIONS ABOUT OLDER MEN LEARNING}

Knowledge from research, encouraged by espoused concerns about older men's learning and its relationship to men' ageing and wellbeing in later life, has broadened in the past decade. This knowledge is summarised in two overarching conclusions in Men learning through life (Golding et al., 2014). Our first conclusion was that: 
[T]he opportunities for men to participate in informal and non-formal learning (in particular for unemployed men and men drawn from disadvantaged backgrounds) is quite limited and in decline. This is in part due to the general narrowing of national education and training policies to focus exclusively on promoting education and training for entry and re-entry to paid work. (Golding et al., 2014: 255-256)

Our second conclusion was that:

Those men of all ages who stand to benefit from most lifelong and lifewide learning are those least likely to access it, particularly if it is packaged and presented in a way that is patronising from deficit models of provision...[A]lmost counter-intuitively, the most effective learning for most men with limited prior learning is informal, local and community-based, which builds on what men know, can do and are interested in. Learning for such men is less effective if it assumes all men have a problem, that particular masculinities are the problem or if it requires them to be served up curriculum and assessment for qualifications, vocational training or literacy, as students, customers, clients or patients, which presuppose a deficit. (Golding et al., 2014: 256)

\section{OLDER MEN AS LEARNERS: SOME INTERNATIONAL COMPARISONS}

It is striking that the set case studies by researchers in Estonia, Malta, Portugal and Slovenia (Radovan \& Krasovec, 2014) throw up many of the same emergent theoretical issues as those from Australia. What is different is that many of the same issues in Europe extend also to the greater proportion of younger men unemployed as a consequence of the Global Financial Crisis. Radovan and Krasovek's (2014: 24) book provides new evidence from very diverse European community contexts that "the crucial means of developing older men's interest in informal learning is not learning per se, but the possibility of communicative cooperation in diverse, informal places and spaces underpinned by approaches that value older men's agency, rather than simply 'doing courses"'.

The European book's overarching conclusion by Fragoso and Formosa refers to both Freire's (1970, 1985) Pedagogy of the oppressed and The politics of education, which situate the learner as the subject rather than the object (and certainly not the customer or the client). Fragoso and Formosa (2014: 101) also stress the importance of social learning for older men, contradicting "the pessimistic categorisation of older people that reifies older citizens as dispensable, non-economic items"', or worse, as an economic liability. 


\section{PROLIFERATION OF MEN'S SHEDS}

The other major and quite radical development, with the potential to spread to other parts of Europe, is the community men's sheds movement. Sheds have not only spread numerically but also broadened in purpose and scope. Men's sheds are now open in most towns across Australia and Ireland, with shed densities now remarkably similar in both countries, but with much higher densities in rural areas with a higher proportion of older men. The lessons here from this growing, grassroots, men's shed sector, should now be very clear. Given that the first men's shed opened in Australia only 15 years ago (and in Ireland barely five years ago) and that the median age of Australian shedders is 68 years, the men's shed movement raises many questions about the wide range of unmet needs of mainly older men not in paid work, that men's sheds clearly tend to attract.

If someone had predicted the rapidity and nature of this spread from a handful of precursor sheds in rural South Australia from the mid-1990s, I would not have believed them. This remarkable story and the way the movement has spread elsewhere during the past two decades is being researched and documented during 2014 for my forthcoming book, The men's shed movement. There are more than 1,000 men's sheds open in Australia, two hundred in Ireland and 70 each in New Zealand and the United Kingdom, with many active national and state associations (Australian Men's Shed Association, 2014). While theory and research are scrambling to catch up (Golding, 2014b), the men's shed movement rolls on. What research for my forthcoming book shows is that it is deliberately decentred and grassroots, that men's sheds are differentially located in smaller rural communities, mainly led by older men as participants, but providing significant opportunities for intergenerational learning and mentoring for younger men.

\section{MEN'S SHEDS REVEALED}

I am assuming at this point that few readers in Europe either understand what a men's shed is from reading about it (Golding, 2014a), or have actually visited one. I will introduce sheds in three ways. Firstly, through the words of a 'shedder' asked about his shed's engagement with the community; secondly, through a summation by a British academic who recently visited and reflected on men's sheds in Australia in a blog, and thirdly, through a grounded, personal account of a shed in Belfast, Northern Ireland.

\section{Evidence of one shed's engagement with and contribution to its community}

This section seeks to illustrate the impact of learning through one Australian men's shed that goes well beyond the conventional notion of the individual learner doing a course of study. This shed is in a very small, rural Australian town (population 1,300 people), and only opened in mid-2011. The shedder was asked in an online survey two years later, "In what ways does your shed engage with and contribute to its community?" While identifying information has been removed and acronyms 
have been expanded so it can be understood internationally, the reply is essentially quoted verbatim below, as it was typed into the text box:

Our Activities. Since we commenced in July 2011, we have conducted one funeral and two wakes in the shed. Our proximity to the [local] Aged Care facilities provides us with several members who regularly visit from the facility and enjoy the opportunity to get out from the four walls. We regularly cater for gatherings and have recently increased our catering facilities [through community donations]. The new items were provided through a grant from the Federal Government through the Australian Men's Shed Association. Supporting disengaged youth and secondary students with mentoring in a billycart building program and ... our Bicycle Recycling Program. This program also engages men over 55 with volunteer work through [the Office of Employment]. We have started and supported the following activities through the shed: Supporting aged residents of [District] Rural Health by constructing pathways from the residences to the Shed and the [Local] Bowling Club to enable ease of access to these venues for persons of limited mobility along smooth pathways. ... Building bench chairs and garden furniture for rest spots along the pathways and other areas of [the local Hospital] grounds, such as the Indigenous garden. Manufacturing occupational therapy items for use by stroke victims. Participating in community activities such as raffles and barbecues to raise funds for needy projects in the community. Originally started [in this town] as a six-monthly Get-Together of Men's Sheds in the [Local] Shire to exchange ideas and work together to grow the concept of Men's Sheds, the Get Together is now quarterly and includes [two] sheds [at some distance]. We host a regular community kitchen where healthy cooking and recipes are trialled and conceived. A monthly food swap was hosted at the shed. We were asked to make 20 ornamental wheelbarrows for a family day at one of the food swap meetings. [The local Health Service] provided us with a grant to set up a community garden in the Shed precinct. We have set up raised garden beds to suit the limited mobility of our age group beside the pathways around the shed area and provided six beds for the residents in the hostel area. A garden shed has been provided to house tools and supplies and there are several beds already rented out to community members. Indigenous craftsmen are utilizing our equipment to manufacture boomerangs and other artefacts. Several [Department of Veterans Affairs] persons are actively involved in the shed. Commencing [a] walking group from the shed as a non-competitive... activity for those with low mobility skills. We raised A $\$ 600$ for the [Local] Kindergarten and [also for] the District Nursing Service. The [Country Women's Association] and other contributors joined us in presenting two [Global Positioning] units to the [Local] Ambulance [to help cut] attendance time. We are currently working on a secret project for the "Make a Wish Foundation" [for children with Cancer]. An old horse drawn dray has been 
restored....and is on display in the Pioneer Museum together with a restored

Railways hand trolley made with 80 year old recycled timber.

What is striking is that while all of this response is about the shed's contribution to the community, as requested, the learning and conviviality intrinsic to each activity and its outcomes are diverse and extensive.

\section{An academic's blog response to the conviviality of men's sheds}

This section seeks to illustrate conviviality through learning via recent blog by an English lecturer, Dr Brendan Hoare. It is adapted below with Brendan's permission to give an insightful theoretical response to sheds from an academic 'outsider'. Having heard about men's sheds while visiting Australia, he neatly and very perceptively summed it up as follows:

A men's shed is a meeting place for men; it is a place where men of all ages can go to talk, interact, learn and further their general wellbeing in any number of ways. Those men who are no longer in paid employment due to age, redundancy or economic conditions can find a place and a purpose beyond the workplace, the home or the pub; a convivial place (and we shall come back to that word later) where learning may take place, but where there are no rules or expectations except their own. There are no managers, no professionals, no experts, no teachers except themselves, and they have to meet nobody's objectives or fit in with anybody's plans except their own. Furthermore, these sheds are mushrooming across the world, an amazing organic growth, driven by the perceived need of those involved, rather than by policy, whether institutional or governmental. Akin to guerrilla gardening in its 'bottom up' spontaneity and virtual absence of institutional control, it could almost be seen as a form of guerrilla education; perhaps, a revolutionary new approach to learning. (Hoare, 2014)

The author went on to draw:

...striking parallels in this new model with the remedies for the ills of our current education system proposed by Ivan Illich's Deschooling Society (Illich, 1971), a work, which although much neglected in recent decades, appears no less radical today than it was over forty years ago. What Illich proposed was a total deinstitutionalisation of an education system that was designed to reproduce the status quo and shore up an inherently inequitable society. As Illich put it, 'School is the advertising agency which makes you believe that you need the society as it is' (Illich, 1971: 113). Illich's solution was to allow people to decide upon their own goals and their own curriculum within a setting of mutual help and concern, and with access to the resources they would need. As Illich argued, most learning is not the result of instruction. It is rather the result of unhampered participation in a meaningful 
setting. Most people learn best by being with it, yet school makes them identify their personal, cognitive growth with elaborate planning and manipulation. (Illich, 1971: 38)

This response, including an extension of Illich's remedies to the ills of our current adult education system, are returned to later in the Discussion section.

\section{Personalising men's sheds as a form of intergenerational practice}

My third way of introducing men's sheds is to come out from behind the academic anonymity, characterised by its theory and generalities, to introduce a picture I took, as an older man myself (age 64). It was taken in February 2014, of Geordie Murtagh with his son Oisin, active participants in the Crann go Beatha ('Tree of Life') Men's Shed in the Falls Road area of Belfast, Northern Ireland. Falls Road is a site synonymous with the Republican community during the conflict that wracked this part of the world until the Good Friday Peace Agreement in 1998. In that same year, the first ever, named community 'Men's Shed' opened on my, 'other side' of the world in Lane Cove in Sydney. This Shed, lovingly created in a former flax mill in Belfast, has 120 men of all ages through the door each week, cutting across generations and the ethno-nationalist divide, transforming men's and boys' lives.

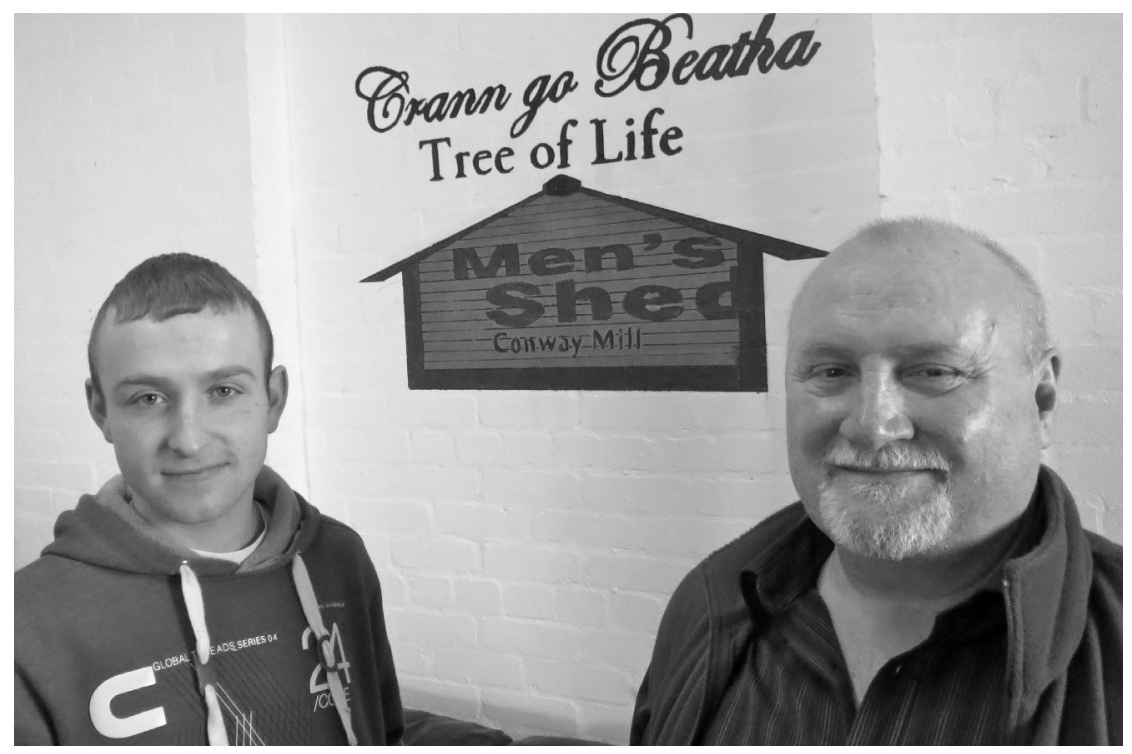


Bradshaw (1997) espoused similar purposes for adult and community education in her conceptual framework for Australian ACE. Chaos theory suggests that something as small as a butterfly's wing can ultimately cause a cyclone halfway round the globe. I have included this photograph, with Geordie and Oisin's permission, as an example of this effect through the men's shed movement. The same cyclone blows winds of transformative change each day through the lives, families and communities of tens of thousands of older men in over one thousand different and diverse Australian men's sheds on the other side of the globe, nine out of ten of which have no paid staff.

\section{DISCUSSION: \\ CONVIVIALITY, SHEDS AND SOCIAL TRANSFORMATION}

It is useful at this point to return to and draw some parallels between some of Illich (1971) and Freire's (1970) thinking about learning, conviviality and socialisation. Not surprisingly, Freire confirmed in an interview published in 1982 that they were 'great friends' (Freire \& Kirby, 1982: 45). These 'old arguments' are returned to because of the way they inform contemporary arguments about a radical restructuring of adult education for some older men.

Essential to Illich's (1973) proposal for Deschooling society and his suggested replacement of institutional control over learning, was the development of "learning webs" and "tools for conviviality". Of course, the learning webs envisioned in 1973 were not the present world wide web, although Illich did foresee the impact technology might have in freeing education from those who would wish to control it. He was as much concerned then with access to human webs for educational support, as with technological assistance:

A good educational system should have three purposes: it should provide all who want to learn with access to available resources at any time in their lives; empower all who want to share what they know to find those who want to learn it from them; and, finally, furnish all who want to present an issue to the public with the opportunity to make their challenge known. (Illich, 1971: 75)

Illich expanded upon this suggestion in Tools for conviviality, in which conviviality was defined as a dynamic replacement for the control of human activity by institutions, professionals and managers.

I intend it to mean autonomous and creative intercourse among persons, and the intercourse of persons with their environment; and this in contrast with the conditioned response of persons to the demands made upon them by others, and by a man-made environment. I consider conviviality to be individual freedom realized in personal interdependence and, as such, an intrinsic ethical value. (Illich, 1973: 11) 
Illich (1971: 105) laid down four goals for his 'educational revolution', which are pertinent and timely when discussing men's sheds and 'shedagogies', a term I playfully (but also purposefully) floated in a recent conference paper (Golding, 2014c). Illich's (1971: passim) goals were all about liberation: the first was about 'abolishing the control which persons and institutions now exercise over their educational values'; the second was to enable 'the sharing of skills by guaranteeing freedom to teach or exercise them on request'; the third was effectively about giving agency to individuals to break the monopolisation 'by institutions which claim to speak for the people'; and the fourth was about liberating 'the individual from the obligation to shape his $[\mathrm{sic}]$ expectations to the services offered by an established profession'. Illich concluded, continuing in the sexist language of the day, and amended to be inclusive of education systems beyond schools, by stressing that the "creature whom [formal education systems] need as a client has neither the autonomy nor the motivation to grow on his own" (ibid.: 105).

Freire came at some of the same arguments by postulating his "pedagogy of the oppressed', elegantly and recently summarised by Schugurensky (2011) in contemporary terms. Freire emphasised:

...the distinction between systematic education, which can only be changed by political power, and educational projects, which could be carried out with the oppressed in the process of organising them. (Freire, 1970: 30-31)

Freire encouraged teachers "to engage in forms of critical practice that interrogate, destabilise, and disorganise dominant power/knowledge relations, and at the same time, develop alternative pedagogies" (Schugurensky, 2011: 198). It is in this context that I invoke shedagogy as an educational project, amongst other similar radical transformative projects through the men's shed movement (Golding, 2014c). While this rereading of Freire's radical proposal from 45 years ago certainly identifies some strong contemporary resonances, I am at pains to point out that the theorising I am engaging in by invoking Freire and Illich when discussing men's sheds is an old explanation which I am applying to a new and very different context. To use some of Freire's ideas, mediated by Schugurensky's (2011) words, men's sheds are in part about older men working together to build 'a more human and democratic society without exploitation and exclusions' (p. 104); affirming older men as learners and 'active beings in the process of becoming' ( $\mathrm{p}$. 104); bringing together the act of knowing existing knowledge and the act of creating new knowledge' (p. 104); creating spaces 'of dialogue and participation' and 'the construction of popular power through democratic organisations and coalitions'.

Lest this sounds overly cosy and utopian, it is important to note that some men's sheds are so liberatory, grassroots and independent that they also refuse to subscribe to any shed-based national organisation. As one New Zealand men's shedder said recently in the fiercely independent South Dunedin Blokes Shed, 
We don't consider that we need international recognition ... These guys have all been on more committees than you can shake a stick at and they don't want to know about them. They'd sooner get on without too much pussyfooting around. (Otago Daily Times, 13 May 2012)

\section{Would Illich and Freire Have Liked Men's Sheds?}

Quite apart from their role in aligning with many of the social determinants of health (Macdonald, 2014), men's sheds might be seen in this sense as one of many convivial, post-institutional alternatives to formal learning, and perhaps to a welcome signpost towards a more inclusive and progressive education is beginning to emerge for some older men. It is fascinating (but not surprising) that Freire's persuasive theorising about learning and power, and Illich's radical, but still valid arguments for deinstitutionalising schooling from over three decades ago, are virtually unknown to many young adult education academics and practitioners. With most formal education systems for adults now resembling work-dominated 'markets', with dollar discourses replacing pedagogical ones, and with two of Illich's three criteria for 'good education systems' (above) now technically feasible via the internet, Illich and Freire are certainly worth revisiting in 2014. I suspect both men would have enjoyed men's sheds and delighted in shedagogy.

\section{CONCLUSION: \\ LIFELONG AND LIFEWIDE LEARNING BY OLDER MEN}

In conclusion, and coming back to the difficult reality faced daily by adult education providers and practitioners in many countries as they face new ways of making learning relevant for older men, it is important to continue to look for:

... policies that include agency around discourses of equity, inclusion, health and wellbeing, and not just a de facto education system that is valued only for vocational outcomes and competencies. (Golding \& Foley, 2011: 67)

Most modern adult educators inhabit increasingly formal education sectors in an increasingly barren landscape dominated the dead hand of curriculum, assessment, quality and compliance. This nightmare 'quadrella' is something of a desperate race to the vocational bottom, justified by the "new economistic rhetoric of individual rights and ideologies of 'efficiency' and 'choice"' (Welch, 2010: 244). Men's sheds are proof that there are many other learning landscapes, where community agency is possible, where older men are empowered, and the broader wellbeing of the community are still valued.

I have tried in this chapter to emphasise that it is critically important to think, act and theorise beyond 'provision' and 'providers' that presuppose that learning is only a product, 'delivered' to customers, clients and students. The key to understanding and transforming adult and community learning and literacies for older men requires us to avert our gaze beyond the market and the classroom, to 
look and act elsewhere to enhance and facilitate less formal learning, and to empower learners in the many other valuable and fascinating spaces, pedagogies and practices that remain embedded in very diverse community interstices,

... symbolic spaces that frame people's sense of belonging, ... built from symbols that have powerful meanings in the community. (Fragoso \& Formosa, 2014: 100)

\section{ACKNOWLEDGEMENT}

I acknowledge Dr. Brendan Hoare from the University of Chester in the United Kingdom, who first alerted me to the link between some radical aspects of men's sheds in community settings and Illich's thinking about deinstitutionalised learning.

\section{NOTES}

1 In geography, the antipodes of any place on Earth is the point on the Earth's surface, which is diametrically opposite to it. In the Northern Hemisphere, 'the Antipodes' is often used to refer to Australia and New Zealand, and 'Antipodeans' to their inhabitants.

2 A 'quadrella' in Australia and New Zealand refers to a bet or wager, usually in horse racing, where the bettor must pick the winners of four nominated races at the same track.

\section{REFERENCES}

Australian Men's Shed Association. (2014). Australian Men's Shed Association. Accessed 28 May 2014 from: www.mensshed.org

Bradshaw, D. (1997). Transforming lives, transforming communities: Conceptual framework for further education curriculum. Melbourne: ACFE Board.

Fragoso, A., \& Formosa, M. (2014). Discussion and conclusion. In M. Radovan \& S. J. Krasovec. Older men learning in the community: European snapshots. Ljubljana, Slovenia: University Press.

Freire, P. (1970). Pedagogy of the oppressed. New York: Continuum.

Freire, P. (1985). The politics of education: Culture, power and liberation. South Hadley, MA: Bergin and Garvey.

Freire, P., \& Kirby, P. (1982). Interview with Paulo Freire. The Crane Bag, 6(2), 45-48.

Golding, B. (2014a). Men's sheds: A new movement for change. In B. Golding, R. Mark, \& A. Foley (Eds.), Men learning through life (pp. 113-128). Leicester: NIACE.

Golding, B. (2014b). Research bibliography. Accessed 2/9/14 from: http://barrygoanna.com/research/

Golding, B. (2014c). Men learning through life: Floating the theory of shedagogy. Paper to ESREA Older Learners Network Conference, Valletta, Malta, 23 October 2014.

Golding, B., \& Foley, A. (2011). All over red rover? The neglect and potential of Australian adult education in the community. Australian Journal of Adult Learning, 51(Special Edition), 53-71.

Golding, B., \& Rogers, M. (2003). Adult and community learning in small and remote towns in Victoria, Paper to Australian Vocational Educational and Training Research Association Conference, Melbourne, 21-22 March 2003.

Golding, B., Mark, R., \& Foley, A. (2014). Men's turn to learn: Discussion and conclusion. In B. Golding, R. Mark, \& A. Foley (Eds.), Men learning through life (pp. 244-59). Leicester: NIACE. 


\section{GOLDING}

Gorard, S. (2010). Participation in learning: Barriers to learning. In C. Cooper, J. Field, U. Goswami, R. Jenkins, \& B. Sahakian (Eds.), Mental capital and wellbeing (pp. 351-360). Chichester, West Sussex: Wiley-Blackwell.

Hayes, C., Golding, B., \& Harvey, J. (2004). Adult learning through fire and emergency service organisations in small and remote Australian towns. Adelaide: NCVER.

Hoare, B. (2014). The conviviality of the shed. Terra Incognita, Accessed 2/9/14 from http://terraaustralisincognit.blogspot.com.au/2014/05/the-conviviality-of-shed.html

Illich, I. (1971). Deschooling society. Harmondsworth: Penguin Books.

Illich, I. (1973). Tools for conviviality. London: Fontana.

Macdonald, J. (2014). Men's health and wellbeing: Learning through the lifecourse. In B. Golding, R. Mark, \& A. Foley (Eds.), Men learning through life (pp. 34-48). Leicester: NIACE.

Radovan, M., \& Krasovec, S. J. (2014). Older men learning in the community: European snapshots. Ljubljana: University Press.

Ricardo, R., \& Fragoso, A. (2013). Older men learning in the community: The case of the amateur fishing club of Faro. In Irena Žemaitaityt \& Sarmit Mikulionien (Eds.), Proceedings of ESREA $4^{\text {th }}$ International Conference: Learning opportunities for older adults: Forms, providers and policies (pp. 77-88). ESREA.

Schugurensky, D. (2011). Paulo Freire. London: Continuum.

Welch, A. (2010). Making education policy. In R. Connell, C. Campbell, M. Vickers, A. Welch, D. Foley, N. Bagnall, \& D. Hayes (Eds.), Education, change and society (2nd ed., pp. 235-271). South Melbourne: Oxford University Press.

\section{Barry Golding}

Faculty of Education \& Arts

Federation University Australia

Australia 


\title{
4. EDUCATION AND EMPOWERMENT IN LATER LIFE
}

\begin{abstract}
INTRODUCTION
In recent times, adult education has witnessed an increasing number of activities aimed at older adults (Findsen \& Formosa, 2011). From social and cultural programmes, to literacy and local development projects, older adult education has become a major issue in policy making. One locates guidelines emanating from international bodies ranging from the European Union (European Commission, 2006, 2007) to the United Nations (2002), that advocate public and nongovernmental organisations to implement social policies and leisure projects that relate to learning and which target older adults. Such policy trends have been discussed by a number of authors, such as Findsen (2005), using various theoretical and analytical approaches. One key standpoint is the functionalist perspective which celebrates the concepts inherent in activity theory above other visions, and which supports the adoption of functionalist rationales directed at older adults (McClusky, 1974). Policies following such a vein of though argue that adults have to avoid decline in later life. Even if older adults adopt activities that are similar to those followed in midlife, such actions are nonetheless regarded as beneficial for retired people. A key counterpart to such a position is the critical perspective which perceives the empowerment of individuals and emancipation of social groups as extremely relevant to the theory and practice of older adult education (Formosa, 2000). This critical perspective, based on the tenets of radical theory, aims to change the ways that older adults' life conditions are fostered, and favours a real transformation of peoples' lives by democratizing access to, and participation in, education (Glendenning \& Battersby, 1990; Glendenning, 2000). In other words, it supports a kind of education for older adults which promotes individual emancipation and social empowerment as part of the learning process. It is in the context of critical educational gerontology that older adult education results in furthering the available opportunities for social participation and active citizenship.
\end{abstract}

\section{ADULT EDUCATION}

Several authors have theorised and researched adult education. Contingent on the assumption of high diversity in adult education and within the framework of education practice, Canário (1999) discussed possible activities and, in particular, 
its goals, objectives and target audiences, as well as the qualities and skills that educators or trainers involved in older adult education should possess. Canário singled out several foci for intervention - including formal primary education, continuous vocational training, local development and socio-cultural programmes and also highlighted the relationship between adult education and the life course experience. Similarly, Foley (2004) focused particularly on the various dimensions of adult learning, and drew a distinction between formal education, non-formal education, informal learning, and incidental learning, albeit also highlighting the limits of such fields of practice. Furthermore, apart from the traditional areas of education intervention - that is, basic education, university education, vocational training and community education - Foley (ibid.) highlighted other emerging fields of intervention that have generated 'distinctive forms of education'. Such forms include those targeted at specific adult groups such as older persons, and which are supported by organizations promoting late-life learning, most especially, the University of the Third Age.

Adult education has been analysed through several theoretical frameworks. Finger and Asún (2001), for example, identified pragmatism, humanism and Marxist adult education and other analytical perspective on the basis of the importance given to individual empowerment and the social emancipation of groups in the context of critical pedagogy. All these viewpoints are key concepts in the field of adult education, revealing different traditions since the Enlightenment that are each intertwined to the notions of freedom and autonomy. Freire (2005) also discussed the concepts of empowerment and social emancipation as part of the analysis of oppressive structures, practices and theories. He argues that adult education activities should be based on problematization and directed towards raising the subjects' awareness of oppressive power relations between different social agents. Hence, the attention in Freire's (ibid.) work was focused on the importance of accepting emancipation as a point of departure, rather than an outcome of education, one that involves the continuous reflection and dialogue between both learners and teachers.

The education of older adults emerged rather recently as a field of inquiry within adult education. The topics that can be singled out from the literature are varied and include the wisdom of older adults (Jarvis, 2012), community and intergenerational learning (Boström, 2012), the role of state and non-governmental organizations (e.g. Elderhostels and Universities of the Third Age) in promoting education for senior citizens (Veloso, 2007; Formosa, 2014), the significance of learning for older individuals (Hake, 2012), and the various teaching-learning models for older persons such as geragogy and gerontagogy (Berdes et al., 1992; Lemieux \& Martinez, 2000; Formosa, 2002, 2012). The goals of the education of older adults remain entrenched in a quest to arrive at rather more consistent definitions of important concepts for this field of study, and to identify thematic and relevant methodological issues. Although this area has gained from relevant and recent contributions, it is also true that the field is still struggling to establish itself as a discipline, mostly because the definitions of older adults, later life and 
ageing adopted by researchers are highly diverse, as indeed, are the posited methodological approaches (Veloso et al., 2011; Krasovec \& Radovan, 2012).

\section{FROM EDUCATIONAL GERONTOLOGY $\ldots$}

Throughout history older persons were generally left out in the cold as far as educational opportunities are concerned (Boulton-Lewis \& Tam, 2011; Findsen \& Formosa, 2011). However, the goal posts changed dramatically with the coming of the third age (Weiss \& Bass, 2002). As an increasing number of older persons experience a smooth material and financial transition from working life to retirement, attention is directed towards their post-materialist resources especially, identity capital, human capital, and social capital (McNair, 2009). First, the coupling of a second modernity with a third age lifestyle makes older people experience 'ontological insecurity' which tears down their established 'midlife' identity usually based upon occupational and familial experiences. In such events, older persons are quick to take advantage of learning opportunities to develop and maintain a 'new' sense of identity, self confidence, control over their lives, and civic engagement with other people. Second, education becomes instrumental in developing the skills and knowledge needed to find and retain sustainable and satisfying employment, both paid and unpaid. This has become increasingly complex due to the rapidly changing labour market and the expansion of the numbers of people in the third age, so that the rising number of third agers engaging in re-skilling vocational courses comes as no surprise. Finally, as people become older they experience a decline in their levels of social capital since children are becoming more geographically mobile and as members of their social network relocate to retirement communities, enter residential/nursing homes, or pass away. Education and learning activities are thus increasingly viewed as efficient strategies to make new friends, acquaintances and possible partners, as well as reinforcing existing relationships.

The above factors were all of key importance in turning the attention of academics in both adult education and gerontology towards the field of 'educational gerontology'. According to Glendenning (1985), the term educational gerontology was first used at the University of Michigan as the title of a Doctoral programme promoted by a Professor of Education, Howard Y. McClusky. This programme "was crucial in embedding older adult learning in an academic context" (Findsen \& Formosa, 2011: 52), and focused mainly on that interface between education and older adults (Withnall, 2002). Educational gerontology was eventually defined by Peterson (1990) as a field of study and practice for older adults and ageing, with the relation between these two areas characterizing older adult education, whilst at the same time constituting a sub-field of these two fields. Peterson (ibid.) included three main areas within educational gerontology: education for senior citizens, training of professionals to work with this group and training for other groups about senior citizens and ageing. Over the years, this definition of educational gerontology has been reshaped, especially by Glendenning (1990, 2000), who put forward two key aspects of educational 
gerontology - namely, older adult education on one hand and gerontological education that focuses on the teaching of gerontology to professionals working in the field of ageing on the other.

However, the concept of educational gerontology remains unambiguous since there have been other definitions and divisions. In this respect, the research and reflection by Findsen and Formosa (2011) on the use of the terms 'educational gerontology' is noteworthy. According to these authors, both terms "have lost their momentum as definitional terms" (ibid.: 54). Indeed, Findsen and Formosa examined various issues of the journal Educational Gerontology and found that in many articles the term 'educational gerontology' was used to refer to the teaching of studies on ageing linked to undergraduate and graduate courses, targeting especially allied health professionals and para-professionals. This situation was found to be just as common in other books and articles, with Findsen and Formosa concluding that although educational gerontology was not used to denote the education of older adults as such, different authors resorted to a variety of terms to discuss this field. Another important finding was that most of the authors writing in Educational Gerontology were not gerontologists: "that the past two decades witnessed 'educational gerontology' moving away from academic gerontology and positioning itself more within the fields of adult and lifelong learning" (ibid.: 55).

\section{... TO CRITICAL EDUCATIONAL GERONTOLOGY}

One theory that had a major influence on the field of educational gerontology was Havighurst's (1954) functionalist theory of activity, which addressed the problem of role changes with the alteration of activity in later life (Veloso, 2011). Following retirement, different situations may occur in older adults' social roles, with some roles becoming more intense and others less so. New roles may even emerge in areas such as recreation, family affairs and religious activities. Following this line of thought, the development of different educational and learning activities and, simultaneously, the roles performed by older adults, lead to a greater feeling of happiness and adaptation to the challenges brought on by later life.

The above standpoint has attracted considerable criticism, particularly from authors in the field of educational gerontology. Glendenning and Battersby (1990) argued that the education of older adults was based on erroneous assumptions promoted by the functionalist paradigm, and that the paradigm had to be changed. They note that this theory is wrongly based on the assumption that older adults constitute a homogenous group. In the educational field, this is expressed in educational programmes that particularly target older adults from the middle classes, with their interests being reflected in the curriculum. Glendenning and Battersby (ibid.) also emphasized the need to question what has been done for the education of older adults, not only to allow wider participation access, but also to prevent their marginalization in society. All the criticism that these authors levelled at activity theory demonstrated a strong shift from the functionalist to the sociopolitical paradigm. This shift helps practitioners and theorists in older adult education to understand how many older adults are marginalized in society, and to 
question educational practices by arguing in favour of a 'liberating education' that promotes social empowerment, emancipation and transformation - a position which is based on the educational philosophy of Freire (2005). In critical educational gerontology, social change is expressed through the awareness of social inequalities that learner's experience and which lead to their marginalization. A conception of dialogic education is thus required to drive social change, as it has the potential to enable a relationship between knowledgeable subjects and the world. Hence, overcoming the hegemonical relationship that results from 'banking education', a 'top-bottom' teaching process where learners are simply considered as the depositaries of knowledge dispensed by expert teachers.

The foundations of a liberating education presuppose a dialogical education which implies changing the way teaching is done. As Freire (2005: 47) underlines, "knowing how to teach is not transferring knowledge but creating the possibility for its actual production or construction". The teacher has to have listening skills to create the conditions for knowledge creation. This means that, whoever "talks and never listens; whoever 'carries' knowledge and gives it to students ... has nothing to do with liberation or democracy ... whoever acts and thinks this way, deliberately or not, helps to preserve authoritarian structures" (Freire, 2000: 26). Formosa $(2005,2007,2010 a)$ is a key supporter of this standpoint and wrote extensively on critical educational gerontology. Very pertinently, he draws attention to the need for and relevance of transformative education for senior citizens that offers empowerment and emancipation. In Formosa's words (2010b: 9), "rather than simply enabling people to adapt to and reintegrate within the existing system, transformative education seeks to empower groups to confront the inequitable and oppressive system with a view to changing it". Inspired by Freire's (1972) philosophy of education, the authors put forward four major principles for a critical epistemology in late-life education (Glendenning \& Battersby, 1990: passim):

- an exploration of how the relationship between capitalism and ageing influences the concept and practice of education in later life

- a critique of the dominant liberal tradition that involves a negation that education for older persons is essentially a neutral uncontested enterprise

- the inclusion of concepts such as emancipation, empowerment, transformation, social and hegemonical control and what Freire calls 'conscientisation'

- developing 'the notion of praxis' to establish a 'critical gerogogy' which leads older people to greater control over their own knowledge and thoughts.

More recently, Formosa (2011: passim) proposed a contemporary set of principles for critical educational gerontology:

A transformative rationale. Critical educational gerontology is afraid with 'how' and 'what we are producing, who it benefits, and who it hurts'. It not only aims to dissect the realities surrounding us but also to enable learners to imagine and work together towards the realisation of a social world than is governed by life-centred values rather than the ideology of the market. A critical pedagogy 'reject[s] a 
fatalistic or pessimistic understanding of history with a belief that what happens is what should happen' (Freire, 2002: x).

Educators yes, facilitators no! Contrary to a common misconception that critical pedagogy is 'non-directive' and a 'dialogue of equals', in CEG the educator and learner are not on an equal footing. Whilst Freire (1985: 177) recognises that teachers 'have to learn from our students', he also underlines that 'at the moment the teacher begins the dialogue, he or she knows a great deal, first in terms of knowledge and second in terms of the horizon that he or she want to get to' (in Shor \& Freire 1987, 103).

Critical geragogy. Geragogical prerequisites for critical educational gerontology also include listening, love and tolerance. Whilst it is only as a result of listening that one can overcome 'narration sickness' which makes us talk past each other rather than to each other, a geragogy of love embraces and cherishes the hope that we could exist as full human beings, having the freedom to live passionately with an 'increasing solidarity between the mind and the hands' (Freire, 1997: 33).

Revolutionary praxis. Critical educational gerontology entails a critical engagement with historically accumulated concepts and practices - that is, a 'reflection and action upon the world in order to transform it' (Freire, 1972: 52). Humanisation is only achieved through intentional, reflective, meaningful activity situated within dynamic historical and cultural contexts that at the same time shape and set limits on that activity. In critical educational gerontology both teachers and learners need to extend their work outside the educational setting, and connect with what is going on in the public sphere.

As to be expected, critical educational gerontology has also been open to numerous reservations. One early critical exposition of critical educational gerontology is found in Percy's (1990) work which argued that older persons are in reality a highly heterogeneous group so that it is fallacious to generalize this social grouping as 'disadvantaged' or 'disempowered' situations. Assessing the objectives of critical educational gerontology as stated by Glendenning and Battersby (1990) which above else noted increasing the awareness of older adults about their rights and the need for improved levels of active citizenship, and older adults should have control over their thinking and even gain power over their lives - Percy (1990) noted that despite many older people lack all or some of money, health, security, and social contact - later life is still marked by extensive heterogeneity so that many elders are actually positioned in advantageous positions. The objectives of critical educational gerontology are therefore perceived by Percy as too 'dubious', 'comprehensive', and 'wide-ranging', to be successfully tackled by educational classes attended by a very minute percentage of older adults. Inspired by the humanist emphasis on the 'freedom to learn' and 'self-actualisation', he argued that learning:

... is essentially a matter of personal quest. Learners begin from where they are; they follow the thrust of their own curiosities in order to make what is 
around them more meaningful; ideally they should be free of external constraints so that they can learn until they are satisfied, until they have achieved the potential that is within them. (Percy, 1990: 236)

Percy advocates a humanist standpoint for educational gerontology where both the education goals and the learning of the older adults are similar to those of a person of any age in the sense that education should provide each individual, regardless of age, an opportunity for self-development. To cite Percy (ibid.: 236): "to be fully human, to exploit the potential to being alive, this perspective implies, one has to be continuously a learner and the proper society would make this possible". Regarding the interests served by education, Percy argued that it is the interests of everyone, and older people in particular, that should be promoted. This is achieved by upholding the goal that he sees to be at the centre of older adult education namely, self-fulfilment - since "our society would be a better society if the educational potential of older people were to be fully used" (ibid.: 239). In counteraction, critics of the humanist standpoint stress upon the difficulty to consider human beings as free, as having an inner goodness, seeking selfdevelopment and, in favourable circumstances, managing to achieve their potential (Finger \& Asún, 2001). In light of this, Formosa (2011: 322) explained how the premises of humanist adult education are ill-founded: "unfortunately, such premises are situated in a social vacuum, entrenched in therapeutic and individualist approaches to personal development, and assume that a disparate group of self-actualised individuals lead automatically to an improved society". Furthermore, he pointed out that the humanistic perspective does not give due weight to the influence of socio-historical, political and economic conditions on human life. This implies that, contrary to Percy's (1990) claims, older adults are not entirely free to follow their own interests, but "are constrained by the persistence of lifelong positions in repressive locations in terms of class, gender, race, ethnicity, sexuality, and, especially in our case, acts" (ibid.: 322).

More recent criticisms towards critical educational gerontology is found in Withnall's (2000, 2002) writings where albeit agreeing that educational gerontology needs a new paradigm to enable it to answer important questions related to education in later life, she also argued that critical educational gerontology is not the answer. This is because despite critical theory's interest in exposing distortions and constraints, it also runs the risk of providing a partial and somewhat distorted view of human experience, and thus, the construction of emancipation and empowerment can become oppressive. Another issue put forward by Withnall (2010) was that critical educational gerontology leaves no room for expressive education for older adults; since it advocates an emancipatory education that has an a priori goal, it ultimately functions to emphasize an instrumental type of education. Withnall (ibid.) also highlighted other definite limits that characterise the critical perspective. For example, it cannot explain the importance of activities fostered by the Elderhostel movement in the United States, or of education groups for older adults organized in England, which often operate without guidance. Withnall (ibid.: 95) thinks that this is the case because 
"participants in these types of activities certainly could not be described as older people trying to understand why they are marginalised". At the same time, she has also pointed out that the fact that older adults are all too often viewed by critical educators as having no power might not correspond well to reality since learners might have power in other social contexts. Hence, she concluded, a reference to people without power is a generalized statement which may not correspond to the facts. Withnall (2010: 116) therefore advocates that 'an alternative formulation might be to think in terms of 'longlife' learning that would straddle economic, democratic, personal and other concerns across the life course in an inclusive way'. This is possible, in her view, if learning is perceived as a broadly based endeavour that incorporates the need for economic progress and social inclusiveness in tandem with the recognition of individual desires for personal development and growth as people age.

Within this debate on gerontology, Formosa $(2002,2012)$ has stood out by defending critical gerontology and at the same time having developed an analysis that advocates the renewal the field of educational gerontology and demonstrate its current relevance. Indeed, throughout his work Formosa assumes that critical educational gerontology needs to be renovated since it appeared more than two decades ago in a context of modern capitalism in which social inequality was based on social class and social policy on ageing was more or less solely preoccupied with securing an adequate retirement pension for older persons. At present, as Formosa (2011) underlined, we are living in the time of late modernity, which created flexible forms of organization and finished with neo-corporatist relations between the state and labour. Given such a backdrop of changing reality, critical gerontology should be renewed so that it "rediscovers its liberatory spark in an excessively globalised and individualised world" (ibid.: 317). To accomplish this goal he makes four key proposals in the hope that critical educational gerontology "engage[s] more extensively in overturning the numerous chimeras that currently pass as justice, freedom, autonomy, and democracy" (ibid.: 326). The key proposals included "a transformative rationale that challenges the cultural hegemony of neoliberalism, the centrality of directive educators, embedding geragogy in a critical epistemology, and a praxeological engagement with historically accumulated concepts and practices" (ibid.: 317 ).

\section{CONCLUSION}

Adult education encompasses a wide range of practices and the discussion of concepts such as individual empowerment and social emancipation is extremely relevant to the field. Indeed, education is not a neutral activity (Freire, 2000), and hence it is necessary to make a stand as regards its values and goals. Critical gerontology, as endorsed by Glendenning and Battersby (1990) and Formosa (2012), aims precisely for the empowerment and emancipation of older adults within the framework of a liberating education. In a world where older adults are affected by a different range of social inequalities, it is increasingly clear that education must allow a critical and radical pathway. Whilst some limitations of 
critical educational gerontology have to acknowledged, the potential of this field is not to be underestimated, especially in view of the coming of new forms of social inequality in later life. As Cusack (2000) argued, the marginalization of older adults is starting to be conceived and seen not only in terms of social class and economic, cultural and social factors, but also in terms of the marginalization that retired individuals may experience by being retired, by being of a certain age, and being excluded from the sphere of economic production. Indeed, older learners are the target of age discrimination and prejudices (ageism), as they are labelled with stereotypical images to the extent that the negotiation of people' identity grow more difficult with age. Critical trends in late-life learning may thus continue to mitigate against such forms of injustices, not forgetting, however, that critical educational gerontology "will be continuously a work-in-process, and there is still much work to be done" (Formosa, 2011: 327).

\section{ACKNOWLEDGEMENTS}

This work was supported by National Funds through FCT - Fundação para a Ciência e Tecnologia (Foundation for Science and Technology) under the project PEst-OE/CED/UI1661/2014 CIEd-University of Minho, Portugal.

\section{REFERENCES}

Berdes, C. Zych, A. A., \& Dawson, G. D. (Eds.) (1990). Geragogics: European research in gerontological education and educational gerontology. Binghampton, NY: Haworth.

Boström, A-K. (2012). Adult learning in a European context. Journal of Contemporary Educational Studies, 63(5), 154-187.

Boulton-Lewis, G., \& Tam, M. (Eds.). (2012). Active ageing, active learning: Issues and challenges. New York: Springer.

Canário, R. (1999). Educação de adultos. Um campo e uma problemática. Lisboa: Educa.

Cusack, S. (2000). Critical educational gerontology and the imperative to empower. In F. Glendenning (Ed.), Teaching and learning in later life. Theoretical Implications (pp. 61-75). Hants: Ashgate.

European Commission. (2006). Adult learning: It is never too late to learn. COM (2006) 614 final. Brussels: European Commission.

European Commission. (2007). Action plan of adult learning: It is always a good time to learn. Brussels: European Commission.

Findsen, B. (2005). Learning Later. Malabar, FL: Krieger.

Findsen, B., \& Formosa, M. (2011). Lifelong learning in later life: A handbook on older adult education. Rotterdam, the Netherlands: Sense Publishers.

Finger, M., \& Asun, J. M. (2001). Adult education at the crossroads: Learning our way out. Leicester: Zed Books/NACE.

Foley, G. (2004). Dimensions of adult learning: Adult education and training in a global era. Berkshire: Open University Press.

Formosa, M. (2000). Older adult education in a Maltese University of the Third Age: A critical perspective. Education and Ageing, 15(3), 315-339.

Formosa, M. (2002). Critical gerogogy: Developing practical possibilities for critical educational gerontology. Education and Aging, 17(1), 73-85.

Formosa, M. (2005). Feminism and Critical educational gerontology: An agenda for good practice. Ageing International, 4(30), 396-411. 


\section{VELOSO \& GUIMARÃES}

Formosa, M. (2007). A Bourdieusian interpretation of the University of the Third Age in Malta. Journal of Maltese Education Research, 4(2), 1-16.

Formosa, M. (2010a). Universities of Third Age: A Rationale for Transformative Education in Later Life. Journal of Transformative Education, 8(3), 197-219.

Formosa, M. (2010b). Lifelong learning in later life: The Universities of Third Age. The LLI Review, 5, $1-12$.

Formosa, M. (2011). Critical educational gerontology: A third statement of first principles. International Journal of Education and Ageing, 2(1), 317-300.

Formosa, M. (2012). Critical geragogy: Situating theory in practice. Journal of Contemporary Educational Studies, 63(5), 36-54.

Formosa, M. (2014). Four decades of Universities of the third age: Past, present, future. Ageing and Society, 34(1), 42-66.

Freire, P. (1972). Pedagogy of the oppressed. Hammondsworth: Penguin.

Freire, P. (2002). Making history: Education for the future. In A. Darder (Ed.), Reinventing Paulo Freire: A pedagogy of love. Cambridge, MA: Westview Press.

Freire, P. (1985). The politics of education: Culture, power and liberation. New York: Bergin and Garvey.

Freire, P. (1997). Pedagogy of the heart. New York: Continuum.

Freire, P. (2000). A importância do ato de ler em três artigos que se completam. São Paulo: Cortez.

Freire, P. (2005). Pedagogia da Autonomia. Saberes necessários à prática educative. São Paulo: Paz e Terra.

Glendenning, F. (1985). Education for older adults in Britain: A developing movement. In F. Glendenning (Ed.), Educational gerontology: International perspectives (pp. 100-141). Beckenham, Kent: Croom Helm.

Glendenning, F. (1990). The Emergence of educational gerontology. In F. Glendenning \& K. Percy (Eds.), Ageing, education and society: Readings in educational gerontology (pp. 13-23). Staffordshire: Association of Education and Ageing.

Glendenning, F., \& Battersby, D. (1990). Why we need educational gerontology for older adults: A statement of first principles. In F. Glendenning \& K. Percy (Eds.), Ageing, education and society: Readings in educational gerontology (pp. 219-231). Staffordshire: Association of Education and Ageing.

Glendenning, F. (2000). Some critical implications. In F. Glendenning (Eds.), Teaching and learning in later life: Theoretical implications (pp. 13-24). Hants: Ashgate.

Hake, B. J. (2012). Intergenerational learning environments in community contexts. In S. Krasovec \& M. Radovan (Eds.), Intergenerational solidarity and older adults' education in community. The Third Conference of the ESREA Network on Education and Learning of Older Adults (pp. 56-64) Ljubljana: Znanstrena zalozba Filozofske fakulteta.

Havighurst, R. J. (1954). Flexibility and the social roles of the retired. The American Journal of Sociology, LIX, 309-311.

Jarvis, P. (2012). Wisdom and the quest for meaning. Intergenerational solidarity and older adults' education in community. In S. Krasovec \& M. Radovan (Eds.), The Third Conference of the ESREA Network on Education and Learning of Older Adults (pp. 20-30). Ljubljana: Znanstrena zalozba Filozofske fakulteta.

Krašovec, S.. \& Radovan, M. (eds.) (2012). The Third Conference of the ESREA Network on Education and Learning of Older Adults. Ljubljana: Znanstrena zalozba Filozofske fakulteta.

Lemieux, A., \& Martinez, S. M. (2000). Gerontagogy beyond words: A reality. Educational Gerontology, 26(5), 479-98.

McClusky, H. Y. (1974). Education for ageing: The scope of the field and perspectives for the future. In S. Grabowski \& W. D. Mason (Eds.), Learning for ageing (pp. 324-355). Washington, DC: Adult Education Association of the United States of America.

McNair, S. (2009). Demography and lifelong learning: Inquiry into the future for lifelong learning (IFLL Thematic paper 1). Leicester: NIACE. 
Percy, K. (1990). The future of educational gerontology: A second statement of first principles. In F. Glendenning \& K. Percy (Eds.), Ageing, education and society. Readings in educational gerontology (pp. 232- 239). Staffordshire: AEG.

Peterson, D. (1990). A history of education of older learners. In R. Sherron \& D. Lumsden, Introduction to educational gerontology (pp. 1-21). New York/Washington/Philadelphia/London: Hemisphere Publishing Corporation.

Shor, I., \& Freire, P., (1987) A pedagogy for liberation - Dialogues on transforming education. New York: Bergin and Garvey.

United Nations. (2002). United Nations Madrid International Plan of Action on Ageing. New York: United Nations.

Veloso, E. (2007). As Universidades da Terceira Idade em Portugal: Um contributo para a análise da sua emergência. Revista Portuguesa de Pedagogia, 3, 263-284.

Veloso, E. (2011). Vidas depois da Reforma. Políticas públicas no contexto português e práticas educativas numa Universidade da Terceira Idade em Portugal. Lisboa: Coisas de Ler Edições.

Veloso, E., Guimarães, P., Martins, F., Silva, D., \& Faria, M. (2011). Elderly, education, intergenerational relationships and social development. Proceedings of the 2 nd Conference of ELOA. Braga: Universidade do Minho/Cied.

Weiss, R. S., \& Bass, S. A. (2002). Introduction. In R. S. Weiss \& S. A. Bass (Eds.), Challenges of the third age: Meaning and purpose in later life (pp. 3-12). New York: Oxford University Press.

Withnall, A. (2000). The debate continues: integrating educational gerontology with lifelong learning. In F. Glendenning (Ed.), Teaching and learning in later life. Theoretical implications (pp. 87-97). Hants: Ashgate.

Withnall, A. (2002). Three decades of educational gerontology: Achievements and challenges. Education and Ageing, 17(1), 87-102.

Withnall, A. (2010). Improving learning in later life. London: Routledge.

\section{Esmeraldina Costa Veloso}

Department of Social Science of Education, Institute for Education

Minho University

Portugal

Paula Guimarães

Institute of Education

University of Lisbon

Portugal 



\section{E-LEARNING: AN OPPORTUNITY FOR OLDER PERSONS}

\section{INTRODUCTION}

Information and communication technologies (ICT) were placed at the core of programmes and initiatives of the 'Lisbon agenda' of the European Commission. The eEurope Active Plan, one of the subsequent initiatives, encompassed a series of short-term plans seeking to integrate ICT into every aspect of economic, social and political life in the European Union (EU). One proposal in this plan was the 'e-Learning Initiative', a political declaration of objectives aimed at incorporating ICTs in education (Salajan, 2007). Consequently, several programmes and initiatives were funded by the EU to improve integration, infrastructure, equipment, and basic education in ICT.

In connection with the Plan's proclamation of specific educational objectives, various expectations regarding e-learning have been made central in public policies, to the extent that e-learning is now a key issue in the debate on lifelong learning. The ability to pursue lifelong learning is a prerequisite for participation in the modern knowledge society, in which 'knowledge' is considered to be a main resource. Due to increasing mediation, lifelong learning is becoming ever more important for every single person, not only regarding their occupational careers and prospects, but also with respect to their personal lives. As a technically supported and customizable learning method, that can be used independent of time and location, e-learning arises as an innovative learning tool that fits several different lifestyles (Kimpeler, 2010). However, one has to investigate whether e-learning is actually an appropriate method for all age groups. This chapter focuses on a certain age group in the field of adult education which is getting ever more attention throughout Europe due to demographic changes - namely, older persons.

\section{ICT AS A LEARNING FIELD}

There is neither a clear definition of nor a consensus on what age a person has to be to belong to the target group of 'older persons' (Findsen \& Formosa, 2011). The age limit is used inconsistently. Statistics issued by Eurostat, for example, apply the term 'older media users' to people between the age of 55 and 74 (Seybert, 2012). Furthermore, the group is not homogeneous, and it is important to keep in mind that that phase of life labelled 'older age' may be subdivided into different phases during which a person's needs and prospects change. Older adults usually decide for themselves whether they want to participate in further education or not on the basis of their motivation, learning experience, health status, and interests. 
Moreover, it is important to take into account both beneficial and impeding factors, such as the social environment, financial resources, and regional integration (AlaMutka \& Punie, 2007).

Despite the heterogeneity of this group, what older persons have in common is that they are faced with manifold challenges, both on personal and social levels, challenges that influence their immediate life situations. They also share certain learning initiatives - namely, learning how to cope with ageing, health and prevention; deepening and broadening their knowledge; competence transfer; postprofessional engagement; generational dialogue/intercultural dialogue; and new technologies (Stadelhofer \& Marquard, 2008). Notwithstanding, the field of "new technologies' is only one of many learning areas. With respect to older adults, it is a central task of education providers throughout Europe to offer diverse programmes - such as political, social or cultural education - to promote knowledge regarding economic, social and political topics, and also to foster the interest of that target group to actively participate in society (ibid.). Considering that ICTs are by now existent in almost all social areas, it is self-evident that older adults need to learn about 'new technologies' in order to be able to continuously participate in society (Schulz, 2011). In many ways, the learning area of 'new technologies' constitutes the greatest possible intersection of the personal implications of further education or lifelong learning as a basic need and of the necessities of a globalized knowledge society (Kimpeler et al., 2007).

\section{OLDER ADULTS AND MEDIA USE}

Since older adults tend to learn in non-formal rather than formal settings, a key question arises is in how far ICTs actually influence their daily life and whether this is in fact perceived as a learning area. Statistical research showed that a large majority of households and individuals in the EU27 uses the internet in everyday life (Seybert, 2012). In 2012, 70\% of individuals in the EU were using ICT once a week. Regarding internet access, there is an imbalanced gradient between Member States, which ranges from $90 \%$ of households in the northern countries (e.g. Denmark, the Netherlands, Luxembourg and Sweden) to below $55 \%$ in the south (e.g. Bulgaria, Romania or Greece) (ibid.). Comparing the age groups, there is a significant gap in ICT usage: only $42 \%$ of individuals aged between 55 and 74 were regular users (ibid.). In addition, the gender gap increases with age. Noticeably, fewer women than men were among the older age groups using ICT. Even though the number of older people using ICTs is much lower than that of younger people, this is not simply explained as an age effect. Rather, this difference also arises as a cohort effect in the usage of ICTs. Older adults are at a disadvantage because they were introduced to computers and modern ICTs at a later point in their lives. It can be assumed that in the near future, due to the younger generation taking over the jobs of the older generation, ICTs will be used a lot more frequently in later life (van Eimeren \& Frees, 2011).

As regards the type of activities carried out on the internet, age differences seem to be marginal at first glance. Studies show that, throughout all generations, 
the internet is used the most for 'communication via e-mail' and for 'information search'. In 2012, for example, the percentage of internet users communicating by e-mail varied slightly from $86 \%$ in the age group of the $55-74$ year-olds to $92 \%$ in for those aged in the 16-24 cohort (Seybert, 2012). The age groups also differ in their internet usage behaviour. While the older generation uses the either-or-logic when watching television, listening to the radio or using the internet, the younger generation tends to watch less television, but manipulating several different devices simultaneously (van Eimeren \& Frees, 2011). The presence of 'hard' criteria (e.g. hardware, internet connection) is insufficient as the sole distinction between digital natives and digital immigrants. Irregular users often only have a very basic knowledge of the computer or the internet itself. Their knowledge regarding more advanced digital topics or applications of the internet is very limited. Hence, 'soft' criteria, such as media competency, explain better the differentiation between nonusers und irregular users. Only a minority of the regular users is actually better informed because of the internet. Most internet users - especially the older ones only gain information and knowledge when going online on the internet, even though such information is available in the traditional media (e.g. television, radio, and print media) (ibid.).

It is, however, noteworthy that information that is disseminated at great speed and in high quantity via the internet is not quality assured. For that reason, it is important to assess such information critically. Teaching media competencies therefore include teaching technical skills as well as critical reflection of contents. Older adults use the internet mainly for everyday tasks (e.g. shopping, recreational activities, hobbies) and self-studies. Hence, it is important to know how to navigate through the internet and to evaluate the information. This is where new tasks for adult education are to be found (Stadelhofer \& Marquard, 2008).

\section{E-LEARNING IN TEACHING AND LEARNING SITUATIONS}

How can the elements of e-learning be integrated into teaching and learning situations, and what is to be expected of e-learning in the context of education for older adults? To answer such questions, it is necessary to define 'e-learning'.

\section{e-Learning as a Diffuse Term}

The term e-learning is frequently used whenever learning with new media is discussed. The term 'e-Learning' or 'electronic learning' was established in the 1990s, when teaching and learning methods became more varied through the introduction of computer- or internet-based media (Kimpeler, 2007). Even though the term is still comparatively young, it has a strong history of utilisation. Inspired by the second generation of online software, the term e-learning 2.0 is not simply used whenever dealing with digitally stored information that are disseminated through the network or with the use of tutorials or learning platforms (e-learning 1.0). It is also utilised when dealing with learning environments that make use of the instruments of the social web, and therefore, of its interaction and 
communication features. The term e-learning 3.0 is used when mobile devices are involved or when an augmented reality is constructed (Rippien, 2012). To summarise, the term e-learning has to be employed within the context of its time dependency because the possibilities of media-supported teaching and learning are dependent on the always changing technological development (Kimpeler, 2010).

It should also be remembered, that the term e-learning is increasingly being criticised and sometimes it is demanded that it should be abandoned altogether. The lack of a clear definition of the term has been said to have a negative impact on learning offers supported by media, because it implied that learning as such was 'electronic' (Rippien, 2012). Therefore, the term sometimes evokes negative connotations among both teachers and learners. Many educators also avoid using the term even if their teaching is supported by electronic technology (Bachmann et al., 2009). Nevertheless, the term 'e-learning' is still widely used. A broad use of the term allows subsuming all forms of teaching and learning in which digital media play a functionally crucial role and are used to support the learning process (Rippien, 2012). Due to this extended use of the term, the focus is not only on institutional and non-institutional learning situations and places of learning, but also on informal learning as well as a variety of learning contents and teaching or learning methods (Georgieff, 2007).

\section{Different Forms of e-Learning}

Even though the understanding of the term e-learning is broad, the question of how this field can be specifically integrated into teaching and learning situations arises. Georgieff (2007) differentiated between two characteristic forms of e-learning. In 'associative e-learning', the main focus lies on the preparation and distribution of multimedia-based learning material. By using ICTs, regional distances between teacher and learner can be bridged. E-learning also supports a flexible learning process. The pace of learning and the contents can be adapted to the need of the individual. In this form, e-learning is used to simulate regular class-based training (Kimpeler, 2010). In 'process-oriented e-learning', new media are used to arrange and direct learning processes. The learner has the opportunity to determine his or her own learning processes and new communication and cooperation tools move into focus (Georgieff, 2007). The functions of media in e-learning are manifold and comprise the full range from information retrieval, learning-related communication between teacher and learner, or mediation of didactically structured learning units up to the design and production of self-created content and collaborative learning. The use of media ranges from simple websites for providing information to the development and use of audiovisual and interactive learning units in virtual spaces.

However, in the actual teaching and learning practice, 'hybrid forms' of elearning are often used to combine the traditional forms of teaching with virtual and digital elements of diverse media. In the case of so-called blended learning, different possibilities of e-learning are used as a supplement to traditional teaching and learning methods (based on the presence of the learner and the teacher) (Kimpeler et al., 2007). The possible use and the fields of application of e-learning 
are manifold; they reach from serious games in schools, virtual universities, corporate e-learning or e-collaboration and e-training in companies to its use in further education for older people. This shows that e-learning is applied in all areas of education (Kimpeler, 2010).

\section{Benefits of e-Learning}

Older adults arise as a target group of education providers because they constitute a highly heterogeneous group, and therefore, the process of approaching them seems rather burdensome to many providers (Georgieff, 2007). However, when education providers who specialise in working with older adults are asked about the benefits of using ICT in late-life learning, its benefits are clearly spelt out. The main advantage is the acquisition of new potential learners. The currently rather low participation rate of older adults in further education and the societal development in relation to the demographic change may explain why educational institutions focus strongly on opening up new participant segments. Another benefit of teaching with the support of ICTs is that teaching becomes independent of time and location (Šemberová, 2008). Classic further education programmes offered by public institutions have fixed venues and schedules but older learners may not be mobile enough to get to the venue (Schulz, 2011). Indeed, using ICTs and elearning improves access to learning for people with limited mobility or transportation options (Ala-Mutka and Punie, 2007).

E-learning also has the potential of meeting the specific needs of older learners. ICTs can balance age-related constraints, such as hearing issues or limited vision, while at the same time training motor skills through the use of diverse new media. At the same time, teaching-learning arrangements based on technical support can be flexibly adjusted to the individual needs of the learners. Materials for selflearning, specific e-learning applications and informal online study groups, all enable learners to learn at their own pace. This is a significant benefit since older learners on average take longer when learning new topics (Ala-Mutka \& Punie, 2007). Besides allowing for adaptation to the individual cognitive performance, computer or internet based material for self-study also enables participants to set individual goals and control their aspiration level. This way, differences in previous knowledge can be compensated. The use of e-learning allows for an internal differentiation within the participants' heterogeneity, which in turn may increase client satisfaction (Schulz, 2011).

Further education is not only seen as a possibility for older learners to increase their knowledge and competencies, but also to keep their minds active and to get in touch with other people. The quest to teach others and to pass on knowledge and experiences is another reason for older people to participate in further education. Of course, Web 2.0 offers a range of possibilities for this (Ala-Mutka \& Punie, 2007). The interactive and cooperative elements supporting communication (email, forums, chats, videoconferencing) are attributed a socially integrative, crossgenerational and cross-border potential. Since cooperative forms of the use of ICT are not yet very common among older adults, it warrants that institutions of further 
education offer courses and counselling in this area, in particular with a focus on this specific target-group (Stadelhofer \& Marquard, 2011).

\section{EXISTING E-LEARNING OPPORTUNITIES FOR OLDER PERSONS}

To what extent are e-learning programmes of actual interest to older people? This section takes a look at existing e-learning programmes that are rather associative or content-oriented, followed up by a focus on process-oriented versions and hybrid forms of ICT learning.

\section{Existing Opportunities of e-Learning Programmes}

Due to the broad range of possible applications of e-learning, the potential for differentiation regarding potential groups of users is remarkably high. In order to let the potential of e-learning unfold fully (that is, to enable the learners to realise their own ideas and goals), certain requirements have to be met (Georgieff, 2007). Since e-learning is a tool that can be used in various and highly customizable ways, a differentiated market for e-learning programmes has developed (typical products include computer-based and web-based trainings or learning and knowledge portals). Nevertheless, so far hardly any research has been done on the specific demands of older adults regarding e-learning. Kimpeler and colleagues (2007) investigated in how far the existing developments and offers of e-learning products on the market already account the specific needs of 'children' and 'older adults'. As mentioned before, the target group of older people is highly heterogeneous. It is therefore not surprising that the market for e-learning products for this target group is less transparent. At present, there are hardly any e-learning offers available for older adults and the marketing measures taken by the providers appear to be rather restrained (Georgieff, 2007).

In contrast to the market of e-learning for older persons, the market for children and adolescents is much more transparent with regard to providers, intermediary institutions, and the range of products offered. The broad assortment of providers (e.g. schoolbook publishers, software developers, companies, and non-profit institutions) is reflected in a wide spectrum of products (e.g. computer games, educational software and edutainment offers). Rather conspicuous is the fact that the range of products is highly diversified and even very specialised products produced in small quantities are considered to be promising. This may indicate that not only non-profit, but also commercial goals are pursued. However, in this case profit maximisation does not seem to be the main objective, but rather, long-term customer retention (Kimpeler et al., 2007). Furthermore, an analysis of the market shows that the few products available targeting older adults show little variance compared to the products for children and adolescents. They mainly focus on media competency, and therefore, on teaching how to handle electronic media. In addition, there are some online English courses especially for older people. The problem seems to be that those topics which are of interest to older learners (e.g. coping with ageing, health, nutrition, or cultural history) are hardly reflected in 
either the product development or the marketing strategies of the providers. The few existing products are rarely compatible with the interests and needs of older learners. This may be a reason for the low demand for such products among older adults (Kimpeler et al., 2007).

\section{Integration of e-Learning into Educational Programmes}

Contrary to the content-oriented variants of e-learning products, process-oriented versions and hybrid forms (blended learning) use new media to structure and guide learning processes. In the case of distance learning, different technical media (synchronous and/or asynchronous) are used to bridge location and time differences between teachers and learners. Learning communities, on the other hand, are informal study groups that use the communication possibilities of new media to get into contact and to interact with one another. The exchange of knowledge and experience does not happen face-to-face, but through modern ICTs (Kimpeler et al., 2007).

The opportunities offered by integrating technological tools into organised educational arrangements are being noticed by many educational providers. Schulz (2011) underlined that e-learning has become a fixed element within universities and companies. The field of further education has also changed significantly due to new technologies. Curricula and educational contents can be downloaded worldwide from libraries or databases via the internet and there is an increasing amount of online offers of further education, blended learning, or virtual study networks (Stadelhofer \& Marquard, 2008). Thus, ICTs offer not only the option to prepare and edit learning contents in various ways - but also allow creating different learning environments. Although the use of the term e-learning is being criticised, there still seems to be a broad consensus that the quality of education can be improved by using technologically supported tools (Šemberová, 2008).

Not least because of the rather high funding of pilot projects, one finds extensive research on the use of e-learning in university contexts (Kimpeler, 2010). Results show that media-supported learning opportunities, due to their high potential regarding customised and flexible learning, have a positive impact on the implementation of diversity strategies. In reference to a lifelong learning perspective, such strategies are meant to consistently emphasise the diversity of university students as a quality feature of the study courses offered and aim at integrating all age groups (Kerres \& Lahne, 2009). Therefore, at many universities, older adults are given the chance to participate in regular study courses either within the framework of study programmes for seniors or as guest auditors. Of course, existing e-learning offers are also made available to that target group and at the same time universities increasingly offer computer courses specifically for older people, so they can acquire media competencies (Georgieff, 2007). Within the framework of the EU project E-learning in Later Life, Universities of the Third Age and similar institutions educating adults and older people were asked about the use of the internet in seniors' education (Šemberová, 2008). Results showed that $74 \%$ of the interviewed organisations claimed to use the internet in their education 
and learning activities. Table 6.1 shows that the intensity in which ICTs are integrated into courses for older adults is expendable.

Table 6.1. Usage of the internet in seniors' education

\begin{tabular}{lcccccc}
\hline & Spain & Slovakia & $\begin{array}{r}\text { Czech } \\
\text { Republic }\end{array}$ & Germany & Finland & Mean \\
\hline $\begin{array}{l}\text { Courses on the } \\
\text { internet }\end{array}$ & 65 & 78 & 66 & 67 & 49 & $\mathbf{6 3 . 2}$ \\
\hline \begin{tabular}{l} 
Internet search \\
\hline $\begin{array}{l}\text { Platform for self- } \\
\text { presentation }\end{array}$
\end{tabular} & 53 & 22 & 63 & 44 & 60 & $\mathbf{4 8 . 4}$ \\
\hline $\begin{array}{l}\text { Online distant } \\
\text { education }\end{array}$ & 12 & 0 & 3 & 11 & 0 & $\mathbf{2 9 . 8}$ \\
\hline $\begin{array}{l}\text { Blended learning } \\
\text { Internet for } \\
\text { communication }\end{array}$ & 29 & 0 & 28 & 22 & 0 & $\mathbf{1 5 . 8}$ \\
\hline $\begin{array}{l}\text { Learning platforms } \\
\text { (e.g. Moodle) }\end{array}$ & 12 & 35 & 19 & 11 & 0 & $\mathbf{1 9 . 6}$ \\
\hline Others & 6 & 11 & 6 & 11 & 0 & $\mathbf{6 . 8}$ \\
\hline
\end{tabular}

Source: Šemberová (2008)

Although ICTs have not yet become a fixed element in late-life learning, it has to be emphasised that older adults who participate tend to have above-average experience in the use of new media (Šemberová, 2008).

Researching existing e-learning programmes in Germany offered by universities, church-related institutions, senior citizens' associations, clubs, and self-help groups, Kimpeler and colleagues (2007) found that few programmes target older persons. Although such programmes are commendable they are more akin to pilot schemes of an experimental nature. This implies that e-learning is not having a significant impact on the education of older people (Georgieff, 2007), and that the potential of e-learning in the field of seniors' education has not been exhausted yet, even though existing research shows that older adults are interested in e-learning (Kimpeler et al., 2007). More campaigns are needed in Europe to introduce ICTs to older people. When doing this, it is important to ensure that the contents meet the interests of older learners and to support them in learning the new material (Stadelhofer \& Körting, 2011). Assuming that older learners who frequently participate in education are especially open to age-heterogeneous study groups, it has to be kept in mind that such educational programmes should be part of analysis, even though they do not explicitly focus on older persons. It is always a balancing act when age-homogenous courses are offered because they may lead to a stigmatisation of older adults. In technology-based courses, it seems to be advisable to group people with similar knowledge backgrounds. There is no doubt that age heterogeneity can constitute an extensive source of enrichment for a study group that includes older people (Ala-Mutka \& Punie, 2007). 


\section{PROBLEMS CONCERNING THE USE OF E-LEARNING IN EDUCATION SETTINGS FOR OLDER PERSONS}

Infrastructural problems are still the main barrier for older people who are interested in participating in e-learning. Thus, the e-learning project 'learning while aging' (target group: older adults with limited mobility) reported that when a course was offered providing twelve places, 25 potential participants showed an interest, but only nine of them had a sufficiently fast internet connection (Schulz, 2011). This shows that not only the high cost of the hardware presents a barrier, but also limited access to broadband internet connection (ibid.). It is therefore important to enhance learning opportunities and computer access in local centres in order to encourage and support those who don't have their own equipment (AlaMutka \& Punie, 2007). In this respect, one must not neglect that specific locallyrooted educational environments may not only offer technical equipment, but can also supply an infrastructure that allows for and promotes learning efforts, and that takes into account the preferences and needs of the participants (Schulz, 2011). At the same time, learners could be supported in their use of ICTs and they could seek assistance whenever problems occurred (Ala-Mutka \& Punie, 2007). The production of affordable products and applications is another important factor in guaranteeing access throughout all age-groups and social classes, and in avoiding social exclusion (Stadelhofer \& Körting, 2008).

Compared to classical face-to-face educational settings, e-learning requires other competencies (Schulz, 2011). A learner who is supposed to use e-learning independently has to have a certain degree of computer literacy. Most European adults acquire their skills outside organised settings by teaching themselves or by seeking informal support. Social networks play a big part in this. Older adults with no computer or internet experience prefer formal settings. It is therefore not surprising that education providers initially focus on these needs and try to cover that demand first (Georgieff, 2007; Kimpeler et al., 2007). Yet, in doing so, they usually only reach those older adults who already value education. For all others, content-oriented e-learning programs seem to be a good alternative to acquire computer literacy, provided that these programmes are designed for that specific target group. In addition, it is important that sufficient information on e-learning products is made available through traditional media (Ala-Mutka \& Punie, 2007).

Due to the lack of programmes aimed at specific target groups, older adults are frequently faced with additional problems - for example, the font is too small or the user interface is confusing (Ala-Mutka \& Punie, 2007). When setting up programmes for older adults one must ensure that the technical design ought to be such that it cognitively takes a backseat and that it does not constitute a permanent obstacle. Furthermore, the technical environment should be limited to the essential features, and hardware and software should be error-friendly and foolproof (Kimpeler et al., 2007). In order to prevent the situation that the used terms are not understood (either due to language issues or because a specific computer language is used), comprehensive language needs to be used (Ala-Mutka \& Punie, 2007). 
The structures of e-learning programmes are often very different to the education and learning routines of older people. Traditionally, further education is based on verbal and spontaneous communication, which corresponds more to the habitual media-usage behaviour of older learners. Many e-learning offers require the scriptualization of inputs, even though ICTs offer several alternatives to written texts, such as video chats or podcasts. This leads to media disruption compared to everyday communication because participants are forced to transform their established communication behaviour (Schulz, 2011). It is therefore especially important to pay close attention to the communication preferences of older learners. Tutorials by trained tutors or blended learning formats would serve this purpose because, in addition to technically supported communication across distances, they offer face-to-face exchange (Ala-Mutka \& Punie, 2007).

The specification of the target group is a complex matter as it is highly heterogeneous. It is obvious that organisations offering e-learning programmes tend to focus on business areas that are easily accessible (e.g. schools). Adult education institutions seem to have qualms about engaging in e-learning. Among the target group of older persons these inhibitions manifest themselves even more strongly (Georgieff, 2007). Learners - as well as teachers - are challenged by the change that comes with ICT-supported learning environments. The teachers do not function as much as purveyors of knowledge anymore, but only help the students manage the large amount of data provided whilst also accompanying the learning process. This requires the redrafting of existing teaching material which is not only highly time-consuming but also requires computer literacy on the part of the teachers which, in many cases, has to be acquired first (Schulz, 2011).

\section{CONCLUSION AND FUTURE POSSIBILITIES}

If adult education providers and teachers want to be successful in the field, they need to devote themselves to e-learning (not only for older adults). To date, the implementation has in many instances failed due to a lack of specific technicalorganisational competencies, the high technical competence required, and a lack of funds (Formosa, 2013). However new media will become an indispensable part of further education in the long term (Githens, 2007; Kimpeler et al., 2007).

It has to be emphasised that, so far, only pilot studies have been carried out to investigate the design of the ICT-supported learning environments that are needed and requested by older learners. Indeed, there is only limited information on how to build a coherent and organizationally adequate overall system for older persons out of the individual components of e-learning. The current didactic principal seems to directly confront the older people with the material. 'Learning by doing' is the prevailing principle applied to help learners overcome fears and prejudices (Georgieff, 2007). In the near future this will surely become less of a problem, since the next generation is used to working with computers and is more extensively familiar with the new technology.

Nonetheless, an intensification of research is needed to gain more secure information and data. In view of the rapid technological development it is also very 
important for all stakeholders (e.g. software engineers, education providers, and participants) to work together regarding the implementation and further development of e-learning offers for older adults. Due to the short-lived nature of technological innovations, the significance of interdisciplinary research projects increases. An intense exchange between science and practice is of great relevance as well. In this, the scientific supervision of field projects is especially important. Exchange has proven to be a benefit, with local and regional projects being more successful in implementing e-learning when drawing on supra-regional concepts and support, and if they cooperate with educational institutions which are already experienced in using e-learning with older adults (Georgieff, 2007). To spread and increase the active use of the 'best practices' multipliers are needed, who, for their part, need to stay on the ball in view of the rapidly changing technologies.

\section{REFERENCES}

Ala-Mutka, K., \& Punie, Y. (2007). Ageing societies, learning and ICT. Barcelona: eLearning Papers.

Bachmann, G., Bertschinger, A., \& Miluška, J. (2009). E-Learning ade - Tut Scheiden weh? In N. Apostolopoulos, H. Hoffmann, V. Mansmann, \& A. Schwill (Eds.), E-Learning 2009. Lernen im digitalen Zeitalter (pp. 118-128). Münster: Waxmann.

Findsen, B., \& Formosa, M. (2011). Lifelong learning in later life: A handbook on older adult learning. Rotterdam, the Netherlands: Sense Publishers.

Formosa, M. (2013). Digital exclusion in later life: A Maltese case-study. Humanities and Social Sciences, 1(1), 21-27.

Georgieff, P. (2007). Zielgruppenorientiertes eLearning - Ein Angebot auch für ältere Menschen? In S. Kimpeler, M. Mangold, \& W. Schweiger (Eds.), Die digitale Herausforderung. Zehn Jahre Forschung zur computervermittelten Kommunikation (pp. 135-146). Wiesbaden: VS Verlag.

Githens, R. P. (2007). Older Adults and e-learning: Opportunities and barriers. The Quarterly Review of Distance Education, 8(4), 329-338.

Kerres, M., \& Lahne, M. (2009). Chancen von E-Learning als Beitrag zur Umsetzung einer LifelongLearning-Perspektive an Hochschulen. In N. Apostolopoulos, H. Hoffmann, V. Mansmann, \& A. Schwill (Eds.), E-Learning 2009: Lernen im digitalen Zeitalter (pp. 347-357). Münster: Waxmann.

Kimpeler, S. (2010). Lernen mit Online-Medien: E-Learning. In W. Schweiger \& K. Beck (Eds.), Handbuch Online-Kommunikation (pp. 364-384). Wiesbaden: VS Verlag.

Kimpeler, S., Georgieff, P., \& Revermann, C. (2007). Zielgruppenorientiertes eLearning für Kinder und ältere Menschen. Sachstandsbericht zum Monitoring ,eLearning “. Berlin: TAB.

Šemberová, J. (2008). Opportunities and perspectives of lifelong learning in older age: The results of the survey from the project eLearning in Later Life - eLiLL. In C. Stadelhofer \& G. Körting (Eds.), Bulletin of the project e-Learning in Later Life (eLiLL) (pp. 15-21). Ulm: Druckwerk.

Rippien, H. (2012): Bildungsdienstleistung eLearning. Didaktisches Handeln von Organisationen in der Weiterbildung. Wiesbaden: VS Verlag.

Salajan, F. D. (2007). The European eLearning programme(s): Between rhetoric and reality. European Educational Research Journal, 6(4), 364-381.

Schulz, F. (2011): Weiterbildung im Alter entgrenzen. Niederschwelligkeit im eLearning Projekt „LEA- Lernend Altern “. Norderstedt: Books on Demand GmbH.

Seybert, H. (2012). Internet use in households and by individuals in 2012: One third of Europeans used the internet on mobile devices away from home or work. Eurostat. Statistics in Focus. Accessed 15/9/14 from: http://epp.eurostat.ec.europa.eu/cache/ITY_OFFPUB/KS-SF-12-050/EN/KS-SF-12050-EN.PDF

Stadelhofer, C., \& Körting, G. (2008). Bulletin of the project e-Learning in Later Life (eLiLL). Ulm: Druckwerk. 


\section{THALHAMMER}

Stadelhofer, C., \& Marquard, M. (2008). The Internet as a chance for continuing education of seniors in a united Europe. In C. Stadelhofer \& G. Körting (Eds.), Bulletin of the project e-Learning in Later Life (eLiLL) (pp. 7-10). Ulm: Druckwerk.

Van Eimeren, B., \& Frees, B. (2011). Drei von vier Deutschen im Netz - Ein Ende des digitalen Grabens in Sicht? Ergebnisse der ARD/ZDF-Onlinestudie 2011. Media Perspektiven, 7(8), 334-349.

Veronika Thalhammer

Institute of Education

University of Tübingen

Germany 


\title{
ANTÓNIO FRAGOSO
}

\section{OLDER ADULTS AS ACTIVE LEARNERS IN THE COMMUNITY}

\author{
INTRODUCTION
}

In the context of lifelong learning, adult education has been abandoning some of its historical and dearer principles of action and theory. Vocational training and similar dimensions concerned with the workers' adaption to the labour market seem to constitute the dominant focus of contemporary adult education. The situation of older learners is even more complex. The scenario of the structural ageing of the European population (particularly serious in Portugal, one of the more "old countries" of the whole world) causes policy makers and practitioners to look for the basic problems - not opportunities - that affect older persons, taking into the account the impact they have in the economy, in a scenario of increasingly downsizing of state expenses. Very frequently the end result is institutionalization: care homes, day-care centres or in-home care services, which usually forces the elderly to live away from their communities. In these institutions, learning can or cannot occur, depending on the bodies that govern the lives of older adults from the moment they step in one of these institutions - private or public.

This chapter makes use of Portuguese statistical data to show the high degree of isolation and the lack of opportunities for older adults to improve their lives in several dimensions - including learning. Adult educators and social workers very frequently - despite their good intentions and even considering constraints coming from the meso structure - deepen the problem they are supposed to fight by, for example, focusing upon those older learners who need less attention. To illustrate this issue, this chapter makes use of field research conducted in a community in the northern Algarve. It argues that most of the action taking place should be recentred, keeping older learners in the community. Community development and education can mean, therefore, an adequate way to improve the quality of life of older persons, mitigating against those trends that remove older learners from their communities. On the other hand, community could benefit from older learners' life experience and knowledge.

\section{OLDER ADULTS AND LEARNING IN PORTUGAL: A GENERAL PICTURE}

In a population of about 10 million inhabitants, the population aged 65 or more years old is of 2,023 million, representing $19 \%$ of total population. In the last decade, the number of older citizens has increased about $19 \%$. Among the elderly, 
the age group that has witnessed a drastic increase is t 80 -plus cohort. The majority of the elderly are women. The ageing index has, in 2010, reached its highest maximum value (INE, 2011): in 1990 the ageing index was 68,1\%, in 2000 102,2\% and in $2010120,1 \%$. But Portugal is a country with significant differences between the coastal (concentrating most of Portugal's population) and the rural inland zones (victims of constant migrations, becoming deserts in terms of population). In the latter, there are even higher ageing indexes, where it is common to have ageing indexes between $200-500 \%$, which means the number of older citizens is from twice to five times higher than the number of children up to 14 years old.

The magnitude of the isolation and loneliness among the elderly is alarming. Today, more than 1.2 million older people live alone or in the exclusive company of other older adults (INE, 2012). This is to say that about $12 \%$ of total inhabitants and $60 \%$ of the elderly live alone $(400,964)$ or in the exclusive company of older citizens $(804,577)$, reflecting a phenomenon which has increased by $28 \%$ in the last decade. The factors that explain these numbers are mainly the increase of average life expectation, desertification of rural areas and the changes in family role. It is important to stress that the majority of the persons living alone are women. For a small country like Portugal, these numbers are shocking.

In 2006 the National Institute of Statistics conducted a survey on the transitions from active life to retirement (INE, 2007). The survey results showed that nearly a fourth $(24.3 \%)$ of citizens aged 50-plus and worked between 40 to 44 years in exchange of a salary or any other type of financial compensation, and about one fifth $(20.6 \%)$ worked between 35 to 39 years - a distribution that applies to both men and women. At the same time, as much as $62 \%$ professed that their key motive to continue working included the need to have a sufficient family income. This shows that not only Portugal has a big and growing number of older adults, but also that they are far from representing an affluent generation. Moderate-level projections are highly surprising. As Gonçalves and Carrilho (2006) point out, in 2050 the total resident population and the children up to 14 years old will decrease, whilst the active population (15-64 years old ${ }^{1}$ ) will maintain a negative variation in this period, representing a loss of about 2 million people in 40 years. The number of persons with 65 years old or more will grow 1.1 million, reaching $31.8 \%$ of the population by 2050 and the ageing index will reach a national average of $243 \%$.

The characterization of older adults in Portugal today would not be completed, however, without a look on learning. A global view on the situation of learning can be grasped analysing the results of the last national survey to education and training of the adults (INE, 2009). General results show a high participation in the diverse kind of education, training or learning, of the individuals who are younger, students, economically active, with higher academic qualifications, with competences in foreign languages and ICT. Participation in formal education, nonformal education and informal learning, or even lifelong learning activities is strongly determined by age (INE, 2009): the group between 55-64 years old has the lowest proportion of participation in every category $(10.8 \%$ in lifelong learning activities, $1.2 \%$ in formal education, $10.1 \%$ in non-formal education and $25.8 \%$ in informal learning). The numbers on informal learning are therefore promising and 
corroborate the view that informal learning might represent an important tool and a valid path to educational interventions among the elderly. The survey also shows that participation in learning varies in the direct ratio with academic level. The higher one's educational background is, the higher the possibilities of engaging in learning. This is, of course, not at all positive when taking into account the academic levels of the Portuguese: a total of $62 \%$ of the workforce could be classified as low-educated with an education of six years or less (OECD, 2001). In $2006,72 \%$ of the adults between 25 and 64 years of age did not attend upper secondary school, and only $14 \%$ had a higher education degree (ibid., 2008).

Languages and ICT showed similar results (INE, 2009): the individuals who know at least one foreign language have a higher probability (about $9 \%$ more) of being involved in lifelong learning activities. Similarly, when compared to those who cannot use a computer, those who master ICT have a higher probability to participate in lifelong learning activities (38\% more), non-formal education $(29 \%$ more) and informal learning ( $27 \%$ more). There is also a strong positive correlation between participation in learning and income level: the higher the monthly income, the higher the percentage of participation in lifelong learning and non-formal learning. Women's participation is higher (a usual pattern in Portuguese society regarding education at general, especially in higher education). Finally and of outmost importance, the survey shows clearly that there is an intergenerational "transmission" of education, in the sense of a strong association between father/mother education and child's education. In short, educating adults has the immediate effect of increasing their children's educational levels.

The above constitutes an overall picture of the situation of older adults, which introduces the following issues: what measures could or should be implemented to ease the strong ageing character of Portuguese society? In this text, we are not only interested in public policies, but also on the role of adult education.

\section{OLDER ADULTS AND LEARNING: THE ROLE OF POLICY}

This general picture of older adults in Portugal depicts a worrying context that surely calls for specific public policies to tackle it. Policies aimed to attract immigrants could be an example. Portuguese citizens traditionally emigrated by the thousands looking for better life conditions and it was not until the 1990s when for the first time the migrations flow was reverted. In that decade the Portuguese State understood that immigrants would play an important role in society and for one decade there were published successive new laws to facilitate migrations, to legalize clandestine migrants, to give them better welcoming conditions, to integrate them in the labour market, etc. So today inhabit in Portugal almost half a million citizens from over one hundred different countries, correspondent to $4.1 \%$ of the population; but this number is no match for the more than five million Portuguese that inhabit in more than a hundred different countries of the world (Rocha-Trindade, 2010). Plus, the very recent collapse of State accounts and the intense economic and financial crisis in Portugal (that forced the Portuguese State to ask for the assistance of European Central Bank / International Monetary Fund / 
European Commission) printed new trends in migrations flows: not only the immigrants are leaving to other countries, as once again Portuguese citizens are leaving the country. According to official data (PORDATA, 2013), during the year of 2011 there was a total of 100,978 Portuguese leaving the country $(43,998$ permanent and 56,980 temporary) and in 2012 that number was of 121,418 (51,958 permanent and 69,460 temporary).

The hopes that immigrants will integrate and at least attenuate the consequences of the structural ageing of Portuguese society seem to be impossible in the moment. If immigration is not a solution to alleviate structural ageing, then the answers given by policy have to be focused in promoting birth-rates. This could be done by providing direct subsidies to families with lower incomes wishing to have two children or more; or providing indirect advantages to these families related to public health or education expenses. Unfortunately, the very few measures that used to exist to support families were simply cut out or dramatically reduced in the last three years, in the context of the Portuguese structural adjustment programme. In the present moment, therefore, there are no political incentives whatsoever to the increasing of birth-rates in Portugal. The future looks gloomy.

To finish this section, we still have to analyse the role of the State as provider of services to older adults, an issue that deserves a small framing introduction. Recent democracy in Portuguese society was built at a counter-cycle when compared to other European countries. The golden phase of the welfare-state found Portugal immersed into a dictatorship regime. The coup d'état that ended it was in 1974 and in subsequent years Portugal tried to build a providing State, roughly when the occidental world was turning to neo-liberal policy - train that Portugal begin to travel in the mid-80s. These fast changes caused that in some areas typical policies from welfare mixed or even live together with typical neoliberal policies (in education this was called by Afonso [1998] as mitigated neoliberalism). In a number of social and educational dimensions, the contracting of civil society organisations to act in the name of the State commenced during the 1980s and increased greatly over the years. This is the case of services to older citizens. Incapable of assuring it, the Portuguese State defined a type of institution (particular institutions of social solidarity) that delivers services of public interest in a contractual basis - the States pays per head for each older citizen that needs such services, but the institution has to provide buildings, equipment's, etc. In terms of policy, Santos (1990) called the attention to the changes this brought to the balance between the State and civil society, claiming the neoliberal state to be, not shrinking, but actually expanding through civil society. But soon there begun a clear policy of institutionalisation of older adults in Portuguese society, that was in practice too much welcomed by private or civil society organisations. In contemporary times, there is no doubt that the level of institutionalisation of the elderly is especially worrying.

The institutions of social support that provide care or related services to the elderly usually consist in care homes, day-care centres, or in-home services (the same institution can provide all three types of services). In 1991 there were 2,339 institutional settings where older adults lived; in 2001 there were 3.876, an increase 
of $61 \%$. In 2011 the number rose to 4,832, an increase of $80 \%$ (Gonçalves, 2003)! No wonder, indeed, that more than 800,000 older adults live in the exclusive company of other older citizens. However, more important that knowing the absolute number of the elderly living in institutions is to know who these citizens are. More than half of the elderly living in social support institutions are 80 years old or more and are widows or widowers. Their educational qualification levels are very low (ibid.): the majority are illiterate $(67.1 \%)$ and the remaining have only four years of schooling (30\%). Less than 3\% have more than primary school as academic attainment. The number of residents in paid employment is almost nonexisting. Other dimensions - such as having special needs or the people's economic situation - only reinforce a very crude statement - namely, that these institutions are, generally speaking, warehouses for the poor.

Care homes, day-care centres or similar structures are governed by bodies from the institutions that deliver it, that may vary according to the specific case. But the elderly do not belong to such bodies. They can be "consulted" or "heard" (metaphors sometimes presented as participation), namely regarding the educational activities that are offered; but the main rules that govern their daily lives are not established by themselves nor do they have any participation in it.

It therefore seems that Portugal has a class-divide mechanism that increasingly institutionalizes working-class older citizens, reinforced by an astonishing level of isolation of the inland population in Portugal. Loneliness seems a central motive for older adults that voluntary enrol day-care centres and homes. Politically speaking, it seems strange that Portugal is still in the "phase" of considering institutionalization as a solution, whilst elsewhere policies and services are increasingly focused in the community (Bilsen et al., 2008; Cox, 2005), and there are already several studies that show that community-based services improve significantly the quality of life of the elderly (Chan, 2008).

De-institutionalising would seem an important task to improve the lives of older adults. But an issue remains to be looked at: what was or is the role of adult education in this matter? It seems strange that a country where community development - in Portugal conceived as an important part of adult education (Canário, 1999) - experienced an enormous boost after the 1990s, this has not been able to do enough for older adults. To illustrate some of the difficulties of placing social interventions with older adults in the community, I will analyse briefly research elements from a community in the northern Algarve called Cachopo. These come from a research where community development processes here were studied for the period 1985-2003.

\section{OLDER ADULTS AND LEARNING: THE ROLE OF ADULT EDUCATION}

Cachopo represents a typical rural area of the inland Portugal, where communities suffered the impacts of modernization after the Second World War. These populations migrated strongly to other European countries and later on to urban centres in coastal zones. It is an area of about $200 \mathrm{Km}^{2}$, with a central village that concentrates the few services available. Yet the majority of the populations inhabit 
isolated places or small clusters of houses spread through the field. Sometimes roads are lacking; health services are almost absent; kindergartens are non-existent, schools have been closed because of the lack of children, etc. By the time that the social interventions began in Cachopo - in the middle 1980s -statistic data showed all the main features mentioned above. According to the National Institute of Statistics (INE, 1998; INE, 1999), the population density was very low, with only seven residents per $\mathrm{Km}^{2}$, and $26 \%$ lived in single households. Every ten years the population decreased at a rate of $25-28 \%$. Birth rates were very low (4/00) and mortality rates very high (19/00). The ageing index was extremely high (405\%). If we consider economic activity and unemployment rates for both men and women, the figures were, respectively, $28.7 \%$ and $7.9 \%$. But when one looks only at the women, these percentages changed dramatically, to $10.8 \%$ and $26.7 \%$. This means that of the small 10 percent of the women who have a declared back in the $80 \mathrm{~s}$ an economic activity, $27 \%$ of them were unemployed. Women were forced to stay in their homes taking care of their children and the elderly, suffering from social isolation and economical exclusion. Illiteracy rates (among people above the age of $10)$ were very high (38\%) and the majority of Cachopo's population had completed only primary school (48\%). Only $7 \%$ had completed secondary school and $0,1 \%$ of the population had completed tertiary education.

Community development processes in the area were triggered by a civil society organisation (as it happened in the majority of cases in Portugal - see Silva, 1996). Strongly inspired by participatory research (Hall, 1981; Tandon, 1988) and by community development frameworks (Melo, 1988; Melo, 2000; Reszohay, 1988), the association In Loco started working with the population, using participatory methods and techniques to start the action around community problems and needs. From 1985 to 1991 three different axis of action were defined (In Loco, 2001): socio-educational work with children; training aiming the promotion of work among women; and support to local associations ${ }^{2}$. In each one of these action axis several important interventions occurred. To mention only a few, it was created an infancy animation centre (Fragoso, 2005a), two different training courses that culminated with the creation of two small women's enterprises (Fragoso, 2005b), and two new community associations. Over the years and until today, these processes passed through many different phases (for example, a period when the population started to display their own spontaneous activities) and had significant impacts in several dimensions, that is, in terms of local economy, but also in cultural and social terms. However the points I want to stress in this text go in a different direction

During the period 1985-1991, In Loco was the only institution that was present in this territory. Despite the obvious merits of their work along with Cachopo's population, the association never considered to do something with the elderly. Yet they were in a terrible situation: a significant number living totally isolated without any type of family (usually because of emigration); suffering from various health problems, commonly with no medical assistance at all; alone and without life prospects, etc. But one also has to consider that the historical moment in Portugal produced very different discourse and pre-conceptions about the world. In 
particular, militant discourses that claimed that the intense ageing and desertification of the territory could be stopped if young adults were elected as preferential targets of local action; if locally and trough education and training young adults would be helped to generate their own jobs and economic wealth, then they wouldn't be force to migrate (Fragoso, 2011). This reasoning was, of course, a bit naif and mostly underestimated both the fact that neoliberal policy produces structural unemployment and that community development has its natural limitations. Anyhow, the fact was that during those years young adults and adults were central in Loco concerns - not older adults.

Also in 1991, two important events took place (Fragoso, 2009). First, In Loco was elected as local action group in the context of the LEADER programme. As their team was small, their new responsibilities forced them to stop the direct intervention in Cachopo (and also in other similar areas), substituting it for the local action of in-service trained mediators. Second, it emerged in Cachopo a new association, connected with the Catholic Church, which elected as an action focus the care for the elderly. In this way new care services targeting older citizens begun to be created: first a day-care centre, then in-home services, more recently (2009) a care home. The importance of this work is undeniable. And although literacy was important in a first phase, although in this institution social and cultural animation is provided to the elderly, their central philosophy remains to be catholic charity and assistance. In short, a type of action provided by adult educators or adult education civil society organisations would probably (or hopefully) be done with different inspirations and methods.

At this point, therefore, it is logical to ask why is there a certain tendency for adult education actors and institutions (as in In Loco, which is a well-known association in the field that in Portugal has a deserved prestige) to "forget" the work with older citizens? My speculative answers follow: first, the work with older adults generally implicates simple assistance, like health care or even more basic live dimensions to be looked after. It implicate to deal with frail adults that in some cases do not have any possibility to do wonders when engaged in participatory processes; by the contrary sometimes the only solution is to care and provide some human dignity. Physical and psychological constraints are to be expected from older citizens, especially the ones with advanced age. This is a form of action that has been not the priority of adult educators, more focused in attaining change or social change through education. These aspects are difficult to tackle and represent real limitations to the type of work adult educators like to do. Second, adult education in Portugal - especially the third sector - has been experiencing an increasing instrumentalisation by the state. The State is capable, through indirect control (funding and regulations) to establish the rules of contacted work, not only to guide civil society organisation's work to certain areas - the ones elected as priorities by the State - but also to influence the models and methods of action. Once the dependency ties are created between institutions and the State, a problem arises: they have to change according to State policies changes. In order to survive, civil society organisations have been therefore changing their nature, the type of work being done and sometimes even change their central philosophy - and in this 
process the criteria of considering the needs and community problems as central fatally loses importance:

The social control that is exercised over the [adult education] sector (basically through financing and the specific design of technical instruments) re-directed the CSO's actions; now they are delivering the exact services they are supposed to, according to priorities defined elsewhere that may or may not correspond to the needs and problems of deprived populations. Little space is left for critical action and the former 'enemies' who used to try to fight back are more or less domesticated under the flag of survival. (Fragoso \& Lucio-Villegas, 2008: 28)

These and other explanations had, in any case, consequences: the majority of the work being done with older adults is avoided by adult educators or adult education organisations; and social work institutions or social workers are the ones who take this space of action. Social work is in Portugal a complex, non-unified field of practices. In part, because the type of professionals that make concrete social services come from different fields of knowledge (social service, psychology, sociology, social education or community education, for example) carrying with them different academic backgrounds and thus different approaches to the practice. It seems noticeable that some professionals incorporate in their action principles of adult education and, in some cases, a strong inspiration rooted on critical theory or in authors such as Paulo Freire $(1987,1997)$. The needs of care or assistance are not obviously questioned, but in some models there is truly an effort to have a more structural action towards change. Nevertheless, there are no unified models for social work regarding older adults. Plus, the fragmentation of the thousands of institutions that provides care and services to the elderly makes quite impossible the building of a minimum consensus on action models; and also for the role of education and learning in this context. But all things considered, it seems an undeniable fact that the movement of placing older adults into institutions goes on.

It seems also fair to state that older adults' learning has been a central preoccupation for some adult educators or institutions inspired by adult education. But in this regard a few comments are important. Above I have presented national data on the learning of older adults. From these numbers it is possible to obtain a profile of the typical non-participant in adult education activities in Portugal: nonparticipants have more than 45 years old; an academic background of less than 9 years of schooling; inhabit isolated or weak density population areas; are mainly inactive or professionally low qualified; earn less than $750 € /$ month; do not use computers or internet; know not foreign languages; and, finally, do not have reading habits of books or newspapers. Even if in the past there was an adult education tradition to focus the more needed groups of the population, I argue that in the context of the hegemony of lifelong learning this important feature is being progressively and silently lost. For reasons that are maybe multiple, adult education and adult educators are frequently concerned and working with middle-class participants, leaving aside a plethora of disadvantaged groups. And maybe learning of the older adults could provide a simple illustration: In Portugal, third age 
universities or similar institutions have been assuming an important role when it comes to the learning of older citizens. But like it happens commonly in other countries (see, for example, Formosa, 2012) in these institutions we find mainly middle-class older women - not the non-participants typical of the profile we talked above. Also previous statistics shown in this text show that formal education is not a solution for this problem. However, the statistics show that older adults engage more frequently in informal learning. So a key argument for placing older adult's learning in the community is precisely the possibility to have an educational role amongst the older adults that really need it, as a tool that can foster social change. Disadvantaged older adults are not found in formal educational settings; or in third age universities at general. Surely it is easier to look in the community.

\section{CONCLUDING REMARKS}

The intense ageing of Portuguese society is not going to vanish and, on the contrary, will deepen. The today's inexistence of a policy aiming to tackle the problem is worrying and it will probably create impacts not only for the lives of the elderly, but also for the economy. The recent economic impacts tend to function as pretexts for the increasing character of privatization of Portuguese society, to worsen future scenarios. If the political trend for the privatization of social life (Lima, 2004) it to be kept, then we might expect that working-class, older citizens and similar disadvantaged groups will experience increasing difficulties and a wider gap in their live conditions as compared to the wealthier.

In these conditions it seems urgent to advocate for the de-institutionalisation of older citizens and for a re-focusing on community. This has to be first built politically and the possibilities are various. First, evaluating seriously the real needs for care institutions and constraining the support on these types of services in the measure of the obtained results, at the same time that State support is created to alternative forms and models of community based-care. In this aspect local governments can be very important due to proximity they have regarding the citizens. Also informal carers, for example, deserve some attention. In the moment, their numbers are growing, but most of them are non-certified, non-qualified carers, which can be a source of additional problems. But processes of certification and training of informal carers - where higher education institutions have a saying - to function in communities would surely be important. Measures that look seriously at families are also much needed. There are significant cases of families who discharge the elderly in institutions and we need to know these milieus much more than we do - to both create forms to impede unmoral institutionalisation or to invent support that would allow families to keep and care their relatives in their natural homes. In short, there is much to be done to stop this tendency to institutionalization.

Adult education has to claim spaces and responsibilities for working with older adults and learning. Adult educators are the ones who can defend community based-services and community-based learning for the elderly. To keep older adults in the community means (among many other things) to avoid that their social 
contacts be further constrained and limited to only other older adults. The solution for isolation is not to gather older citizens with other older citizens. Quite the opposite, it is the search for creative ways to bring isolated older adults to contact with people of all ages, which only can be done within the community. Definitely, there seems to be no doubts that the quality of life of older citizens can be kept and improved if community represents their safe space to socialize, learn and live.

\section{AKNOWLEDGMENT}

This chapter was partially possible by the support of the Portuguese Foundation for Science and Technology (FCT).

\section{NOTES}

1 Until recently, active age (15-64) was defined in this interval because compulsory education was only up until 9th grade, whilst retirement age was of 65 years old. Presently, compulsory education has been extended to $12^{\text {th }}$ grade and retirement age increased by one year.

2 Actually, when the action started, there was not a single association in this territory. A significant part of In Loco's team efforts with the local social actors was to create collective structures that included informal groups in the community that later on would be responsible to continue the processes.

\section{REFERENCES}

Afonso, A. J. (1998). Políticas educativas e avaliação educacional. Para uma análise sociológica da reforma educativa em Portugal (1985-1995). Braga: Universidade do Minho/Instituto de Educação e Psicologia/Centro de Estudos em Educação e Psicologia.

Bilsen, P. M. A., Hamers, J. P. H., Groot, W., \& Spreeuwenberg, C. (2008). The use of communitybased social services by elderly people at risk of institutionalization: An evaluation. Health Policy, $87(3), 285-295$.

Canário, R. (1999). Educação de adultos. Um campo e uma problemática. Lisboa: Educa.

Chan, H-T, Cheng, S-J., \& Su, H-J (2008). Integrated care for the elderly in the community. International Journal of Gerontology, 2(4), 167-171.

Cox, C. B. (2005). Community care for an aging society: Issues, policies, and services. New York: Springer.

Formosa, M. (2012). Lifelong education for older adults in Malta: Current trends and future visions. International Review of Education, 58(2), 271-292.

Fragoso, A., \& Lucio-Villegas, E. (2008). Is local development dead? An essay on past elements to think about the future of adult education and development. In A. Fragoso, E. Kurantowicz, \& E. Lucio-Villegas (Eds.), Adult learning and community development. Wroclaw: University of Lower Silesia.

Fragoso, A. (2005a). El triángulo mágico: escuela, familia y comunidad en una intervención con jóvenes de contextos sociales desfavorecidos. XXI Revista de Educación, 7, 81-90.

Fragoso, A. (2005b). Formación e Inserción Profesional: análisis de cinco cuestiones levantadas por la investigación. Diálogos, 41, 33-39.

Fragoso, A. (2009). Desarrollo comunitario y educación. Xàtiva: Diálogos.

Fragoso, A. (2011). Time goes by: An overview of local development trends in Portugal. In A. Fragoso, E. Kurantowicz, \& E. Lucio-Villegas (Eds.), Between global and local: Adult learning and development (pp. 119-131). Frankfurt am Main: Peter Lang. 
Freire, P. (1987). Acção cultural para a liberdade. São Paulo: Editora Paz e Terra.

Freire, P. (1997). Pedagogía del oprimido. Madrid: Siglo XXI de España Editores.

Gonçalves, C., \& Carrilho, M. J. (2006). Envelhecimento crescente mas espacialmente desigual. Revista de Estudos Demográficos, 40, 21-37.

Gonçalves, C. (2003). As pessoas idosas nas famílias institucionais segundo os censos. Revista de Estudos Demográficos, 34, 41-60.

Hall, B. L. (1981). Participatory research, popular knowledge and power: A personal reflection. Convergence, $X I V(3), 6-19$.

In Loco (2001). Formação para o desenvolvimento. Formação/Inserção profissional territorializada. Faro: In Loco.

INE. (1998). Anuário estatístico 1998. Região Algarve. Lisboa: Instituto Nacional de Estatística.

INE. (1999). Inventário municipal região Algarve 1998. Equipamentos, produtos e serviços. Lisboa: Instituto Nacional de Estatística/Comissão de Coordenação da Região do Algarve.

INE. (2007). Dia internacional do idoso. Lisboa: INE.

INE. (2009). Aprendizagem ao longo da vida - Inquérito à Educação e formação de adultos 2007. Lisboa: INE.

INE. (2011). Anuário estatístico de Portugal 2010. Lisboa: INE.

INE. (2012). Censos 2011 - Resultados pré-definitivos. Lisboa: INE.

Lima, L. C. (2004). Adult education as social policy: Reforming and post-reforming strategies in Portugal. In L. C. Lima \& P. Guimarães (Eds.), Perspectives on adult education in Portugal. Braga: Universidade do Minho.

Melo, A. (1988). O desenvolvimento local como processo educativo (impressões e opiniões autoentrevistas). Cadernos a Rede, 2, 58-63.

Melo, A. (2000). Políticas e estratégias culturais para o desenvolvimento local. In L. C. Lima (Ed.), Educação de adultos, Forum II (pp. 17-28). Braga: Universidade do Minho, Unidade de Educação de Adultos.

OECD. (2001). Thematic review on adult learning. Portugal. Country note.

OECD. (2008). Education at a glance. OECD.

PORDATA. (2013). Base de dados de Portugal contemporâneo. Accessed 8/1/13 from: http://www.pordata.pt/Portugal.

Reszohay, R. (1988). El desarrollo comunitario. Madrid: Narcea.

Rocha-Trindade, M. B. (2010). Associativismo em contexto migratório. Migrações, 6, 39-58.

Santos, B. de S. (1990). O Estado e o direito na transição pós-moderna: Para un novo senso comum sobre o poder e o direito, Revista Crítica de Ciências Sociais, 30, 13-43.

Silva, M. I. (1996). Práticas educativas e construção de saberes. Metodologias de investigação-acção. Lisboa: Instituto de Inovação Educacional.

Tandon, R. (1988). Social transformation and participatory research. Convergence, XXI(2/3), 5-18.

\section{António Fragoso}

CIEO-Research Centre for Spatial and Organizational Dynamics

University of Algarve

Portugal 

SECTION 2

PARTICIPATION AND PROGRAMMES 

DOMINIQUE KERN

\title{
7. CONCEPTUAL BASIS FOR LEARNING
}

\author{
Frameworks for Older Adult Learning
}

\begin{abstract}
INTRODUCTION
Learning activities are realised during the whole lifespan in different settings and situations. Older adults do learn too. Research about this "new" public is recent, but several conceptual approaches exist. The aim of this paper is to analyse different positions to identify and argue key-aspects for research on older adult education. This should serve as a base to sustain planners and developers in their efforts to conceptualise learning offers and learning arrangements for older adults. The paper proceeds in a first step a brief presentation of existing concepts and highlights guidelines, and in a second step a comparative analysis shows some shared aspects. The acknowledgement of specificities of education in older age is shared by most all approaches. On the other hand, one can note distinct disciplinary positioning. Based on this analyse, the chapter argues as a conclusion, the importance of three central aspects in relation with the education of older adults: the definition of the public, the identification of the learning needs as well as the reflection about learning settings. By this, reflexion about integration of the nonparticipants in older adult education offers emerge as cross-cutting theme.
\end{abstract}

\section{CONCEPTUAL APPROACHES TO TEACHING OLDER ADULTS}

Older adult education is become a subject of scientific reflexion only in the middle of the $20^{\text {th }}$ century. In the 1950s, in the USA, Donahue (1955) published a first scientific description of a systematic formal setting experience. A group of elderly "asked for a course in which they could learn the technics needed for developing programs to serve the needs of the older people in the community" (Donahue, 1960: 377). The result was an eight-week course entitled "Learning for Longer Living: Practice in Community Service for the Aging" (ibid.). This first USAmerican experience was followed by the conceptualisation of "Educational Gerontology" (Peterson, 1976). In the same period but on the other side of the Atlantic, Bollnow (1962, 1966) and Mieskes (1970) developed theoretical reflections about older adult education. We don't have signs that these first European and US-American researchers have known each others work. We just can note that they did not quote them. These two epistemological evolution lines crossed in the 1980s, creating several hybrid approaches like geragogy critic (Glendenning, 1992), gerontagogy (Lemieux, 2001), German-humanists geragogy (Petzold, 1985). A special position has the French model 'full continuing 
education' (Carré, 1980). It is the only one which does not promote the idea of a special approach for adults based only on the chronological age.

\section{Gerontagogy and Geragogy ${ }^{1}$ : The German Origins}

In his preliminary studies for an education in the old age, Bollnow sets the epistemological base for "Gerontagogy" which is the study of the education of the old human beings ${ }^{2}$ (1962: 393). He argues that "it is not enough to reduce age complaints by medial care and to distract them with occasional entertainment; it is more important to sustain them to cope with their age in a right and meaningful way. This is an educational task"3 (ibid.). Some years later, Mieskes, also German and professor in Education Sciences as well, published a paper about the "pedagogy of the age and of the elderly" (1970: 94). He agreed largely with his colleague in the main orientations but, nevertheless, named his approach Geragogy. This semantic distinction is still in use today as we will see later.

Beyond these differences, the essential finding of these two very close theoretical approaches was the argumentation of specificity of older adults in terms of education compared to younger adults. Though, one notes that a precise definition of the target public is missing. Nowadays, the group of "older adults" has become in fact a very heterogeneous one. But, the reflexion of these first researchers can still be seen as an inevitable base for research on education of older adults founding in education sciences epistemology.

\section{Educational Gerontology Conceptualised by Peterson}

Without referring to these earlier European thinkers, Peterson wrote in 1976 the first article in the journal of the same name about 'Educational gerontology'. He presented 'the state of the art' and fixed a particular orientation of his approach. Peterson's (1976: 62) concept 'educational gerontology' encloses three interrelated aspects:

1. educational endeavours designed for persons who are middle aged and older;

2. educational endeavours for general or specific public about aging and older people;

3. educational preparation of persons who are working or intend to be employed in serving older people in professional or paraprofessional capacities.

The concept is clear. It corresponds to the practice needs and includes the different relevant aspects of gerontological field. By this and by a deepening and differentiation, Peterson laid four years later the foundation on which most successors referred to (1980b: 68). The approach is conceptualised as a gerontological model as the name indicates it clearly. The general aim is to improve the quality of life of older citizens (Peterson, 1976: 62). The spirit of the objective seems to be close to Bollnow's one. But one can already guess the fundamental differences between "improve quality of life" and "sustain them to cope with their age in a properly and meaningful way" (Bollnow, 1962, 1966). While the first one describes a pragmatic and measurable aim (improving quality 
of life) the second one refers to an accompaniment activity aiming an educational process. In fact, as we will see later in this chapter, from an epistemological point of view, Bollnow's and Peterson's approaches refer to the same topic but from a different point of view.

\section{Three Specific Approaches that Use the Terms Geragogy and Gerontagogy}

Various researchers developed approaches for education and training for older adults. From a global perspective, it isn't possible to present an exhaustive list. For this, the research work needs to proceed first in a world-wide systematic enumeration. Without any doubt, this will be an important and intensive task in the future. In the meanwhile, we rely essentially on articles published in the journal "Educational Gerontology" and focus on three distinguish ways for dealing with the topic: 'Critical gerogogy', 'gerontagogy as one part of a dual approach' and 'Geragogy based on German humanistic psychology'. The chosen concepts are just used as examples. The aim is to give an idea of variability of answers for the same basic questions.

\section{Critical Gerogogy}

Referring to him, Glendenning nevertheless makes significant changes on Petersons's model "to clarify it for the British scene" (1989: 123-124). He is distinguishing educational gerontology from gerontological education: the first "deals with the processes of learning for older adults" and the second "embraces teaching about an aging society for those preparing for a professional career in gerontology, for gerontologists undertaking postexperience education, and for the preparation or updating those who are caregivers, whether voluntary or professional, to older people" (ibid.: 123). In a later publication, Glendenning continued his reflection in the direction of a "critical educational gerontology articulated through critical gerogogy" (1992: 18). By this, directive education should be avoided. By the integration of the critical social theory and the critical pedagogy (ibid. p. 13), aims like empowerment and self-fulfilment are set as priorities. Glendenning places the older learners as actors in the learning settings and questions essential educational thematics like the relation between learner and educator.

Further reflection about the approach is provided by Formosa who develops praxeological principles for critical gerogogy (2002: 78). He combines for example the aim 'transformation of ageist social structures' with Paulo Freire's 'pedagogy of the oppressed' (ibid.). He also positions critical educational gerontology in comparison with humanist approaches in adult education (Formosa, 2011: 12). For him, approaches of older adult's education have to be "a work-in-process" and need to be adapted to the changing environments. If "humanist position holds a lot for promise and potential", critical educational gerontology has to keep in mind social realties (e.g. inequality) and the inability of "subjects to work towards the transformation of such realities in individualist and self-directed ways" (ibid.: 17). 
Finally, the author calls the "educational gerontological community" (ibid.) to contribute to epistemological discussions and expresses by this the need of a critical exchange between colleagues.

\section{Gerontagogy as One Part of a Dual Approach}

The name 'Gerontagogy' proposed by Bollnow in 1962 describes the theory of the education of the old human beings. The expression is used by researchers with different language backgrounds, but most of them do not refer to the German original document. They construct their own definitions and approaches. Lemieux (2001) for example contributes to the reflection with a dual model, distinguishing Gerontagogy from Geragogy. Geragogy is concerning here only education and training of older people presenting deficits (Lemieux \& Martinez, 2000: 492). Gerontagogy is concerning older adults without deficits and is defined "as a new hybrid science resulting from the prolific combination of educational gerontology multidisciplinary specialisation in itself - and education of aging" (ibid.: 482). Hierarchy of contributing disciplines is clearly established. The specific ideas for teaching and learning with, for and by older adults, come from sciences of education (ibid.). Gerontagogy is the "study and the educational practice not as part of the aging processes, but firstly, as part of teaching and of learning of people, distinct between each other" (ibid.). Lemieux places his approach called 'gerontagogy' in education sciences, contrary to Robertson who is referring his approach of educational gerontology to gerontology. The article explains later on the signification of this distinction. Even if Bollnow (2001) is not quoted in the articles, Lemieux's definition of gerontagogy contains important elements of the original theoretic base like the anchoring in education sciences. In addition, like Glendenning's work, this approach also underlines the importance of an epistemological foundation.

\section{Geragogy Based on Humanistic Psychology}

In Germany, 'geragogy' was and is still used by several researchers close to practice. However, the signification is mostly much larger than stated by Mieskes (Veelken, 1990: 58) who defined it as the "sum of all scientific statements whose content is related to the educational reality of ageing and old people"5 (Mieskes, 1970: 95). Differences emerge also in the disciplinary positioning. Here, the relation to Education Sciences is not privileged, on the contrary. The express nonaffiliation with adult education is argued for example with the different learning objectives and contents of elderly education (Petzold, 1985: 19). Beyond, this approach of Geragogy is linked explicitly to humanistic psychology, especially to the Gestalt method (Petzold, 1985). 


\section{Full Continuing Education ${ }^{6}$}

Developed in the late 1970 years, this model is not known by non-French-speaking researchers. In fact, it has not been published in an international journal at that time. Although, its particularities make it an interesting contribution to the epistemological discussion on older adult education. The premise of the need of a special educational approach for older people is not shared with the other concepts. Based on an empirical research work, Carré concludes that a special approach for elderly cannot be justified automatically (1980a: 38; 1981: 119). Analysing educational similarities in learning situations of adults of different ages, he finds that the chronological age - the number of years passed since birth - is not the most important variable (1981: 120). Taking into account the institutional (for example University of third age), pedagogical (gerontagogy) and theoretical (educational gerontology) realities, he suggests to consider education of elderly just as a special stage in the development toward a full continuing education (ibid.).

Carré is referring therefore to the French concept of éducation permanente (full continuing education) which describes the idea of an education during the entire adult life, which left some traces also in legislation ( $n^{\circ} 71-575$ from the 16 of July 1971). An essential point in the argumentation of the non-separation of younger and older adults lies in the apprehension of a non desirable institutional separation of education of older adults. Nevertheless, he is aware of particularity of education of older adults (1981: 119). The solution for him is not a special education approach for older adults but a general democratisation, opening access to education for everyone.

This overview of some conceptual approaches for education for older adults gives a first idea of variety. But, despite the obvious differences suggesting diversity (concerning terms for example), the following analyse permits first of all to identify regularities.

\section{OBSERVATIONS: ANALOGIES AND DIFFERENCES}

Generally one can say that all of the concepts share some essential ideas. Differences exist in specific aspects. Nevertheless, as we will see, regarding the epistemological anchorage, two different disciplinary roots appear. In fact, by analysing main disciplinary connections, one can establish a difference between concepts referring more to Gerontology or to Education Sciences. This categorisation is a proposal to be discussed in the scientific community.

\section{Analogies}

All concepts, except Full continuing education, present education for older adults as different from education for younger adults. An argument is the general inadequacy of Knowles' andragogy model for the older adults (Glendenning, 1992: 8 -9). It is interesting to note that this argumentation is based on an empirical reflection. Starting from the practical education work with older adults, for 
Glendenning it is obvious to conclude in favour of a concept considering older adults education as an own approach, distinguished from education for younger adults (ibid.). The heterogeneity of the public is another aspect to reason a specific approach: Glendenning warns to see older adults as a homogeneous group (ibid.: 11). Lemieux and Martinez point also plurality of learners (ibid., 2000: 476) and concretise the idea by establishing two main categories: older adults with and without deficits.

Full continuing education is the only concept which does not argue in favour of a specific educational approach for older learners. Here, the older public is integrated in education as learners with particularities, like one can find them with all learners. The only chronological age is not a variable to define the public of education. Furthermore, all concepts identify and reasons learning aims. By this, the focus is not set on the question if older adults can learn or not, but on the purpose of the learning activity (Glendenning, 1992). The formulation of objectives is an essential aspect of the concepts and it is logical that the authors reason them in detail (Peterson, 1976; Glendenning, 1992; Veelken, 1990; Lemieux \& Martinez, 2000; Carré, 1980b). However, the analyse shows that the objectives are rarely based on stringently results of empirical or theoretical scientific research (Kern, 2011: 46). So one can think that these are rather propaedeutic reflections than systematic founded orientations.

Another common point is the type of learning offers. Even if the institutional or organisational framework is not always developed in detail, one can guess that learning activities are generally situated in formal settings. Informal learning contexts are not taken into account, so that particularities of this learn type are not integrated in the approaches. Considering that this form of learning is probably more important than formal learning (Strobel et al., 2011), one can ask the question about the role of non-participant of formal learning offers in the existing concepts.

\section{Main Difference: Argumentation of Epistemological Anchorage}

The most visible difference emanates from the denomination of the approaches and the related contexts of meaning. A detailed analysis is not possible here. For this we refer to other publications where notably the Greek roots of terms like geragogy, gerontagogy, gerogogy are developed (Ferro, 1997; Lemieux \& Martinez, 2000; Kern, 2007). To resume, one can note that the different meanings related to the Greek roots are not systematically used to reason the specificities of the approaches. Therefore, the chosen names seem neither to have a conceptual signification nor to establish a logical link to the epistemological base as we will see later.

Unfortunately, things do not become clearer by referring to Mieskes argumentation. When he proposed in 1970 the term 'geragogy' he made clear that Bollnow's proposition 'Gerontagogik' is the very right construction, in particular as regards grammar (Mieskes, 1970: 94). He precise not to want to provoke any quarrel between these terms: For Mieskes, both terms "sound anyway strange in the normal pedagogic ear yet" and he proposes that future decide about the 
pertinent term ${ }^{7}$ (ibid.: 95). Since then, four decades have passed and still no decision has been taken. Even worse, the question of terms is very rarely discussed in the research community. It is true that some of the terms are used by small, cultural related specialised communities to describe activities of trainers, educators or coaches working with older adults with - more or less explicit - learning objectives. But none of the terms, including Educational Gerontology, is used to describe an internationally large recognized scientific educational discipline.

\section{Two Different Epistemological Foundations: Gerontology and Education Sciences}

The Greek rooted terms do not permit to identify epistemological differences. In fact, authors use the same name for different concepts. This is also right as regards disciplinary anchoring. Geragogy, for example, is characterised as belonging to the educational discipline by Mieskes (1970), as linked to several disciplines by Petzold (1985) and as related to geriatrics by Lemieux (2001). Anyway, by analysing the different approaches, frequently the two disciplines 'educational sciences' and 'gerontology' on whin further development will concentrate appears.

The following reflection has necessarily a hypothetical character. Cultural differences between languages and academic disciplines are important, so that one must keep a safety distance towards assertions. The choice to base an approach on education sciences, on gerontology or on both, is not trivial but engages the choice it in the respective epistemological and scientific tradition as well as in the related methodological framework. In general, one can wonder if a multiple anchoring in education sciences and gerontology does not make it impossible to be identified and accepted by these targeted disciplines. If this is right, it would be difficult to earn recognition as a speciality within the disciplines. So, for simplifying, we focus our reflection on the approaches which are based either in educational sciences or in gerontology.

The particularity of gerontological or educational anchoring lies in the starting premises. The first starts reflection with "older public" while the second begins to think from "education". For education sciences, the chronological age is only one of the variables influencing education - and like Carré showed, it is, by far, not the most important. For the gerontological approaches like for example educational gerontology from Peterson (1976) or geragogy from Veelken (1990), the starting point of argumentation is not education but the (heterogeneous) group of older adults. Education is questioned from the public side and not from general considerations of educational order. Lemieux and Martinez (2000) made this observation already in their analysis of educational gerontology. On the other hand, gerogogy (Glendenning, 1992; Formosa, 2002), gerontagogy (Bollnow, 1962; Lemieux \& Martinez, 2000), full continuing education (Carré, 1980, 1985) as well as geragogy (Mieskes, 1970) are starting reflexion from the educational question ant not from the age. Essential theoretical references emanating here from authors which didn't necessarily work explicitly on older adults, but who are working about educational questions in general. 
To summarise, one can say that the models anchoring in gerontology are working on older adults in learning situations, while educational sciences founded approaches are dealing with learning situations which include (also) older adults. The chronological age is here - even if significant - only one variable of distinction beside others (physical health, initial education level, etc.).

\section{INSTEAD OF A CONCLUSION: PROPOSAL OF TRHEE EPISTEMOLOGICAL ELEMENTS ESSENTIAL FOR REFLEXION IN CONNECTION WITH TEACHING OLDER ADULTS}

Regarding multiple and various activities of learning of older adults ${ }^{8}$ one can see that the topic is important and concerns an increasing number of persons. Reflexion about epistemological anchoring is necessary in order to develop high-quality educational and training offers. That means offers which are adapted to the needs of learners. In this sense, the chapter proposes three central questionings. The aim is to suggest to planners and developers to focus on the following three aspects of learning offers for older adults. For the research on older adult education, they mark fields that require further investigation. The aspects are not structured hierarchically but are interdependent.

\section{Who is the Public?}

Adapted educational offers need to take into account the characteristics of the public. That means: to conceptualise appropriate training, it is necessary to know the audience. It is interesting to note that the different approaches remain very general for identifying the public (Kern, 2011). Most of them are referring to chronological age. Only the gerontagogy-geragogy model adds the variable medical health to distinguish learners. Though, the question is not only 'who' but also how the target public is identified. Regarding the very heterogeneous character of the target public, the question of the criteria for identifying the target public turns out to be central.

The extensive public definition of 'older adults' left a very large range of imaginable subcategories. Chronological age, we saw it before, is a simple but not necessary pertinent variable. Physical mobility is probably an implicit and inevitable criteria for vocational training offers: if the person is not autonomous in his movement, participation depends on support of a third person. Competences and skills can also be an essential criteria like educational level or socioeconomical status. It is clear that the number of criteria is not limited. However, the definition of the selection criteria of the public must be sufficiently detailed and appropriate to be able to accurately identify it. A clear and accurate definition can be seen as a condition of methodological quality. 


\section{What Do Older Adults Learn?}

The central concept here is the question of the learning needs of the learner (Kern, 2011, 2013). Learning needs are logically related to the definition of the public. It can even be a variable to define the public. But, it is at the same time an essential and independent aspect of epistemological reflection. A central issue of this thematic is the method to specify learning needs. Two main categories exist for this: the theoretical and the empirical ones.

One can presume that education and training are not perceived by the entire potential public as a value in itself. For some of them, learning activities are seen as a way to acquire skills and knowledge. One can suppose then that these older adults will not participate in education or training without a more or less defined objective which is related to their learning needs. So it is not unreasonable to question the potential audience about its learning needs. At the same time, participants don't need necessarily be aware of the knowledge or skills they can acquire. In fact, by participating to a learning activity, the learner may acquire skills, competences or knowledge that he ignored before but that can be useful for him. So, a theoretical construction of the learning needs may also be useful.

The direct questioning of the potential public permits to identify the conscious learning needs. But, to go further, beyond the current horizon of the learner, a theoretical construction of learning needs is necessary. Of course, this reflexion integrates ethical aspects. A special attention must be put on to the methodological argumentation of the instruments that permits to define learning needs. But this introduces already the following aspect.

\section{How Do They Learn?}

It has already been mentioned that these three elements are not hierarchically organised. But they are interrelated and interdepending. It is about a triangle where each peak is causally related to the other two. The learning situation is defined according to the answer at the question as how the public construct skills. That will say, how the target public learns? Focus is put on the learning process and learning situations (Kern, 2011). This huge field includes not only the institutional and organisational framework but also the methods, instruments and didactic arrangements. The learning situation is defined in relation to the public (variables) and to the identified learning needs. The construction of the methodological and didactic framework is necessarily based on the thorough knowledge of the public. The existing models of older adult education refer to formal learning situations like courses, workshops or conferences and propose a rich reflection base. Although, research results suggest that older adults learn more in non-formal and informal situations than in trainings and courses. An important domain in the future will be probably the self-directed learning. Hereby one can suppose that older adults who have the necessary skills will be autonomous learners. But what about the possible participants who does not know how to enter 
learning processes nor how to manage them? This leads the reflection to a crosscutting aspect concerning the non-participants in older adult education offers.

\section{What's about the Non-Participants in Older Adult Education Offers?}

We cannot proceed here to a conceptualisation of the notion 'non-participants'. This will be a future work. For the moment, we just note that it is about older adults who are normally concerned by learning offers but who do not use them. These adults also don't have the necessary skills for self-directed learning, or they do not use them. This kind of people is an interesting but difficult topic for all education researchers. Simple answers do not exist. First, the aim is not to find a solution, but to develop a reflection about this problematic. Possible orientations can be the study about factors which facilitate commitment in learning process and the one that make it difficult. Barriers as causal reason for non-participation may be found probably in all imaginable domains like organisational, methodological, conceptual, personal, etc. From an educational point of view the challenge is to develop methods sustaining older adults to overcome these barriers.

These three question fields as well as the non-participants topic are a proposal for discourse community to focusing epistemological reflexion on older adult education. It is about an invitation for colleagues to a critical debate with the aim to identify essential aspects for the research on learning of older adults. For this, we based our analyse on the main concepts in older adult education. The chapter gives an idea of the plurality of approaches. This diversity corresponds to the reality of older adult education in its world wide dimension as well as to the very heterogeneous character of the public.

This chapter ends with a quote of Bollnow (1962: 396) who suggested already in 1962 that gerontagogy has to contribute in a constructive way to education work: "it seems urgent to me, that this problem will be approached from the scientific point of view in a systematic way". ${ }^{9}$ Half a century later, one can note that the work started and that a rich scientific corpus exists, but also that some important questions keep on challenging researchers.

NOTES

Gerontagogy and geragogy.

Original text: "Lehre von der Erziehung der alten Menschen" (translation by D. Kern).

Original text: "Es genügt nämlich nicht, den Menschen durch ärztliche Hilfe ihre Altersbeschwerden zu erleichtern und sie durch gelegentliche Unterhaltung von ihnen abzulenken; es kommt vielmehr darauf an, ihnen zu helfen, mit ihrem Alter in einer richtigen und sinnvollen Weise fertig zu werden. Das ist eine erzieherische Aufgabe" (translation by D. Kern).

4 Original text: "Pädagogik des Alters und des alten Menschen" (translation by D. Kern). 
5 Original text: "Gegenständlich bezeichnet Geragogik die Summe aller wissenschaftlichen Aussagen, deren Gehalt auf die pädagogische Wirklichkeit des alternden und alten Menschen bezogen ist" (translation by D. Kern).

6 Original text: "éducation permanente intégrale" (translation by D. Kern).

7 Original text: "Der eine wie der andere Begriff ist dem pädagogischen Normalohr ohnehin noch befremdlich. Mag deshalb die Zeit entscheiden" (translation by D. Kern).

8 This aspect has not been developed in this work but different publications of the author (like the one cited) permits a overview. In addition, a simply Internet research gives an idea of world wide offers.

9 Original text: "Es scheint mir dringend, daß dieses Problem auch von der wissenschaftlichen Seite her einmal systematisch in Angriff genommen wird" (translation by D. Kern).

\section{REFERENCES}

Bollnow, O. F. (1962). Das hohe Alter. In Neue Sammlung. Accessed 15/9/14 from: http://www.ottofriedrich-bollnow.de/doc/HohesAlter.pdf

Bollnow, O. F. (1966). Krise und neuer Anfang. Heidelberg: Quelle \& Meyer.

Carré, P. (1980a). Gérontologie educative et psychopédagogie: Spécificité des situations de formation à l'age de la retraite et unité de l'éducation permanente. Gérontologie et Société, 13, 29-39.

Carré, P. (1980b). Le troisième âge de l'éducation permanente. Éducation permanente, 56, 43-69.

Carré, P. (1981). Gérontagogie ou éducation permanente intégrale? Éducation permanente, 61, 107-125.

Carré, P. (1985). Education des adultes et gerontology: Origine d'une rencontre. Gérontologie et société 33, 39- 44.

Donahue, W. (1955). Education for later maturity a handbook. New York: Whiteside and Morrow.

Donahue, W. (1960). A group-study approach: Grand Rapids learns about the aging. In R.H. Williams, C. Tibbitts, \& W. Donahue (Eds.), Aging in today's society (pp. 377-382). Englewood Cliffs, NJ: Prentice-Hall.

Ferro, T. (1997). The linguistics of Andragogy and its offspring. Paper presented at the Midwest Research-to-Practice Conference in Adult, Continuing, and Community Education, Michigan State University, USA. Accessed 15/9/14 from: http://www.umsl.edu/ henschkej/henschke/more\%20 henschke_5_11_04/the_linguistics_of_andragogy_and_its_offspring.pdf

Formosa, M. (2002). Critical gerogogy: developing practical possibilities for critical educational gerontology. Education and Ageing, 17(1), 73-85.

Formosa, M. (2011). Critical educational gerontology: A third statement of first principles. International Journal of Education and Ageing, 2(1), 7-22.

Glendenning, F. (1989). Educational gerontology in Britain as an emerging field of study and practice. Educational Gerontology, 15(2), 121-131.

Glendenning, F. (1992). Educational gerontology and gerogogy: A critical perspective. Gerontology \& Geriatrics Education, 13(1/2), 5-22.

Kern, D. (2007). La prévention de l'isolement à travers la formation tout au long de la vie spécifique aux personnes âgées - étude sur les besoins de formation des personnes en transition entre l'âge de la retraite et le grand âge. $\mathrm{PhD}$ in Educational Sciences, 26 June 2007, University of Haute Alsace, in Mulhouse. Accessed 15/9/14 from: http://www.scd.uha.fr/flora/jsp/index_view_direct anonymous.jsp?record=defaultfortmelectro:TM_ELECTRO:11

Kern, D. (2011). Vieillissement et formation des adultes - Note de synthèse. Revue Savoirs, 26, 13-59.

Kern, D. (2013). Les besoins d'apprentissage spécifiques au grand âge. Gérontologie et Société, 147, 107-119. 
Lemieux, A. (2001). La gérontagogie: une nouvelle réalité. Montréal: Editions nouvelles.

Lemieux, A., \& Martinez, M. S. (2000). Gerontagogy beyond word: a reality. Educational Gerontology, $26(5), 475-498$.

Mieskes, H. (1970). Geragogik - Pädagogik des Alters und des alten Menschen. Pädagogische Rundschau, 24, 89-101.

Peterson, D. A. (1976). Educational gerontology: the state of the art. Educational Gerontology, 1(1), 6173.

Peterson, D. A. (1980). Who are the educational gerontologists? Educational Gerontology, 5(1), 65-77.

Petzold, H. (1985). Vorwort. In H. Petzold (Ed.), Mit alten menschen arbeiten - Bildungsarbeit, psychotherapie, soziotherapie (pp. 7-10). München: Pfeiffer.

Petzold, H. (Ed.). (1985). Mit alten Menschen arbeiten - Bildungsarbeit, Psychotherapie, Soziotherapie. München: Pfeiffer.

Strobel, C., Schmidt-Hertha, B., \& Gnahs, D. (2011). Bildungsbiographische und soziale Bedingungen des Lernens in der Nacherwerbsphase. Magazin Erwachsenenbildung.at, 13, 1-12. Accessed 15/9/14 from: http://erwachsenenbildung.at/magazin/11-13/meb11-13.pdf

Veelken, L. (1990). Neues lernen im alter - Bildungs-und kulturarbeit mit "jungen alten". Heidelberg: Sauer.

Dominique Kern

Faculty of Arts, Languages and Humanities

University of Haute Alsace

France 


\title{
ALFREDO ALFAGEME
}

\section{TEMPORARY EXIT FROM EMPLOYMENT}

\author{
Possibilities for Lifelong Learning in Early Retirement
}

\section{INTRODUCTION}

The proposal for paid temporary exit from employment (TEFE) sets out to combine a series of well-grounded academic bases with criteria of interest to society, while at the same time maintaining the resolve to improve equality of opportunity in our societies. The idea of temporary exit from paid employment is not a new one. Riley (1979), for example, proposed setting aside differentiated agebased periods for education, work and leisure to make way for opportunities for all three aspects throughout the whole life course.

In this line, one of the current challenges in the European Union is the distribution of work, in a broad sense (paid work, education and training, domestic work), throughout life, as a way of promoting equal opportunities between women and men. Thus, for example, reports such as the one by Naegele and colleagues (2003) discuss measures like 'working time accounts' (periods of work without pay that are exchanged for periods of leave when necessary) or "leave options" (relatively long periods of leave from paid work to engage in tasks for which other measures or support are insufficient). Scholars such as Vaupel and Loichinger (2006) take into account the demographic trends of our societies, emphasising the need to redistribute work throughout the life course especially at later stages, based above all on the expansion of part-time work through every stage of life.

Our own efforts in this field focus on the proposal for a new and more egalitarian legal framework - with particular emphasis on creating opportunities for the working class - that would draw on the resources allocated for retirement pensions. This proposal has been presented elsewhere (Alfageme et al., 2012), and the Sociology of Ageing research group at the Universitat Jaume I of Castelló (Spain) continues to explore this subject, both in terms of its economic feasibility and its potential as a policy of equality. In this chapter, we will specifically analyse the potential of TEFE as a policy to encourage lifelong education and training and, therefore, highly suitable for overcoming educational inequalities among adults, facilitating access to education and training for people working in paid jobs who cannot, or do not want to, give up a steady income. Formal adult education would thus become a real accessible right for everyone, regardless of their economic status. Lifelong education should become a reality (Guillemard, 2013) and this proposal may offer one way of achieving it.

The importance of formal education in overcoming social inequalities is widely recognised. Inclusive education during the early stages of life is particularly 
critical, and renowned research groups on education are working at an international level on this question, supported by European funding (Soler, 2011; Flecha, 2012) (see the website of the INCLUD-ED project, Strategies for inclusion and social cohesion in Europe from Education: http://creaub.info/included/). However, education authorities do not always take up the recommendations of quality scientific research, or they do not have the resources to put into practice the most suitable actions. This is one of the reasons for the persistence of educational inequalities, which in all likelihood could be redressed in later life, particularly in adulthood, if the legal framework and other resources were adapted for the purpose. The proposal we discuss takes this line.

Moreover, regardless of the social inequalities caused by unequal educational opportunities in early life, there is now a clear consensus about the need for lifelong learning, also during later life, as part of the so-called 'information society'. However, despite this broad recognition, there seems to be no such clear agreement over the way or ways these needs should be addressed, perhaps due to a number of reasons that well illustrate the complexity of the issue. In all probability, these reasons are closely related to the historical inertia of the institutionalised three-stage life course (learning, work and retirement). There are at least two large sets of activities that need to be undertaken throughout life, to varying degrees, and that are conditioned by a wide range of circumstances. The first is care work and the second, training and education. Caring, which covers all types of domestic tasks, has traditionally been done by women in the context of a sexual division of labour, tailored exclusively for men, within which the three-stage life course made sense. Current thought, however, highlights the androcentric nature of this arrangement and the need for new alternatives (García Pastor \& Viñado, 2013). With regard to education and training, this relatively inflexible life course model made more sense in what were fairly changeless, less egalitarian societies. The information society demands greater flexibility in this regard, without accentuating the inequalities deriving from unequal opportunities of access to educational resources throughout adult lives, as is often the case.

However, these traditional structures appear to be firmly entrenched, from schooling in the early stages of life to retirement in the final stage. Perhaps for this reason partial reforms often fail to give satisfactory results, or perhaps simply the time has come to assess and implement more wide reaching structural reforms. In our view, a general approach to the processes of education and training, work and retirement throughout life is needed, covering the whole set of tasks (education and training, paid work and domestic work) that have to be done throughout the life cycle, and considering in turn equal opportunities in all these areas. This argument also underlies the TEFE proposal we defend and will develop further in the following sections.

\section{THE LIFE COURSE PERSPECTIVE AND THE POSSIBILITY OF TEMPORARY EXIT}

We adopt the life course perspective, a relatively recent approach that pays special attention to historical context and personal trajectories, considering, for example, 
diversity and social inequalities among individuals and groups, and the decisive influence of historical regimes and differences between societies whose institutions and mechanisms shape the life course (Dannefer, 2003; Ulrich, 2004). It aims to recognise, for example, the centrality of work and the role of institutions in defining an age-based life course, leading to the three-way division of life stages (learning, work and retirement) with which we are so familiar (Henretta, 2003; Settersten, 2006; Guillemard, 2009).

We must keep in mind that this three-stage institutionalisation of the life course took place under very different historical reference points from those of today. It came out of a clear sexual division of labour, which is now being pushed aside by the irreversible decline of patriarchal domination that some authors have identified as the most significant revolution of our time (Castells, 1996: 160; Solé, 1998: 257-261). Secondly, this life course model, which included retirement as the final stage, was attuned to much younger societies that bear no resemblance to the current reality: life expectancy in Europe has increased exponentially (and continues to do so), while disability-free life expectancy for 65-year-olds is between eight and ten years approximately. This phenomenon should not become a serious problem as long as adequate social and economic policy measures are taken (Schoenmaeckers \& Kotowska, 2005). Thirdly, the wide recognition of the needs of lifelong learning is closely related to the characteristics of the so-called 'information society', brought about by the advances in information and communication technologies and that calls for greater democratisation of knowledge. Lifelong learning needs are increasingly evident, both to extend active working life (Phillipson, 2013) and for other reasons related to personal development, especially in advanced years (Formosa, 2013).

However, there is a distinct absence of truly transformative proposals from either academic or political spheres. This lack of attention may well be linked to the cultural entrenchment of both the institutionalisation of the three-stage life course and the sexual division of labour. Burke and colleagues (2013) ask why there has been no early response to the process of ageing populations. They argue, firstly, that the time span needed to plan such a response is much longer than the limited periods the political and economic powers focus on their main interests, which are more concerned with short-term profit. And secondly, a holistic response to these changes requires a multidisciplinary, complex approach that is not easily coordinated and brought into effect.

\section{EDUCATIONAL INEQUALITIES RELATED TO THE THREE-STAGE LIFE COURSE}

Compulsory schooling for children and adolescents is deeply rooted in western culture. Few parents consider the alternatives to enrolling their children in school. The idea that this stage of formal schooling ends with adolescence or early adulthood is also firmly entrenched, and in the normal course of events, children will never again go through a similar experience in their lifetimes. The level of education attained during the first stage of life is, in most cases, conclusive, with all that this implies in terms of opportunities for personal and social development, 
and especially perhaps in the work environment. Analyses of this reality tend to be either functionalist or critical, based on now classic proposals such as theories of human capital or of reproduction, respectively.

Whatever the case, compulsory schooling in the early stages of life results in social division, either because of individual abilities and desires (functionalist approach) or social background (theories of reproduction and the like). As so often is the case, each perspective provides partial insight into aspects of a complex multidimensional reality that cannot be adequately covered by simplistic approaches. Both approaches, however, are to some extent stagnated, as they do not consider the transformative and critical potential of schools and teachers in today's information society. As mentioned above, acclaimed European research teams are working on this question.

From a critical perspective of the life course, which interests us here, the social divisions that the school process variously leads to are especially important because they are definitive, largely because schooling is only accessible - in practice and for the vast majority of people - in the early stages of life. The system does not subsidise or promote adult access to programmes of formal education in any other way, which results in clearly marked relative disadvantages for the working classes with fewer resources; they are thus confined, from their youth and for the rest of their lives, to ignorance of academic or systematic knowledge and to more poorly paid low skilled jobs.

In 2001, the European Commission published a communication entitled Making a European Area of Lifelong Learning a Reality. Its definition of the concept of lifelong learning was based on the one established within the context of the European Employment Strategy, but the consultation stage revealed an apparently widespread concern about the over-dominance of the employment and labour market dimensions. A set of targets were therefore agreed around issues of personal fulfilment and social integration, as well as employability and adaptability, and the following definition of lifelong learning was proposed:

all learning activity undertaken throughout life, with the aim of improving knowledge, skills and competences within a personal, civic, social and/or employment-related perspective. (Commission of the European Communities, 2001)

If social inequalities are ignored, the critical considerations implied are patent. Individuals and families who most need income from paid work are those who, in practice, have fewer opportunities for formal learning throughout their lives (unless they are able to, in line with the TEFE proposed here, enjoy sufficiently long periods of paid temporary exit).

\section{THE CENTRAL ROLE OF UNIVERSITIES}

University students are, in general, young people men and women who begin their studies at the age of 18 to 20 , that is, immediately after finishing their earlier formal studies, which then require further enhancement. The university is therefore 
and above all, a place that accommodates young people who continue their studies. This may seem logical, because it is what most commonly happens, but it is not clear whether it is the most desirable, the fairest, or the most suitable model for today's society. Universities could be a place for everyone who has a clear interest to learn in a more or less specified way, as a result of reflection and their own decisions and, consequently, with guaranteed motivation, if they had a reasonable chance of doing so. The question is: Does this happen precisely at the age of 18 to 20 or because they have finished their earlier formal studies? This may occur in some or even many cases, but the general answer is probably no. Rather, a responsible, deliberated decision to go to university will emerge from mature reflection which can happen in any stage of adulthood. Perhaps, therefore, a more advanced society and university system would have a more varied clientele, consisting of young people, adults and seniors, which would also be in line with a relatively ageing demographic structure. Against this, however, is the social construction of life stages, deeply rooted in our culture, and one of the tangible results of which is that the vast majority of people who study do so during their youth, first at school and then at university.

Apparently, a notable exception to this trend is seen in the University Programmes for Older Adults (UPOA), which have expanded dramatically in Europe over the last two decades. However, this exception is only apparent, since these programmes are clearly different from other university courses. No conditions of enrolment are required, nor do they lead to professional qualifications, as they are not oriented towards employment, but towards other objectives of social integration or personal development. Universities are therefore attended either by young people who go to train for employment, or older people who go because they no longer work nor wish to do so. To paraphrase the title of the abovementioned European Commission communication, much of the 'European area of lifelong learning' remains empty because there are no adults (with the exception of the very young and the very old) between the ages of 25 and 55, approximately. Today's universities, moreover, may be multi-generational, with many young people and considerable numbers of seniors, but they are not intergenerational, because neither the universities themselves nor the broader social structure encourage intergenerational relationships sufficiently.

Additionally, not all educational programmes for adults fulfil a truly emancipatory function; programmes frequently reproduce rather than prevent social inequalities, and certain interests, perhaps control, may underlie these programmes, interests that have little or nothing to do with the interests of adults and seniors (Formosa, 2009; Glendenning, 2000; Cusak, 1999). Most UPOA are unregulated programmes, generally aimed at people over 50 or 55 years. Clearly these programmes do not address the learning continuity of those who enrol in them, but rather they are a response to the end of paid work. These new university programmes for older adults risk becoming yet another consumer item, with similar unwanted effects to those of other entertainment activities aimed at older people, and also contributing to the reproduction of social inequalities. 
Among the issues a necessarily critical analysis of UPOA should consider is the possibility that, at least in part, the attraction of such programmes lies precisely in their selective nature, although this may not be explicitly recognised by any of the parties involved (Alfageme, 2007). In other words, the people who enrol in such programmes are seeking not so much education, but contact with a group of socially like-minded people to interact and establish relationships with. This motivation is less difficult to recognise, as it falls in line with the social function of UPOA. If this is the case, what is called into question is the fact that public universities are the ones organising and sustaining such programmes. For these purposes, other models would be more appropriate, such as those typically found in the United Kingdom, based on the initiatives of and organised by adult and older people themselves.

Linked more directly to our interests, the functions fulfilled by UPOA revive old debates about compensation for social exclusion processes through affirmative action policies. Thus, retirement policies on grounds of age can be seen to exclude people above a certain age from the paid work on which society places a high value. For its part, the UPOA criterion of exclusive or preferential admission for people above a certain age (55, for example) may be regarded as an affirmative action policy to promote their social integration, since they are excluded from other areas of social life. In fact, the great majority of the people attending these educational programmes are retirees, even those between 55 and 65 years (prior to the official retirement age). The coincidence between retirement and attending UPOA is clear, also in the case of women, since those who have worked in paid jobs and who have retired (a minority in many European societies are clearly overrepresented in these programmes. As noted above, this is not so much lifelong learning as learning in the last third of life, although this function is not met fully either, since few very old people enrol in them (Alfageme, 2007). As Formosa (2013) explains, these programmes meet the needs of the 'third age', but not of the 'fourth age'.

However, what I now want to point out is that even if we understand UPOA or similar programmes as an affirmative action policy, they are still policies with a very limited scope, a stopgap, against the much broader and more widespread social exclusion mechanism of retirement. Here, we return to the general critique of the institution of retirement put forward since the 80 s by theorists of seniors' structured dependency (Walker, 1980; Townsend, 1981) and the political economy of ageing (Minkler \& Estes, 1984). There is a notable consensus that UPOA are helping many seniors to reengage in social activities, some of which are very similar to the activities they are distanced from after retirement (relationships with other people, some physical activity, informal learning, etc.). These seem to be the reasons why, as their teachers frequently note, on completing a course or programme many of these students wish to continue, and do not find it easy to leave university.

Without proposing alternatives to retirement, any attempt at social integration of older people (in education, for example) seems doomed, at best, to have a very limited scope, just as any attempt to overcome inequalities between men and 
women in the workplace is doomed if the institutionalised three-stage life course (learning, work and retirement) is not questioned. And if programmes for seniors uncritically accept the institution of retirement on grounds of age as healthy and/or unavoidable, then this response can be stated more forcefully, since it is evident that such programmes do not take into account the diversity of needs, capacities and preferences of the people they are intended for (adults and seniors). They do not consider, for example, that older people might want to train for work. In this vein, the idea can be defended that numerous programmes (including UPOA) operate as satellites of forced retirement and contribute to the social construction of old age or "being old". However, non-formal type programmes (such as the UK model referred to above) seem more appropriate for such actions. These have a strong local base and are not necessarily organised by educational institutions, although they may use their premises. Such programmes are more likely to respond to the educational needs of local people, and are less selective and more participatory than formal programmes.

Therefore, it follows from the above argument that if there is the political will to introduce learning programmes throughout adult life that are egalitarian (in the sense that all people have reasonable opportunities to access them), it is simply necessary for people to have paid temporary exit options for this type of activity. Otherwise, even if the programmes were formally open to all ages, they would continue to be taken up by mostly older (retired) people.

Universities, one of the institutions that most clearly have a leading role in learning throughout adult lives, enjoy sufficient autonomy to open up their programmes to people of all ages. Some models have now become relatively established, for example, university access for over 25-year-olds in Spain. Other models are more recent, such as considering work experience as an alternative to access requirements for people over 40 or 45 years. But what can be done by universities or other educational institutions is insufficient. The alternatives to early retirement and the chance to distribute paid periods of exit throughout life are issues that imply a much broader transformation of our societies, taking a clearly egalitarian direction.

\section{TEMPORARY EXIT FROM EMPLOYMENT (TEFE): A NEW MORE EGALITARIAN LEGAL FRAMEWORK}

We therefore argue that there is a need to address the issue of lifelong learning within the broader set of activities that people do throughout their lives, such as caring, or leisure activities. These activities are just as necessary and worthy of value as paid work. Considering them as a whole is the best way to justify the need to distribute periods of paid exit from employment throughout life, taking into account people's needs and wishes, instead of concentrating retirement in the third and final stage of life.

Because the TEFE proposal is truly transformative, it may seem utopian or unfeasible. However, in our view it is socially desirable and economically viable, since there are numerous ways in which it might be regulated (Alfageme, 2009). 
The proposal is designed for today's young people and adults, whose disabilityfree life expectancy is around 75 and who might benefit from, for example, up to eight or ten years of paid temporary exit from work, depending on their wants and needs, with their final retirement age being postponed proportionally.

If individuals had these socially recognised and promoted opportunities to arrange their life course differently from the conventional way, they would be likely to take advantage of them on various occasions. This is a pertinent question for social research. Consider, for example, parents who want to devote more time to their young children, or people who opt to care for others - their older relatives for instance - for reasons of dependence. Or those who choose to take time out of paid employment to pursue other unpaid activities, including, of course, education and training. All of the above would be part of a healthy process that would also help to alleviate the monotony and burnout experienced by so many workers, and would frequently result in greater levels of personal satisfaction and performance at work (recall that some professions already enjoy the right to relatively long periods of exit from work, or sabbatical leave). The right to temporary exit from employment throughout life would empower working class men and women, giving them greater autonomy and bargaining power in such a relevant aspect as the distribution of their working time (inside or outside the home), education and training, time for relaxation, and so forth, throughout their lives.

If there was a real possibility for TEFE throughout life, educational institutions would be expected to adapt their offer to the new situation. Intergenerational relations in schools could become a reality. The possibility of breaking with the dismal image of workers in the workplace and in the domestic or other spheres, disappointed by not having had the training opportunities they would have liked or would like now, seems to be a very healthy and interesting way forward. For the less favoured groups in society, awareness of the importance of schooling comes late, which could be offset - in part at least - if they had the resources (time and money) for formal learning in adulthood. These issues are extremely relevant to equal opportunities for all people and sectors of society.

In the case of universities, initiatives such as university programmes for seniors, referred to above, could actually open up to all ages. In turn, more flexible regulation of both access to and the workings of formal university studies would make much more sense and would be truly effective, ensuring that they are indeed open to people of any age and social background.

\section{REFERENCES}

Alfageme, A. (2007). The clients and functions of Spanish university programmes for older people: A sociological analysis. Ageing \& Society, 27(3), 343-361.

Alfageme, A. (2009). El retiro temporal a lo largo del curso vital: Contexto, regulación y consecuencias. Recerca, 9, 41-58.

Alfageme, A. García Pastor, B., \& Viñado, C. (2012). Temporary exit from employment throughout the life course: An alternative to retirement to challenge ageism and sexism. Critical Social Policy, 32(4), 696-708. 
Burke, R. J., Cooper, C., \& Field, J. (2013). The aging workforce: Individual, organizational and societal opportunities and challenges. In J. Field, R. J. Burke, \& C. L. Cooper (Eds.), Aging, work and society (pp. 1-20). London: Sage.

Castells, M. (1996). La era de la información. Madrid: Alianza.

Commission of the European Communities. (2001). Making a European area of lifelong learning $a$ reality. Brussels: COM (2001) 678 final.

Cusak, S. (1999). Critical educational gerontology and the imperative to empower. Education and Ageing, 14(1), 21-37.

Dannefer, D. (2003). Cumulative advantage/disadvantage and the life course: Cross-fertilizing age and social science theory. Journal of Gerontology: Social Sciences, 58B(6), S327-S337.

Field, J., Burke, R. J., \& Cooper, C. L. (Eds.). (2013). Aging, work and society. London: Sage.

Flecha, R. (2012). European research, social innovations and successful cooperativist. International Journal of Quality and Service Sciences, 4(4), 332-344.

Formosa, M. (2009). Renewing Universities of the Third Age: Challenges and visions for the future. Recerca, 9, 171-196.

Formosa, M. (2013). Policies for older adults learning: The case of the European Union. In J. Field, R. J. Burke, \& C. L. Cooper (Eds.), Aging, work and society (pp. 461-476). London: Sage.

García Pastor, B., \& Viñado, C. (2013). Análisis crítico del curso vital institucionalizado: Conciliación y retiro temporal del trabajo remunerado. Research on Ageing and Social Policy, 1(1), 78-97.

Glendenning, F. (2000). Teaching and learning in later life: Theoretical implications. Aldershot: Ashgate Publishing.

Guillemard, A. M. (2009). Un curso vital más flexible: Nuevos riesgos y desafíos para la protección social. Recerca, 9, 13-39.

Guillemard, A. M. (2013). Prolonging working life in an aging world: A cross-national perspective on labor market and welfare policies toward active aging. In J. Field, R. J. Burke, \& C. L. Cooper (Eds.), Aging, work and society (pp. 60-74). London: Sage.

Henretta, J. C. (2003). The life-course perspective on work and retirement. In R. A. Settersen (Ed.), Invitation to the life course: Toward new understandings of later life (pp. 85-105) New York: Baywood Publishing Company.

Minkler, M., \& Estes, C. (1984). Readings in the political economy of aging. New York: Baywood Publ. Comp.

Naegele, G., Barkholdt, C., de Vroom, B., Goul Andersen, J., \& Krämer, K. (2003). A new organisation of time over working life. Dublin: European Foundation for the Improvement of Living and Working Conditions (European Union).

Phillipson, C. (2013). Reconstructing work and retirement: Labour market trends and policy issues. In J. Field, R. J. Burke, \& C. L. Cooper (Eds.), Aging, work and society (pp. 445-460). London: Sage.

Riley, M. W. (1979). Introduction: Life-course perspectives. In M. W. Riley (Ed.), Aging from birth to death (pp. 3-13). Boulder, CO: Westview Press.

Schoenmaeckers, R., \& Kotowska, I. (2005). Population ageing and its challenges to social policy. Strasbourg: Council of Europe Press.

Settersten, R. A. (2006). Age structuring and the rhythm of the life course. In J. T. Mortimer \& M. J. Shanahan (Eds.), Handbook of the life course (pp.79-98). New York: Springer.

Solé, C. (1998). Modernidad y modernización. Barcelona: Anthropos.

Soler, M. (2011). Editorial. European Journal of Education, 46(2), 169-172.

Townsend, P. (1981). The structured dependency of the elderly: A creation of social policy in the twentieth century. Ageing and Society, 1(1), 5-28.

Ulrich, K. (2004). Whose lives? How history, societies, and institutions define and shape life courses. Research in Human Development, 1(3), 161-87.

Vaupel, J. W., \& Loichinger, E. (2006). Redistributing work in aging Europe. Science, 312(5782), 1911-1913. 


\section{ALFAGEME}

Walker, A. (1980). The social creation of poverty and dependency in old age. Journal of Social Policy, 9(1), 49-75.

\section{Alfredo Alfageme}

Department of Philosophy and Sociology

Universitat Jaume I (Castelló, Spain)

Spain 


\title{
9. LIFELONG LEARNING AND SKILLS DEVELOPMENT IN THE CONTEXT OF INNOVATION PERFORMANCE
}

\author{
An International Comparison
}

\section{INTRODUCTION}

Thematically this article is located at the intersection of three broader topics: the changing demographics in the workplaces, particularly workforce ageing; jobrelated skills and competence, and; learning, creativity and innovation for individual and societal productivity and prosperity. The starting point here is the situation in which the proportion of ageing workers (40-plus) in workplaces is increasing. This trend is accelerating in many countries in the years to come (UN, 2013). This is happening at a time when "skills have become the global currency of 21 st century economies" (OECD, 2012a), the key to productivity and employment (ILO, 2008), and innovation activity is both accelerating and being sought for economic progress, prosperity and well-being (OECD, 2012b) - and when a modest economic recovery is forecast for Europe towards 2020 (EC, 2014a). The European Union's growth strategy Europe 2020 (EC, 2010) addresses these issues through at least two of its seven flagship initiatives, An Agenda for New Skills for New Jobs and Innovation Union.

While there is a solid body of research on the relationship of job-competence and innovation, research connecting the relationship explicitly to workforce ageing is very limited. However, some studies do exist. Examples are an analysis of the relationship between employee age (older workers) and attitudes and reaction to implementation of a new information technology initiative/innovation in a workplace, seeking to "promote innovative processes that may help organizations be more competitive in the modern marketplace" (Rizzuto, 2011: 1612), and Henseke and Tivige's (2007) research on innovation patents as a function of age of the innovators and sector.

From the research on the three themes separately, a rather ambiguous view emerges on ageing workers, and how their job-performance could be related to the call for higher skills and promotion of innovation ability and activity (Tikkanen, 2011a). Predominantly, though not only, we could expect older workers - with their 'lacking' and/or 'obsolete' skills - to report of stronger learning and development needs, but at the same time - with their 'less positive learning attitudes' and 'eroded learning skills' - lower interest in skills development than younger workers. The Science-Technology-Innovation (STI) approach (OECD, 
2010a), presents innovation as an activity carried out in higher education institutions, by young people, and inseparable from development of high technology and sciences. As Henseke and Tivig (2007) point out, if we are to believe that science and engineering are only for young people, the ageing society will pose a serious concern for innovation and creativity.

It is to these challenges that this article aims to contribute to with an empirical study, based on a new data from the Programme for the International Assessment of Adult Competencies (PIAAC) by the OECD (2013a). Two research questions will guide the study. Firstly, to what extent is there age-related variation in employees' job-related learning needs and skills development practices? Secondly, to what extent, if any, is the age-relationships with learning needs and skills development related to innovation performance in Europe? There is evidence from previous research (Cedefop, 2012a; Lundvall \& Lorenz, 2012) on a link between learning at workplaces and innovation on a national level. This study aims to provide new knowledge by examining this relationship further against workforce ageing in Europe.

The chapter is structured into four main parts. The first part illuminates existing research and theoretical approaches on the three overlapping themes, divided into three sections accordingly. Section one describes the greying of the workplaces in the light of statistics, section two the concept(s) and status of skills, competence, job performance of ageing workers. Job performance has been given more attention, due to its centrality in the context of innovation capability. The third section highlights skills development practices through lifelong learning participation in the context of older workers' employment and national innovation performance and creativity. The second part of the article presents the research methodology and the third research findings. The final part is discussion and describing conclusions with a suggestion for further research.

\section{WORKPLACES ARE GETTING GREY}

Population ageing is expected to pose a serious threat to macroeconomic performance and competitiveness in European countries (European Foundation, 2008), and the pace of this change is expected to accelerate in the coming years (UN, 2013). The age-group 60-plus years is increasing and already exceeds $25 \%$ of the population in Germany, Italy and Japan, which have the highest median ages in the world (already in 2010 more than 50\% of the population in Japan was over 45 years of age) (UN, 2013). European population median age is expected to rise to 49.3 years by 2060 from 40 years in 2010 (Statistical spotlight, 2013). Due to the demographic trends of ageing of the baby-boomers and simultaneous decline of young people under 30 years of age, from 2013/2014 onwards the European working age (15-64 year olds) population has started to shrink (EC, 2011). It is expected to fall by about 50 million, to $56 \%$ of the total population, while the population older than 65 will increase by more than 60 million, to $30 \%$ of the total population, within the next about 40 years by 2050. As baby-boomers will exit the workforce at about the same time, a critical labour shortage is 
expected, already by 2030 of some 20.8 million people of working age in the European Union. (European Foundation, 2008), most significantly in high-skill occupations (Cedefop, 2012b). The trend is global. According to the estimations by McKinsey (2012) by the year 2020 there will be a potential shortage of about 16-18 million high-skill workers in advanced economies (high in GDP per capita and high educational attainment) and of another 23 million college-educated workers in China alone.

Meanwhile, workplaces are getting grey. Historically, this is a completely new situation (OECD, 2006), calling in itself for new knowledge, creative thinking and innovative solutions (Tikkanen, 2011a). The demographic trends have been active for long, but the outcomes have really started to show in a larger scale only recently. In the future, the age group $60+$ years is expected to remain in working life still a good many years to help to balance the labor market imbalance (Cedefop, 2010a) - a point made explicit in the recent pension reforms in many European countries. Furthermore, for many older workers personal financial reasons (Brown, 2012; Sok, 2010) make it necessary to keep on working towards their late 60 s and even beyond.

Clearly, employers and management, as well as societies as whole, will face major new challenges - and opportunities - along with the demographic change (EC, 2007; OECD, 2006). Many countries are facing a situation where securing adequate labour force in the future requires either increasing the immigration of (young) skilled labour (Zaidi, 2008) or extending the job careers of senior workers - or both. There are examples of both kinds of development already taking place (Tikkanen \& Billett, 2014). There is also evidence, showing that companies' human resources policies have started to change as they work towards attracting and retaining high-skilled labour, especially in the areas of skills-indemand (Restrepo \& Shuford, 2012; Shapiro et al., 2011).

\section{WORKPLACE LEARNING FOR SKILLS AND COMPETENCE DEVELOPMENT}

\section{Skills and Competence}

The concept of skills has entered the economic and socio-political agenda the last years for fostering innovation (McKinsey, 2012; OECD, 2011, 2012b, 2013a). In the on-going competition for talents and "best heads", as well as the strong focus on skills and competence, the demographic development is a strong undercurrent. While there are generic skills or domain-independent knowledge, a relevant question in this context is to what extent is it possible or makes sense to make general arguments about older workers' skills and their sufficiency, given the variety of domain specific knowledge and job-related skills, as well as their wealth of experience-based knowledge. What do we mean by skills and competence?

The concepts competence and skills are often used interchangeably (OECD, 2013b). Yet, competence (in singular) is generally, and particularly in the Nordic countries, understood as a significantly larger concept comprising of knowledge, skills, and attitudes. Although widely and commonly used, an exhaustive, 
unanimous definition of the concept in this broad sense is difficult, regardless of the many efforts made (for an analysis, see OECD, 2013b: 93-98). Beside the challenges in its theoretical conceptualization, in an international context additional challenges are introduced by the cultural, lingual and socio-economic differences. Consequently, many meanings are attached to job-competence (Ellström, 1997; Ellström \& Koch, 2008). This fact makes it also difficult to measure jobcompetence in a reliable way. Consequently, an emphasis of the choice for the narrower concept of skills (or job-skills) by for example the European Commission (Cedefop, 2012b) and the OECD (2012a, 2013a, 2013b) in their recent work, is highly understandable.

In this paper we have used the two concepts side-by-side, yet the concept of jobcompetence in the broad sense described above. With skills we refer to narrower, specific elements in one's total competence. Thus, we follow the recent OECD's definition. Their current program on adult learning is titled the Programme for the International Assessment of Adult Competencies (PIAAC), but the empirical survey carried out as a part of it is titled Survey of Adult Skills (OECD, 2013b). In PIAAC the two concepts are used interchangeably (OECD, 2013b).

The prevailing theoretical perspectives on competence propose that it is the workplace where the most important, continuous learning and job-competence development - as well as competence stagnation - takes place (for an overview, see Malloch et al., 2011). In this view, the discussion of the competence and jobperformance of older workers - or workers of any age, for that matter - cannot be separated from the context of their jobs and work organizations. By time, a person's initial competence at the time of recruitment is shaped by his or her jobtasks, on the context of the job-tasks, workplace and organization. Thus, albeit often treated as an individual matter, especially in the case of older workers, jobcompetence at any point of time should be treated as a shared responsibility between the individual and his or her organization (employer/management). Thus, a definition of skills and job-competence is crucial when thinking about the jobperformance of ageing workers and its development.

In line with Ellström's (1997) conceptualization of “competence-in-use", jobcompetence is here understood as a process rather than an end state, and a person's potential, rather than something that an individual, or collective, has or has not (as can be the case with single skills). What we give of ourselves at our work at any time (competence-in-use), can vary a good deal from day to day and periodically in our lives, depending both on individual, job-related, and organizational factors. To an extent, then, a person's job-competence can be viewed as socially constructed (Ellström, 1997). Therefore, an assessment of job-performance of ageing workers is not only a matter of setting their particular knowledge, skills and attitudes/ aptitudes (OECD, 2013b) under the loop, but as importantly their job and organization-related aspects, including the social and socio-cultural context. 


\section{Job-performance of Ageing Workers}

Limited research, stereotypes prevail. Conceptual and methodological challenges are largely behind the limited research and thereby systematic, 'objective' knowledge on the overall job-performance of ageing workers. Consequently, much of the discussion has been colored by stereotypic thinking on ageing and older people. Age-stereotypes in the context of workplace can be powerful in influencing on both co-workers' attitudes and management's decisions on recruitment and layoff situations, as well as on human resources development and provision of jobrelated learning opportunities. As known, even older workers by themselves may carry and live these attitudes as self-fulfilling prophesy. The most commonly held stereotypes on older workers depicts them as with a decline in competence and vitality, on the one hand, and with gains in wisdom and experience on the other hand (Hummert, 2011). The former views have been dominating, especially concerning ageing workers in non-managerial positions, setting their jobperformance in ambiguous light (McDaniel et al., 2012; Posthuma \& Campion, 2009; Skirbekk, 2003). Negative attitudes are still widespread, especially among employers, and there is evidence of ageism even in the public employment services in several countries (Eurobarometer, 2012; Furunes \& Mykletun, 2007; OECD, 2006; Rix, 2005; Taylor \& Walker, 1994; Tikkanen, 2011b; Walker, 1997; Zaidi, 2008). Job-skills of older workers have been viewed as obsolete and/or lacking, their learning attitudes less positive, with weaker learning and other mental abilities, and they have been generally viewed less adaptable and as less fit for their work (Cedefop, 2010a; OECD, 2006; Posthuma \& Campion, 2009; Taylor \& Walker, 1994), particularly due to physiological decline and health limitations (Findsen, 2006) compared to their younger counterparts. However, stereotypes vary across cultures. For example Asian cultures have more positive views on ageing than Western countries (Hummert, 2011).

Often viewed as less productive, but the picture is ambiguous. Not surprisingly then, it is commonly believed, particularly by employers, that ageing workers are less productive than younger workers (Henseke \& Tivig, 2007; OECD, 2006; Posthuma \& Campion, 2009). Yet, there is no systematic knowledge on how age is related to productivity (Zacher et al., 2010). Indeed, measuring this relationship is complex (McDaniel et al., 2012), not least due to the broad spectrum of behaviors forming job-performance $(\mathrm{Ng} \&$ Feldman, 2008). Existing research suggests that there is a moderate positive relationship between age and performance (Waldman \& Avolio, 1986), that age is largely unrelated to performance (McEvoy \& Cascio, 1989), and that age-performance relationship has an inverted U-shape (Sturman, 2003, quoted in $\mathrm{Ng} \&$ Feldman, 2008). Reasons suggested for these different findings are that studies have focused on different behaviors, and overall, narrowly so, and that research methodology as well as data and data-collection characteristics have been different, e.g. focusing on different types of work within different research designs ( $\mathrm{Ng} \&$ Feldman, 2008). 
More coherent picture with meta-analyses, though methodological challenges prevail. To provide a more coherent picture of the age-performance relationship, $\mathrm{Ng}$ and Feldman (2008) carried out a large meta-analysis (380 studies reviewed), including ten dimensions of job-performance. They found out that age was generally unrelated to core tasks performance, creativity, and performance in training programs. A stronger relationship was revealed to the other seven dimensions. Job performance of older workers was more positive than that of younger workers in a number of key dimensions. Older workers were slightly more likely to help other employees (pro-social behaviour), more likely to comply safety rules, less likely to experience work injuries, less likely to participate in counterproductive work behaviour, less likely to be aggressive, less likely to participate in substance abuse, much less likely to be tardy or to be absent from work, and were slightly more likely to have sickness-related absences.

A more recent meta-analysis by McDaniel and colleagues (2012) showed that the message from the literature on age-related decline in capacities is clearer than that on the job-performance of older workers. Furthermore, an inverted Urelationship between age and job performance has been shown to be 'most likely' is in the area of cognitive aging (McDaniel et al., 2012: 280). While this view has dominated the research on age-stereotypes for over 30 years (Hummert, 2011), it has been criticized for some methodological weaknesses. This research shows that cognitive development (as human development overall) is highly individual, generally starting to take place on healthy individuals only after the age of 60 years or even 70 years, and it is strongly dependent on the job context and organizational factors, as well as individual lifestyle (Eurobarometer, 2012; Krampe \& Charness, 2006; Warr, 1994).

To illustrate the complex interrelatedness of age, job-performance and job characteristics, Warr (1994) has developed a simple taxonomy (Table 9.1).

Table 9.1. Warr's (1994) taxonomy of age, job performance, job characteristics. Adapted from McDaniel, Besta and Banks (2012).

\begin{tabular}{llll}
\hline $\begin{array}{l}\text { Job-related } \\
\text { capacities } \\
\text { decline with age }\end{array}$ & $\begin{array}{l}\text { Job experience } \\
\text { aids job } \\
\text { performance }\end{array}$ & $\begin{array}{l}\text { Relationship } \\
\text { between } \\
\text { performance and } \\
\text { age }\end{array}$ & Illustrative job content \\
\hline No & Yes & Positive & $\begin{array}{l}\text { Knowledge-based } \\
\text { judgments with no } \\
\text { time pressure }\end{array}$ \\
\hline Yes & Yes & No relationship & Skilled manual work \\
\hline Yes & No & Negative & $\begin{array}{l}\text { Continuous, paced } \\
\text { data processing }\end{array}$ \\
\hline No & No & No relationship & $\begin{array}{l}\text { Relatively } \\
\text { undemanding activities }\end{array}$ \\
\hline
\end{tabular}


The model introduces two moderators that interact with age to influence jobperformance. One is the extent of job-related capacities' decline with age, as discussed above, and the other the extent to which job experience affects jobperformance. The model suggests that in efforts to maintain older workers' job performance, it is important to work with these moderators.

Age-decline in skills proficiency? Findings from the new PIAAC-study (OECD, 2013a) provide a very recent, more nuanced and likely more reliable picture of older workers' skills compared to younger workers than perhaps any study ever before. The study is the largest ever skills survey conducted, comprising of $100,000+$ adults in 24 countries, and with a rigorous sampling design. It included a comprehensive background questionnaire, allowing for subjective skills/competence measurements. Furthermore, a comprehensive cognitive skill battery was included as an objective skills measure. These two allow for comparing objective and subjective measurements of skills/competence and their matches.

Skills proficiency was measured in regards literacy, numeracy and problemsolving in technology rich environments (PS-TRE). The findings showed a general, relatively steady decline in all three skills proficiency domains from the youngest (16 years) to the oldest age (65 years) after adjusting for educational attainment, language and foreign background. However, there was large variation across countries, although most variation was observed within countries. For example, in literacy Japan scored best of all countries in the oldest age group (55-65 years) and even better than the youngest (16-24 years) in the UK, Ireland, Italy, Spain and the USA. Further, gender differences in skills proficiency were found mainly among the older age groups (35 years and onwards), with women scoring lower than men in most countries.

In numeracy the age-trend was similar but the gap between youngest and oldest age groups was smaller than in literacy, and again the country differences were large and gender differences largest among the oldest (55-65 years). Worryingly, in two countries, the UK and the USA, numeracy proficiency among the oldest (5565 years) was higher than in the youngest age group (16-24 years). This suggests that their education systems have not improved at a rate comparable to that in other OECD countries.

When it comes to skills use at work (subjective measures), older workers used less information processing skills (comprising reading, writing, numeracy, ICT and problem-solving) than prime-age workers (25-54 years) but more than the youngest workers (16-24 years). Surprisingly, older workers used even more information and communication technology (ICT) skills than the youngest workers. The use of generic skills (task discretion, learning at work, skills in influencing, cooperation and self-organizing, dexterity, physical skills) was more common among older than prime-age workers.

When interpreting these results, one needs to keep in mind that, due to the crosssectional research design, the age-differences are not necessarily an indication of an evolvement of skills as a function of age. Rather they are colored by 
generational and cohort effects (e.g. development of educational systems throughout the times).

Ageing workers and skills mismatch. Besides skills as such, the thematic of skills mismatch has gained increasing attention the recent years. The rationale here is that skills, even high skills, alone do not turn into productivity unless they are put in proper use, matching with job's requirements (OECD, 2013a). This perspective is highly relevant in regards competence of older workers. If we are to believe the stereotypes of ageing workers, they should be more often underskilled (not adequate skills to perform their job) than overskilled (have skills to perform more demanding tasks than what the current job requires). Cedefop (2010a) has carried out a study of skills-mismatch of the "silver workers". Their findings showed that firstly, (self-reported) underskilling was lowest (around 10\%) among the oldest workers $(50+)$. Secondly, ageing workers were also less likely to be overskilled than prime age workers. However, when they held degrees, they were more likely to be overskilled than those with lower qualifications. Furthermore, overeducation (higher formal qualifications than work requires) was more prevalent for older than younger men.

More generally, skills obsolescence is shown to be more common in high-tech than low-tech industries, and greater among more educated workers. There is evidence that it is the type of education rather than its length that matters for skills obsolescence (less skills depreciation with academic than with vocational degrees), and that skills obsolescence is more strongly related to knowledge-based job tasks (especially technical knowledge) than experience-based job tasks (Cedefop, 2010a). Interestingly, while it is reasonable to expect training to contribute to new skills and skills development, as well as to a better skills-match, this does not seem to be the case. In Cedefop's (2010a) analysis, training did not reduce skills mismatch, nor lead to less underskilling. Furthermore, overeducated workers received training more often, but the relationship was less clear for ageing workers.

An area where skills mismatch (underskilling) of ageing workers is perhaps most salient is information technology (IT) and computer skills. The "grey digital divide" points to the gap between the actual and needed IT-skills among older adults, a gap expected to be widening in the future (Rizzuto, 2011). PIAAC (OEDC, 2013a) showed that in nearly all countries at least 10\% (range 7-27\%) of adults lack the most elementary computer skills (e.g. the ability to use mouse). Older people generally had lower proficiency in problem solving in technologyrich environments, but in some countries differences between older and younger people were very small.

In sum, the picture of the job-performance of older workers is ambiguous. There is some evidence for both age-increase and age-decline in regards the various jobrelated skills. In the absence of longitudinal studies on the age-relationship, again, we should be careful in making strong conclusions about the effects of age per se. Rather, job-performance of mature workers seems conditioned by the demand for and use of their skills in their job tasks, nature of work and industry, as well as by 
development opportunities at work, various organizational factors, and even the country where they work.

\section{Skills Diversity Promoting Innovation}

Human resources management will be increasingly challenged by a more diverse workforce, not only due to the ageing of the labour force, but also due to increased labour mobility and labour participation of women. Inasmuch, workforce diversity is important to creativity and innovation as suggested by the DUI (doing-usinginteracting) approach to innovations (Lorenz \& Lundvall, 2009; Lundvall \& Lorenz, 2012), great opportunities lie in this new situation. The diversity edge is at the core in knowledge management and in age-diversity management (agemanagement). Both aim at tackling the skills challenge, and the consequences from the demographic development to companies' skills pools, and their capability for knowledge creation and innovation (Cedefop, 2010a; Naegele \& Walker, 2006; Tikkanen, 2011a).

Clearly, employers' attitudes towards older workers and their views on productivity and capability beyond midlife (Zaidi, 2008), as well as their success in managing the workforce diversity will play a major role in to what extent ageing workforce will turn out to be opportunity rather than a threat (Tikkanen, 2011a). Indeed, employers' negative attitudes may have an adverse effect on the official efforts to promote the employment of older workers (Rix, 2005). Unfortunately, there is some evidence showing that stereotypes on ageing workers, held by management, are a main factor behind the modest result from age-diversity management in the new millennium (Furunes \& Mykletun, 2007).

\section{SKILLS DEVELOPMENT AND INNOVATION ABILITY IN EUROPE}

Productivity, skills, and continuous learning in and for work are highly interrelated. The EU strategic goals (benchmark) for participation in lifelong learning (LLL), formulated in the Education and Training 2020 Programme (ET2020) (EC, 2013), is set at an average of at least $15 \%$ of adults (age group 25-64). Several countries are already there, in particular in the Northern Europe, while many others still have a long way to go. Cooperation across the traditional disciplinary boundaries is called for in efforts to effectively combine LLL, innovation, creativity and entrepreneurship. In this chapter we will take a "cross-disciplinary" look at the situation of ageing workers in Europe, on the one hand, on the context of participation in LLL, including continuing vocational education and training (CVT), and in employment. On the other hand, we shall make national and crossnational comparisons of this performance against indicators of creativity and innovation used by economists. This analysis will, firstly, give us information about the status of ageing workers' participation in skills development in different countries. Secondly, it allows us to find out about possible connections between skills development and employment rates among ageing workers, on the one hand, and between their skills development and creativity and innovation, on the other 
hand. Thirdly, it allows comparison across European countries. The data is presented in Table 9.2.

\section{Ageing Workers' Participation in Skills Development in Europe}

Ranking of the countries in Table 9.210.2 is made on the basis of LLL participation among those aged 45-54 years. Participation rates are presented in three age groups: prime age workers (25-49 years) and younger-older (45-54 years) and older-older workers (50-74 years). Due to the categorizing that was available in Eurostat database, there is some age-overlap between the categories. The statistics show a negative relationship with age in LLL participation (Table 9.2). Secondly, there is key variation in LLL participation across the Europe. Thirdly, the countries can be grouped into four different levels according to their participation rates in the age-group 45-54 years. The highest rates, from above $20 \%$ to closer $30 \%$, are found in the Nordic countries, with the exception of Norway. The second group comprises of countries with participation rates between 15 and 20\% (NO, FR, UK, $\mathrm{NL}$ ), and the third from closer to $10 \%$ to less than $15 \%$ (LU, AT, SL, CR, ES, EE, PT). The remaining countries with lowest participation rates, about $5 \%$ and below, present half of all the remaining countries. As LLL here refers to all education and training in general, the rates for participating in $\mathrm{CVT}^{1}$ provided by employers in enterprises, are shown separately. CVT is likely to be the most important channel for skills development of older workers.

Table 9.2. Participation rates in lifelong learning $(L L L)^{A}$ and continuing vocational training (CVT) by age, innovation performance, as well as employment rates of older workers in Europe. Ranking by the LLL participation in the age-group 45-54 years (in \%).

\begin{tabular}{|c|c|c|c|c|c|c|c|}
\hline \multirow{3}{*}{ Country } & \multicolumn{4}{|c|}{ Participation } & \multirow{3}{*}{$\begin{array}{c}\text { Employ- } \\
\text { ment } \\
\text { rate } \\
55-64 \\
\text { yrs }\end{array}$} & \multirow{3}{*}{$\begin{array}{c}\text { Innovation } \\
\text { performance } \\
(2014)^{\mathrm{B}}\end{array}$} & \multirow{3}{*}{$\begin{array}{c}\text { Creative } \\
\text { workers from } \\
\text { population }\end{array}$} \\
\hline & \multicolumn{3}{|c|}{ Lifelong learning } & $\mathrm{CVT}^{\mathrm{D}}$ & & & \\
\hline & $25-49$ & $\begin{array}{l}45-54 \\
\text { (rank) }\end{array}$ & $\begin{array}{l}50-74 \\
(2013)\end{array}$ & $\begin{array}{l}55+\text { yrs } \\
(2005)\end{array}$ & & & \\
\hline EU28 & 12.6 & 8.7 & 8.2 & (33) & 50.1 & Moderate & $51^{\mathrm{C}}$ \\
\hline Denmark & 35.5 & 28.7 & 26.1 & 38 & 61.7 & Leader & 70 \\
\hline Sweden & 31.8 & 25.8 & 21.6 & 41 & 73.6 & Leader & 82 \\
\hline Finland & 30.0 & 24.0 & 20.0 & 38 & 58.5 & Leader & 66 \\
\hline Iceland & 28.9 & 23.0 & 19.9 & n.a. & 81.1 & Follower & n.a. \\
\hline Norway & 23.9 & 18.1 & 15.7 & 39 & 71.1 & Moderate & n.a. \\
\hline France & 20.3 & 16.6 & 14.7 & n.a. & 45.6 & Follower & 63 \\
\hline UK & 18.1 & 15.8 & 13.5 & 30 & 59.8 & Follower & 51 \\
\hline
\end{tabular}


LIFELONG LEARNING AND SKILLS DEVELOPMENT IN THE CONTEXT OF INNOVATION

\begin{tabular}{|c|c|c|c|c|c|c|c|}
\hline Netherlands & 20.9 & 15.2 & 13.3 & 27 & 60.1 & Follower & 67 \\
\hline Luxembourg & 17.6 & 12.1 & 8.1 & 39 & 40.5 & Follower & 60 \\
\hline Austria & 17.1 & 11.5 & 9.3 & 25 & 44.9 & Follower & 50 \\
\hline Slovenia & 15.7 & 9.2 & 9.9 & 37 & 33.5 & Follower & 50 \\
\hline $\begin{array}{l}\text { Czech } \\
\text { Republic }\end{array}$ & 11.8 & 8.7 & 7.8 & 60 & 51.6 & Moderate & 40 \\
\hline Spain & 13.2 & 8.2 & 6.9 & 36 & 43.4 & Moderate & 35 \\
\hline Estonia & 16.4 & 8.1 & 6.7 & 19 & 62.6 & Follower & 58 \\
\hline Portugal & 12.6 & 7.3 & 5.7 & 31 & 46.7 & Moderate & 46 \\
\hline Belgium & 8.2 & 5.4 & 5.6 & 37 & 41.7 & Follower & 60 \\
\hline Ireland & 8.7 & 5.3 & 3.7 & n.a. & 51.3 & Follower & 58 \\
\hline Germany & 10.6 & 5.0 & 3.7 & 27 & 63.5 & Leader & 52 \\
\hline Malta & 9.9 & 4.9 & 5.4 & 39 & 35.9 & Moderate & 70 \\
\hline Latvia & 8.2 & 4.5 & 4.1 & 14 & 54.8 & Modest & 53 \\
\hline Cyprus & 8.5 & 4.4 & 4.4 & 20 & 49.6 & Follower & 42 \\
\hline Italy & 7.7 & 4.3 & 4.9 & 38 & 42.7 & Moderate & 37 \\
\hline Lithuania & 7.3 & 3.8 & 3.5 & 16 & 53.4 & Moderate & 35 \\
\hline Poland & 6.3 & 2.1 & 1.9 & 23 & 40.6 & Moderate & 43 \\
\hline Slovakia & 3.8 & 1.8 & 1.9 & 48 & 44.0 & Moderate & 33 \\
\hline Hungary & 4.3 & 1.8 & 1.2 & 13 & 38.5 & Moderate & 44 \\
\hline Greece & 4.1 & 1.4 & 2.1 & 15 & 35.6 & Moderate & 39 \\
\hline Romania & 2.7 & 1.1 & 1.7 & 21 & 41.5 & Modest & 35 \\
\hline Croatia & 4.4 & 0.6 & 0.8 & n.a. & 36.5 & Moderate & n.a \\
\hline Bulgaria & 2.6 & n.a. & n.a. & 21 & 47.4 & Modest & 39 \\
\hline
\end{tabular}

A) Lifelong learning refers to persons of the indicated age-groups who stated that they received education or training in the four weeks preceding the survey (EC, 2013). ${ }^{\text {B) }}$ Innovation Union Scoreboard (IUS) 2014 (EC, 2014b). ${ }^{\text {C) }}$ Creativity at work in EU27 (Lorenz and Lundvall, 2009); ${ }^{D}$ As a percentage of employees in enterprises. Source: Eurostat/EC (2014b) ${ }^{\text {B }}$ - Updated from Tikkanen (2011a) (Cedefop, 2010b). 
Compared to LLL, the cross-country differences in the participation rates of ageing workers (55+) are smaller and the rate of older workers' participating in CVT throughout Europe is generally higher. The highest rates are found in Czech Republic (60\%) and Slovakia (48\%). The next level, participation around $40 \%$, is common in a range of countries, while in the remaining countries the rates vary between around 13 and 30\%. Clearly, Europe seems still divided into several layers when it comes to making LLL a reality, not only but also for its ageing population.

\section{Skills Development and Employment Rates vs. Creativity and Innovation}

The employment rates of ageing workers (55-64 years) in Europe show also large cross-country differences (Table 9.2 ). The highest rates (70-80\%) are found again in the Nordic countries. There are a range of countries with employment rates around $60 \%$, followed by those on around $30-40 \%$. The cross-country differences are smaller than with LLL. Yet, there seems to be a positive relationship between ageing workers' employment rates and their participation in LLL in Europe. Finally, Table 9.2 allows us to compare the participation rates in skills development and employment of ageing workers with innovation performance and creativity. For innovation performance the Innovation Union Scoreboard (IUS) 2014 (EC, 2014b) rankings were used (for the sets of performance indicators, see EC, 2014b).

Of the four levels, the best performing countries, Innovation Leaders, are highlighted in the table (EC, 2014b). Creativity is also used to indicate a country's innovation performance. The measure is developed by Lorenz and Lundvall (2009). It describes a nation's 'capacity for knowledge development' with a range of variables (problem-solving activities, learning new things, undertaking complex tasks, using one's own ideas, able to choose one's work methods and the order of one's tasks). Creative workers were those scoring high (high activity) in these variables. The measure is based on the fourth European Working Conditions Survey from 2005 (European Foundation, 2007), and shows the proportion of creative workers from the country's population.

Innovation performance varies greatly across the countries (Table 9.2). The variation in creativity seems less pronounced, yet notable. Interestingly, with the exception of Germany, all Innovation Leaders are also countries where the rates for LLL and ageing workers' employment are among the highest, as are the rates of creative workers in the population. Correspondingly, the countries with lowest innovation performance (Modest Innovators) are also countries were participation in LLL and CVT of ageing workers are among the lowest. The performance of Germany, one of Europe's four Innovation Leaders, ranks on a European average in creavity and skills development, thus with a large difference to the other three Innovation Leader countries. Lorenz (2012) has suggested that an explanation to this may be related to the different welfare regimes between the Nordic countries and Germany: the latter with a conservative welfare regime, while in the former a combination of active labour market policies through lifelong learning and continuous vocational training "to promote mobility of workers from unproductive 
to productive occupations and sectors" (Lorenz, 2012: 77). Furthermore, the "flexibility of [the Nordic countries'] local labour markets, which promote diversity in the enterprise knowledge base", as Lorenz (2012: 77) suggests, may be related to their success in innovation (high-tech sectors, ICT). The higher rates of ageing workers' employment rate in those countries may be a reflection of this.

A deeper analysis of these interesting intersections is beyond the scope of this paper. What we can conclude here is that although the data presented in Table 9.2 comes from different sources, they seem consistent: in the countries which succeed in linking LLL, innovation and creativity, also older workers' participation is high in learning and work.

\section{METHODOLOGY}

\section{Data}

The study presented here is part of an ongoing (2014-2017) research project, Skills development for realizing the workforce competence reserve (SkillsREAL), financed by the Norwegian Research Council. The data used in SkillsREAL and the analysis presented in this paper are from the Programme for the International Assessment of Adult Competencies (PIAAC) by OECD (2013a). PIAAC is continuation to the previous adult education surveys by OECD: the Adult Literacy and Lifeskills Survey (ALL) and the International Adult Literacy Survey (IALS). The data was collected face-to-face through interviews from around 166.000 adults, aged 16-64 years, from more than 20 countries (OECD, 2013a). The analysis presented here is limited to those aged 40-65 years and currently working and by country/region. We selected only those PIAAC countries, which were also included in the IUS in Europe (EC, 2014b). This selection resulted in a total sample size of about 45000 .

\section{Measures}

The variables included in the analysis are from the PIAAC background questionnaire (OECD, 2013a). Dependent variables are learning needs at work and job-related skills development practice. Two variables were chosen to measure learning needs: a general measure "Do you feel that you need further training in order to cope well with your present duties?" (y/n), and a specific measure related to use of information and communication technology (ICT) at work: "Do you think you have/had the computer skills you need/needed to do your job/last job well?" $(\mathrm{y} / \mathrm{n})$. Skills development practices were measured with two questions. One was participation rates in formal or non-formal education and training for job-related reasons $(\mathrm{y} / \mathrm{n})$. The second was a sum-indicator built from three questions about jobrelated learning. These questions covered intensity ("how often ...") of learning at work from co-workers or supervisors, from learning-by-doing (from the job-tasks performed), and about keeping updated with new products or services. A Likertscale was used for answers: never $(=1)$, less than once a month $(=2)$, less than once 
a week but at least once a month $(=3)$, at least once a week but not every day $(=4)$, and every day (=5). A new combined variable (LEARNACTIVE) was formed from these by summing them up. The sum-variable was scaled back to a range of 1-5.

Age and innovation performance clusters were used as independent variables. Education, gender and type of work were used as controls. For age, the PIAACvariable AGEG5LFS was used, grouping age into 5-year intervals (40-44, 45-49, 50-54, 55-59, 60-65 years). For education, the PIAAC derived variable EDLEVEL3 was used: 'low' level covered ISCED categories from 1 to 3 (shorter than two years), 'medium' categories 3 (2 years or more) to 4, and 'high' categories 5 to the 6A (PIAAC Background Questionnaire). For type of work, four occupational skill level categories were used (PIAAC derived variable ISCOSKIL4): skilled (=1), semi-skilled white-collar (=2); semi-skilled blue-collar $(=3)$, and elementary occupations $(=4)$. The categories were based on the International Standard Classification of Occupations (ISCO) by the International Labour Organization (ILO). Distributions of these variables by age are shown in Table 9.3. All variables showed a statistically significant relationship with the age (Chi-square for all sig. at $\mathrm{p}<.001$ ).

Table 9.3. Distributions of the background variables by age-groups (\%) (all $\left.X^{2} p<.001\right)$.

\begin{tabular}{|c|c|c|c|c|c|c|}
\hline \multirow{2}{*}{ Variable } & \multicolumn{5}{|c|}{ Age-groups (years) } & \multirow[b]{2}{*}{ All } \\
\hline & $40-44$ & $45-49$ & $50-54$ & $55-59$ & $60-65$ & \\
\hline \multicolumn{7}{|l|}{ Innovation Performance } \\
\hline Leaders & 22.2 & 22.8 & 20.8 & 18.6 & 15.5 & 100 \\
\hline Followers & 25.2 & 24.8 & 22.0 & 18.8 & 9.2 & 100 \\
\hline Moderate & 27.2 & 26.1 & 21.7 & 16.5 & 8.5 & 100 \\
\hline \multirow[t]{2}{*}{ Gender } & 25.9 & 25.9 & 21.9 & 17.8 & 8.5 & 100 \\
\hline & 26.1 & 24.9 & 21.7 & 17.3 & 10.1 & 100 \\
\hline \multirow{4}{*}{$\begin{array}{r}\text { Type of work Skilled } \\
\text { Semi-skilled white-collar } \\
\text { Semi-skilled blue-collar } \\
\text { Elementary }\end{array}$} & 26.4 & 24.6 & 22.0 & 17.5 & 9.6 & 100 \\
\hline & 26.5 & 24.7 & 22.9 & 16.9 & 9.0 & 100 \\
\hline & 26.1 & 26.0 & 21.6 & 18.1 & 8.2 & 100 \\
\hline & 23.8 & 28.1 & 19.4 & 18.9 & 9.7 & 100 \\
\hline \multirow[t]{3}{*}{ Education } & 21.8 & 24.5 & 21.0 & 20.1 & 12.6 & 100 \\
\hline & 25.2 & 26.2 & 23.0 & 17.9 & 7.7 & 100 \\
\hline & 31.1 & 24.6 & 20.4 & 14.6 & 9.2 & 100 \\
\hline
\end{tabular}

The selected (PIAAC and IUS) countries were grouped into three clusters according to their innovation performance in the IUS. Besides that clustering made the analyses less complex, main points of departure here were that lifelong learning and skills development are considered crucial for countries innovation ability in the learning economy (Lundvall \& Lorenz, 2012) and that "knowledge excellence" has 
been found as one of the factors causing large differences between the EU Member States (EC, 2014b). Based on their innovation performance, measured with 25 indicators (see EC, 2014b: 10), the IUS 2014 ranked the European Union Member States into the following four groups: (1) "Innovation leaders" (Denmark, Finland, Germany, Sweden) with their innovation performance well above the EU average; (2) "Innovation followers" (Austria, Belgium, Cyprus, Estonia, France, Ireland, Luxembourg, the Netherlands, Slovenia, United Kingdom) with their innovation performance above or close to the EU average; (3) "Moderate innovators" (Croatia, Czech Republic, Greece, Hungary, Italy, Lithuania, Malta, Norway, Poland, Portugal, Slovakia, Spain) with their innovation performance below the EU average; (4) "Modest innovators" (Bulgaria, Latvia) with their innovation performance well below the EU average (EC, 2014b).

As a consequence from matching the country selection with the PIAAC survey participants, not all IUS-countries were included in our analysis. None of the countries from the last group, Modest innovators, participated in the PIAAC. Therefore, only three European innovation clusters were formed. The countries included in each cluster, is shown in Figure 9.1.

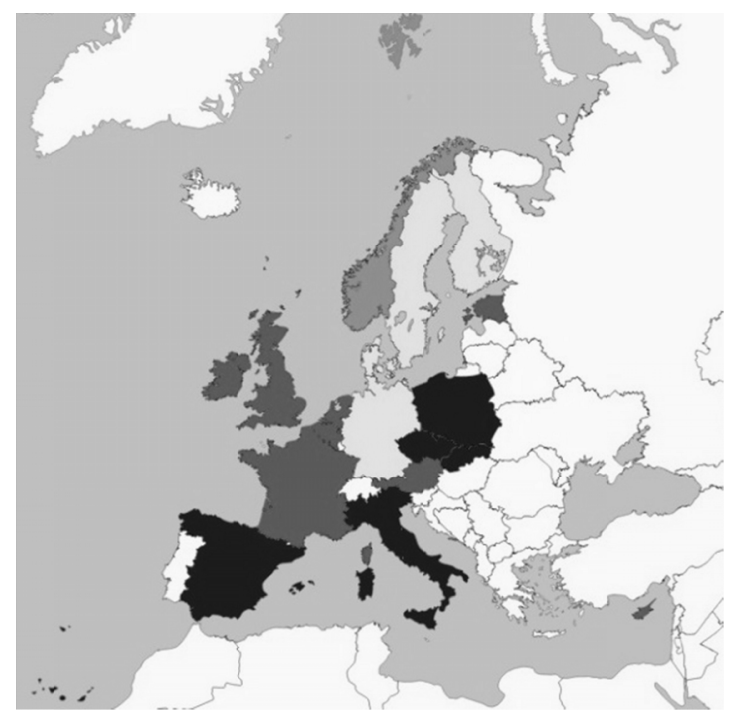

Figure 9.1. Innovation performance clusters in the analysis. Elaborated from IUS (EC, 2014b) and PIAAC (OECD, 2013a).

\section{Data Analysis}

While Norway actually ranks among the Moderate innovators in the IUS (EC, 2014 b), in the analyses here it has been placed among Innovation followers. This is 
because in terms of education, Norway performs on the level closer to the Moderate innovators (EC, 2014b). Furthermore, the country's performance in the PIAAC is closer to the other Nordic countries (Innovation leaders in the IUS) than the rest of the European countries (OECD, 2013a). For the current analyses, a new Innovation Region variable was created, comprising of the three European innovation clusters described above. All the PIAAC questions and variables are described in detail in the report PIAAC Background questionnaire (OECD, 2010b).

Data was analyzed using the Statistical Package for the Social Sciences (SPSS). Chi-square tests were used to explore bivariate associations between dependent, independent and controlling variables. A binary logistic regression analysis using SPSS was carried out to examine the effects of the innovation regions and age categories on learning needs (general and ICT-specific) and skills development (learning participation). Multiple linear regression was used to explore differences between innovation regions and age categories on the frequency of learning activities at work (combined variable). Regression models (binary logistic and multiple linear) explored main effects of innovation regions and age category. The models were analyzed both unadjusted and adjusted for gender, education and type of occupation (occupational skill level). Regression analyses used an adjusted weight created using the PIAAC final full replicate weight (SPFWT0), adjusted to the restricted sample size.

\section{RESULTS}

\section{Learning Needs}

The questions used to assess learning needs were need for training in order to cope well with one's present duties and having the computer skills to do one's job well or not. Overall, need for training was not very prevalent, reported by only about a third of all the respondents (mean 32.5\%) (Figure 9.2). Age had a statistically significant effect on training needs, overall, and separately in all innovation groups. Training needs were reported twice as often (close to $40 \%$ ) by the youngest (40-44 years) compared to by the oldest employees (60-65 years) in all innovation groups $(21 \%)$. The youngest were more than twice as likely to have training needs as the oldest, even after adjusting for gender, education and type of occupation. Controlling for gender did not have an effect in the two best performing innovation groups (Leaders and Followers), but did so among the Moderate innovators $(\mathrm{p}<.05)$.

The age differences in training needs across innovation performance clusters were not very large (Figure 9.2), but they were still statistically significant. In the oldest age group only about one in five of the Innovation Leaders and Followers, and one in four of the Moderate Innovators reported training needs. Both in the youngest and two oldest age groups the training needs were most often reported in the least innovative countries (Moderate Innovators), although the difference was not very large (3-4 percentage units). Also after adjusting for gender, education and 
type of occupation, Moderate Innovators were 1.4 times more likely to report of training needs than the Innovation Leaders.

There were also some differences in the pattern of the decrease in training needs by age across the three innovation performance groups (Figure 9.2). Among the Innovation Followers, the decline started from the age 50 years while among Innovation Leaders somewhat later, from the age of 55 years. Among the Moderate Innovators the training needs were dropping first steadily until the 50 years of age, then platooning until 59 years, and thereafter declining again.

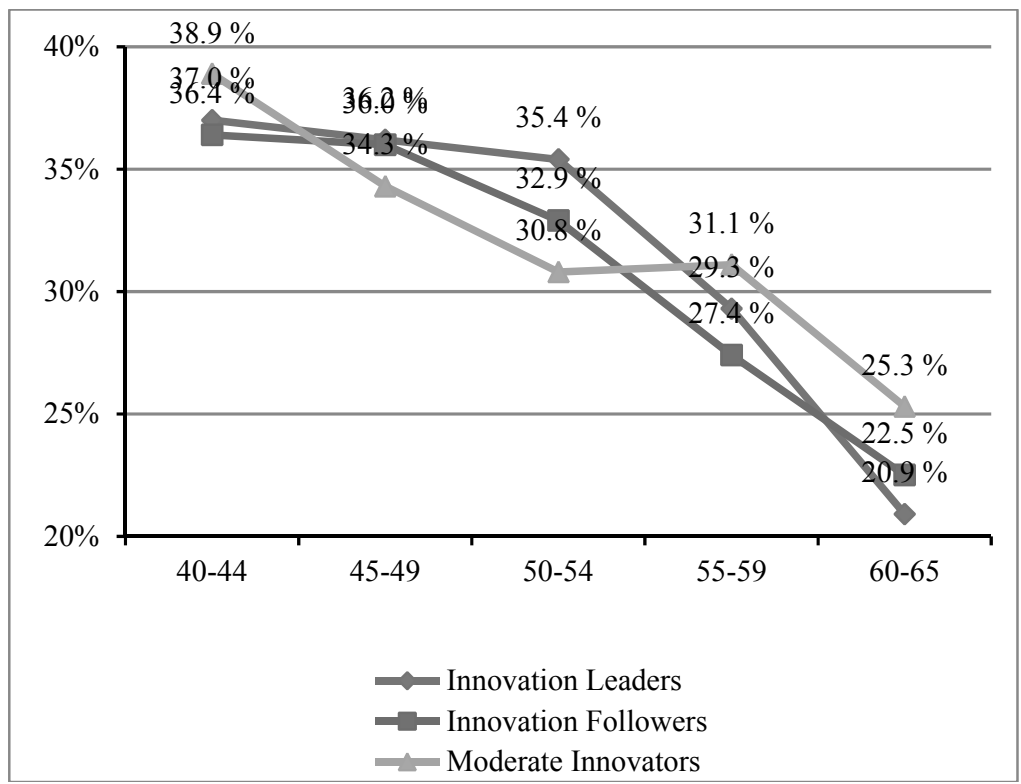

Figure 9.2. Need for more training by age and innovation performance (\% yes). Data: PIAAC.

A great majority (87\%) of all the respondents had the computer skills needed to do their job well. Conversely, the rate of those not having the computer skills needed to do their job well (Figure 9.3) was modest (13\%). Not unexpectedly, age did have a statistically significant, positive effect on the lack of computer skills, overall and in each innovation group. Compared to the youngest age group, the two oldest age groups were 1.6-1.7 times more likely to report of not having sufficient computer skills after adjusting for gender, education and type of occupation.

Also innovation performance was related to the lack of computer skills (Figure 9.3). There was a clear level difference between the Moderate Innovation countries and countries in the two best performing innovation clusters. Moderate innovators were significantly $(\mathrm{p}<.05)$ less likely, while Innovation Followers were 
significantly $(p<.05)$ more likely to report of lacking computer skills in their work than Innovation Leaders, after adjusting for gender, education and occupational type. The fact that lack of computer skills was least often (mean 9.8\%) reported in countries with lowest innovation performance (Moderate Innovators), across all age groups, is likely to be related to less access to/use of computers at work in these countries than in the countries with better innovation performance (mean $14 \%$, both clusters).

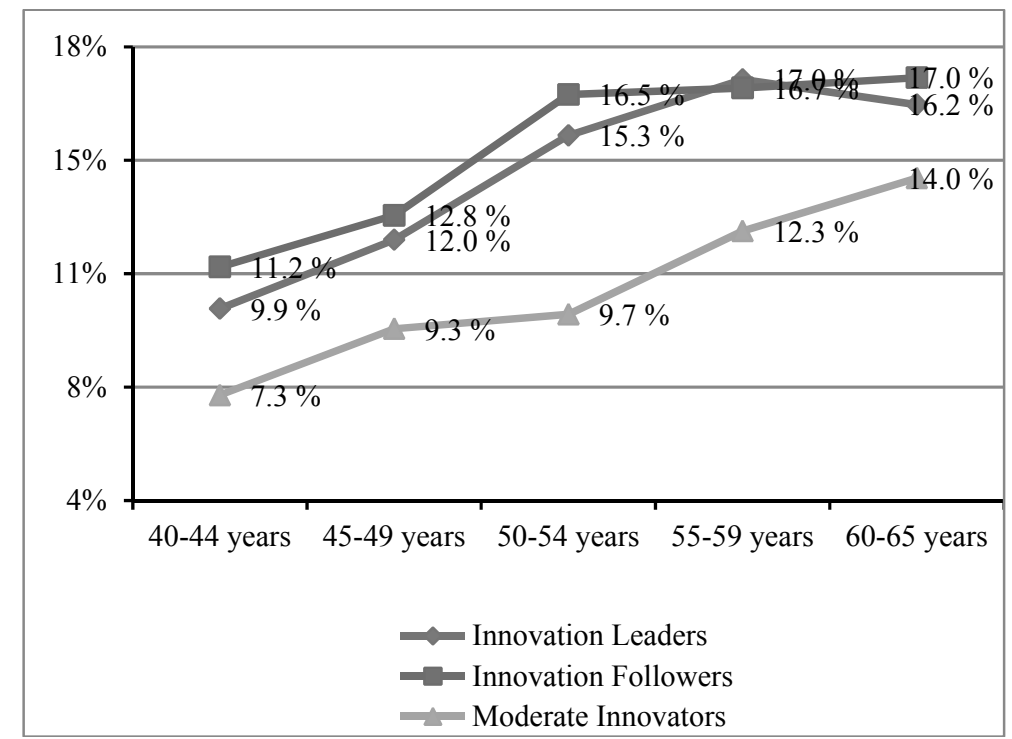

Figure 9.3. Rate of those not having the computer skills needed to do one's job well, breakdown by age and innovation performance. Data: PIAAC.

Lack of computer skills was reported least often of all (7.3\%) by the youngest in the Moderate Innovator countries, and most often $(17 \%)$ in the oldest in the Innovation Follower countries.

\section{Skills Development}

Skills development was measured by two variables. The first was participation rate in formal or non-formal education and training (E\&T) for job-related reasons. The majority $(65.7 \%)$ of the respondents had not participated in this kind of training. As could be expected from earlier cross-sectional studies (for an analysis, see Tikkanen, 1998), age had a significant negative effect on participation in E\&T, also after the controls (Figure 9.4). People in the youngest group (40-44 years) had participation rates several fold higher than in the oldest age group (60-65 years), the ratio increasing with decreasing innovation performance. Compared to the oldest age group (60-65 years), the youngest people (40-44 years) were 2.26 times 
more in the Innovation Leader countries, and 3.3 and 4.5 times more among the Innovation Followers and Moderate innovators respectively, to participate in training. After controlling for gender, education and type of work, people in the youngest age group were still more than twice more likely to participate in training than people in the oldest age group (Figure 9.4).

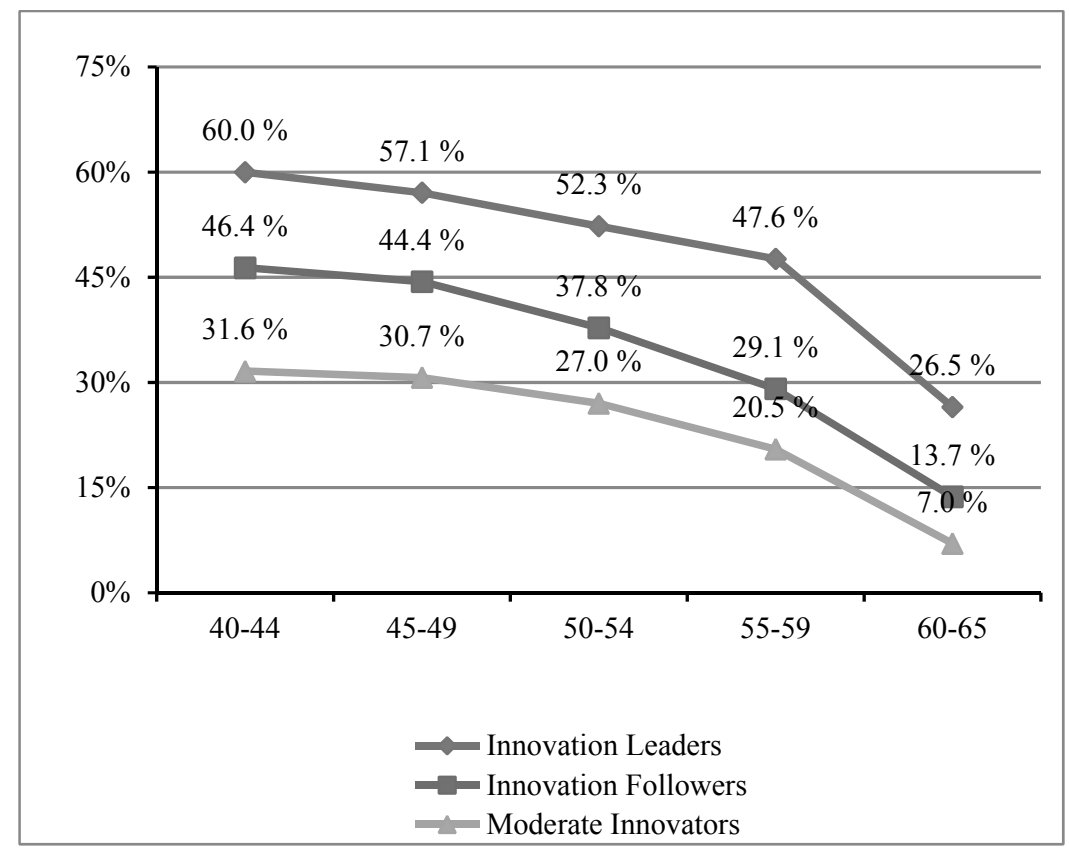

Figure 9.4. Participation in formal or non-formal education and training for job-related reasons by age and innovation performance (\%). Data: PIAAC.

There was also a significant relationship between training participation and country clusters' innovation performance (Figure 9.4). The average participation rate was the highest among the best innovation performers (Innovation Leaders), $47.1 \%$, followed by Innovation Followers and Moderate Innovators, 34 and 22.5\% respectively. In the youngest age-group, participation rate in the Innovation Leader countries was about two times higher $(60 \%)$ than among Moderate Innovators $(31.6 \%)$, while in the oldest group it was almost four times higher $(26.5 \mathrm{vs} .7 \%)$. After controlling for gender, education and type of work, Innovation Leader countries were more than three times more likely to participate in formal and nonformal E\&T for job-related reasons than Moderate Innovators ${ }^{2}$ (Figure 9.4).

The second variable measuring skills development practices was intensity of learning activities at work. This was a combined measure with an overall mean 3.2 (s.d.=1.04). To some extent the results resemble those for E\&T participation rates. 
Age had a negative effect in reported learning intensity at work (Figure 9.5). The age differences in the mean scores were statistically significant $(\mathrm{p}<.001)$ in all three innovation groups.

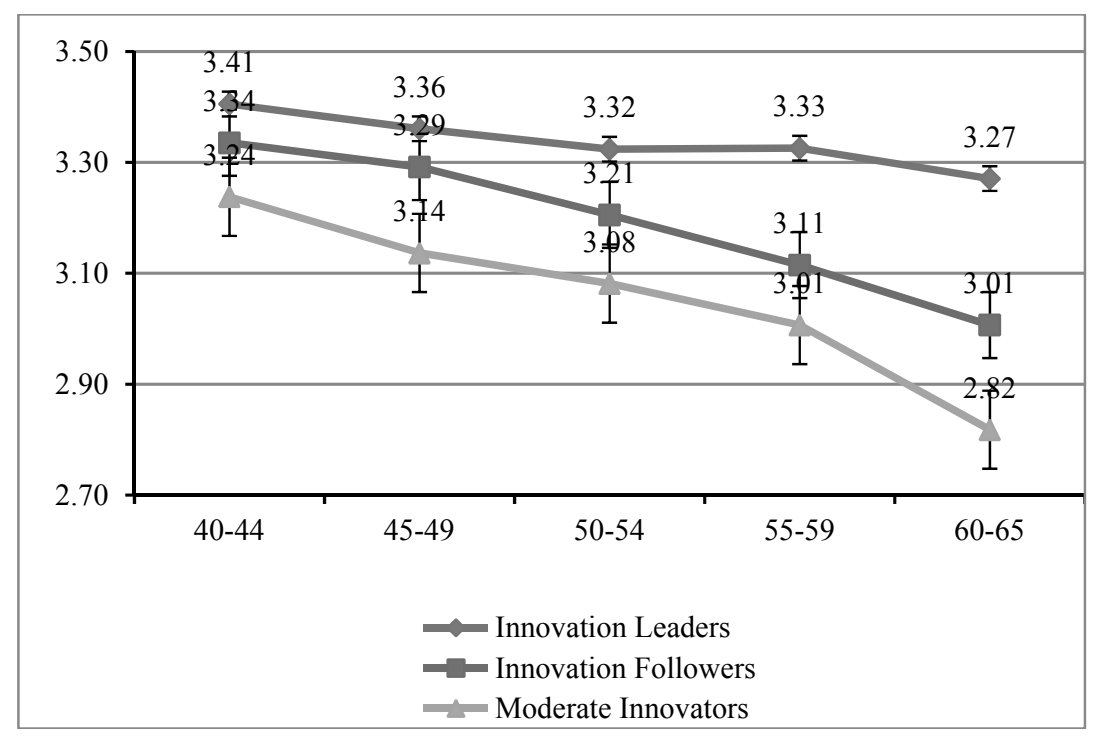

Figure 9.5. Intensity of learning activities at work (combined measure) by age and innovation performance groups. Data: PIAAC.

Learning intensity at work was highest among the Innovation Leaders, followed by Innovation Followers, and being the lowest among Moderate Innovators, in all age groups. In the Innovation Leader countries intensity of workplace learning is above the mean (3.2) also in the oldest age groups. In the Innovation Follower countries the learning intensity declines below the average about after the age of 50 , in the Moderator countries it is below the average in all but the youngest age group. The standard deviations were smallest in the Innovation Leader countries (s.d.=.93), and largest in the Moderate Innovator countries (s.d.=1.15). The agepatterns in learning intensity were quite similar among the countries in the two lower innovation performers (Followers and Moderate). However, there was a level difference between them. In the Innovation Leader countries the age-decline in learning intensity at work was the smallest, and significantly different from the two other innovation groups.

The effects of both age and country clusters' innovation performance on learning intensity at work were statistically significant $(p<.001)$, also after controlling for gender, education and type of work (Table 9.4). 
Table 9.4. Binary logistic regression model for not having the required computer skills to perform one's job satisfactorily.

\begin{tabular}{|c|c|c|c|c|}
\hline & \multicolumn{2}{|c|}{ Learning needs } & \multicolumn{2}{|c|}{ Skills development } \\
\hline & General & ICT & AET ppt & $\begin{array}{l}\text { Learning } \\
\text { at work }\end{array}$ \\
\hline & $\mathrm{OR}^{\wedge}$ & $\mathrm{OR}^{\wedge}$ & $\mathrm{OR}^{\wedge}$ & $\mathrm{b}^{\wedge}$ \\
\hline Age (Ref: 40-44 yrs) & $* * *$ & $* * *$ & $* * *$ & $\begin{array}{c}- \\
0.071 * * *\end{array}$ \\
\hline $45-49$ & $0.912 * *$ & 1.098 & 1.029 & \\
\hline $50-54$ & $0.801 * * *$ & $1.372 * * *$ & $0.901 * *$ & - \\
\hline $55-59$ & $0.668 * * *$ & $1.663 * * *$ & $0.763 * * *$ & - \\
\hline $60-65$ & $0.430 * * *$ & $1.761 * * *$ & $0.425 * * *$ & - \\
\hline EU Innov. Region (Ref: Leader) & $* * *$ & $* * *$ & $* * *$ & \\
\hline Follower & $0.839 * * *$ & $1.185^{*}$ & $0.430 * * *$ & $\begin{array}{c}- \\
0.149 * * *\end{array}$ \\
\hline Moderate & $1.365 * * *$ & $0.855^{*}$ & $0.348 * * *$ & $\begin{array}{c}- \\
0.223 * * *\end{array}$ \\
\hline Gender (Ref: Male) & & & & \\
\hline Female & 0.974 & $1.109^{*}$ & 0.989 & $\begin{array}{c}- \\
0.078 * * *\end{array}$ \\
\hline Education (Ref: Low) & & $* * *$ & $* * *$ & \\
\hline Medium & $1.333 * * *$ & $0.869 *$ & $1.583 * * *$ & $0.074 * * *$ \\
\hline High & $1.553 * * *$ & $0.711 * * *$ & $3.087 * * *$ & $0.258 * * *$ \\
\hline Occupation type (Ref: Elementary) & $* * *$ & $* * *$ & $* * *$ & \\
\hline Skilled & $2.706 * * *$ & 0.797 & $4.310^{* * *}$ & $0.871 * * *$ \\
\hline While-collar & $1.848 * * *$ & $0.704 * *$ & $2.067 * * *$ & $0.612 * * *$ \\
\hline Blue-collar & $1.499 * * *$ & $1.449 * *$ & $1.428 * * *$ & $0.284 * * *$ \\
\hline Model & & & & \\
\hline Constant (b) & -1.633 & -1.755 & 0.476 & 3.216 \\
\hline Nagelkerke $\mathrm{R}^{2}$ & 0.072 & 0.031 & 0.220 & 0.118 \\
\hline
\end{tabular}

$*<0.05 ; * * \leq 0.01 ; * * * \leq 0.001$. $^{\wedge}$ Not applicable for Constant

(b) and Nagelkerke R2

\section{DISCUSSION}

The purpose of this study was to give new knowledge on job-related learning needs and skills development among ageing workers in the context of innovation performance in Europe. The results showed that age was a significant moderator of learning needs and skills development, even after controlling for education, gender and type of occupation. The oldest workers (55-65 years) reported least often learning needs and skills development activity. The only exception was computer skills. Training needs were the highest (36-39\%) in the youngest age group (40-44 years), while lack of computer skills was highest (16-17\%) in the oldest age group (60-65 years). Skills development by participation in E\&T was on a moderate level; about a third of the respondents had participated in formal or non-formal 
education and training (E\&T) for job-related reasons during the last 12 months. Skills development through informal workplace learning was more intensive.

On the one hand, the findings support some of the common views (stereotypes) on ageing workers and learning, as described in the first part of this article. On the other hand, the findings support earlier research, showing for example that underskilling is the lowest among older workers 50+(Cedefop, 2010a). The lack of skills in computer use at work was more pronounced in the oldest age groups, yet still on a rather modest extent. It may be that compute use in workplaces is only required on rather simple level for most ageing workers, and they master it. It is also possible that ageing workers have better computer skills as required by their jobs, than what the stereotypic views tend to suggest. This was also implied by the overall PIAAC findings, which showed that older adults use ICT more than younger adults (OECD, 2013a). When the job-related learning needs are as moderate as shown in this study, it is perhaps not surprising that raising the LLL participation rates towards the EU2020 benchmark remains a challenge (EC, 2013). However, learning at work was more intensive, although with large variation across, and within, countries. The Education and Training Monitor in Europe showed corresponding findings (EC, 2013).

The cross-disciplinary study presented in this article was rather experimental in that it contextualized the more common analysis of the age-learning-skills relationship on innovation performance in Europe. The findings were interesting, although they should be taken only indicative for further research. There were significant differences in the age-patterns and the levels of learning needs and skills development practice across the three innovation clusters, even after controlling for education, gender and type of occupation. In all age groups shortages in computer skills at work were lowest in the countries with lowest innovation performance (Moderate Innovators). In Innovation Leader countries also older workers were more active in skills development, especially in informal learning at work, than in countries with lower innovation performance. This finding is not surprising, given that of the four Innovation Leader countries three are Nordic countries (DK, SE, FI), which generally outperform other European countries in learning participation, especially in the older age groups (EC, 2013; OECD, 2013a). Germany, the fourth Innovation Leader country, generally performs only on a European average level when it comes to employees' engagement in creative work activity (Lorenz \& Lundvall, 2009), as well participation in LLL and CVT, and below the average in older age groups. Thus, Germany has had an impact on the performance of the Innovation Leaders in this study, but the impact may have been less than could have been expected.

The findings give support to the link between skills development and countries' innovative performance found in earlier research (Cedefop, 2012a; Lorenz \& Lundvall, 2009). Countries, with high innovation performance, tended also to have higher participation rates in learning and work, also among ageing workers, than countries with lower innovation performance. Besides with measures on learning and creativity, the link has also shown to exist when using more classic measures of innovative performance (e.g. number of patent applications) (Lorenz \& 
Lundvall, 2009). Though the analysis here does not allow for causal relationships, the findings suggest that also ageing workers can make an important contribution to innovation activity and productivity. In high-innovation countries the higher levels of participation in continuous learning and E\&T of ageing workers, is likely to help them to maintain their job-performance. In return, their experience-based competence contributes to competence diversity in their workplaces, potentially helping to foster innovative activity. Earlier research has suggested that women may need specific attention in this context: they are only about $40 \%$ as likely to be engaged in creative work activity as men (Lorenz \& Lundvall, 2009).

In order to keep the ageing workers motivated to learn and work, a precondition is that work invites to and stimulates learning. However, not all workplaces are learning-intensive or even learning-friendly (Cedefop, 2012a), some environments being enabling and some constraining (Ellström, 2011). This may particularly be the case with ageing workers. Future research should explore learning needs of ageing workers and their job performance in relation to different sectors and types of work. For, as pointed out by Lorenz and Lundvall (2009), the most important bottleneck to improved innovation capability and performance in Europe may not be so much about the level of R\&D investments, as organizations' ability to "provide a fertile environment for learning and problem-solving", to stimulate "pro-innovation organizational practice" (Lorenz \& Lundvall, 2009: 176).

\section{NOTES}

1 CVT refers to persons employed by enterprises with the following qualifying criteria: "the training must be planned in advance; the training must be organized or supported with the specific goal of learning; the training must be financed at least partly by the enterprise." (Eurostat, 2010: 270). The findings presented here are from the third CVT survey in Europe, carried out in 2005.

2 This is not surprising as lifelong learning among those aged 25-64 is one indicator included in the IUS, which is behind the three innovation score groups. However, the measure by Eurostat (EC, 2013), used in the IUS, has a much shorter time-reference for participation (four weeks preceding the survey) than in PIAAC, the data used in this study (OECD, 2013a) (the last 12 months). The result, suggest that there is a strong consistence between these two different participation measures.

\section{REFERENCES}

Brown, S. K. (2012). What are older workers seeking? An AARP/SHRM Survey of 50+ Workers. Research and strategic analysis. AARP.

Cedefop. (2010a). The right skills for silver workers. An empirical analysis. Cedefop Research Paper 8. Luxembourg: Office for Official Publications of the European Communities.

Cedefop. (2010b). Employer-provided vocational training in Europe. Cedefop Research Paper 2. Luxembourg: Office for Official Publications of the European Communities.

Cedefop. (2011). Learning while working. Success stories on workplace learning in Europe. Luxembourg: Office for Official Publications of the European Communities.

Cedefop. (2012a). Learning and innovation in enterprises. Cedefop Research Paper 27. Luxembourg: Office for Official Publications of the European Communities.

Cedefop. (2012b). Future skills supply and demand in Europe. Forecast 2012. Cedefop Research Paper 26. Luxembourg: Office for Official Publications of the European Communities. 


\section{TIKKANEN}

Ellström, P.-E. (2011). Informal learning at work: Conditions, processes and logics. In M. Malloch, L. Cairns, K. Evans, \& B. N. O'Connor (Eds.), The Sage handbook of workplace learning (pp. 105119). London: Sage.

Ellström, P.-E. (1997). The many meanings of occupational competence and qualification. Journal of European Industrial Training, 21(6/7), 266-274.

Ellström, P.-E., \& Kock, H. (2008). Competence development in the workplace: Concepts, strategies and effects. Asia Pacific Education, 1, 5-20.

Eurobarometer. (2012). Active ageing. Special Eurobarometer 378. European Commission.

European Commission. (2007). Europe's demographic future: Facts and figures on challenges and opportunities. Luxembourg: Publications Office.

European Commission. (2010). Europe 2020 - A strategy for smart, sustainable and inclusive growth. Communication from the Commission, Brussels 3.3.2010 (COM(2010) 2020).

European Commission. (2011). Commission staff working paper: Action plan on adult learning: Achievements and results 2008-2010. EDUC40-SOC186-7169/11. Council of the European Union, Brussels.

European Commission. (2013). Education and training monitor 2013. Luxembourg: Publications Office.

European Commission. (2014a). European economic forecast: Spring 2014. European Economy 3/2014. Luxembourg: Publications Office.

European Commission. (2014b). Innovation Union scoreboard 2014. Luxembourg: Publications Office.

European Foundation. (2007). Fourth European working conditions survey. European Foundation for Improvement of Living Conditions. Luxembourg: Publications Office.

European Foundation. (2008). Working conditions of an ageing population. European Foundation for Improvement of Living Conditions. Luxembourg: Publications Office.

Eurostat. (2010). Europe in figures. Eurostat yearbook 2010. Luxembourg: Publications Office.

Findsen, B. (2006). Social institutions as sites of learning for older adults. Differential opportunities. Journal of Transformative Education, 4(1), 65-81.

Furunes, T., \& Mykletun, R. J. (2007). Why diversity management fails: Metaphor analyses unveil manager attitudes. International Journal of Hospitality Management, 26(4), 974-990.

Henseke, G., \& Tivig, T. (2007). Demographic change and industry-specific innovation patterns in Germany. Thuenen-Series of Applied Economic Theory, No. 72. Rostock: University of Rostock, Institute of Economics.

Hummert, M. L. (2011). Age stereotypes and aging. In K. W. Schaie \& S. L. Willis (Eds.), Handbook of the psychology of aging (7th ed., pp. 249-262). London: Academic Press/Elsevier.

ILO. (2014). World of work report. Geneve: ILO.

Krampe, R. Th., \& Charness, N. (2006). Ageing and expertise. In A. K. Ericsson, N. Charness, P. Feltovich, \& R. P. Hoffman (Eds.), Cambridge handbook on expertise and expert performance (pp. 723-742). Cambridge, UK: Cambridge University Press.

Lorenz, E. (2012). Labor market institutions, skills, and innovation style: a critique of the 'Varieties of Capitalism' perspective. In B. T. Asheim \& M. D. Parilli (Eds.), Interactive learning for innovation. A key driver for clusters and innovation systems (pp. 72-89). London: Palgrave Macmillan.

Lorenz, E., \& Lundvall, B.-Å. (2009). Measuring creativity in the European Union. In E. Villalba (Ed.), Can creativity be measured (pp. 157-181). Luxembourg: Publications Office of the European Union.

Lundvall, B.-Å., \& Lorenz, E. (2012). Innovation and competence building in the learning economy: implications for innovation policy. In B. T. Asheim \& M. D. Parilli (Eds.), Interactive learning for innovation. A key driver for clusters and innovation systems (pp. 33-71). London: Palgrave Macmillan.

Malloch,, M., Cairns, L., Evans, K., \& O’Connor, B. N. (Eds.). (2011). The Sage handbook of workplace learning. London: Sage. 
McEvoy, G. M., \& Cascio, W. F. (1989). Cumulative evidence of the relationship between employee age and job performance. Journal of Applied Psychology, 74, 11-17.

McDaniel, M. A., Pesta, B. J., \& Banks, G. C. (2012). Job performance and the ageing worker. In J. Hedge \& W. Borman (Eds.), The Oxford handbook of work and aging (pp. 280-297). New York: Oxford University Press.

McKinsey. (2012). The world at work; Jobs, pay and skills for 3.5 billion people. New York: McKinsey \& Company.

Naegele, G., \& Walker, A. (2006). Good practice in age management. European Foundation for Improvement of Living Conditions. Luxembourg: Publications Office.

Ng, T. W. H., \& Feldman, D. C. (2008). The relationship of age to ten dimensions of job performance. Journal of Applied Psychology, 93, 392-423.

OECD. (2006). Live longer, work longer. OECD Publishing.

OECD. (2010a). Science, technology and industry outlook 2010. Paris: OECD.

OECD. (2010b). Background questionnaire - Conceptual framework. Available at: http://www.oecd.org/site/piaac/Background\%20Questionnaire\%2015DEC10.pdf

OECD. (2011). Skills for innovation and research. Summary in English. Accessed 18.9.14 from: http://browse.oecdbookshop.org/oecd/pdfs/browseit/9211011E5.pdf

OECD. (2012a). Better skills, better jobs, better lives: A strategic approach to skills policies. OECD Publishing.

OECD (2012b). Innovation for development. A discussion of the issues and an overview of work of the OECD Directorate for Science, Technology and Industry. OECD Publishing.

OECD. (2013a). OECD skills outlook 2013. First results from the Survey of Adult Skills. OECD Publishing.

OECD. (2013b). The survey of adult skills. Reader's companion. OECD Publishing.

Posthuma R. A., \& Campion, M. A. (2009). Age-stereotypes in the workplace: Common stereotypes, moderators, and future research directions. Journal of Management, 35, 158-188.

Restrepo, T., \& Shuford, H. (2012). Workers compensation and the ageing workforce: Is 35 the new "older" worker? Research Brief, Oct. 2012. Boca Raton, FL: National Council on Compensation Insurance Inc (NCCI) .

Rix, S. E. (2005). Rethinking the role of older workers: promoting older workers employment in Europe and Japan. Issue Brief No 77. Washington, DC: AARP Public Policy Institute.

Rizzuto, T. E. (2011). Age and technology innovation in the workplace: Does work context matter? Computers in Human Behavior, 27(5), 1612-1620.

Shapiro, H., Lauritzen Keller, J. R., \& Irving, P. (2011). Emerging skills and competences - A transatlantic study. Copenhagen: DTI. Accessed 18/9/14 from: http://ec.europa.eu/education/moreinformation/doc/2011/skills_en.pdf

Skirbekk, V. (2003). Age and individual productivity: a literature survey. MPDIR Working Paper WP 2003-028. Rostock: Max Planck Institute for Demographic Research.

Sok, E. (2010). Record unemployment among older workers does not keep them out of the job market. Issues in labor statistics. Summary 10-04/March 2010. U.S. Bureau of Labor Statistics.

Statistical spotlight (2013). Ageing population: projections 2010-2060 for the EU27. European Parliamentary Research Service, 11/12/2013. Accessed 18/9/14 from: http://www.europarl.europa.eu/eplibrary/LSS-Ageing-population.pdf

Sturman, M. C. (2003). Searching for the inverted U-shaped relationship between time and performance: Meta-analyses of the experience/performance, tenure/performance, and age/performance relationships. Journal of Management, 29, 609-640.

Taylor, P., \& Walker, A. (1994). The ageing workforce: Employers' attitudes towards older people. Work, Employment \& Society, 8(4), 569-591.

Tikkanen, T. (2011a). Innovation capability and productivity: What has demographic change to do with it? In S. Jeschke, I. Isenhardt, F. Hees, \& S. Trantow (Eds.), Enabling innovation. innovative capability - German and international views (pp. 249-266). Berlin/Heidelberg: Springer. 


\section{TIKKANEN}

Tikkanen, T. (2011b). Editorial: From managing a problem to capitalizing on talent and experience of older workers. The International Journal of Human Resource Management, 22(6), 1215-1218.

Tikkanen, T. (1998). The age-participation relationship revised. Adult Education Quarterly, 49(1), 1527.

Tikkanen, T., \& Billett, S. (2014). Older professionals, learning and practice. In S. Billett, C. Harteis, \& H. Gruber (Eds.), The Springer international handbook of research in professional and practicebased learning. Berlin/Heidelberg/Dordrecht: Springer (in print).

UN. (2013). World population ageing 2013. New York: United Nations.

Waldman, D. A., \& Avolio, B. J. (1986). A meta-analysis of age differences in job performance. Journal of Applied Psychology, 71, 33-38.

Walker, A. (1997). Combating age barriers in employment: European research report. European Foundation. Luxembourg: Publications Office.

Warr, P. (1998). Age, competence and learning at work. In Å. Kilbom (Ed.), Ageing of the workforce. Key-note presentations and abstracts from a workshop in Brussels, March 23-24, 1998 (pp. 23-63). Solna: National Institute for Working Life [Arbetslivsinstitutet].

Warr, P. (1994). Ageing and job performance. In J. Snel \& R. Cremer (Eds.), Work and ageing. A European prospective (pp. 309-322). London: Taylor \& Francis.

Zacher, H., Heusner, S., Schmitz, M., \& Zwierzanska, M. M. (2010). Focus on opportunities as a mediator of the relationships between age, job complexity, and work performance. Journal of Vocational Behavior, 76(3), 374-386.

Zaidi, A. (2008). Features and challenges of population ageing: The European perspective. Policy Brief, March 1, 2008. Vienna: The European Centre for Social Welfare Policy Research.

\section{Tarja Tikkanen}

Stord/Haugesund University College

Norway 


\title{
10. LEARNING FOR DISADVANTAGED SENIORS
}

\author{
Issues of Outreach, Access Provision and Delivery
}

\section{INTRODUCTION}

In this chapter I look into some of the issues that refer to access, participation and provision of lifelong learning to disadvantaged older adults in a time of crisis. It is important at the outset to note that the term 'disadvantaged' is case specific; referring to those in a disadvantaged, needy or deprived state or position, and it is therefore approached within a specific context social, economic as well as cultural, educational or even medical. In the European social policy context (European Commission, 2007b: 87) the term 'disadvantaged' refers to a particular group of people with inadequate learning resources due to limited or restricted access to learning provision. In the older adults context it may also refer to those aged adults who are unemployed, dropouts or non-participants in learning, unskilled or low skilled, elderly with disabilities (mental or physical), seniors who have taken early retirement and third-age learners (Zarifis, 2013: 89). The main argument of this chapter is that because of the dire economic conditions in many parts of Europe -particularly in the south- older adults are not highly motivated to participate in education, whereas most of the time they are not well informed or they are unaware of existing educational opportunities that fit their needs. Based on relevant results from the European project PALADIN (2009), I also illustrate how a number of older adults with low self-efficacy ${ }^{1}$ may be unable to participate in learning because they do not consider it as important, or because they think it is irrelevant to their development (Bettio et al., 2012). I conclude that it is of critical importance to address these conditions for assessing how disadvantaged older adults in Europe may be motivated to participate in educational activities, but also for providing education that directly targets disadvantaged older adults' needs.

\section{DEMOGRAPHIC TRANSFORMATIONS AND ECONOMIC CRISIS - A CONUNDRUM FOR EUROPE}

The aged population in Europe is increasing rapidly. Why this is happening is definitely an issue of demographic change that will have broad consequences for European societies. The numbers according to Eurostat are indicative of a steadily growing condition particularly for those aged 65 and over (Table 10.1). 
Table 10.1. Proportion of population aged 65 and over (\% of total population).

\begin{tabular}{|c|c|c|c|c|c|c|c|c|c|c|}
\hline GEO/TIME & 2003 & 2004 & 2005 & 2006 & 2007 & 2008 & 2009 & 2010 & 2011 & 2012 \\
\hline $\begin{array}{l}\text { EU }(27 \\
\text { countries) }\end{array}$ & 16.2 & 16.4 & 16.6 & 16.8 & 16.9 & 17.1 & 17.2 & 17.4 & 17.5 & 17.8 \\
\hline Euro area (17 & & & & & & & & & & \\
\hline countries) & 16.9 & 17.1 & 17.4 & 17.6 & 17.8 & 17.9 & 18.1 & 18.3 & 18.4 & 18.7 \\
\hline Belgium & 17 & 17.1 & 17.2 & 17.2 & 17.1 & 17.1 & 17.1 & 17.2 & 17.1 & 17.3 \\
\hline Bulgaria & 17 & 17.1 & 17.1 & 17.2 & 17.3 & 17.3 & 17.4 & 17.5 & 18.5 & 18.8 \\
\hline Czech Republic & 13.9 & 13.9 & 14 & 14.2 & 14.4 & 14.6 & 14.9 & 15.2 & 15.6 & 16.2 \\
\hline Denmark & 14.8 & 14.9 & 15 & 15.2 & 15.3 & 15.6 & 15.9 & 16.3 & 16.8 & 17.3 \\
\hline Germany & 17.5 & 18 & 18.6 & 19.3 & 19.8 & 20.1 & 20.4 & 20.7 & 20.6 & 20.6 \\
\hline Estonia & 15.9 & 16.2 & 16.5 & 16.7 & 17.1 & 17.2 & 17.1 & 17.1 & 17 & 17.2 \\
\hline Ireland & 11.1 & 11.1 & 11.1 & 11 & 10.9 & 10.9 & 11 & 11.3 & 11.5 & 11.9 \\
\hline Greece & 17.5 & 17.8 & 18.1 & 18.5 & 18.6 & 18.6 & 18.7 & 18.9 & 19.3 & 19.7 \\
\hline Spain & 16.9 & 16.9 & 16.8 & 16.7 & 16.7 & 16.6 & 16.6 & 16.8 & 17.1 & 17.4 \\
\hline France & 16.1 & 16.2 & 16.3 & 16.4 & 16.3 & 16.4 & 16.5 & 16.6 & 16.7 & 17.1 \\
\hline Croatia & 16.2 & 16.4 & 16.7 & 16.9 & 17 & 17.2 & 17.3 & 17.3 & 17.2 & 17.3 \\
\hline Italy & 19 & 19.2 & 19.5 & 19.7 & 19.9 & 20 & 20.1 & 20.2 & 20.3 & 20.6 \\
\hline Cyprus & 11.8 & 11.9 & 11.9 & 12 & 12.3 & 12.5 & 12.7 & 12.5 & 12.7 & 12.8 \\
\hline Latvia & 15.9 & 16.2 & 16.5 & 16.8 & 17.1 & 17.2 & 17.3 & 17.4 & 18.4 & 18.6 \\
\hline Lithuania & 14.7 & 15 & 15.1 & 15.3 & 15.6 & 15.8 & 16 & 16.1 & 17.9 & 18.1 \\
\hline Luxembourg & 14 & 14 & 14.1 & 14.1 & 14 & 14 & 14 & 14 & 13.9 & 14 \\
\hline Hungary & 15.4 & 15.5 & 15.6 & 15.8 & 15.9 & 16.2 & 16.4 & 16.6 & 16.7 & 16.9 \\
\hline Malta & 12.8 & 13 & 13.3 & 13.7 & 13.8 & 13.8 & 14.1 & 14.8 & 15.7 & 16.5 \\
\hline Netherlands & 13.7 & 13.8 & 14 & 14.3 & 14.5 & 14.7 & 15 & 15.3 & 15.6 & 16.2 \\
\hline Austria & 15.4 & 15.5 & 15.9 & 16.4 & 16.9 & 17.1 & 17.4 & 17.6 & 17.6 & 17.8 \\
\hline Poland & 12.8 & 13 & 13.1 & 13.3 & 13.4 & 13.5 & 13.5 & 13.5 & 13.5 & 13.8 \\
\hline Portugal & 16.7 & 16.8 & 17 & 17.1 & 17.3 & 17.4 & 17.6 & 17.9 & 19.1 & 19.4 \\
\hline Romania & 14.2 & 14.4 & 14.7 & 14.8 & 14.9 & 14.9 & 14.9 & 14.9 & 14.9 & 15 \\
\hline Slovenia & 14.8 & 15 & 15.3 & 15.6 & 15.9 & 16.3 & 16.4 & 16.5 & 16.5 & 16.8 \\
\hline Slova & 11.5 & 11.5 & 11.6 & 11.7 & 11.9 & 12 & 12.1 & 12.3 & 12.6 & 12.8 \\
\hline Finland & 15.3 & 15.6 & 15.9 & 16 & 16.5 & 16.5 & 16.7 & 17 & 17.5 & 18.1 \\
\hline Sweden & 17.2 & 17.2 & 17.2 & 17.3 & 17.4 & 17.5 & 17.8 & 18.1 & 18.5 & 18.8 \\
\hline United $\mathrm{K}$ & 15.9 & 16 & 16 & 16 & 16 & 16.1 & 16.3 & 16.5 & 16.6 & 16.9 \\
\hline Iceland & 11.7 & 11.8 & 11.8 & 11.7 & 11.6 & 11.5 & 11.6 & 12 & 12.3 & 12.6 \\
\hline Liechtenstein & 10.8 & 10.8 & 11.1 & 11.6 & 11.9 & 12.4 & 12.9 & 13.5 & 13.9 & 14.4 \\
\hline Norway & 14.8 & 14.7 & 14.7 & 14.7 & 14.6 & 14.6 & 14.7 & 14.9 & 15.1 & 15.4 \\
\hline Switzerland & 15.6 & 15.7 & 15.8 & 16 & 16.2 & 16.4 & 16.6 & 16.8 & 16.9 & 17.2 \\
\hline Turkey & 5.6 & 5.7 & 5.8 & 5.9 & & 7.1 & 6.8 & & 7.2 & 1.3 \\
\hline
\end{tabular}

Source: Eurostat; Last update: 30.10.2013;

Date of extraction: 28 Dec 2013 02:20:37 MET;

Hyperlink to the table:

http://epp.eurostat.ec.europa.eu/tgm/table.do?tab=table\&init=1\&plugin=1\& language $=$ en $\&$ pode $=\operatorname{tps} 00028$

Europe is faced with a real conundrum as the increasing share of the elderly population may result in a raised demand for care, particularly if the health status of the elderly remains unchanged or even be worsened as it already have happened in many EU members states today due to the socio-economic crisis. As Table 10.1 shows, countries like Germany, Malta, Finland, Greece and Portugal have an over $3 \%$ increase of population aged over 65 in a decade while the average for all EU member states is $2 \%$ rise for the same period. The highest increase is reported in 
Germany (4\%), while the lowest is reported in Belgium $(0.4 \%)$. This overall increasing trend raises questions on the level of readiness of many member states that are hit by the recent economic crisis - particularly in the southern part of Europe - to deal with social welfare and protection of older adults. Furthermore the risk of poverty, especially among older adults in European countries that have been hit by the economic crisis, makes a difficult case for many member states.

Despite a relevant decrease in the last few years risk-of-poverty among older adults is still considerably high (Table 10.2), although there is a lack of precision

Table 10.2. At-risk-of-poverty for aged 65 and over.

\begin{tabular}{|c|c|c|c|c|c|c|c|c|c|c|}
\hline GEO/TIME & 2003 & 2004 & 2005 & 2006 & 2007 & 2008 & 2009 & 2010 & 2011 & 2012 \\
\hline European Union & & & & & & & & & & \\
\hline $\begin{array}{l}\text { (28 countries) } \\
\text { Euro area }(17\end{array}$ & & $:$ & : & : & ${ }^{\circ}$ & $:$ & : & 16.0 & 15.9 & 14.5 \\
\hline countries) & & : & 18.8 & 18.9 & 18.2 & 18.9 & 17.8 & 15.9 & 15.8 & 14.4 \\
\hline Belgium & 17 & $:$ & & & & & & & & \\
\hline Bulgaria & 19 & 19 & 19.8 & 19.6 & 18.6 & 19.1 & 17.8 & 16.1 & 16.2 & 14.5 \\
\hline Czech Republic & & 20.5 & 14.6 & 15.6 & 16.4 & 18.0 & 17.9 & 14.5 & 13.6 & 14.1 \\
\hline Denmark & 8 & . & & & & & & & & \\
\hline Germany & & $:$ & 19.1 & 18.6 & 19.0 & 17.9 & 17.0 & 15.2 & 15.1 & 14.1 \\
\hline Estonia & 22.0 & 20.9 & 21.4 & 23.2 & 23.0 & 21.2 & 21.6 & 19.4 & 20.2 & 17.6 \\
\hline Ireland & 14 & 16 & 18 & 19.9 & 23.9 & 33.8 & 39.3 & 32.2 & 31.2 & 28.2 \\
\hline Greece & & $:$ & 5.3 & 5.9 & 5.5 & 7.4 & 7.2 & 6.8 & 6.6 & 6.0 \\
\hline Spain & 20.9 & 17.0 & 17.6 & 17.4 & 17.7 & 18.1 & 20.1 & 17.7 & 16.0 & 14.1 \\
\hline France & & . & 13.4 & 12.5 & 16.2 & 14.9 & 15.0 & 14.1 & 14.2 & 15.0 \\
\hline Croatia & 17 & 20.5 & 20.3 & 25.1 & 33.2 & 39.0 & 33.9 & 15.1 & 13.1 & 17.2 \\
\hline Italy & 39.5 & 38.0 & 32.8 & 26.9 & 28.3 & 21.1 & 16.2 & 9.9 & 11.0 & \\
\hline Cyprus & 29.4 & 28.2 & 27.9 & 25.6 & 22.9 & 22.3 & 21.4 & 21.3 & 23.6 & 17.2 \\
\hline Latvia & 28 & 29.8 & 28.8 & 29.3 & 26.1 & 26.9 & 23.1 & 20.5 & 19.5 & 14.8 \\
\hline Lithuania & 11 & 15.3 & 16.4 & 16.1 & 13.1 & 11.7 & 11.9 & 10.6 & 9.7 & 9.4 \\
\hline Luxembourg & 31 & 32 & 29 & 31 & 30 & 31.2 & 31.3 & 29.1 & 28.5 & 26.5 \\
\hline Hungary & & 21.0 & 22.6 & 21.7 & 21.9 & 20.9 & 19.6 & 16.6 & 17.0 & 16.3 \\
\hline Malta & 52 & 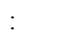 & 50.3 & 51.9 & 50.6 & 46.3 & 46.4 & 39.9 & 35.5 & 29.3 \\
\hline Netherlands & & : & 21.2 & 29.8 & 33.3 & 51.2 & 47.5 & 18.8 & 8.9 & 14.0 \\
\hline Austria & & : & 17.0 & 22.0 & 29.8 & 29.5 & 25.2 & 10.2 & 9.7 & 18.7 \\
\hline Poland & 10.3 & 8.2 & 7.8 & 7.9 & 7.2 & 5.4 & 6.0 & 5.9 & 4.7 & 6.1 \\
\hline Portugal & 10 & : & 6.5 & 9.4 & 6.1 & 4.3 & 4.6 & 4.1 & 4.5 & 6.0 \\
\hline Romania & & 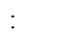 & 23.4 & 24.2 & 20.7 & 24.7 & 20.9 & 18.0 & 18.1 & 17.4 \\
\hline Slovenia & 7 & r. & 5.4 & 5.8 & 9.5 & 9.4 & 7.7 & 5.9 & 6.5 & 5.5 \\
\hline Slovakia & 15.9 & 17.0 & 14.3 & 16.2 & 14.0 & 15.0 & 15.1 & 15.2 & 16.0 & 15.1 \\
\hline Finland & & $:$ & 7.3 & 7.8 & 7.8 & 11.7 & 14.4 & 14.2 & 14.7 & 14.0 \\
\hline Sweden & & 28.9 & 27.6 & 26.1 & 25.5 & 22.3 & 20.1 & 21.0 & 20.0 & 17.4 \\
\hline United Kingdom & 20 & 17 & & & 30.6 & 26.0 & 21.0 & 16.7 & 14.1 & 15.4 \\
\hline Iceland & 19 & : & 20.3 & 19.9 & 19.4 & 21.3 & 20.0 & 20.2 & 20.9 & 19.6 \\
\hline Norway & & : & 7.1 & 8.5 & 9.6 & 9.9 & 10.8 & 7.7 & 6.3 & 7.8 \\
\hline Switzerland & 17 & 16.7 & 18.7 & 21.8 & 21.6 & 22.5 & 22.1 & 18.3 & 18.9 & 18.4 \\
\hline Turkey & & 14.0 & 10.1 & 11.3 & 9.9 & 15.0 & 17.7 & 15.5 & 18.2 & 17.5 \\
\hline
\end{tabular}

Source: Eurostat; Last update: 17.12.2013

Date of extraction: 28 Dec 2013 02:28:14 MET

Hyperlink to the table: http://appsso.eurostat.ec.europa.eu/nui/submitViewTableAction.do 
and confusion when interpreting figures on poverty in old age, as figures hide important differentials between countries, but also within the older population at national level (Zaidi, 2010).

Important differences are also hidden when one looks at sub-groups of older people such as older women, single older persons, and older people in urban and rural areas or older migrants or ethnic minorities. Older women and the very old tend to face much higher poverty risk rate than the average figure in most of the countries reported in Table 10.2. Therefore, any interpretation of poverty in old age must also be age and gender proofed, given the fact that overall older population is not homogenous and very significant differences in poverty risk exist among its subgroups ('Age Platform Europe', 2012). The ageing phenomenon in Europe along with the risk-of-poverty depicts an ominous trend that is not easily reversible as long as relevant policies in Europe do not address to the real needs of the older population and in particular of those older adults who are poor and disadvantaged.

\section{PROMOTING ACCESS AND PARTICIPATION IN EDUCATION FOR DISADVANTAGED SENIORS - ISSUES TO CONSIDER IN A TIME OF SOCIO-ECONOMIC CRISIS}

One of the issues that will soon need to be addressed by European policy-makers is that of access and participation of older adults in education, and specifically of the disadvantaged ones. Access and participation in educational opportunities for disadvantaged older adults must however be approached from a different angle than the one used to justify engagement to education for older adults in general, because disadvantaged older adults consist a social sub-group within the older adults' population with specific learning needs. The research in Europe so far shows that older people in general are involved in learning for a variety of reasons and their motivations for engaging in education are diverse. Based on the results of the PALADIN research project ${ }^{2}$ (2009) it is evident that some seniors are learning for pleasure or as a hobby or interest in retirement, some are learning to enhance or change their careers, and some want to fulfill lifelong ambitions and seize the opportunities that they were denied earlier in life. PALADIN also observed the diversity in the types of learning activities in which disadvantaged older adults engage, and their motivation for engaging in them. In this respect accessing certain educational programmes and ensuring participation for disadvantaged seniors, may only be based on their readiness for learning and self-efficacy. It is therefore paramount to look at the broader picture as well as its segments in order to find ways to promote older adults' participation in education and learning.

Based on PALADIN results and Formosa's approach to critical gerogogy (2002: 77), most learning activities that are addressed to older adults in Europe today do not meet the needs of all older participants, but mostly those from an élite and middle class or bourgeois background. As a result of its financial support for such programmes, many European countries succeeded in camouflaging the enactment of ageist policies as these are prescribed by the European Commission. Additional commercial entrepreneurs benefited by having access to a promising 
pool of financially secure people. At the same time, middle class older people found the programmes highly appropriate to their lifelong interests and dispositions, as well as a means to recoup lost status resulting from mandatory retirement. This however cannot be easily claimed today for those older adults who are in disadvantage because of the crisis. Many of those older adults who are now considered as disadvantaged were middle class before the crisis and therefore considered as privileged due to their secure state pension schemes and welfare protection systems in their countries. Today however much of what is considered accessible learning provision, especially in southern European countries such as Greece, Cyprus, Spain and Italy, is far from what disadvantaged older adults need in this time of crisis, hence empowerment and orientation for decision-making and solidarity.

In the literature there is evidence that older adults, particularly older women, often engage in education and learning for pleasure or self-esteem rather than for economic reasons as one would expect from younger adults. This may lead educational providers and policy-makers in Europe to question why they should fund educational initiatives for older adults if they do not yield economic returns through the workforce. Besides the immediate literary evidence, there are also a number of moral arguments to support access and participation for older adults in disadvantage. According to Bunyan and Jordan (2005) education, like health, is a public good and educational distribution must be to everyone's advantage and accessible to all. Education can improve quality of life for older adults, many of whom have been disadvantaged through no fault of their own. This is because in principle education is concerned with combating social exclusion and providing the means to actively participate in the cultural life of the community. Furthermore some authors acknowledge that as people age, they become increasingly marginalised by society in economic, social, political and cultural terms.

Theoretical approaches and research evidence call for major changes in European societies and not only in terms of participation in educational provision The real challenge for European policy-making is to provide opportunities that will enhance participation of disadvantaged older adults at all levels of society. For example, active citizenship must be linked to the ability to accessing information. According to Schmidt-Hertha and Strobel-Dümer (2014) there are many older adults in Europe who are not familiar with accessing modern media of communication such as the internet. Older adults must have equal rights and access to education, with positive measures put in place to ensure equality of provision but also for the sake of enjoyment.

Besides the theoretical debate the real picture on access and participation to learning for older adults in Europe is dire (Table 10.3). Needless to say that a high proportion of people at the age group 50-74 is largely invisible to EU policy makers (Formosa, 2012), but not statistically irrelevant, as many senior citizens in Europe, either participate in informal learning activities, or they simply do not participate in any education or learning activity at all, due to lack of access or other factors that are as yet unidentified. This is more evident in countries like Hungary, 
Table 10.3. Participation in education and training for older adults between 50-74 in all ISCED levels

\begin{tabular}{|c|c|c|c|c|c|c|c|c|c|c|}
\hline GEO/TIME & 2003 & 2004 & 2005 & 2006 & 2007 & 2008 & 2009 & 2010 & 2011 & 2012 \\
\hline $\begin{array}{c}\text { European Union } \\
(28 \text { countries })\end{array}$ & 3.4 & 3.8 & 4.1 & 4.2 & 4.3 & 4.5 & 4.5 & 4.3 & 4.2 & 4.4 \\
\hline Belgium & 2.8 & 3.7 & 3.8 & 3.4 & 3.6 & 3.2 & 3.2 & 3.7 & 3.6 & 3.4 \\
\hline Bulgaria & & $:$ & & 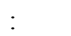 & & & & $:$ & : & \\
\hline Czech Republic & 1.8 & 2.1 & 1.9 & 2.2 & 2.3 & 3.2 & 2.7 & 3.0 & 5.4 & 5.1 \\
\hline Denmark & 15.1 & 16.3 & 18.3 & 21.7 & 21.9 & 22.9 & 24.6 & 25.3 & 23.8 & 23.9 \\
\hline Germany & 1.7 & 2.3 & 2.4 & 2.4 & 2.6 & 2.8 & 2.7 & 2.7 & 2.6 & 2.7 \\
\hline Estonia & 1.8 & 1.8 & 0.9 & 2.0 & 2.1 & 4.0 & 3.8 & 4.4 & 4.6 & 4.9 \\
\hline Ireland & 2.9 & 2.8 & 3.6 & 3.6 & 3.7 & 3.5 & 3.0 & 3.2 & 3.1 & 3.4 \\
\hline Greece & 0.4 & 0.2 & 0.2 & 0.2 & 0.2 & 0.4 & 0.6 & 0.6 & 0.4 & 0.6 \\
\hline Spain & 1.0 & 1.1 & 4.4 & 4.6 & 4.8 & 4.9 & 5.2 & 5.3 & 5.2 & 5.4 \\
\hline France & 2.3 & 1.9 & 1.9 & 2.3 & 2.4 & 2.5 & 2.3 & 2.1 & 2.4 & 2.5 \\
\hline Croatia & : & $:$ & : & 0.4 & 0.3 & 0.2 & 0.2 & 0.1 & 0.2 & 0.2 \\
\hline Italy & 1.1 & 1.8 & 1.6 & 1.8 & 2.1 & 2.2 & 2.1 & 2.4 & 2.2 & 2.8 \\
\hline Cyprus & 2.4 & 3.4 & 2.1 & 3.0 & 3.6 & 3.7 & 3.0 & 3.1 & 3.6 & 3.0 \\
\hline Latvia & 2.2 & 2.7 & 2.3 & 1.9 & 2.3 & 1.9 & 1.5 & 1.6 & 1.8 & 3.1 \\
\hline Lithuania & 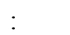 & 1.6 & 1.6 & 1.3 & 1.4 & 0.9 & 0.7 & 0.9 & 2.0 & 2.1 \\
\hline Luxembourg & 2.1 & 3.9 & 3.0 & 2.8 & 2.7 & 3.3 & 5.6 & 5.7 & 5.7 & 6.0 \\
\hline Hungary & 0.8 & 0.6 & 0.5 & 0.5 & 0.5 & 0.4 & 0.3 & 0.4 & 0.4 & 0.5 \\
\hline Malta & 1.7 & 1.8 & 2.4 & 2.3 & 2.2 & 3.1 & 3.1 & 2.8 & 3.1 & 2.9 \\
\hline Netherlands & 7.2 & 7.4 & 7.4 & 7.4 & 8.0 & 8.5 & 8.4 & 8.5 & 8.4 & 8.5 \\
\hline Austria & 2.8 & 5.2 & 5.9 & 6.3 & 6.2 & 5.9 & 6.7 & 6.8 & 6.5 & 6.9 \\
\hline Poland & 0.6 & 1.2 & 1.1 & 1.1 & 1.1 & 1.1 & 1.1 & 1.2 & 0.9 & 0.9 \\
\hline Portugal & 0.2 & 0.6 & 0.6 & 0.7 & 1.0 & 1.1 & 1.3 & 1.3 & 4.5 & 4.1 \\
\hline Romania & & . & $:$ & $:$ & $:$ & $:$ & $:$ & . & 0.2 & 0.2 \\
\hline Slovenia & 3.7 & 5.7 & 5.6 & 5.6 & 5.4 & 5.3 & 6.1 & 6.7 & 6.9 & 6.5 \\
\hline Slovakia & 1.5 & 1.8 & 2.0 & 1.6 & 1.7 & 1.0 & 0.7 & 0.8 & 1.3 & 1.0 \\
\hline Finland & 13.3 & 13.4 & 13.0 & 13.3 & 13.7 & 13.3 & 13.0 & 13.3 & 13.6 & 14.3 \\
\hline Sweden & & & 11.4 & 12.3 & 12.2 & 14.8 & 14.9 & 16.4 & 17.0 & 18.2 \\
\hline United Kingdom & 20.6 & 22.3 & 21.4 & 20.7 & 11.9 & 12.3 & 12.3 & 11.7 & 9.6 & 10.0 \\
\hline Iceland & 18.5 & 14.4 & 15.7 & 17.8 & 16.9 & 15.4 & 15.0 & 16.0 & 16.7 & 17.8 \\
\hline Norway & 9.7 & 10.3 & 10.3 & 11.0 & 10.2 & 11.0 & 10.2 & 10.4 & 10.4 & 11.4 \\
\hline Switzerland & 16.1 & 18.3 & 17.3 & 14.7 & 17.8 & 19.2 & 13.0 & 21.4 & 20.8 & 20.9 \\
\hline Turkey & & & & 0.1 & 0.1 & 0.2 & 0.2 & 0.2 & 0.3 & 0.3 \\
\hline
\end{tabular}

Source: Eurostat; Last update: 5.12.2013;

Date of extraction: 28 Dec 2013 01:16:22 MET:

Hyperlink to the table:

http://appsso.eurostat.ec.europa.eu/nui/submitViewTableAction.do;jsessionid=9ea7d07e30e 2e41f1e9300ac49608987b5acd1a9b957.e34OaN8Pc3mMc40Lc3aMaNyTb3mSe0

Romania, Greece or Croatia where the participation rate in educational training is particularly low.

Statistics however mean little when taken in isolation from issues of economic status and social policy. Considering the current socio-economic crisis we need to relate existing statistical evidence on participation to relevant qualitative evidence on levels and reasons of poverty, provision of social welfare or lack of it as well as micro and meso-level indications possible diversities and heterogeneities among the older adult population. The bald presentation of statistical facts disguises the 
diversity and heterogeneity of older populations in different countries and stands to be accused of perpetuating a 'them and us' mentality - as though older people were somehow 'the other'. In this way, older people come to be seen as a different species from the rest of the population leading to a lack of recognition that ageing is something which everyone experiences (Withnall, 2000).

This essentially relates to a set of what I call 'strategy barriers' that are preventing older adults' access to education and learning in its various forms as EU policy making cannot stress much the need to expand lifelong learning in terms of the competitive advantage, that is, increasingly dependent on investment in human capital and on benchmarked knowledge and competences becoming a powerful engine for economic growth. As Formosa puts it:

The EU vision on late-life learning never escapes the greater project to render Europe more competitive in the face of fierce competition from the transitional and multinational corporations' ability to reap the advantages of economies of scale through expansion of international capital mobility. Human experience is surrendered to the controls of the market, so that any notion of meaning detached from "work" and not defined according to capitalist logic simply disappears. (Formosa, 2012: 393-394)

The current economic crisis can be an important starting point to explore the obstacles that disadvantaged older people in particular are facing with accessing and participating to educational and learning activities. Existing strategy barriers can be strong impediments - hence deprive people of accessing learning activities - and they need to be identified in terms of the group of older people under investigation.

Current European emphasis on lifelong learning as a medium for economic growth suggests that the time is ripe to launch a new debate about principles and morals in the provision of educational opportunities for older people in our continent, as the ageing of European populations poses a challenge to policy-liked notions of lifelong learning. As Glendenning (2001) points out, there are two major assumptions in the policy and much of the literature relating to older adults that must be challenged: firstly, that all people over a given arbitrary age (60 or 65 for instance) can be lumped together and dealt with as though they were a homogeneous group; secondly, the assumption that the elderly, as a group, are in some specific way disadvantaged educationally because of the one factor of their age. If these two assumptions are challenged then the question as to whether provision for disadvantaged older adults should or should not be separated from the provision for the general older adult population becomes easier to resolve. This is because older adults can also be separated into different target groups, in exactly the same way as with the adult population at large. It is in this respect that we need to make a clear distinction among those seniors who make that conscious decision to access and participate in learning activities and those who do not, in order to identify the ones benefiting from learning and the ones who do not and therefore may be considered disadvantaged. 


\section{EPILOGUE}

Despite certain positive aspects of EU policy's strong commitment to portray aging in a positive light and especially to highlight the potential of an aging population, the current economic crisis that negatively affects older adults in financial terms but also in accessing needed health or social services, reshuffles the current debate on lifelong learning for older adults. According to 'Age Platform Europe' (2012: 7) many older adults are confronted unexpectedly with new forms of vulnerability, are affected by deep helplessness or distress, withdrawing gradually from family and social life, that can also be translated to low participation in educational or learning activities. Due to the crisis and the overall gloomy socio-economic climate in many southern European countries in particular - more older people are withdrawing from active social participation and show symptoms of an increased disinterest in political and social life resulting in feelings of further isolation from the mainstream society. However and despite the negative repercussions of the economic crisis in other social groups, it is older adults' well-being and dignity which are more at stake as many of them are care-dependent or socially disadvantaged.

Relevant policy initiatives in Europe (European Commission, 2006, 2007a, 2007b) have already addressed these issues albeit with no direct and reliable response that has a positive impact on older adults' welfare (Formosa, 2012). What we essentially need in Europe in order to respond to these challenges besides a broad engagement to solidarity among European citizens of all ages, is to strengthen access and participation to learning to those disadvantaged older adults who are most in need in this time of crisis. This can be achieved through direct support of disadvantaged older adults at micro-level, with immediate and on-going diagnosis of learning and social needs that will further address the generation of relevant supportive policies at meso-level (a bottom-up approach). This may be proven crucial especially for those disadvantaged older adults who rarely participate or do not participate at all in education and learning to educational and learning. In order to do this we first need to understand the basis on which disadvantaged older adults make choices about learning, to identify what constitutes a successful learning experience for them and to assess what learning means in the context of their own lives (day-to-day living as well as a broader appreciation of life itself). When older adults are in situations that call for support, they need quality responses. These responses should be developed with the perspective of the recognition of the right to full citizenship, equal opportunities, and participation in economic, social and cultural development. As conscious Europeans, we need to understand that despite the accumulation thesis that older people with higher levels of education reveal a greater agency and a greater healthy aging (Oliveira et al., 2011, 2013), the development and testing of an all inclusive conceptual model of the reasons for participation, pathways through and outcomes from undertaking different types of learning activity by older adults during periods of social and/or economic crises, might enlighten our knowledge of how learning and participation to learning and education operates for this age group. 


\section{NOTES}

1 According to Bandura (1994) perceived self-efficacy is defined as people's beliefs about their capabilities to produce designated levels of performance that exercise influence over events that affect their lives. Self-efficacy beliefs determine how people feel, think, motivate themselves and behave. Such beliefs produce these diverse effects through four major processes. They include cognitive, motivational, affective and selection processes.

2 Many resources have been produced for the elderly (see http://projectpaladin.eu/) and it is worth noting the Self-efficacy for self-directed learning scales (in five areas: health, activity, citizenship, education and finances) and the Self-efficacy and worthy old age memorandum.

\section{REFERENCES}

Age Platform Europe (2012). Older people also suffer because of the crisis. Report released in November 2012. Accessed 18 September 2014 from: www.50plus.gr/wp-content/uploads/2012/12/ olderpeoplealsosufferbcofthecrisis-en.pdf

Bandura, A. (1994). Self-efficacy. In V. S. Ramachaudran (Ed.), Encyclopedia of human behavior (Vol. 4, pp. 71-81). New York: Academic Press.

Bettio, F., Corsi, M., D’Ippoliti, C., Lyberaki, A., Samek Lodovici, M., \& Verashchagina, A. (2012). The impact of the economic crisis on the situation of women and men and on gender equality policies. Synthesis Report of the Expert Group on Gender and Employment. Brussels: European Commission.

Bunyan, K., \& Jordan, A. (2005). Too late for the learning: Lessons from older learners. Research in Post-Compulsory Education, 10(2), 267-281.

European Commission. (2006). The demographic future of Europe - From challenge to opportunity. Commission Communication (COM (2006) 571). Brussels: European Commission. Accessed 18/9/14 from: http://ec.europa.eu/employment_social/news/2006/oct/demography_en.pdf

European Commission. (2007a). Demography report 2007 - Europe's demographic future: Facts and figures. SEC (2007) 638. Brussels: European Commission. Accessed 18/9/14 from: http://ec.europa.eu/employment_social/spsi/docs/social_situation/sec_2007_638_en.pdf

European Commission. (2007b). Promoting solidarity between the generations. Brussels: European Commission. Accessed 18 September 2014 from: http://eurlex.europa.eu/LexUriServ/ LexUriServ.do?uri=COM:2007:0244:FIN:EN:PDF

European Commission (2008). Demography report 2008: Meeting social needs in an ageing society. SEC (2008) 2911. Brussels: European Commission. Accessed 18/9/14 from: http://ec.europa.eu/social/main.jsp?langId=de\&catId=89\&newsId=419

Formosa, M. (2002). Critical gerogogy: Developing practical possibilities for critical educational gerontology. Education and Ageing, 17(1), 73-85.

Formosa, M. (2012). European Union policy on older adult learning: A critical commentary. Journal of Aging \& Social Policy, 24(4), 384-399.

Glendenning, F. (2001). Education for older adults. International Journal of Lifelong Education, 20(1/2), 63-70.

Oliveira, A. L., Coimbra Vieira, M., Pedroso De Lima, M., Alcoforado, L., Mairos Ferreira, S., \& Ferreira, J. A. (Eds). (2013). Promoting conscious and active learning and aging: How to face current and future challenges? Coimbra: Imprensa da Universidade de Coimbra.

Oliveira, A. L., Vieira, C., Lima, M. P., Nogueira, S., Alcoforado, L., Ferreira, J. A., \& Zarifis, G. (2011). Developing instruments to improve learning and development of disadvantage seniors in Europe: The PALADIN Project. In Proceedings of the International Conference The Future of Education (Vol. 1, pp. 268-274). Florence: Simonelli Editore. 


\section{ZARIFIS}

PALADIN. (2009). Promoting active ageing and learning of disadvantage seniors. Accessed 18 September 2014 from: http://projectpaladin.eu

Schmidt-Hertha, B., \& Strobel-Dümer, C. (2014). Computer literacy among the generations: How can older adults participate in digital society? In G. K. Zarifis, \& M. N. Gravani (Eds.), Challenging the 'European Area of Lifelong Learning'. A critical response (pp. 31-40). Springer: Dordrecht.

Withnall, A. (2000). Reflection on lifelong learning and the third age. In J. Field \& M. Leicester (Eds.), Lifelong learning across the lifespan (pp. 289-299). London: Falmer Press.

Zaidi, A. (2010). Poverty risks for older people in EU countries. Vienna: European Centre for Social Policy and Research.

Zarifis G. K. (2013). Who is a disadvantaged senior in Europe? Main identifiers for assessing efficacy for self-directed learning of the aged and at-risk. In A. Lima Oliveira, C. M. Coimbra Vieira, M. Pedroso De Lima, L. Alcoforado, S. Mairos Ferreira, \& J. A. Ferreira (Eds.), Promoting conscious and active learning and aging: how to face current and future challenges? (pp. 87-112). Coimbra: Imprensa da Universidade de Coimbra.

Georgios K. Zarifis

Faculty of Philosophy, School of Philosophy and Education

Aristotle University of Thessaloniki

Greece 


\title{
11. VOLUNTARY WORK AS THE SENIORS' SPACE FOR LEARNING
}

\author{
INTRODUCTION
}

Voluntary work, in spite of its growing popularity, is not a phenomenon coming up from postmodernity. The beginning of volunteering can be seen after the First World War. The related terms are philanthropy, self-help groups, public benefit organizations, non-governmental organizations, non-profit organizations as well as the third sector. As it appears from Public Opinion Research Centre, $73 \%$ of volunteers are young people (Komunikat z badań, 2011).

Involvement in voluntary work gives young people a lot of benefits such as the possibility to get experience, undergoing training, striking up an acquaintance in the professional area, travelling and, as research shows, it is trendy (Komunikat $\mathrm{z}$ badań, 2011). Whereas, for seniors to get involved in voluntary work, often need external motivation and acceptance. The Survey of Health, Ageing and Retirement in Europe (SHARE project) shows that in Poland less than $4 \%$ of people who are 50 take up volunteering (Seniorze jesteś potrzebny, 2012).

Involvement in voluntary work of people in late adulthood either is not noticeable or seniors' volunteering is not appropriately named and promoted. Retired people have more free time than young ones. They are ready and willing to be active citizens and volunteers, however, they are often perceived as passive, useless people 'taking youngsters' place'. Therefore, the question arises whether voluntary work is a place for seniors. Is it their space of learning? The attempt to answer the questions mentioned above has been taken in this article.

Understanding the period of ageing and looking at it from the perspective of development, transformation and learning still requires, in my opinion, a lot of research. Seniors' voluntary service is one of the areas which is, to a small extent, recognized in gerontology.

The multi-layered structure of the article is an invitation for a reader, in the first part, to the reflection on learning of ageing on lifelong perspective and some forms of voluntary work in the context of age. Whereas, the second part is an empirical illustration of seniors' volunteering in the context of learning and represents a contribution to the further research.

\section{THE ROLE OF VOLUNTEERING IN THE CONTEXT OF ACTIVITY THEORY}

In my opinion at least two reasons for invisible seniors' activeness in voluntary work can be indicated. Firstly, it is the lack of seniors' identification with voluntary work as an appropriate place for them where they can learn, develop themselves, 
be active and needed, which probably arises from stereotyped perceiving ageing and volunteering. Secondly, there is a negative picture of an old person in the society. An old person is seen more as a problem than a benefit for the society. This situation results in the limited number of places where seniors can be active and beneficial in the social space. It requires a lot of changes that must occur in understanding ageing and the idea of voluntary work considering a senior as a volunteer. This is a challenge both for seniors and the society.

One of the most popular theories in the 1950s and 1960s, illustrating the potential of ageing, is the activity theory, which (as the disengagement theory) met a critique in the late 1970s. The critique brought the critical branch of political economic gerontology and critical gerontology further on (Powell, 2006). Authors of activity theory are Bernice L. Neugarten, Robert J. Havighurst, Sheldon S. Tobin William E. Henry. I am aware of the critique of this theory; even so I would like to rise some points related to the issue of volunteering work. This functionalist theory postulates how individual behaviour changes with aging and implies how it should change (Powell, 2006). The activity theory supposes that people forming the picture of themselves use two sources such as activities they do and the role they perform in the society (a life). According to the theory of active ageing, while growing old people abandon some roles and assume the others. For example, finishing a career, the role of a worker changes into the role of a senior citizen while the role of a husband and a wife could be replaced with the role of a widow or a widower. According to this theory, changeability and fluidity of roles that we perform in the course of life gives us the possibility to look at the process of ageing as the prospect of change, development and activeness. That being so, the role of an active worker, in the context of a discussed issue, can be replaced with the role of an active volunteer. However, on the other hand, there are seniors who have to deal not only with activity problems but health, marginalization, gender, class and race as well. They feel and are treated as someone less important for society and not equal with others. From that point of view, the activity theory neglects the issue of power, inequality and conflict between age groups that impinge upon the interconnection of race, class, and gender with age (Powell, 2006). Does it mean that the volunteering work is only for active seniors?

Therefore, what is volunteering and is there a place for a senior? And who are the senior volunteers? To frame the extent of the discussed issue, a definition of voluntary work should be quoted to show its wide context. Volunteering is the commitment of time and energy - in an activity that involves spending time, without financial reward, doing something that aims to benefit the community, the environment or individuals outside one's immediate family. At the heart of volunteering is the willingness and ability of citizens to give freely of their time out of a sense of solidarity and responsibility without financial gain.

In our times volunteering became, mainly for young people, a style of life, a way to be active, a manner of spending free time and collecting professional experience. What is seniors' volunteering like? Polish seniors involve in volunteering (Fabiś \& Kędziora, 2006), however, very rarely they define themselves and are described as volunteers. Voluntary activities can be divided 
into informal, non-formal and formal (Rada Unii Europejskiej, 2011). The informal volunteering is diffused in everyday life. The example of informal volunteering is actively at church, neighbourly help, mutual help among friends. This is the most common type of seniors' volunteering. However, as Fabiś and Kędziora's (2006) research shows, the most popular places for seniors' volunteering are hospices. Volunteering in hospices is in nature informal, however, by the organization and structure of hospices, it can be defined as non-formal.

Non-formal volunteering has an organized form but not clearly named as the voluntary work. It means that the volunteers do not have formal state as the volunteers and do not sign the agreement. They do not declare how many hours they want to spend on volunteering work - the time is flexible. Non-formal activities of volunteering can be seen at the Universities of the Third Age (U3A), which enjoy enormous popularity in Poland. There are about 410 of them and every year, month the new ones spring up. The number of these universities and their development prove growing interest and demand for this kind of institutions. In my opinion, activities taken by members of the Universities of the Third Age is an underestimated area of seniors' volunteering. The U3A is a place where the alternative style of ageing is promoted - learning in late adulthood, developing abilities and extending knowledge.

The last kind of volunteering, indicated by the Council of the European Union is formal one. This kind of volunteering has a formal structure. The volunteers sign the agreement with rights and obligations. They declare how many hours they will spend on volunteering work and keep it regular. It means the organization can rely on them and arranges their duties - treats more like workers. The formal volunteering takes place mainly in non-governmental organizations. The most common ones in Poland are PAH (Polish Humanitarian Action), CARITAS, PCK (Polish Red Cross), MOPS (Social Welfare Centre). There are two documents which, to some points, set in order the activity of formal volunteering. First one, the resolution concerning volunteers' insurance introduced in May 2004 by the President of the Republic of Poland, is favourable to volunteers not to organizations. It means that the interest of organizations (especially the small ones) in volunteers can flag (Świątkiewicz \& Mośny, 2004). The second, the conclusion named The role of voluntary activities in social policy adopted by Council of the European Union, is also favourable to the idea of volunteering. This document concerns the role of volunteering in social policy and is the European Union recognition of volunteers and their effort. In the assumption, the purpose of this document is to emphasise that volunteers personify and illustrate European values and aims presented in EU treaties, especially these concerning social cohesion, solidarity and active citizenship (Rada Unii Europejskiej, 2011).

\section{THE PROJECT DESCRIPTION - RESEARCH AREA AND SUBJECT}

The idea of volunteering in the context of ageing, taking formal voluntary activities by seniors referring to learning and being a volunteer in late adulthood is an issue forming the deliberation discussed in this article. Cognitive conduct in the selected 
area was directed by the following detailed research questions: What is formal volunteering like in Wrocław? What factors make it difficult to take voluntary activities? What are the advantages of being a senior volunteer? What do seniors learn while being volunteers?

To gain answers to the research questions mentioned above, in April $2012 \mathrm{I}$ conducted preliminary research among senior volunteers involved in formal voluntary activities in Wrocław, clustered around one of non-governmental organizations - the Active Senior Foundation. The goals of the Foundation are extensive. These confirm the correct choice of research area as the following:

- acting to improve the quality of life and to promote projects, strategies and policy;

- the promotion of lifelong learning;

- action for social matters, labour market research, economic market research;

- activities supporting the development of the local communities;

- the promotion and organization of volunteering.

The main task of the Active Senior Foundation is above all the evaluation, use and development of seniors' competence. The foundation is situated in the building of the Wrocław Centre of Supporting Non-governmental Organizations Sector 3, which is in favour for broadening relations and sharing experience among volunteers at various ages. The Active Senior Foundation cluster 55-plus year-old people, who with their own example prove that it is worth becoming involved in social matters, organizing themselves and taking part in projects on activation and improvement of the quality of life. Every volunteer taking up voluntary work is obliged to familiarize themselves with work ethic and to sign an agreement between a volunteer and an institution, an organization accepting the volunteer, which regulates rules, laws and duties of voluntary activities.

In my opinion, senior volunteers who consciously name themselves volunteers, understand the idea of volunteering broadly and notice its educational values. Therefore the Active Senior Foundation I made the area of research. In the Active Senior Foundation, I distributed 30 questionnaire forms with open ended questions; however, only 16 were given back filled in. Hence research sample consisted of 16 senior volunteers (15 women and 1 men), most of them were aged 60-plus and only one person was 57 years old. More than half respondents ( 9 people) have never had any previous voluntary experience while the others revealed various kinds of informal and non-formal volunteering before being a part of that organization. For example there were activities such as helping in organizing occasional events for children and teenagers, being active in a parent-teacher association, acting in the local Committee of the Rights of the Child, taking care of older people from the local environment, looking after disabled children, assisting a family, friends and sick children. Respondents' time of involvement in volunteering was diverse. Some respondents had been volunteers for a few months while some for a few years (most of them 2-3 years) in that organization. Respondents' time devoted to volunteering was different and dependent on both their abilities and needs of the organization where they helped. Most of the senior volunteers (8) spent about 3-4 hours volunteering weekly, 5 people between 8-12 hours weekly, while a few (3) 
respondents wrote: depending on needs so they did not determine the exact number of hours dedicated to volunteering. Researched senior volunteers had various level of education. Most of the respondents (10 people) had general secondary education and vocational secondary education while the others (6 people) had higher education. It means that the group of senior volunteers are well educated people. In my opinion that factor influences the findings and should be taken under consideration while analysing the results.

\section{THE AREAS OF FINDINGS}

Received data was analysed in the context of learning, being a volunteer and the idea of volunteering. I am aware that obtained material should not be treated as full empirical material but a consideration on a significant problem. It is a 'fragment' of the social world, which can be some justification for further interest in senior volunteering. From the data analysis some areas, presented beneath, were selected.

\section{Understanding the Idea of Volunteering by Researched Seniors}

Referring to the definition given by the Council of the European Union (Rada Unii Europejskiej, 2011), volunteering is an opportunity to learn and can become a catalyst for social changes. Involvement in volunteering allows citizens to gain new abilities and reinforces their social affiliation. The definition is significantly confirmed in the answers given by researched senior volunteers. In respondents' opinion, volunteering is defined as:

A way of retirement ... Helping the needy, mutual learning of tolerance, being yourself, co-existing among generations ... Spending free time, getting new experience ... Devoting time and energy to the local community ... A new challenge ... Supplementing ambition ... Voluntary free conscious work for the others or the society ... Skill-sharing, cooperating with the others ... Finding fulfilment, a pleasure of giving some kindness, some help to the others ... A way of life, gaining some knowledge, giving some joy, getting to know new people and the world ...

From analyses of data an attractive picture of volunteering has emerged. Voluntary work appears to be a place of learning, skill-sharing, development and ability to cooperate with young people (exchanging experience and mutual learning), getting the competence of managing in the contemporary world, a way of life and retirement, the possibility of social involvement as well as self-development. Understanding the idea of volunteering becomes a part of the model of learning to get old, learning by the pictures of ageing and learning in later life (Malec, 2012). However, it needs to be added that the research group consisted of privileged older people - well educated, active and most of them were women. They probably knew that they would not be passive after retiring. They looked for some places (besides the U3A) where they can be useful and share experience with others. 


\section{Volunteering as an Alternative to the Continuation of Career Activeness}

As the analysis shows, volunteering is an alternative to keep career activeness, to gain new experience and interests. To be active both physically and intellectually, to be curious about the world and to get to know it, to reflect on what we experience and to treat work as means to fulfil tasks mentioned above is one of possible scenarios of learning till old age (Malec, 2011). Volunteering allows to fulfil this scenario, which is confirmed by respondents' answers.

After retiring ... willingness to share my interests, abilities and passions with the others ... Filling time instead of working; the lack of boredom ... Getting new abilities, as well as professional and life experience ... I have less free time, but this is what seniors need to feel needed after they retire ....

Retiring generates larger amount of free time. However, more time does not often equal greater involvement in social life, cultivating interests, hobbies for doing which there has been no time earlier. There is often emptiness, apathy, passiveness and the lack of ideas to fill time that was earlier taken by career. Volunteering is a sphere that can fill in this free time.

\section{Volunteering as a Sphere of Breaking Generation Barriers}

Connotation of terms 'old age' and 'old people' are most often negative (Pawlina, 2011). Having senior volunteers among young people breaks generation gap, learns co-existence and cooperation, and is the best testimony to active and passive ageing. It is confirmed by received research results. It is one of the possible ways of 'taming' the youngest with old age. The analysis of senior volunteers' responses about young people shows the positive picture of cooperation. One of the assumptions of the intergenerational learning is a process of changes that needs time, understanding and tolerance. It is building relatively approving relation by both generations. It can be seen in senior volunteers' responses below.

Not always young people believe in seniors' abilities. Sometimes they are overprotective or forget that seniors tick over ... Amazing communication, willingness to cooperate, appreciating seniors' experience ... (Youngsters) are too impatient, sometimes intolerant, sometimes they ignore experienced people's opinion, straight out they despise older people ... can be vigorous, involved, rush to aid, are courteous, cheerful ... I admire them (youngsters). They are very involved in helping, are cheerful, smiling, wonderful. It is a pity that earlier there was no time to devote myself to this activity ...

The last interesting response is given by a female senior volunteer (B16) who expresses both admiration for young people and is a kind of acknowledgement that probably earlier she has seen that differently. Only involvement in volunteering modified the picture of youngsters. Referring to the model of learning ageing, it can be stated that voluntary work is one of these places where young people learn positive ageing by 'living pictures of ageing'. 


\section{The Meaning of Popular Culture, the Media for the Development of Volunteering}

The media, popular culture (films, commercials, sitcoms) are optimal places to promote senior volunteering and learning ageing by positive pictures of ageing. In responses to the question - what could be useful to make more volunteers involve in voluntary work, there was often mentioned the aspect of the media, which is proved by respondents' answers below:

Permanent activeness of offers for seniors in the mass media ... Presenting (the idea of volunteering) in the media ... Publicising (senior volunteering) more in the media ( $\mathrm{B} 8$ ) ... advertising what can be done there (in volunteering) as generally it is believed that it is only based on helping in hospices ... Informing (in the media) about the possibility of acting for other people ...

Propagating senior volunteering in the media not only would increase the awareness of viewers on the idea of volunteering and volunteers but also would encourage seniors to take this form of activeness. Presenting the picture of an active senior volunteer not only would 'accustom' to aging, but also would 'allow' a senior to exist in the public sphere, in the media.

The next sphere of learning ageing by the presence of older people is a place of the general public. In these places the older adults are often 'transparent' unnoticeable. Their presence in a theatre, a cinema, cafes, pubs, at concerts, exhibitions, universities is minimal (Malec, 2011). An old person is often treated like an object, as an unnecessary, hampering and problematic element. A senior as a volunteer is rarely seen in the public sphere. An example is the Great Orchestra of Christmas Charity organized every year by Owsiak, gathering a lot of volunteers mainly young ones. There are few senior volunteers.

Rousing, moulding the awareness of the older adult's presence in the society, often deprived of rights, pushed into the social background, is a challenge issued to widely understood education. As Aittola (1998: 107) claims, learning is an elementary part of everyday life world, and its practical activities and all spheres of everyday life and action situations should be regarded and studied as meaningful learning environments.

\section{Volunteering as a Sphere of Non-formal Learning}

As the conducted research shows, volunteering - cooperation with young people, co-existence, skill-sharing, exchanging views - helps seniors in self-reflection on their life. It determines changes in opinions, assumptions, seeing themselves, the others and the world. Researched senior volunteers want to learn non-formal as well. They would like to take part in various types of courses, which is confirmed by responses below.

Courses on the possibility how to help the others in various situations ... Courses improving qualification of knowledge, of volunteering for the needy and the society ... Computer and language courses ... (courses) how to 
manage time ... Workshop on assertiveness, communication among various groups of people ... First aid courses ...

The analysis of received empirical material shows that being involved in volunteering work helps seniors to notice new abilities which could be improved and developed. I would like to stress that in the research group there were the well educated people thus learning was well recognized. As Field (2002) claims, adults train and take part in organizing their education during the whole life, and nonformal learning spread to their everyday life. However, most of the time when we retire we start to notice our life has less values and we do not see ourselves as learners. The stereotypical imagination about old age puts seniors into a passive position and causes an uncommitted person. In my opinion seniors need the impulse and reinforcement to be active. Older people need to believe that they are an important part of the society (the useful one) and that they can learn. Obviously, one of the places where seniors can get that impulse and improve their skills is volunteering, but it is only for some privileged people.

\section{Volunteering as a Place of 'Becoming a Better Person'}

Being a volunteer increases self-confidence and gives the possibility of checking their capabilities and abilities. All researched senior volunteers benefit from involving in voluntary work. Voluntary activities provide the possibilities of meeting interesting people with whom they can exchange experience, share interests. Co-existence gives the opportunity to develop communication and interpersonal skills. It is illustrated by senior volunteers' responses as below.

My circle of friends has expanded, I have gained some knowledge, I feel needed ... I have discovered such possibilities I did not have the foggiest idea about ... (I learn) human relationships ...

Senior volunteers learn to understand and listen to the others, humbleness, patience and tolerance. They open to the wider cognitive perspective, build confidence and learn the distance to themselves, which is confirmed by responses below.

(I learn) humbleness and patience ... I learn patience, love and understanding other people ... I am becoming more and more tolerant ... I have become a person more open to the other person (B6); Acquiring self-confidence ... Keeping the distance to myself, listening to the others, diplomacy ...

As researched senior volunteers believe, involvement in volunteering strengthens character. They learn to be punctual and how to solve problems. Thanks to voluntary activities, they find the sense of life, raise self-esteem and gain knowledge about the value and significance of volunteering. From the analysis of senior volunteers' responses it appears that involvement in volunteering have carried out a transformation in themselves, they have become 'better people', more optimistic and open to themselves, the others and the world. Senior volunteers helping in voluntary activities learn about themselves, the others and the world. 
The world that is full of meanings and symbols. A person being a component of this world learns to exist in this world continually. As Jarvis (2007: 1) claims, learning is the combination of processes throughout a life time whereby the whole person - body (genetic, physical and biological) and mind (meaning, knowledge, skills, attitudes, values, emotions, beliefs, and senses) - experiences social situations, the content of which is then transformed cognitively, emotively or practically (or through any combinations) and integrated into the individual person's biography resulting in a repeatedly changing person.

The analysis of data shows that volunteering like learning, following Jarvis (2007), engages body, mind and brings experience that causes person's biography resulting in a more experienced person. The volunteering work gives possibility to meet 'the other' - who thinks and behaves differently - who is just different than we are and our micro-world. That meeting can work as the impulse to change us as the person, which had happened with some of the researched seniors.

\section{CONCLUSION}

As the results of a small research project have showed, the experience of feeling fulfilment, satisfaction, learning (both old people and young people from old ones) and becoming 'a better person' are significant reasons for which it is worth involving in volunteering. Voluntary work creates the opportunity for older people to increase the quality of their life and gives the society the possibility of using the older adult's energy, experience and knowledge. Promoting a positive picture of ageing and old person, also in the sphere of volunteering, is a challenge for the society and education. Advantages of being a volunteer are multidimensional. Older people involving in volunteering help the others, support each other, but also present an attitude of an active senior in the rapidly changing world. Being a volunteer reduces, overcomes isolation and withdrawing as well as is the exemplification of an active life and ageing.

Voluntary activities give the older adults self-esteem and the feeling of social importance. They help in changing the way they perceive themselves as learners and these who 'give' and not unnecessary those who 'take'. Breaking a stigmatizing stereotype of the worthless other - the old one by older people themselves is one of crucial social tasks. Volunteering is a sphere where there is learning till old age, by the pictures of ageing and in later life (Malec, 2012). Conducted research presents the positive picture of senior volunteer, however, to show specificity (of needs, problems, benefits) and confirmation of proposed conclusions, interdisciplinary research considering broader contexts should be taken. However, volunteering work does not have only positive sides, of course. There are also 'traps' and difficulties to meet while doing volunteering work. One of the 'traps' is abusing the time and experience of senior volunteer by an organisation, an institution or a person. A senior involves in volunteering work and being appreciated by others can lose the ability of estimating where the border between volunteering and exploitation is, especially when she/he feels lonely. Another trap can appear when the senior volunteer will get too many duties, 
without any support, which can overwhelm her/him. Most of seniors present quite low self-confidence so any of problems, difficulties put them down very easily. It can be manifested by depression or auto-marginalization. There are not so many places open for seniors, thus other difficulties could be such as finding a place for being a volunteer at the age over 60 (particularly formal volunteering). As the findings show the researched group consisted of privileged older people (welleducated and active) who are brave enough to look for some activities. While there are a lot of older adults who do not have 'high' education but can offer a lot as volunteers. What about them?

One more issue which needs to be considered in sights of the research is gender. Most of the researched seniors are women. Probably it is connected with roles which they undertook earlier - they were active (busy with a lot of duties) as a mothers, wives, workers and daughters as well. Thus, becoming a senior they want to continue the activity or maybe there is another reason?

To conclude, I would like to put some questions for reflection. First, does it seem that voluntary work is only for active and well educated women? Why are men not visible as volunteers? How much does gender matter on the volunteering work? What about not well educated older people (women)? What about older adults who are passive? Is it possible to encourage them to become volunteers? And what about people who live in the small local community? Do they have any chance to become volunteers?

\section{REFERENCES}

Aittola, T. (1998). Reflections on learning in everyday life. In A. Bron, J. Field, \& E. Kurantowicz (Eds.), Adult education and democratic citizenship II (pp. 103-119). Kraków: Impuls.

Fabiś, A., \& Kędziora S. (2008). Wolontariat hospicyjny seniorów. In A. Fabiś (Ed.), Aktywność społeczna kulturalna i oświatowa seniorów. Biblioteka Gerontologii Społeczne (pp. 73-81). Bielsko Biała: Wyższa Szkoła Administracji w Bielsku-Białej.

Field, J. (2002). Lifelong learning and the new educational order. Stoke on Trent and Sterling: Trentham Books.

Jarvis, P. (2007). Globalisation, lifelong learning and the learning society. Sociological perspectives. Vol. 2. London: Routledge.

Komunikat z badań. (2011). Warszawa. Accessed 18 January 13 from: http://www.cbos.pl/ SPISKOM.POL/2011/K_063_11.PDF

Malec, M. (2011). Poszukiwanie recepty na starość - wyzwaniem dla edukacji dorosłych. Refleksje nad uczeniem się starości przez całe życie. In M. Malec (Ed.), Edukacyjne, kulturowe i społeczne konteksty starości (pp. 11-28). Wrocław: ATUT.

Malec, M. (2012). Learning in later life and the construction of meaning: biographical research and the 'signposts of life'. International Journal of Education and Ageing, 2(3), 197-210.

Pawlina, A. (2011). Stereotypowe wizerunki starości w wybranych przekazach kulturowych. In M. Malec (Ed.), Edukacyjne, kulturowe i społeczne konteksty starości (pp. 139-155). Wrocław: ATUT.

Powell, J. L. (2006). Social theory and aging. Oxford: Rowman/Littlefield Inc.

Rada Unii Europejskiej. (2011). Rola wolontariatu w polityce społecznej-Konkluzje rady. Accessed 20 June 2013 from http://register.consilium. europa.eu/ pdf/ pl/ 11/st14/st14552.pl11.pdf

Seniorze jesteś potrzebny. (2012). Seniorze jesteś potrzebny. Accessed 16 September 2014 from: http://www.wszczecinie.pl/aktualnosci,seniorze_\%E2\%80\%93_jestes_potrzebny,id-21020.html 
Świątkiewicz, \& Mośny, M. (2004). Wolontariat jako cnota i instytucja obywatelska. In M. S. Szczepański \& A. Śliz (Eds.), Obywatel w lokalnej spoteczności. Studia i szkice socjologiczne (pp. 163-169). Tychy-Opole: Wyższa Szkoła Zarządzania i Nauk Społecznych, Uniwersytet Opolski.

Szatur-Jaworska, B., Błędowski, P., \& Dzięgielewska, M. (Eds.). (2006). Podstawy gerontologii spolecznej. Warszawa: Oficyna Wydawnicza ASPRA-JR.

Matgorzata Malec-Rawiński

Institute of Pedagogy

University of Wroctaw

Poland 

SECTION 3

INTERGENERATIONAL LEARNING 



\title{
12. DIFFERENT CONCEPTS OF GENERATION AND THEIR IMPACT ON INTERGENERATIONAL LEARNING
}

\begin{abstract}
INTRODUCTION
In recent years, intergenerational learning has become a major topic in research. Nevertheless, a theory of intergenerational learning is still missing and empirical research seems to deliver very different results as investigations are usually related to just one scenario of intergenerational learning. The term 'intergenerational learning' is used for a broad range of activities in which the participation of people of different age seems to constitute the only common ground for all these types of learning. The categorization of intergenerational learning activities and the differentiation of types of intergenerational learning can be seen as an important first step on the way to an integrated theory of intergenerational learning. In this context, it might be useful to look at different understandings of the term "generation" within educational arrangements. Basically, one can distinguish between a genealogical, a pedagogical, and socio-historical concept of generation. Furthermore, it seems to be necessary to distinguish between generations and agegroups, because the latter term is not accurate enough with regard to learning arrangements which are supposed to be intergenerational. The term intergenerational should only be used if participants in a learning activity are addressed as representatives of their generation or of their birth cohort, and not as representatives of an age-group. In a second step, different types of intergenerational learning can be differentiated according to their aims and to the significance of intergenerational interaction for the learning process. Thus, existing evaluation studies and other sources of empirical evidence can be linked with the heuristic model of intergenerational learning before it is related to tasks and challenges for learners and teachers in intergenerational scenarios.
\end{abstract}

\section{THE MEANING OF THE TERM 'GENERATIONS'}

In the beginning, relations between and sequences of generations were introduced to life sciences as a research object. Research projects in biology, in particular, have been dedicated to sequences of generations of organisms, to the heredity of genetic characteristics from one generation to the next and to generative behavior in the sense of reproduction. In these contexts, the term generation has been used to describe the reproduction of a species based on a sequence of generations with similar genetic material (Höpflinger, 1999: 6f.). The term generations was also 
used in science to refer to a cyclic model, and as a basis for calculating the age of mankind, or as a category of cultural history (see Parnes et al., 2008: 10). The socalled genealogical idea of generations follows the biological approach and was introduced to social sciences by detaching it from its biological context and by conceiving of human generations as a constellation of relationships. When thinking of children, parents, and grandparents as generations within the family, then belonging to a generation also implies the assignment of roles which change more than once during a lifetime. Associating a human being with a certain generation thus is related to a stage of life and not to the year of birth.

Another meaning of generation addresses the future development of societies. In the late 18th century, the development of societies was seen as an ongoing story of progress and generations were conceived of as categories of that progress. Through its historical connotations, the term generations, which was used as a term with a specific meaning in sciences before, became part of the everyday language (ibid.). In line with that sociological paradigm, Mannheim (1928) formulated his concept of generations based on the idea that the significance of historical events for the development of individuals depended on their age and the phase of life during which they experienced those events. According to Mannheim, certain cohorts in a culture are tied together by the experience of crucial historical events during a certain phase of their lives. In order to form generations, these events have to be linked with drastic changes in society and with short-term changes in people's lives (e.g. Second World War). This concept of generations is free of any hierarchical order of generations, e.g. based on time of birth; the idea is that only shared experiences of socialization can create a sense of a common ground, of belonging to one generation based on specific values, attitudes, and patterns of interpretation.

No matter which concept of generation is being used, generations are always constructs in the sense of an ideal type (Weber, 1922; Schmidt-Hertha \& Tippelt, 2011), designed for a specific purpose. This can be the description of cultural phenomena, the construction of a collective identity, or a line of reasoning in political discussions on the distribution of resources in a society. Generation concepts can also be used to describe relations between different age-groups and cohorts (Schmidt-Hertha, in press).

\section{DIFFERING USES OF THE TERM 'INTERGENERATIONAL LEARNING'}

Hand in hand with the different concepts of generations goes a broad range of diverse understandings of intergenerational learning (Gadsden \& Hall, 1996). These differ according to the arguments given for intergenerational learning, its aims, and the perception of which learning arrangements may actually be called intergenerational and which problems might arise. Even though there seems to be a strong consensus in educational research on the need for and the positive influence of intergenerational learning, the reasons given differ immensely. On the one hand, intergenerational learning is seen as a way of compensating the decreasing contact between the generations in different spheres of life (workplace, associations, families, etc.) (Lohman et al., 2003), and of thus setting up an intergenerational 
dialogue which is of great significance to the cultural and social development of a society. On the other hand, it is argued that intergenerational learning brings together the innovative ideas of young people with the life experience of the older ones, thus creating new potentials (e.g. McGuire et al., 2007).

In accordance with that line of reasoning, the aims of intergenerational learning differ similarly. Some sources point to the importance of intergenerational exchange in that it addresses perspectives, needs, and ideas of different generations and thus strengthens intergenerational solidarity within a society. This approach is usually found in non-vocational adult education (Lohman et al., 2003), in particular in the field of political education. Others refer to a greater effectiveness of learning when each generation contributes its individual expertise and the aim is to gain knowledge and skills for all generations participating in a common process of learning. Especially intergenerational programs in continuing vocational education often aim at the compensation of generational deficits (e.g. the lack of digital literacy of older workers) (Schmidt-Hertha \& Thalhammer, 2012).

When looking at the literature available, one may gain the impression that almost all forms of learning involving actors of different ages might be called intergenerational. Sometimes learners and teachers belong to different generations (Strom \& Strom, 2000), sometimes learning groups are age-heterogeneous in themselves (Ayers \& Narduzzi, 2009). In some cases, age-related experiences become important for the learning process; in others, differences in generational background seem to be essential to the learning process (Franz, 2010a). Some programs bring together people with a maximum age difference (children and seniors) who are attributed different roles - sometimes seniors are supposed to learn from youngsters, sometimes it is the other way round. Partly, these roles are set by institutions, for instance when the younger ones participate in specific forms of intergenerational learning during their school lessons - and thus not really voluntarily - or when the older ones are addressed as people in need of care, faced with social exclusion. In other settings, the age-differences are not that big, for instance when older and younger workers join together or when ageheterogeneous groups are established in adult education courses (Tikkanen et al., 2002).

the broad range of learning scenarios given the label 'intergenerational' comes with highly diverse challenges and manifold problems arising within these learning arrangements. In many cases, when different roles are attributed to different generations, it seems to be difficult to attract different age-groups alike. It can often be observed that the ones supposed to learn seem to be less interested in participating than the ones supposed to teach, and so methods meant to motivate extrinsically are being introduced. For instance, when older adults come into school, e.g. to join classroom discussions, the students are not there by choice. In other scenarios with equal roles, challenges are related to differences in the prior knowledge of learners and in their learning objectives, which may cause problems if conflicts between the generations arise (Siebert \& Seidel, 1990). 
One has to be aware of the fact that although learning together can strengthen solidarity among the generations, it may in the same way harden incomprehension and alienation. Promoting empathy between the generations presupposes an understanding for various points of view of different generations and for their specific interpretive paradigms. To create such an understanding and to solidify solidarity thus have to be explicit aims of intergenerational learning arrangements.

\section{FORMS OF LEARNING IN AGE-HETEROGENEOUS GROUPS}

The concept of generations and the aims of learning arrangements are only two out of a bundle of dimensions that can be taken into account when intergenerational learning scenarios are described. In order to apply a heuristic concept of different modes of intergenerational learning, Siebert and Seidel (1990) propose to differentiate three forms, namely learning from each other, learning together and learning about one another. The central criterion here is the nature of the interaction in the learning process.

Learning together here means that learners belong to a different generation than teachers, so that one could speak of one generation learning from the other. This is true for most learning scenarios in schools, vocational training or higher education, where teachers are usually significantly older and belong to another generation than their students. However, this can also be the other way round in adult education, e.g. when looking at computer courses for seniors or something similar. To apply the term intergenerational learning here would mean, on the one hand, that most learning scenarios we know of can be called intergenerational. On the other hand, it remains unclear in how far generational values, attitudes and patterns of interpretation are of significance to that type of learning and in how far either one of the aims mentioned above is addressed here. As long as the learning process is not guided by the generational background and does not even include experiences of different generations, the label 'intergenerational learning' should not be applied here.

The situation may differ when learners belong to different generations and cope with the learning content together in age-heterogeneous groups. This learning together has the potential of making use of different generational perspectives on the learning content and of contributing to the aims of intergenerational learning. However, not every scenario with age-heterogeneous groups of learners should be called intergenerational as long as intergenerational interaction is not used as an important resource for learning. This interaction requires non-hierarchical communication between the learners as well as elements of collaborative learning and it needs to be ensured that all learners have the same right to learn new things and to contribute their experiences (Lohman et al., 2003).

Finally, learning about one another means that generational perspectives and interpretation patterns are not only used for learning, but are part of the learning content and the learning objectives of age-heterogeneous groups. Siebert and Seidel (1990) call this the true form of intergenerational learning that, even today, 
is realized in but a few of the projects labeled 'intergenerational' (Rute \& Fragoso, 2013). When educational settings provide the opportunity to learn about different perspectives of different generations, to reflect on one's own generational attitudes, and to gain a deeper understanding of other generations, then intergenerational learning becomes much more than simply bringing together people of different ages in a common learning environment. This learning about one another can take place informally (Rute \& Fragoso, 2013; Field, 2012), but also within institutional settings; in the latter case, however, it requires adult educators trained specifically for this type of learning arrangements (Franz, 2010b).

\section{STATE OF RESEARCH ON INTERGENERATIONAL LEARNING}

In a first phase of research on intergenerational learning carried out in the 1980s and 90s, which had been dominated by research work from the United States, the focus was on intergenerational learning and knowledge transfer within the family (Gadsden \& Hall, 1996). A genealogical concept of generations was applied to learning processes among parents, grandparents and children and, in accordance with that line of research, educational programs were conceptualized to prepare grandparents for their learning and teaching duties within the family (Strom \& Strom, 2000). Without doubt, learning within the family constitutes an important research field and there are still many questions that remain unanswered and are in need of further investigation. However, intergenerational learning occurs on many occasions and also takes place outside the family - a fact that, in recent years, has been addressed by many European researchers.

So far, recent empirical studies have mostly focused on the interest in and the readiness for intergenerational learning among older adults. This research reveals a high level of openness and willingness among older people to get together with younger generations and also to participate in intergenerational learning. Older adults with a higher level of activity and civic engagement are more likely to be interested in intergenerational learning. The same is true for older adults with a more positive image of ageing and more contacts with younger generations (Schmidt-Hertha \& Thalhammer, 2012). There still is a lack of studies on the willingness of younger generations to participate in intergenerational learning. Existing studies exclusively focus on those learners that already participate in intergenerational programs, but not on a representative sample of all younger adults. In other words, so far, research has only been done on younger participants in and not on younger addressees of intergenerational learning. A specific context here is the field of higher education, where older and younger learners are brought together non-voluntarily. Here, an older study points to a couple of problems arising from differing learning aims pursued by older and by younger learners (Siebert \& Seidel, 1990), something that is not to be expected likewise for the field of adult education.

Whether older adults are open to intergenerational learning often depends on the content of learning. When looking at current research reports, it seems that projects of intergenerational learning frequently address topics that can be expected to 
produce a gap between the generations regarding prior knowledge. The most obvious and most common of these topics is digital media (Schmidt-Hertha \& Thalhammer, 2012; Schäffer, 2003). ICT is seen as a domain of the younger generations, also addressed as 'digital natives' (Trinder et al., 2008). Teaching the older ones how to use computers or the internet seems to be a widespread aim of intergenerational learning scenarios (Patricío \& Osorio, 2012), although most of these belong to the category of learning from one another and so cannot be called "intergenerational learning" in the sense described above. Vice versa, members of the older generations are addressed as experts within intergenerational groups whenever the learning content is related to giving support in difficult life situations or moments of transitions, or to imparting experiential knowledge (Franz, 2006). In any case, a gap between the generations due to differences in prior knowledge constitutes an obstacle to intergenerational learning as the learning process is then dominated by a hierarchy of generations based on their knowledge regarding the learning content.

According to diverse research reports and evaluation studies, project-oriented learning with a common aim beyond the learning process itself is a good vehicle for intergenerational learning (see Chapter 13 by Barry Hake in this volume). When learners of different generations act together to change their own situation or to improve support and facilities for other people (e.g. marginalized groups), the joint project is often a good example to illustrate the significance and the impact of diverse generational perspectives and of generational knowledge. Looking for new solutions has in many cases the potential to make learners think about their own experiences and to awaken interest in the experience of others (Rute \& Fragoso, 2013). In research literature, these projects are often labeled 'intergenerational service learning', even though most activities are somehow nonreciprocal. Intergenerational service learning often implies that one generation is committed to another or supports another and thus generations act together not as equals, but as givers and takers, supporters and supported, service providers and service consumers. There are many studies showing positive effects of intergenerational service learning on images of ageing, on the reduction of stereotypes, on the gathering of experiential knowledge for the younger generations (Kalisch et al., 2013), as well as on social inclusion, and physical and mental wellbeing of the older generations participating in these programs (Hernandez \& Gonzalez, 2013).

\section{DESIGNING INTERGENERATIONAL LEARNING - TASKS AND CHALLENGES}

As research has shown, there are at least three core principles that may guide the development of intergenerational learning programs. Firstly, intergenerational learning has to address or at least to allow for learning about one's own generation and about others. The interaction of generations is driven by their specific generational background, their perspectives and attitudes and therefore these generational characteristics have to be reflected by and should be considered an important part of learning. Secondly, intergenerational learning has to be seen as 
reciprocal. When all generations involved act as both learners and teachers, when they meet without hierarchies and have equal opportunities to control the learning process, then it is possible to learn about the other generations in a sustainable and effective way. Thirdly, project-oriented learning and service learning seem to be highly successful strategies of achieving positive results with intergenerational learning. Not only for older learners it seems to be an important source of motivation to combine learning processes with commitment and aims beyond learning itself.

Thus, intergenerational learning can provide a rich set of learning opportunities and opportunities for personal development. Nevertheless, it also constitutes a challenge for learners and adult educators. Even within the family, a certain preparation for intergenerational learning seems to be helpful (Strom \& Strom, 2000), just as it is in contexts outside the family's intimacy. It appears that not all adults are willing and prepared to participate in intergenerational learning (see Schmidt \& Tippelt, 2009) and some of them need a gentle introduction to that type of learning scenarios. Likewise, it is a challenging task for adult educators and other professionals initiating and moderating intergenerational learning scenarios to realize such learning events. It seems obvious that professionals have to be prepared for such tasks; therefore Franz (2010) developed a preliminary concept for training adult educators in the field of intergenerational learning. This concept is based on a qualitative case study and focuses on the challenges of learning about one another and on possible conflicts between the generations.

Although most intergenerational learning programs will not be able to fulfill all three aspects described above, they nonetheless offer important contributions to intergenerational learning and to the intergenerational dialogue. Further discussion is required on the question of when a learning arrangement can be called intergenerational and of how broadly or narrowly the label should be interpreted. Currently, there seems to be a lack of clear notions of what the term 'intergenerational learning' really means and of what it should be applied to. It seems obvious that simply bringing together people of different age groups in one learning scenario cannot be a sufficient criterion.

\section{REFERENCES}

Boström, A. (2012). Intergenerational solidarity - and the need for lifelong and lifewide education to enhance community well-being. In S. J. Krašovec \& M. Radovan (Eds.), Intergenerational solidarity and older adults' education in community (pp. 47-55). Ljubljana: University of Ljubljana.

Field, J. (2012). Transitions, generations and informal learning in later life. In S. J. Krašovec \& M. Radovan (Eds.), Intergenerational solidarity and older adults' education in community (pp. 79-86). Ljubljana: University of Ljubljana.

Franz, J. (2006). Die ältere Generation als Mentorengeneration - Intergenerationelles Lernen und intergenerationelles Engagement [The older generation as a generation of mentors - Intergenerational learning and intergenerational engagement]. Bildungsforschung 3/2. Accessed on 16 September 2014 from: http://www.bildungsforschung.org/index.php/bildungsforschung/article/view/36 


\section{SCHMIDT-HERTHA}

Franz, J. (2010a). Social cohesion and intergenerational learning arrangements. In Online Documentation of the Conference The Impact of Cultural and Citizenship Education on Social Cohesion, Vilnius, December 2009. Published on the website of NECE. Accessed 1 June 2010, from: www.bpb.de/files/XR5A1H.pdf.

Franz, J. (2010b). Intergenerationelles Lernen ermöglichen. Orientierungen zum Lernen der Generationen in der Erwachsenenbildung [Facilitating intergenerational learning. Orientations to learning of generations in adult education]. Bielefeld: wbv.

Gadsden, V. L., \& Hall, M. (1996). Intergenerational learning: A review of the literature. Philadelphia: NCOFF.

Hernandez, C. R., \& Gonzalez, M. Z. (2008). Effects of intergenerational interaction on aging. Educational Gerontology, 34(4), 292-305.

Höpflinger, F. (1999). Generationenfrage - Konzepte, theoretische Ansätze und Beobachtungen zu Generationenbeziehungen in späteren Lebensphasen [Question of generation - Concepts, theoretical approaches, and observations on relationships of generations in later life]. Lausanne: Réalités Sociales.

Kalisch, H. R., Coughlin, D. R., Ballard, S. M., \& Lamson, A. (2013). Old age is a part of living: Student reflections on intergenerational service-learning. Gerontology \& Geriatrics Education, 34(1), 99-113.

Lohman, H., Griffiths, Y., Coppard, B. M., \& Cota, L. (2003). The Power of book discussion groups in intergenerational learning. Educational Gerontology, 29(2), 103-115.

Mannheim, K. (1928). Das Problem der Generationen [The problem of generations]. Kölner Vierteljahreshefte für Soziologie, 7(2), 157-185, 7(3), 309-330.

McGuire, D., By, R. T., \& Hutchings, K. (2007). Towards a model of human resource solutions for achieving intergenerational interaction in organisations. Journal of European Industrial Training, 31(8), 592-608.

Parnes, O., Vedder, U., \& Willer, S. (2008). Das Konzept der Generationen. Eine Wissenschafts- und Kulturgeschichte. Frankfurt A.M.: Suhrkamp.

Patrício, M. R., \& Osorio, A. (2012). How can intergenerational learning with ICT help to strengthen intergenerational solidarity? In S. J. Krašovec \& M. Radovan (Eds.), Intergenerational solidarity and older adults' education in community (pp. 288-295). Ljubljana: University of Ljubljana.

Rute, R., \& Fragoso, A. (2013). Older men learning in the community: The case of the amateur fishing club of Faro. In I. Žemaitaityte \& S. Mikulioniene (Eds.), Proceedings of 4th International Conference on Learning Opportunities for Older Adults: Forms, Providers and Policies (pp. 77-88). Accessed 16 September 2014 from: http://eloa.mruni.eu/wp-content/uploads/2012/11/ELOA_ebook.pdf.

Schäffer, B. (2003). Generationen - Medien - Bildung. Medienpraxiskulturen im Generationenvergleich. [Generations - Media - Education. Cultures of media practice in generational comparison]. Opladen: VS Verlag.

Schmidt, B., \& Tippelt, R. (2009). Bildung älterer und intergeneratives lernen [Education of elderly and intergenerational learning]. Zeitschrift für Pädagogik, 1(55), 74-90.

Schmidt-Hertha, B., \& Thalhammer, V. (2012). Intergenerative aneignung von medienkompetenz in informellen kontexten [Intergenerational acquisition of media competence in informal contexts]. In: A. Hartung, B. Schorb, \& Kuttner C. (Eds.), Generationen und Medienpädagogik. Annährungen aus Theorie, Forschung und Praxis (pp. 129-148). München: kopaed-Verlag.

Schmidt-Hertha, B., \& Tippelt, R. (2011). Typologien [Typologies]. Zeitschrift für Weiterbildungsforschung, 34(1), 23-35.

Siebert, H., \& Seidel, E. (1990). SeniorInnen studieren. Zwischenbilanz des Seniorenstudiums an der Universität Hannover [Seniors study. Provisional evaluation of senior study programme at the University of Hannover]. Hannover: ZEW.

Strom R., \& Strom S. (2000). Intergenerational learning and family harmony. Educational Gerontology, 26(30), 261-283. 
Tikkanen, T., Lahn, L. C., Withnall, A., Ward, P., \& Lyng, K. (2002). Working life changes and training of older workers. Brussels: European Commission.

Trinder, K., Guiller, J., Margaryan, A., Littlejohn, A., \& Nicol, D. (2008). Learning from digital natives: Bridging formal and informal learning. Accessed 16 September 2014 from: http://www.academy.gcal.ac.uk/ldn /LDNFinalReport.pdf.

Weber, M. (1922). Gesammelte Aufsätze zur Wissenschaftslehre [Collected papers on philosophie of science]. Tübingen: Mohr Siebeck.

\section{Bernhard Schmidt-Hertha \\ Institute of Education \\ University of Tübingen \\ Germany}





\title{
13. WHAT GROWS IN GARDENS?
}

\author{
Perspectives on Intergenerational Learning in Urban Spaces
}

\section{INTRODUCTION: INTERGENERATIONAL LEARNING}

In European societies, demographic, societal and economic change - such as the decline of extended families, longer expectancy and the ageing of the population, rural decline, urbanization, increased geographical mobility, complex transportation infrastructures, the emergence of ICTs and the internet - have contributed to different generations becoming more distanced and/or more segregated from each other. On the one hand, these forms of geographic, social and cultural separation can lead to unrealistic, sometimes negative, stereotypes between the generations and a decrease in positive social exchanges between them when there are fewer meeting-points in day-to-day life. On the other hand, the different generations may possess resources that are valuable to each other and which they can share in areas of concern directly affecting their lives. Intergenerational learning is thus perhaps one way of addressing the significant demographic changes we are experiencing in European societies and the generation gap in 'greying' societies. It can involve people from different generations becoming engaged in learning from each other and learning together. In this respect, intergenerational learning can make an important contribution to lifelong learning throughout individual life courses, where the generations work together in communicating and acquiring knowledge, skills, and sensitivities. Intergenerational learning can foster reciprocal learning relationships between different generations and help to develop social capital and social cohesion in ageing societies, for both the young and the old. It can become a strategy for seeking to enhance intergenerational solidarity through 'intergenerational learning practices'.

Intergenerational learning practices can be increasingly identified in policy documents, policy-making, policies, programmes and projects at the European, national, regional and local levels. These all involve deliberate and sustained efforts to socially organize the reciprocal communication and acquisition of knowledge, skills and sensitivities between generations. This was most recently the case during the European Year 2012 which was devoted to active ageing and intergenerational solidarity. It is possible to identify three main types of intergenerational learning practices as transfer, transactional, and transformative learning. Transfer learning concerns linear communication and acquisition of knowledge, skills, and sensitivities between generations, for example when youngsters teach ICT skills to older people, and older people tell stories about their lives to kids in schools. Transactional learning involves the negotiation of 
voluntary and mutual exchange between the generations of knowledge, skills, and sensitivities through learning exchanges, voluntary associations, clubs, and churches. Transformational learning refers to the mutual development of knowledge, skills and sensitivities between the generations in self-organized learning communities based upon commonly shared problems in day-to-day life in streets, neighbourhoods, communities, action groups, and social movements. In some measure these forms of intergenerational correspond to the widely accepted distinction between formal, non-formal and informal learning. Transfer learning as intergenerational learning activities in schools can be regarded as formal learning. Transactional learning can be seen as out-of-school intergenerational learning activities in the form of non-formal learning. Finally, transformational learning understood as intergenerational learning activities in communities can be regarded as informal learning.

\section{RESEARCH ON INTERGENERATIONAL LEARNING}

The frame of reference adopted here is based upon two generic documents which offer a common framework for the analysis of intergenerational learning practices (Newman \& Hatton-Yeo, 2008; Schmidt \& Tippelt, 2009).

\section{Intergenerational Learning as 'Family Learning'}

The most longstanding focus in the research literature is concerned with the tradition of intergenerational solidarity within (extended) families, and thus with an emphasis on the context of 'family learning'. Within this perspective, intergenerational learning between the generations is viewed, on the one hand, to a large degree in terms of the informal learning and the contribution of older family members, such as parents and grandparents, to the 'intergenerational transmission' of knowledge, skills and values and the learning by children and youth in formal educational settings, for example, literacy. On the other hand, research is also devoted to the informal transmission of what children learn in formal education upon the knowledge, skills, and values of the older generation, for example, in the context of environmental education. The emphasis in this kind of research is upon 'cognitive gains' in terms of knowledge and skills, together with 'affective' spillovers, such as attitudes and values, arising from these forms of informal intergenerational transmission.

\section{Intergenerational Service Learning}

From the 1970s onwards, secondly, there has been a significant emphasis in research into the effects of intergenerational learning in terms of 'intergenerational programmes'. These programmes are generally recognized in the research literature as 'intergenerational service learning' based upon intergenerational transfers of knowledge, skills and values in formal educational institutions. Much of the research on 'intergenerational service learning' focuses on how encounters 
with older people can enhance the outcomes of the academic and professional training of young people in relation to their future occupations as professional counsellors, nurses, carers, social workers of older people. Such research is largely focused on enhancing the knowledge, skills and attitudes of young people engaged in academic and professional education and training - courses preparing for nursing, social work, caring and health careers - who will work with older adults during their professional lives. Research studies in this area tend to measure the cognitive outcomes for the young people in terms of their professional knowledge, while skills are measured in terms of social-emotive skills, and attitudes - such as empathy - in terms of understanding the problems of older people. Such research has devoted little attention to the returns to the older people involved in intergenerational service learning.

\section{Shared-site Intergenerational Learning}

It is possible to identify a clear trend in the recent literature towards research into so-called 'shared site' intergenerational learning where the generations meet in associational and community contexts outside of formal educational institutions. Shared-site intergenerational learning is focused on non-formal learning environments where different generations learn together and from each in relation to common concerns shared by the generations, such as volunteering, clubs, associations, churches, heritage, hobbies, sports, museums, galleries, theatres, concert halls, and the performing arts including dance, music, singing, drama, film in addition to the plastic arts. More recently, research is also focused on non-formal learning in the workplace as a relevant shared site for intergenerational transactions. There is also evidence in the research literature of a growing research interest in the intergenerational dimensions of virtual spaces such as social networking via Facebook and Twitter. In terms of the outcomes of this non-formal intergenerational learning in shared real and virtual sites, there is a significant shift towards an awareness of the wider benefits of learning for older people as stakeholders in the 'learning society' and the need to develop 'life-wide' lifelong learning. The focus in research assessing outcomes from shared site non-formal learning is upon the spill-overs which enrich the quality of the lives of 'seniors' themselves, and enhance their own specific contribution to intergenerational transactions rather than the transfer of knowledge, skills and values from one generation to another. This leads away from intergenerational 'transfer learning' towards the recognition of the importance of non-formal and informal learning in terms of 'transactional learning' in the sense of learning things together by 'doing things' together. As such, this shift expands the range of non-formal learning environments in which the young and the older generations come together in shared spaces and learn together and from each other, which is recognized in the literature as 'mutual learning'. For example, the focus in environmental education has shifted away from how young people can influence the knowledge of older people and now includes non-formal intergenerational learning activities such as 'community gardening' where the young and older people grow vegetables and 
fruit together in public and private spaces. This is opening up a new agenda of research on the benefits of intergenerational learning with an emphasis on the use of 'public spaces' as places where the young and the older generations can learn from each other to their mutual benefit.

\section{Social Capital Building, Empowerment and Intergenerational Learning}

Toward the end of the twentieth century, a new paradigm emerged that has further advanced the notion local and regional communities as a range of social contexts in which people from different generations work together towards common goals. As intergenerational learning becomes more culturally diverse and integrated within communities, their connection to the social capital paradigm becomes more evident. Though interpretations of social capital abound, the building of social capital consists of those aspects of social life that induce people to learn and act together. Intergenerational learning in such community learning environments represents non-formal and, in particular, informal learning processes of social capital building in which the generations are working towards common community goals. These non-formal and informal learning activities in both urban and rural areas relate, for example, to co-operative activities in relation to the issues concerning the environment, housing and homelessness, health, care, transport, safety, derelict buildings, redundant industrial sites, and the management of public spaces such as squares, parks and gardens. The important products of intergenerational learning are regarded as producing outcomes in terms of social inclusion, cohesiveness, mutual trust and solidarity. Social capital initiatives are compatible with empowerment theory and intergenerational learning for community building. Empowerment within intergenerational learning is an intentional ongoing process centered in the local community involving mutual respect, critical reflection, caring and group participation through which people lacking an equal share of resources gain greater access to these resources. It is becoming more evident that intergenerational learning as the intergenerational exchange of knowledge and skills can contribute important learning outcomes both the younger and older generations in the knowledge society of the 21 st century. Outcomes measured in terms of the generation of the "social capital" of older people constitute a significant feature in recent research which can enable them to become active members of an intergenerational "learning society".

\section{INTERGENERATIONAL LEARNING IN URBAN GARDENS}

This chapter now turns to an examination the historic development of gardens in urban spaces together with the contemporary dimensions of the "community gardening' movement in terms of 'intergenerational learning'. Gardens can be also examined as urban spaces where intergenerational learning takes place. It will first of all examine some fundamental characteristics of gardens in urban space, and subsequently, it will examine the modalities of intergenerational learning in urban gardens. 


\section{Gardens in Urban Space}

Alternative approaches to the production and consumption of vegetables, fruit, and herbs have resulted in the increasing significance of gardening in urban spaces during the past decade. Urban gardens can involve a variety of features such balcony troughs, fruit parks and promenades, rooftop gardens and hedges instead of iron or concrete fences; all of these are used by self-organized groups in numerous countries around the world to renew and transform public spaces. On the one hand, urban gardening is a response to the all-too-obvious dangers to health posed by the consumption of high levels of sugar and salt contained in industriallyproduced 'fast foods', and indeed all 'processed foods'. On the other hand, 'urban gardening' is characterised by alternative forms of food production which are intimately linked with more informed patterns of producing and consuming food. Urban gardens represent economic, ecological, cultural and social challenges for the local population. On top of being a place for socializing, exchanges, interactions, self-sufficiency and learning, they also provide a social and cultural corrective, while simultaneously re-connecting life with the direct experience of providing for human needs.

It is important to identify different historical and contemporary forms of urban gardens. Historically, the 'allotment' or 'garden plot' has been the dominant form of urban gardening. Allotments comprise small areas of land tended by individual tenants and their families to produce food for their own consumption. In the case of 'urban farming', however, produce is grown by individual tenants, or owners, of 'market gardens', which source local food markets on a 'for-profit basis'. A 'community garden' can be defined as any piece of land gardened by a group of people with a focus on a community-based understanding of the social relationships between the production and consumption of food. There are, however, different types of community gardens as physical and social spaces. They can be spaces, for example, where the entire area is tended collectively for common use. However, community gardens can also source non-profit 'food banks' including the weekly distribution of 'food baskets' for poorer local inhabitants. A variation upon this theme is the 'pick-it' community garden where local inhabitants are encouraged to pick and consume the crops grown by others. However, community gardens can also provide an open space offering opportunities for recreation, exercise, and education while also functioning as therapeutic and healing centres for people with mental and physical disabilities. The common thread is that these different types of community garden are actively maintained by the gardeners themselves for the benefit of local communities. Variations among urban gardens are influenced by different interpretations of both 'community' and 'gardens' in urban spaces. Urban gardens are valuable resources in neighbourhoods and they can transform derelict spaces such as public parks, old factories, vacant building sites, etc. At the intersection of notions of community and garden there are key issues of enclosure, inclusion and exclusion. 


\section{Historical Roots of Urban Gardens as 'Learning Spaces'}

While adult educators frequently refer to 'learning environments' and 'learning places', they do so with a metaphorical use of 'space', and they have largely ignored the very real spatial location of learning in both rural and urban spaces. This has resulted in a failure to analyse how the programmatic concepts of adult learning practices and their intended audiences were closely related to their specific spatial locations in urban settings together with the crucial role of local spatial processes for the social organization of these practices in urban areas. Given the so-called very recent 'spatial turn' in studies of adult education, this section of the paper departs form the mere metaphorical use of the 'places of knowledge' and will instead attempt to elucidate the fundamental significance of 'real spaces' for the dissemination and acquisition of knowledge, skills and sensitivities in the context of 'urban adult education' practices.

Adult educators have above all largely ignored gardens as 'learning environments' in the broader landscape of formal, non-formal and informal (adult) learning in urban spaces. The literature on the history of adult learning makes only scattered references to the role of botanical gardens and municipal parks as part of the popularization of botanical and horticultural knowledge from the eighteenth century onwards. There has been a marked lack of interest in the development of the long-standing tradition of 'allotments' for the working class. From the midnineteenth century onwards, allotments in urban areas manifested a European-wide movement and were known as 'jardins ouvriers', 'Schrebergarten', 'volkstuinen', etc. They were a consequence of industrialization and urbanization during this period of European modernization. Rural populations migrated to towns and cities to find employment and a 'better' life. However, urban working-class families lived under extremely poor conditions with exploitative wages, poor housing, malnutrition, bad health and low life expectancy. In response to the 'social question' posed by the volatile urban working class, philanthropic employers, the churches and local authorities provided open spaces for gardens so that the 'working poor' could grow their own food. Historically allotments have been characterized by social, economic and cultural vulnerability, conflict, and political contestation. Allotments have always been located at a significant distance from 'enlightened' urban spaces such as 'botanical gardens' for the popularization of science, and the gentile middles-class sociability of walks in urban parks in wellto-do city centres. Urban-gardening for the workers was largely located in the margins of industrial cities along railway lines, roads, streams and canals, derelict sites surrounding factories, and, vacant building plots.

'Allotments' were embedded in a social ethic that espoused industriousness, sobriety, respectability, and independence. To the surprise of social reformers, workingmen and their families adopted allotment schemes as their own with enthusiasm and dedication. Individual gardeners rapidly organized themselves in self-organized allotment associations. Allotments throughout Europe were transformed into 'the practice of democracy'. Local allotment associations provided the working class with an unparalleled opportunity for grassroots political 
participation and gave way to a marked increase in working-class political awareness in many countries.

From the late nineteenth century to the end of the First World War, an overwhelming increase in allotment cultivation was obvious throughout Europe including the Baltic, Central European and Balkan countries. Urban food production became a permanent feature of the lives of many workers and their families. Food production within urban areas, especially fruit and vegetable production in allotments and home gardens, became essential for survival especially in periods of food shortages caused by military conflicts, which resulted in black markets for food and exploitative prices. These phenomena were replicated throughout Europe and were enhanced by the Great Depression, and the Second World War.

Following the Second World War, patterns of working-class participation in allotment gardening significantly diverged in Western and Eastern Europe. In Western European countries, the increasing availability of mass-produced foodstuffs, especially processed foods together with refrigeration, reduced the dependence of the working class upon their own efforts to produce vegetables and fruit. Allotments became increasingly unused, vacant plots became derelict, or they were turned into urban spaces for family recreation rather than production. Since the late $1950 \mathrm{~s}$, there has been a major historical shift towards the cultural use of allotments as recreational spaces and locations for social gatherings for families and friends. This often added open space to insufficient family housing in crowded inner-city areas.

Under the communist regimes in Baltic, Central and Balkan Europe, however, there was a marked persistence in the use of allotments to produce food which reflected the efforts of families to be self-sufficient in the face of systematic food shortages. Moreover, there was also an increase in participation in the informal economy of self-sufficiency among those with 'party privileges' and access to land, known as the 'Dacha economy'. The utilization of urban land for food production remained a major household activity until the collapse of communist regimes in 1989. As such, the large-scale urban gardening practised in Central and Eastern Europe raises interesting questions. The key question is how household economies have changed between the communist and post-communist periods. What is the impact upon the persistence of urban gardening as an economic need, or as recreation in 'transition economies'?

Since the mid-1990s, urban gardening for food self-sufficiency has returned to the activities of many families, communities and social movements throughout Europe. In many countries, there are now long waiting-lists for allotments, and community gardens and urban farming are increasingly significant on the sustainable development agenda at national, regional and local levels. Given the ongoing economic crisis since 2008, the economic needs of households, together with mass unemployment, are impacting upon sourcing of food by households, and alternative forms of production and consumption in community-based gardening. There are now competing claims upon urban spaces. Existing urban allotments are threatened by market forces in many cities and towns. Derelict industrial sites and 
vacant building plots in urban areas are now 'contested spaces' in the struggle to establish community gardens. Illegal sowing of seeds in urban spaces, often at night, is now propagated as a political act by the 'guerilla gardening' movement. The politics of urban gardening today involve struggles between local activists, property developers and local authorities worldwide.

\section{MODALITIES OF 'URBAN GARDENS' AS INTERGENERATIONAL LEARNING SPACES}

Intergenerational learning involves different generations participating in a variety of 'learning environments' which involve the communication and acquisition of knowledge, skills and sensitivities. Understanding gardens as learning environments suggests that this involves 'urban learning spaces' that they are quite specific physical spaces where intergenerational learning can take place. However, these urban learning spaces are also 'real physical places' where the social organization of intergenerational learning is influenced by social, political and economic forces at the local level. They are 'real social spaces' for the communication and acquisition of knowledge, skills and sensitivities between generations. This learning can involve the development of 'trans-generational' subjectivities and identities at the interfaces between families, neighbourhoods, communities, and public institutions. Urban gardens can be intergenerational learning spaces which work to transform passive 'consumer' identities into active 'producer' identities. This opens up perspectives on the 'micro-politics' of intergenerational learning in terms of the development of inclusive 'citizenship' identities through self-organization of local and democratically organized communities.

It is possible to identify four modalities of urban gardens as potential 'urban learning spaces', and their different contributions to intergenerational learning. I make a distinction here between: a) family spaces; b) service-based spaces; c) shared-site spaces; and, d) contested spaces for intergenerational learning.

Urban allotments as family learning spaces largely involve older family members, such as parents and grandparents, in the intergenerational transfer of knowledge, skills and sensitivities to younger family members. Tenants demonstrate a surprising tenaciousness in continuing to cultivate their gardens and involve their families. Furthermore, allotment gardening is an activity largely passed on from one generation to the next within families. In a study carried out in Llubljana, for example, $88.6 \%$ of tenants come from families that long had an allotment and they were attached to these gardens since childhood. Successful family gardening, however, depends upon passing on knowledge, skills and sensitivities from generation to generation. This can involve informal intergenerational learning through watching, doing, talking and telling stories. Urban gardeners can also learn from each other and use other younger/older tenants as informal learning resources. However, knowledge and skills can become dissipated between generations. Gardeners' cultivation habits can become accommodated to 'fashionable' vegetables sold by global commercial providers. 
Given renewed interest in seasonal and local food, however, older generations may have retained knowledge about 'forgotten vegetables' and be 'seed banks' for younger gardeners.

Allotments offer urban residents with opportunities to unwind from stress, interact with other members of their families, and engage in physical activity. The contribution of gardening to a healthy and active life-style is increasingly recognized, especially for the elderly. Although allotments are becoming more diverse in their age, ethnic and socio-demographic composition, the majority of allotment gardeners in most countries are older people. Allotments can make a significant contribution to the intergenerational dimensions of the healthy aging agenda. Older allotment gardeners tend to score significantly better on all measures of health and well-being than non-gardeners of the same age. Greater health and well-being benefits of allotment gardening for older gardeners may be related to the finding that older gardeners are more oriented towards physical activity rather than passive relaxation.

Older allotment gardeners also gain a strong sense of achievement, satisfaction and aesthetic pleasure from their activities. Moreover, allotment movements throughout Europe have involved self-organization and 'the practice of democracy'. Allotment gardeners organize themselves in associations and pay a small membership fee. These are usually managed and run by the participants themselves through democratic processes of elections and establishing their own rules and regulations. Membership grants them democratic rights to determine the associational constitution, elect a committee, and be candidates. Allotments can be significant learning spaces for the development of citizenship. Gardening associations also play a role in the dissemination and acquisition of knowledge, skills and sensitivities through the organization of systematic non-formal and informal learning activities.

From the 1980s onwards, increasing emphasis has been placed upon urban gardens as service-based spaces for 'intergenerational learning programmes'. These programmes involve intergenerational learning activities initiated by public and private institutions in the fields of education, health, care and welfare services. This has contributed to the expansion of 'school gardens', where the learning undertaken by children is also intended to influence their parents and grandparents knowledge and behaviour with regard to 'healthy eating' habits. The 'slow food' school garden in Condotta in Italy, for example, is a school-based site for community gardening, where young people are taught how to grow vegetables and fruit by older people. There has also been a proliferation of 'organized gardening projects' which target 'at-risk' categories involving different generations. Such projects are often located in the grounds of local schools, hospitals, psychiatric care facilities, and residential and nursing homes for older people. This type of community gardening projects focuses on providing disadvantaged young people with opportunities to interact with older people as positive role models and mentors. Younger people are encouraged to benefit from participation in stable and supportive community environments, while older people are able to gain satisfaction from contributing to their local communities. 
These service-based community gardens are 'intergenerational learning spaces' which focus on therapeutic needs such as social contact, physical activity, mobility, health, eating habits, learning disabilities, rehabilitation, and alcohol and drug misuse. In most cases, they explore how relations with older members of local communities can help the young become more effectively integrated into society. They are informed by intergenerational learning activities in urban garden environments which support behavioural change among the young. As such, these urban gardens are based upon the service-based concept of measurable behavioural outcomes among young people. In the main, they do not focus on targeted outcomes for older participants. For example, findings from evaluations indicate that the project goals of service providers were different from the goals of older adults involved as 'mentors' and 'role models'. They look at gardening activities in terms of 'wellness', 'social capital' and 'community involvement' rather than behavioural change among the younger target groups.

Gardens as shared-site spaces for intergenerational learning primarily involve associational contexts in local communities where different generations can learn together, and from each other, in relation to shared concerns. Carlsson (2008) has emphasized this specific intergenerational form of community gardening. He argues that urban gardens provide space for "... unregulated social interaction", and that they are "... important arenas for the generation of multi-generational circuits of communication, memory, and experience" (Carlsson, 2008: 83). This involves bringing older and younger people together to work on common goals and shared solutions to community problems. Common concerns can be the management of public and cultural spaces such as parks, leisure venues, museums, and libraries, etc. The activities may facilitate discussion between older and younger people about what action should be taken - for example, forums to share points of views about different potential uses of public spaces - or can be more practical - for example, clearing wasteland and turning it into a community garden. Using community and public spaces for intergenerational learning also helps to ensure that community assets are used equally by all social groups. As well as developing solutions to local problems, these types of activities are intended to promote increased understanding between generations.

These non-formal learning environments include a very diverse range of gardening activities based upon voluntary participation in voluntary in associations, clubs, churches, hobbies and local heritage projects. Shared-sites can open up a new agenda for intergenerational learning with an emphasis on mixedgenerational housing, mutual caring, and safety in 'urban spaces', such as public parks, squares, and derelict sites. Such urban spaces are often poorly maintained, run-down, and regarded by older people as threatening places. Regeneration projects based on intergenerational community gardening can become urban spaces where the generations can learn from each other to their mutual benefit. Shared-site activities involving intergenerational learning can also link community gardens with community arts. This can include intergenerational learning through the plastic and performing arts including sculpture, photography, painting, film, dance, music, singing, and drama. 
The more than 50 Jardins Partagés (JP) [Neighbourhood Gardens] in Paris serve as another example. JPs are established and animated by local associations on small public plots of land made available by local authorities. The aim of the JPs is quite simply a '... way for people to get down in the dirt'. Through the creation of shared community spaces, they constitute social and cultural hubs, fostering a sense of community between different generations of local residents. They can be major players in the urban renewal agenda, improving environmental quality, as well as re-creating social life in their neighbourhood. Moreover, JPs frequently provide the stages for shows, parties, children's activities, opportunities to involve other citizens, especially 'older' neighbourhood residents. They often contribute to the community garden's life by donating plants, gardening tools and furniture, offering their knowledge and skills, and sharing their memories of the neighbourhood with younger generations.

Urban gardens can be become, however, contested spaces with a potential for intergenerational learning. The development of urban gardens as a space for selforganized knowledge, skills and sensitivities between the generations, whether in neighbourhoods, communities, action groups, and social movements, can bring them into conflict with other stakeholders such as local authorities, land-owners, property developers and other inhabitants. Non-formal and informal learning activities in urban spaces, for example, relate to co-operative activities in relation to issues concerning the environment, housing and homelessness, health, care, transport, safety, derelict buildings, redundant industrial sites, and public spaces such as squares, parks and gardens. Empowerment through intergenerational learning is a process centred in the local community involving mutual respect, critical reflection, caring and group participation through which people lacking an equal share of 'public' resources, such as space, struggle to gain or retain access to these resources.

In some cities there are ongoing struggles to retain long-standing urban gardens, resistance to designating new spaces for this purpose, and the occupation of derelict land for community gardening purposes. This necessarily involves community gardeners of all ages in processes of social capital building, empowerment, and political struggle with regard to legitimate claims on public and private resources such as land in urban spaces. The JPs in Paris have also become catalyzing places for intergenerational participation in public life at the neighbourhood level. They host debates around local issues and stimulate people to re-appropriate their public awareness and commitment to self-organization. Sometimes, the political connotation is obvious and the JP can become a 'hard' space for social mobilization to retain public green spaces and reclaim derelict land. This can also lead to direct action on the streets to address the needs of older people in the local community who are less mobile, sometimes homeless, and often seek shelter in community gardens. Community gardens can also involve intergenerational activities involved in the empowerment of those from different generations who share sexual orientations such as lesbian, gay, bisexual and transgendered action groups. 


\section{CONCLUSION: WHAT IS GROWING IN URBAN GARDENS?}

This paper has explored the history of urban gardening in terms of how intergenerational learning in a variety of urban gardens contributes to individual and social transformation. From the early 19th century onwards, urban gardens have been significant intergenerational learning spaces for the dissemination and acquisition of knowledge, skills and sensitivities. This remains the case today. A great deal of learning takes place in urban gardens. This can involve the dissemination and acquisition of knowledge, skills and sensitivities associated with the individual and collective activities involved in the production and consumption of food. This learning is not limited to the techniques of tilling the soil, sowing and tending for plants, but also includes learning about the active role citizens can play in producing food rather than being the passive consumers of global capitalist products. Furthermore, urban gardening can also contribute to the acquisition of more diffuse competences such as personal development, a sense of well-being, social capital and community involvement. This can include acquiring the knowledge, skills and sensitivities appropriate to the trans-generational citizenship involved in running a community-based democratic organization.

Community gardens are increasingly becoming spaces for political contestation. Competition for use of urban space for gardening, housing and office buildings has emerged as a major problem, and this has been enhanced by the ongoing economic crisis. Analysis of the use of urban land highlights the significance of politics for grassroots organizations within a market-centric, neo-liberal economic framework. This involves garden advocates of all ages in action to raise the scope of these controversies beyond the scale of individual plots and community gardens to the city level, and beyond to the democratic organization of the state itself. An appropriate motto might be "If you can dig it, learn from it".

\section{REFERENCES}

Newman, S., \& Hatton-Yeo, A. (2008). Intergenerational learning and the contributions of older people. Ageing Horizons, 8, 31-39.

Schmidt, B., \& Tippelt, R. (2009). Bildung Älterer und intergeneratives Lernen (Education of elderly and intergenerational learning). Zeitschrift für Pädagogik, 55(1), 74-90.

Barry Hake

Department of Learning in Organisations, School of Education

Leiden University

The Netherlands 


\section{INTERGENERATIONAL LEARNING IN DIFFERENT CONTEXTS}

\section{INTRODUCTION}

The current demographic trends that change the relationship between the generations and that, consequentially, influence life in the social, economic, cultural and political fields, dictate the need for stronger intergenerational ties and a reduction in age segregation. Even though the number and variety of intergenerational programmes has lately been on the rise, experts warn that programmes that merely focus on intergenerational concerns cannot bring about the necessary changes to societal norms, points of view, institutions and practices. The welfare of all generations within the community can be improved only through coordinated endeavours among of all sectors: social, economic and cultural (Henkin, 2007: 148). The implementation of such communities should start from the belief that the aging population opens new opportunities for numerous people who otherwise think and function differently, but who are united in the common goal of benefiting the community and its human and natural resources. The starting point for a successful implementation lies in changing the community members' perceptions about community education and intergenerational learning.

\section{RATIONALES FOR INTERGENERATIONAL LEARNING}

For centuries, an important part of intergenerational learning and the occasional transfer of knowledge, skills, competencies, norms and values between generations, have occurred within families. In these types of learning situations, the grandparents shared their wisdom and experience with the younger family members; they were respected due to their preservation of the values, culture and uniqueness of the family (Hoff, 2007). However, today the spatial separation of the nuclear family from its expanded counterpart results in fewer opportunities for intergenerational learning and support, and this makes the young and old increasingly vulnerable. An increasing number of young people have rare contact with the older members of their families, who could - with their experience and wisdom - offer support to the younger family members while they are growing up and learning. Due to the ever-rarer contacts with their younger family members, the grandparents are also deprived of the direct link to contemporary social events and new technologies as well as the vitality and the sense of belonging that they would receive from their younger family members if they lived physically closer. Both groups are losing reliable support that can be offered by family members from opposite ends of the life continuum. Therefore, individual authors (e.g. 
Newman \& Hatton-Yeo, 2008; Hatton-Yeo, 2007) have drawn attention to the appearance of a new, non-family paradigm of intergenerational learning, which is a consequence of demographic, social and economic changes. Due to the potential threat of intergenerational conflicts, based on an aging population and tougher economic conditions, it is necessary to create opportunities for intergenerational learning that would include non-biologically linked children, youth and elderly. Scholars in the field of humanities, and especially economists, are drawing attention to the problem of distributing economic welfare amongst the various generations (Asheim \& Tungodden, 2004; Campbell, 2009). Politicians are aware of this; thus, over the past few years, they have been busy adapting various strategies and writing public reports about the necessity of intergenerational cooperation and harmony. To experts, the solution to this threat of intergenerational intolerance and the egoism of the individual generations lies in the development of intergenerational community programmes in which the emphasis would be placed on educational content.

Intergenerational debates often emerge from two theoretical perspectives, i.e. the theory of realistic conflicts and the theory of social identity. The theory of realistic conflicts (Sherif, 1966) is based on the thesis that conflicts between groups arise from competition between the groups. Conflicts emerge between the groups if the groups have contradicting goals, or when the achievement of the goals of two or more groups excludes the achievements of the other groups. Through studying the interactions between groups, Sherif has ascertained that the conflicts can be reduced or even avoided if the groups have a common goal. The opinions and beliefs that the members of a certain group hold towards other groups will most likely improve if all of the group members would strive for a common goal, for this will reveal the previously 'unknown' qualities of the other group members, which will, in turn, lead to cooperation and harmony between the groups. These conclusions are in concordance with the starting points of the intergenerational programmes in which various age groups cooperate in order to find solutions to the common problems that arise in their neighbourhoods and attempt to fulfil their common goals.

The idea of the theory of realistic conflicts was expanded with the theory of social identity. This theory addressed the contents (perceptions, thoughts, revelations, etc.) that emerge, due to life in a group, as a consequence of the interactions and communication within the group. As the architect of the theory of social identity, Tajfel (1981) took the studies of divisions between groups as a starting point. In the most commonly quoted work, Tajfel and Turner (1986) presented the integral theory of conflicts between groups. The theory of social identity arises from the personal and social identity; the personal identity is linked to the way in which we perceive ourselves in comparison to others within a certain group (e.g. an individual in comparison to his/her peers), while the social identity is the result of the comparisons between various groups within society (e.g. between the young and the elderly). These comparisons emerge from our perceptions of relevant social groups, which are views that are portrayed by the media and which are reinforced by various social stereotypes. Abrams and Giles 
(1999) have drawn attention to the problem of communication in intergenerational programmes. This problem emerges due to the stereotypes (between the members of the various age groups) and because the qualities of the individual are not taken into account.

The theory of social identity assumes that people categorise others into groups in order to simplify the complex information and the social environment that surrounds them. Our opinions and perception of others are simplified, which means that we group them (e.g. all young people are the same), and at the same time position them, in opposition to ourselves (e.g. the young and the old have nothing in common) to a greater extent than is true. When we identify ourselves with a social group, we are automatically comparing the different groups. The consequence of those comparisons influences the way we perceive ourselves as well as our reactions towards people who belong to other groups. According to Vec (2007: 80), social identity usually places the individual in relation to social categories, positions or statuses. In accordance with the theory of social identity, the stereotypical age differentiation between the participants of intergenerational programmes can be avoided by emphasising the individual qualities of the participants. This is especially important because intergenerational programmes are based on the participants' shared interests, such as for instance improving the quality of life in the neighbourhood.

The social identity theory supposes that the power relationships between social groups are often disproportionate and that these groups compete for position and power. In regard to that discussion, Garstka et al. (2005) stressed that if we begin with age categories (such as young adults, middle-aged adults and older adults) we can assume that intergenerational relationships include the same battle for preserving a high social status or for improving a low social status. The belief that the young and the old have a lower social status than middle-aged adults was confirmed by the results from the research on status differences as regards to power, influence, respect, health and reputation (Garstka et al., 2005: 322). The young and the old, therefore, feel that power is unequally divided between the generations and they also feel that they are discriminated against due to their age when compared to middle-aged adults.

\section{CHARACTERISTICS OF INTERGENERATIONAL LEARNING}

Intergenerational learning programmes can emerge from various institutions and appear in various forms, e.g. in schools, community organisations, hospitals and elsewhere. If traditional teaching and learning in various forms of social life (family, school, clubs, workplace) are mainly set so that the young learn from older adults, intergenerational learning is based on reciprocity and cooperation, which can be variously intense. Kaplan (2002) has noted that intergenerational programmes are a continuum of intergenerational inclusion - from initiatives that do not demand a direct contact between the age groups, to initiatives that encourage intense contacts and constant and long-lasting possibilities for confidentiality. Each of the levels has its own meaning and role within the 
intergenerational learning programmes; however, it is important that the activities that encourage different types of inclusion between the generations build upon one another and intertwine.

The new paradigm of intergenerational learning is connected with the concept of community education. Authors have connected community education with such terms as active participation for the common good, social and collaborative learning, empowerment, community renewal, solidarity and social equity, cohesiveness and inclusion, active citizenship, and social capital (Allen et al., 1987; Brookfield, 1983; Hamilton, 1992; Poster \& Krüger, 1990; Longo, 2007; Tett, 2006; Thompson, 2002). This type of education enables people of all ages to satisfy their interests and to meet their needs in the most relevant manner. The aim of community education, with its important social functions, is to work together for mutually beneficial development and a higher quality of life in the community. Community education comes to the forefront especially during poor economic situations, for it has always endeavoured to achieve positive social changes in which the members of the community would grow personally and improve their lives and interpersonal relationships. Community education erases the borders between the more traditional possibilities of education that take place in formal education institutions and the possibilities of informal education in voluntary associations and study groups; it takes place at various locations and in various forms (English, 2005).

Intergenerational learning programmes are defined as planned activities that intentionally link various generations with the goal of sharing their experience and achieving mutual benefits (Newman \& Hatton-Yeo, 2008; Hatton-Yeo, 2007). They could be denoted as 'a social mechanism that creates a meaning and constant exchange of sources and learning between the older and younger generations' (Kaplan, 2002: 306). The goal is to establish ties between the young and the old with the hope that one or both groups will benefit. This can take the form of the young helping the elderly, the elderly helping the young or reciprocal intergenerational help or learning.

Intergenerational learning programmes have an influence upon the programme participants as well as the broader environment (i.e. local community). Different researchers (Fried et al., 2004; Goff, 2004; Kaplan, 2002; MacCallum et al., 2006, etc.) have analysed the effects that intergenerational programmes have on individuals as well as the community. Youth gain knowledge and skills (including social skills), grow emotionally, learn about team work, and develop the capability for empathy, creativity, initiative and openness. The elderly are also positively influenced by intergenerational learning; these programmes influence their health and their level of activity and their views of the younger generation. Moreover, the symptoms of depression were significantly reduced amongst the older adults who participated in intergenerational programmes and their mobility and their ability to solve problems increased. Apart from this, the elderly also felt respected and received recognition for the contributions they made to the community as well as acknowledgment of their past experience and achievements. 
The goal of numerous intergenerational programmes was primarily oriented towards increasing the quality of community life (for example, to preserve the local history, create folk art and culture, encourage a clean environment or to encourage community learning [Kaplan, 2002: 313]). The effects can be seen in various aspects of community life and are shown, for instance, in the members of the community taking responsibility, reducing stereotypes, reviving contacts between neighbours and relatives, encouraging social cohesion and establishing a more inclusive society. The goals are also oriented towards forming social networks and strengthening community ties, revitalising the public infrastructure within the community and developing volunteer opportunities.

Regardless of the numerous positive examples of intergenerational learning and cooperation, the influence of the programmes has to be considered critically and with great attention. Great expectations exist that the intergenerational programmes will have outstanding positive effects on the lives of children, youth and adults. However, researchers have been ascertaining that there are numerous obstacles for a systematic development of intergenerational programmes, e.g. traditional age segregation of the participants in the study groups, lack of cooperation between the financial funds on local and national levels, insufficient inclusion of programmes into the existing job system, and insufficient system for ascertaining and exchanging experience and good practice (Kaplan, 2002: 327), to state just a few.

\section{SOME RESEARCH FINDINGS FROM SLOVENIA}

\section{Slovenian Context}

Slovenia is situated in Central Europe, and borders Italy, Austria, Hungary, and Croatia. It has been a member state of the European Union since 2004 and joined the OECD in 2010. Slovenia has a population of 2.05 million, and is among the European countries with the most pronounced aging of the population, ascribable to a low birth rate and increasing life expectancy. According to Eurostat's EUROPOP2010 (Eurostat, 2011) population projections for the next 50 years, the age structure of the population will soon shift significantly. In 2010, older adults (aged 65-plus) represented $16.5 \%$ of the population, but in 2060 almost every third person in Slovenia will belong to this age group.

Almost 300,000 people (15\%) have everyday experiences with complex intergenerational relationships, as they live in family households with at least one member of the first generation and at least one member of the third (or even fourth) generation (SORS, 2013). There are only 1,186 households with all four successive generations. Three-generation households are most frequently composed of grandparents and a married son/daughter with children. Another rather common type of three-generation household is a single-parent family (son/daughter with children) living in the same household with his/her parents and their family. The number of households consisting of both a grandparent and a grandchild was 2,993 (SORS, 2011). 
Traditional intergenerational solidarity in Slovenia remains an important form of social support despite (post)modern societal and familial changes. In light of the decreasing size of the family, it is important to note that this is not limited to close family and, in terms of longevity, not limited to two generations. The data from several international surveys (EUROFAMCARE - European Family Care, SHARE - Survey of Health, Ageing and Retirement in Europe, EVS - European Value Survey, EQLS - European Quality of Life Survey) show that, in Slovenia, intergenerational exchanges and solidarity are more important within families than they are within other social support networks (Hlebec et al., 2012). The statements of Slovenian respondents on intergenerational solidarity are ranked in the middle, with the Mediterranean states on one side and Central and Northern Europe on the other, although there seem to be some more similarities with the Southern European familiastic value system. Family members exchange functional intergenerational support, especially support in the case of illness, and financial and practical aid. The quality and quantity of intergenerational support exchanges is mediated by the emotional quality of relations, ambivalence, and mutual expectations, as revealed by both the quantitative and qualitative data (Hlebec et al., 2012).

\section{Research Results on Intergenerational Learning in Different Contexts}

Data collection took place within the research project entitled 'Intergenerational solidarity in Slovenia' (Hlebec et al., 2012). In the framework of this project, we've conducted interdisciplinary field research that focused on the macro, mezzo and micro aspects of intergenerational solidarity in Slovenia. For the intent of the research presented in this book, we have focused on the micro level; we've used indepth semi-structured interviews to gather responses from students, their parents and grandparents regarding issues linked to community activities, intergenerational cooperation and learning, the social identity of the various age groups, and also learning between generations in the family. The sample included 23 families and the questions were answered by 69 participants.

In the analysis, we ascertained that the social changes that are reflected at the local level influence changes in the cohesion of the communities. The interviewees state alienation, poor informing and the disintegration of community values opinions that are based on stereotypes and the lack of connections between the generations and age cohorts - as the consequence and reasons for the perceived (and most likely also for the actual) lack of intergenerational activities in the local environment. Interviewees of the third generation who remember community activities in the past are of the opinion that the members of the community cooperated better in the past, because people were more connected (due to the community work) and they were more likely to socialise at home or at community events (joint actions, socialising, reciprocal solidarity and help as well as better communication between the young and the old). Interviewees regret the poor intergenerational cooperation. We can also ascertain that most of the interviewees explicitly distinguished between the role of intergenerational learning and 
cooperation within the family and within the community. The interviewees of all three generations are of the opinion that intergenerational cooperation within the family is good and that they learn and help each other. However, their opinion of intergenerational learning within the community is entirely different. Most of the interviewees, regardless of age, are of the opinion that there is almost no intergenerational cooperation and learning.

The analysis shows that the interviewees experience old age as an important characteristic of social categorisation and exclusion. This holds true regardless of the respondent's age or living habitat (village, suburb or town). To a great extent, the analysis of the interviews confirms that age is a factor in the social placement of an individual. Social categorisation emphasises the individual's belonging to a certain group. All the interviewees agree that the young and the old are separated as regards their social identities, they have no true connections amongst the various age groups, and the interaction between the members of the various age groups is poor. Members of the various age groups also estimate that the possibilities for intergenerational cooperation are slim in their environment. All agree that, in most cases, the age groups function independently of each other. When defining the differences between the age categories, social categorisation and the embedded opinion that the youth and the elderly have different interests, capabilities and characteristics is typical for Slovenia, and this presents a strong divide between the two groups. The data research shows (Kurdija et al., 2008) that the feeling of separation experienced by individual age groups does not necessarily mean disrespect of the various age groups, or that their opinions are not taken into account. The data indicates that most of the included respondents in Slovenia have positive feelings towards people who are 70 or older (almost $50 \%$ of the respondents have extremely positive feelings). Approximately $80 \%$ of the respondents who were questioned believe that most people in Slovenia perceive people over 70 years of age as individuals who deserve respect. They consider the influence that older people have on the habits and lifestyle of Slovenes to be important, and most of them consider this influence as being good or even extremely good. The fact that there are differences between the age groups is shown by the data from the European research (Flash Eurobarometer, 2009) in which $69 \%$ of the respondents in the EU stated that it is hard for the young and the old to agree as to what is good for society. ${ }^{1}$ In Slovenia, the percentage of respondents who agree with this statement is slightly lower (59\%).

From the case studies analyses in families, we can comprehend the association between the frequency of contacts, communication and intensity of relationships between three generations and the transmission of values and reciprocal learning in the family. In the case of the family with strong connections between the members of three generations, mutual help is understood as something obligatory. In such a network, a strong family network and a high level of trust reduce the need for organised education. In her research, Strawn (2003) has found that people with a strongly knit family network are involved in occasional and informal learning inside this network and they usually do not search for educational possibilities in the community. Our findings in strongly knit and closed families confirm these 
results; family members are not interested in involvement in any kind of learning settings in the community; on the other hand, they report about mutual learning between three generations in the family. In open families that are connected to the community, interaction is intensive and learning goes both-ways. The exception is the case of a relationally unconnected family, where communication is extremely weak and mutual learning between family members is limited.

In selected cases, we can see the connection between the relational closeness, inclusion in the social environment and the mutuality of help, cooperation and learning in the family. Mutual learning in the family is closely related to interaction, communication and the quality of relationships in the family. Analyses of the interviews show that, in most families, the third generation transmits values, such as honesty, perseverance, diligence, respectfulness, truthfulness, thriftiness and preservation of family tradition, as well as practical, useful knowledge and skills, like cooking, handcrafts and educational advice, to the younger generations. Quite a number of the interviewees from the second and third generations are of the opinion that they don't learn from their younger relatives, and they don't adopt their values. In contrast, other interviewees state that the younger generations give them joy and a sense of optimism; they also teach them sincerity, kindness and fearlessness, as well as practical things. Those are implicit learning processes that occur spontaneously every day during work and conversation, by modelling or demonstration. In the analysed cases, a lot of occasional learning is going on, which could be explained by the theories of situated everyday practice (Lave, 2009). We have noticed that in families where open communication, cooperation, mutual help and learning are present, the third generation accepts their position as positive (they are important, respected, family glue); in the families where cooperation and intergenerational help and learning is weak, older members explain their situation with ironic and bitter statements; for example: "I'm a housewife and nothing more." Some of the interviewees (third generation) warn about the troubles in intergenerational understanding and communication. In the opinion of the first and second generations, periodic conflicts might be the result of the different life principles that are held by each of the three generations.

Most of our respondents stated that they would be willing to enter into an intergenerational activity. The responses to this question also reveal the (stereotypical) views the individuals have towards learning as well as their understanding of how intergenerational learning is carried out. We assume that the stereotypical understanding of learning is a consequence of the past (often negative) experience with education, which even today mainly takes place in educational facilities and in the form of transferring knowledge from the teacher to the pupil; as such, it is usually connected to memorising, grading and, consequently, with the experience of success or failure. We also assume that the lack of possibilities for community education that would deal with the problems found in real life (problems experienced by everybody living in a certain community) influences the misunderstanding of the meaning of intergenerational learning and leads to poorer conditions for introducing these activities. The data from Slovene Public Opinion Research (Kurdija et al., 2006) shows that numerous 
adults in Slovenia do not link the activities that take place in community organisations with the opportunity for learning. On the basis of this data, we could conclude that other factors (such as education and age) also influence people's perceptions of their learning opportunities and their participation in intergenerational learning activities. In our research, the interviewees stated that there were quite a lot of associations and clubs in their community; for instance, the pensioner's club, the bee keeping club, the association of farming women and girls, etc., that organise educational activities (lectures, study circles, etc.); however, in their opinion there is a lack of planned activities that would bring the generations closer together.

\section{CONCLUSIONS}

Regardless of the perception that connections between the generations are weak, most interviewees remained open to different relationship and cooperation between the intergenerational groups. The opinion that an external community initiative would be necessary seems to be quite common.

Our research was conducted in 2009 and 2010; however, from that point on the paradigm of intergenerational learning has become much more recognized in Slovenia, which is most likely the result of the EU initiatives to foster intergenerational learning. Consequently, the Strategy for Quality Ageing and Intergenerational Solidarity (2011-2015) was adopted in Slovenia; in addition to goals connected with improving the quality of life for older adults, the development of a framework for intergenerational cooperation and learning is emphasised. This concern is devoted to local community development and the cooperation between different subjects at that level. In Slovenia, this has resulted in the intensive development of intergenerational community learning centres and networks of intergenerational learning programmes organised by the Anton Trstenjak Institute of Gerontology and Intergenerational Relations, Slovene Philanthropy, the University of the Third Age, the Slovenian Social Gerontology Association, the Association of Adult Education Centres, the Institute for Intergenerational Cooperation-Ypsilon, and also many civil society associations, schools, kindergartens, homes for older people, libraries, etc.

However, the fast development of intergenerational learning programmes in the community raises questions about the quality and the heterogeneity of the offerings. We don't have any overall data on the offerings; we don't know how the intergenerational learning programmes are being spread among different regions and local areas, but we also don't know how successful those programmes have been in responding to the various needs and interests of different age groups. These issues should be analysed in further research. 


\section{NOTE}

1 Younger members (under 25) were more likely to believe that it is hard to reach concordance amongst the young and the old. No differences were shown between the respondents who lived in a city, town or rural environment.

\section{REFERENCES}

Allen, G., Bastiani, J., Martin, I., \& Richards, K. (Eds.). (1987). Community education: An agenda for educational reform. Milton Keynes: Open University Press.

Abrams, J., \& Howard, G. (1999). Intergenerational contact as intergroup communication. Child \& Youth Services, 20(1/2), 203-217.

Asheim, G. B., \& Tungodden, B. (2004). Resolving distributional conflicts between generations. Economic Theory, 24(3), 221-230.

Brookfield, S. D. (1983). Adult learning, adult education and the community. Milton Keynes: Open University Press.

Campbell, A. L. (2009). Is the economic crisis driving wedges between young and old? Rich and poor? Generations - Journal of the American Society on Ageing, 33(3), 47-53.

English, L. M. (2005). International encyclopedia of adult education. Hampshire, New York: Palgrave Macmillan.

Eurostat. (2011). Population projections for Slovenia (2010-2060 - Final Data). Retrieved from: http://www.stat.si/eng/novica_prikazi.aspx?id=3989

Flash Eurobarometer. (2009). Intergenerational solidarity. Analytical report. Accessed 16/9/14 from: http://ec.europa.eu/public_opinion/index en.htm

Fried, L. P., Carlson, C. M., Freedman, M., Frick, K. D., Glass, T. A., Hill, J., McGill, S., Rebok, G. W., Seeman, T., Tielsch, J., Wasik, B. A., \& Zeger, S. (2004). A social model for health promotion for an ageing population: Initial evidence on the experience corps model. Journal of Urban Health, Bulletin of the New York Academy of Medicine, 81(8), 64-78.

Garstka, T. A., Hummert, M. L., \& Branscombe, N. R. (2005). Perceiving age discrimination in response to intergenerational inequity. Journal of Social Issues, 61(2), 321-342.

Goff, K. (2004). Senior to senior: Living lessons. Educational Gerontology, 30(3), 205-217.

Hamilton, E. (1992). Adult education for community development. New York: Greenwood Press.

Hatton-Yeo, A. (2007). Intergenerational practice: Active participation across the generations. Stoke on Trent: Beth Johnson Foundation.

Henkin, N. (2007). Communities for All Ages: A practical model. In M. Sánchez, D. M. Butts, A. Hatton-Yeo, N. A. Henkin, S. E. Jarrott, M. S. Kaplan, A. Martínez, S. Newman, S. Pinazo, J. Sáez, \& A. P. Weintraub (Eds.), Intergenerational programmes. Towards a society for all ages (pp. 147166). Barcelona: The "la Caixa" Foundation.

Hlebec, V., Filipovič Hrast, M., Kump, S., Jelenc Krašovec, S., Pahor, M., \& Domajnko, B. (2012). Medgeneracijska solidarnost $v$ Sloveniji. Ljubljana: Faculty of Social Sciences.

Hoff, A. (2007). Intergenerational learning as an adaptation strategy in ageing knowledge societies. In European Commission (Ed.), Education, employment, Europe (pp. 126-129). Warsaw: National Contact Point for Research Programmes of the European Union.

Kaplan, M. S. (2002). Intergenerational programs in schools: Considerations of form and function. International Review of Education, 48(5), 305-334.

Kurdija, S., Malnar, B., Hafner Fink, M., Uhan, S., \& Štebe, J. (2006). Slovene public opinion 2006/1: European Social Survey. Ljubljana: Faculty of Social Sciences, Public Opinion and Mass Communication Research Centre. Accessed 16 September 2014 from: http://www.adp.fdv.unilj.si/opisi/sjm 061/

Kurdija, S., Malnar, B., Hafner Fink, M., Uhan, S., \& Štebe, J. (2008). Slovene Public Opinion 2008/2: 
European Social Survey. Ljubljana: Faculty of Social Sciences, Public Opinion and Mass Communication Research Centre. Accessed 16 September 2014 from: http://www.adp.fdv.unilj.si/opisi/sjm 082/

Lave, J. (2009). The practice of learning. In K. Illeris (Ed.), Contemporary theories of learning (pp. 200-208). London, New York: Routledge.

Longo, N. V. (2007). Why community matters: Connecting education with civil life. Albany: State University of New York Press.

MacCallum, J., Palmer, D., Wright, P., Cumming-Potvin, W., Northcote, J., Booker, M., \& Tero, C. (2006). Community building through intergenerational exchange programs. Australian Government Department of Families, Community Services and Indigenous Affairs: National Youth Affairs Research Scheme.

Newman, S., \& Hatton-Yeo, A. (2008). Intergenerational learning and the contributions of older people. Ageing Horizons, 8, 31-39.

Poster, C., \& Krüger, A. (Eds.). (1990). Community education in the Western world. London, New York: Routledge.

Sherif, M. (1966). In common predicament: Social psychology of intergroup conflict and cooperation. Boston: Houghton-Mifflin.

SORS - Statistical Office of the Republic of Slovenia. (2011). Households and families, Slovenia, 1. January 2011 - Final data. Accessed 16/9/14 from: http://www.stat.si/eng/novica_prikazi.aspx?id= 4029

SORS - Statistical Office of the Republic of Slovenia. (2013). International Day of Families 2013. Accessed 16/9/14 from: http://www.stat.si/eng/novica_prikazi.aspx?id=5476

Strawn, C. L. (2003). The influences of social capital on lifelong learning among adults who did not finish high school. Cambridge: NCSALL.

Tajfel, H. (1981). Human groups and social categories: Studies in social psychology. Cambridge: Cambridge University Press.

Tajfel, H., \& Turner, J. (1986). An integrative theory of intergroup relations. In S. Worchel \& W. Austin (Eds.), Psychology of intergroup relations (pp. 7-24). Monterey, CA: Brooks/Cole.

Tett, L. (2006). Community education: Lifelong learning and social inclusion (2nd ed.). Edinburgh: Dunedin Academic Press.

Thompson, J. (2002). Community education and neighbourhood renewal. Leicester: National Institute of Adult Continuing Education.

Vec, T. (2007). Teoriji socialne identitete in samokategorizacije (Theories of social identity and selfcategorization). Psihološka obzorja, 16(1), 75-89.

\section{Sonja Kump \\ Faculty of Arts \\ University of Ljubljana \\ Slovenia}

Sabina Jelenc Krašovec

Faculty of Arts

University of Ljubljana

Slovenia 



\section{OLDER ADULTS AS ACTIVE MEMBERS OF NON-GOVERNMENTAL ORGANISATIONS}

Today's world promotes the view that a country's development as well as the growth of democracy is contingent on an individual and on the individual's active participation in public life and in public affairs. Taking an active citizen's position in the matters of the public life of local communities or in the issues of its individual members, influencing public view and making it public forms the basis of any democratic and civil society. The National Strategy to Overcome Population Ageing Consequences, ${ }^{1}$ Lithuania's Progress Strategy Lithuania $2030^{2}$ stresses the insufficient attention in Lithuanian educational policy to the problems of education of older people, and that society is little aware of the importance of lifelong learning. Accessibility for older persons to participate in political, social, economic, and cultural activities should be maintained. The goal of the community's civic life and volunteering development is to encourage community members to act through non-governmental organisations, to strengthen the capacity of non-governmental organisations and to develop a strong philanthropic tradition. Therefore, the democratic principle of life is more and more often defined through democratic participation, especially through active participation in nongovernmental organisations (NGOs) functions.

\section{NON-GOVERNMENTAL ORGANISATIONS: DEFINITION AND FUNCTION}

Non-governmental organisations in their entirety are often described as the third sector of economy, which is characterized by the organisational form, independent from governmental and governing institutions, non-profit distribution principle, self-government and democratic decision-making, volunteering and serving public needs. The first sector, public sector embraces the Parliament, the Government, the Ministries and local authorities, institutions in districts, towns and areas, and budgetary institutions; the second - business sector encompasses all commercial structures: enterprises, firms and companies of all types (Žemaitaityte, 2007). Nongovernmental organisations take active part in life of the Lithuanian society, and in their diversity contribute to the construction of the open society and seek the following aims:

- represent citizens' needs ;

- promote the diversity of opinions;

- act as a force affecting politics;

- signal the increase of tensions in society;

- act as a mediator between the people, the market, and the state. 


\section{ŽEMAITAITYTE்}

According to Zanden (1990), non-governmental organisations are organisations which people choose freely, these organisations are built in reciprocal interest, and people come to these organisations for passing time, interacting with peers, for extending social aid, servicing themselves and others. Sills (1968) identifies three main features specific to volunteer organisations: 1) Voluntary organisations are created to protect common interests of their members; 2) membership in such an organisation is voluntary; 3 ) these organisations are not connected to the local state or governmental authorities. In his opinion, the NGOs perform the following important functions in society:

- They are a bridge between individuals and the government;

- They cultivate their members' organisational skills which are prized by the employers and make professional performance more successful in all areas;

- They let various representative groups participate in political sphere;

- They assist national governance structures.

Non-governmental organisations are often classified according to what their mission of function and their goal is. The main distinguishing feature of the NGOs is the nature of their activity. This may be an organisation whose activities are directed to meeting the needs of society members, this may be an organisation that brings together people who wish to work on goals important exclusively for themselves (Juozaitis \& Vilimienè, 2000).

Domarkas and Gineitienè (2000) define a non-governmental organisation as an organisation founded by citizens in their free will and that serves the interests of public groups - that is, non-profit nor seeking to take direct action in public services of the state. Hudson (1999) classifies non-governmental organisations according to the organisational functions, forms of management and sources of income. In his opinion NGOs may be of the following categories:

- Voluntary organisations, which carry out the social mission based on the values of society;

- Public service contractors and organisations functioning as a market-oriented non-profit enterprise, serving public purposes;

- Civic organisations representing the interests of their members;

- Non-governmental organisations implementing public policy.

According to the international classification of non-profit organisations (ICNPO) non-governmental organisations are classified according to their activity into organisations of: culture and recreation; education; research; health; social services; playgroups and nurseries, environment, development, employment and training, grant-making foundations, religion and international activities. ${ }^{3}$ Fung (2003) and Putman (2003) focus on three main functions of non-governmental organisations in a democratic society: representation and advocacy of society members, civic socialization and resistance, and power control. NGOs develop and indirectly promote civic attitudes, values (such as tolerance, confidence, respect), as well as encourage citizens to focus on emerging societal problems.

The NGO sector is often referred to as the foundation of civil society and the keystone of a democratic society, capable of linking the government, businesses and people who affect public institutions, this act encourages community to unite 
for common activities (Žemaitaitytè, 2007). The NGO sector is in constant selfinvention, it demonstrates readiness to take up novelty, to learn, to reflect upon a new reality, trying to act and adapt, willing and able to act creatively, to make decisions quickly, to be more flexible, capable of experimenting, able to tailor its programmes to suit the needs of diverse groups, it has become important and pivotal in growth of non-formal adult education, which in many countries is one of the most important signs of social progress. Jarvis (1996) points out that while education is a private event, people need to learn, and provision of such possibilities is a key function of non-governmental organisations (Žemaitaitytè, 2007). Unlike state institutions, NGOs tailor educational programmes for the needs of the target groups, use funds more effectively and successfully, gain learners' confidence and become a driving force in the society. Drucker (2009) points out that rapid growth in the number of older adults, especially in developed countries, brings along the growth of the need for continuous learning for adults, therefore the non-governmental organisation sector becomes one of the true "sectors of growth", assisting in change of society and in change of people.

\section{PARTICIPATION IN NGOS ACTIVITIES AS A MEANS OF ACTIVATING OLDER PEOPLE}

One of the most motivating goals of NGO activities is the understanding of organisation's aims and objectives. A person, cooperating with a non-governmental organisation, has to apprehend oneself as a member of this organisation. It is essential for the individual to be given a voice and that one's opinion is regarded. Another significant feature of motivation is the perception of self-importance; therefore, it is important to appreciate even minor work of each member, a work which may be indispensable for the function of the organisation. Thus learning in NGOs depends on motivation, dealing with important public issues and challenges, autonomy and self-control, experience as one of the learning sources. Since participation in NGOs functions stems from the personal initiative, volunteering and, therefore, is motivated, it allows the participants to join active non-formal learning and self-education (Žemaitaitytè, 2007). NGOs working in different countries and providing social, cultural or other societally attractive services to the public, aim to involve more people for the voluntary action. Volunteering for the older people provides an invaluable opportunity to share their professional expertise, to find spare time activities and to extend help to others.

While reviewing the Lithuanian citizens' participation in the work of nongovernmental organisations, mostly in voluntary activities, it could be stated that public involvement in these activities is growing constantly, but it is also necessary to mention that the systematic and comparative studies of public participation in such activity is still rare. Ilgius (1997) revealed that in 1997 the Lithuanian population did not have enough information about the Lithuanian nongovernmental organisations, since as many as $36 \%$ of the Lithuanian population were unable to name a single NGO operating in Lithuania, only $9 \%$ said that they are NGO members, $5 \%$ of the population were involved in volunteering, and $73 \%$ 


\section{ŽEMAITAITYTE்}

indicated that they had never worked with NGOs. In 2002, SIC Market Research surveyed Lithuanian citizens' attitude towards NGOs, which showed that NGOs visibility is growing, $54 \%$ indicated their familiarity with at least one NGO. The NGO that was mentioned the most is Caritas (23\%). ${ }^{4}$ In 2010, according to Euro barometer data, $12 \%$ of the population was involved in voluntary work in Lithuania $^{5}$ (Fig. 15.1).

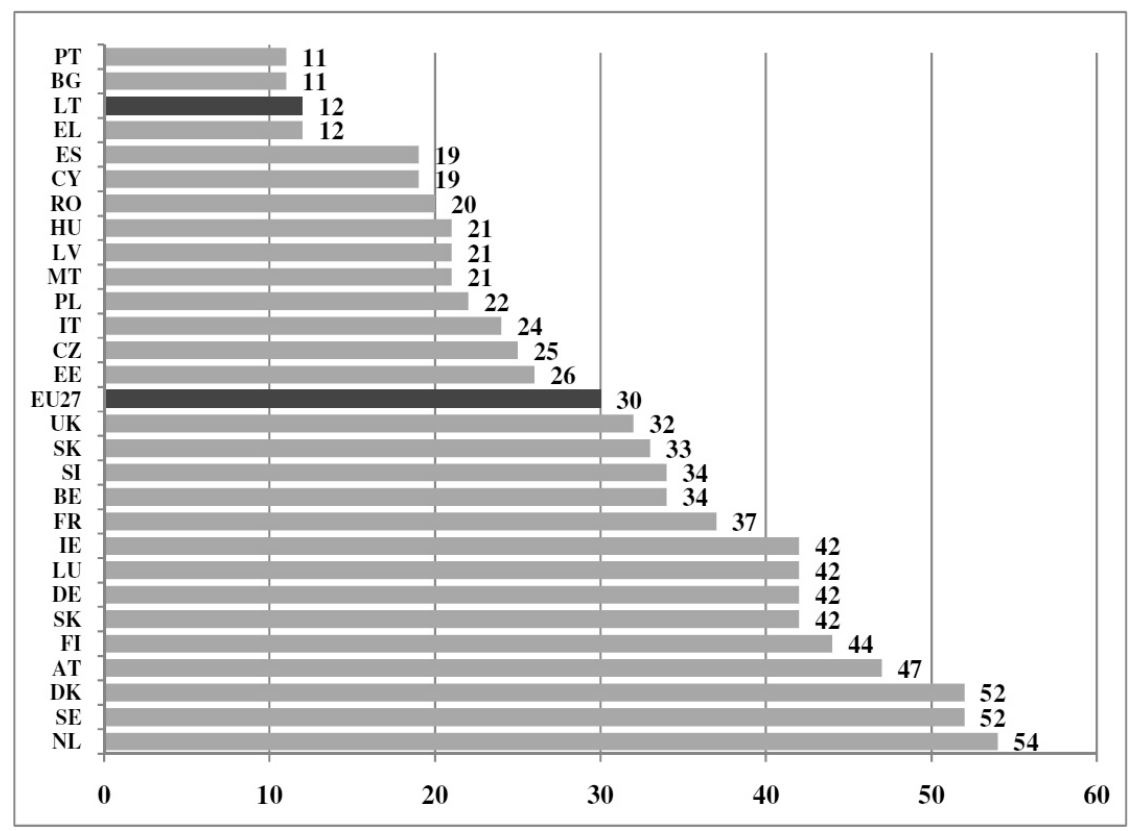

Figure 15.1. Active involvement in non-governmental organisations (\%). Source: Eurostat, undated. Statistics database.

In 2012 VILMORUS (Public Opinion and Market Research Centre) on the commission of the Non-Governmental Organisations Information and Support Centre conducted a representative survey of the population of Lithuania regarding NGO visibility and voluntary works ${ }^{6}(1,005$ respondents interviewed) which revealed that the majority of respondents $(71 \%)$ relate NGO activities with the help for others and charitable activities. Older respondents linked NGO function with organisation of free time. In response to the question about participation in voluntary activities less than one-fifth of the respondents indicated participating in voluntary activities, sadly, almost half of the respondents $(48 \%)$ admitted to not participating and having no intention to participate in voluntary activities. Among the reasons for not participating respondents indicated a lack of time (32\%), no encouragement $(22 \%)$, while $21 \%$ mentioned poor health or old age as the main 
obstacle. The later reason as the barrier for participation in voluntary work was mostly indicated by older people (70 years and older). In most cases respondents learned about non-governmental organisations, from television and press, older respondents usually mentioned the radio as a source of information about NGOs. When asked if they know where to enquire in case they wanted to get involved in the activities of NGOs $31 \%$ of respondents gave a positive answer. That gives reason to conclude that under more favourable conditions, Lithuanian citizens would take part in non-governmental organisations more actively. Currently, according to Registry Centre data, Lithuania has more than 32,000 nongovernmental non-profit organisations. The number of NGOs is growing every year, about 1,500 NGOs start their function (associations, charities and support funds, public enterprises). However, about 100 organisations are liquidated every year, many organisations cease to exist or transform themselves or become temporarily ineffective for different reasons. Yet, the growing and diverse list of NGOs including a great number of clubs, associations, unions, foundations, centres and other organisations, is a sign of a more democratic society.

\section{NGOS WORKING WITH OLDER PEOPLE - LITHUANIAN GOOD PRACTICE CASES}

\section{Lithuanian Retired Persons' Union "Bočiai”,}

After Lithuania regained its independence in 1990, Lithuanian people began joining various associations and organisations. In April 1991 a group of patriotically minded retired older citizens assembled and in 1992 founded the Lithuanian Union of Retired Persons called "Bočiai". 7 Currently, LRPU "Bočiai" connects 54 communities in Lithuanian cities, districts and municipalities, and possesses eight clubs which unite thousands of members. The main goals of LRPU "Bočiai" are to represent social, economic and cultural interests of the retired persons and persons awaiting retirement, to protect them at all levels of governmental institutions, to provide its members and the public with the information about the situation of older people in Lithuania and in the world, to organize discussions, conferences, seminars and to involve senior citizens into various cultural activities, to promote club activities according to the line of interests, to publish works, to participate in international projects, to develop healthy lifestyle, to self-help, to support and to deploy ethnic cultural traditions and to preserve the historical heritage. ${ }^{8}$ In 2004 LRPU "Bočiai" joined an international organisation, the European Older People's Platform and is actively involved in its activities.

The community sets particularly ambitious objectives for its cultural activities to organise cultural activities, of interest for older people, and to improve older people's way of life. The amateur art groups, craft groups, smart housekeepers' clubs are established. Older people involved in these groups not only make their own old age more meaningful, their days more diverse, but also attract other people of their age group. "Bočių" choirs, ensembles, dancing and music groups, reading, 


\section{ŽEMAITAITYTE்}

drama and other clubs enjoy particular popularity with the community. "Bočiai" amateur art groups appear not only during their area events, but also actively participate in various national and regional festivals. The "Bočiai" Union and its branch organisations organize regular visits to theatres and museums, scenic trips across Lithuania and abroad, memorable meetings, get-togethers and exhibitions. On average over the year "Bočiai" community holds about 1,800 different events.

One of the most important goals of the Lithuanian Retired Persons' Union "Bočiai" for all its members is to stay independent, self-sufficient and valuable members of their communities when they reach retirement age. The organisation through various activities and involvement of senior participants aims to overcome social exclusion, to respect the dignity of older people, to keep interactions among people characterised by voluntary approach, benevolence, humanity, tolerance and democratic spirit.

\section{A Song and Dance Ensemble "Poluknianie"}

An adult desiring to learn enters non-formal education and develops one's intellectual and creative strengths, gains broader social acceptance, communicates and self-expresses more dynamically. Such an adult wishes to learn led by selfeducational goals. Self-education as the highest form of individualised cognitive activity helps to develop a comprehensive, balanced personality with a position in society (Gaižutis, 1993). Cultural centres, museums, clubs, theatres are actively involved in public education. An important role is played by public libraries, which are involved in dealing with older people's social exclusion, employment, education and lifelong learning, providing opportunities for them to join a fullyfledged cultural life. According to Lithuanian Department of Statistics ${ }^{9}$ there were 867 cultural centres, 4960 adult art groups which involved about 60,000 people, including 1,404 libraries (including 1,151 rural areas) in which the total number of readers exceeds 82,3000 .

National population strategy of coping with the aging effects notes that one of the state cultural policy goals is to enable the society and each and every member of the society as well as older people to participate in cultural life, to choose their favourite pastime activities and give a possibility for self-expression. For this reason, Lithuania budgets a national fund each year for cultural and artistic projects, programmes; municipalities take care of dissemination of amateur activities, self-realisation activities in local communities. An important role is given for cultural centres, which let older people participate in various amateur art ensembles such as choirs, drama groups, folk dance and song ensembles, ethnic cultural activities, and make use of a variety of cultural services free of charge.

Cultural involvement allows older people to stay active longer, provide opportunity to participate in the life of the community and to share experience with the younger generation. This is a perfect opportunity for representatives of ethnic minorities to disseminate ethnic culture, traditions and customs; to foster one's ethnic identity, whose essence is seeing oneself as an individual combining different social roles. One such art group is Polish folk song and dance ensemble 
Poluknianie founded in 1989, uniting people of different age groups and professions: among them retired citizens, students, and teachers. Currently, there are 28 members who sing and dance in the group (Žemaitaitytè, 2012).

The ensemble's repertoire consists of Polish folk songs and dances, old grandmothers' songs, patriotic, war-time and humorous songs. The song and dance ensemble participates in various projects of reviving traditional festivals, and goes on folklore collecting expeditions. Participation of older women in the ensemble opens up the opportunity not only to show their creative abilities, but also helps to develop and preserve their old local traditions, customs, values, culture and language through songs, dances and drama. Participation of older people in the ensemble activities contributes to their personal development, spiritual renewal, teaches discipline and responsibility for their actions and choices. The members of the group are able to spend their free time meaningful and in good humour, meet various local groups from Lithuanian bigger and smaller towns, share experiences, acquire new impressions, visit sites of interest, makes Paluknis village name well known not only in Lithuania but also abroad. Since the group consists of people with different educational background, different attitudes and of different age such as grandmothers, mothers, children and grandchildren involved in common cultural activities, sincere and friendly bonds among senior and junior members allows the transfer and continuity of culture, values and traditions. On the other hand, young people inspire older people with energy, youthfulness, liveliness, and stimulate interest in new things (Žemaitaitytè, 2012).

\section{Third Age University}

Interest in adult education, and in particular in education of older people is caused by the aging of the population world-wide. At the end of 1970s the first University of the Third Age was established in Toulouse (Žemaitaityte, 2007). The term 'third age' phrase replaced the words the old or elderly (with usually negative connotation), and gave a new meaning to this period of life.

Jarvis (1996) argues that the Third Age University (TAU) is not an ordinary university (with no university campus), it is rather an expanding voluntary association that provides non-formal adult education for its members, also gives them the opportunity to get together in various interest groups and give to each other by teaching and learning. The predominant principle is that anyone can teach and anyone can learn; classes are organized in some places and there are no certificates. Formosa (2012) notes that one of the most important functions of TAU is to create a society in which aging is viewed in a positive way where older people are not discriminated because of their age, and are valued for their expertise and willingness to improve.

In Lithuania the Third Age University was established in 1995 in Vilnius. Its initiators and founders were the researchers of Experimental and Clinical Medicine in the Institute of Gerontology. Lithuanian TAU University and its departments seek to ensure that older people get opportunity of better social integration into society, promote their rich and productive life, support physical activity, work 


\section{ŽEMAITAITYTE்}

capacity, raise the level of knowledge and culture, supports health (Žemaitaitytè, 2007). Third Age University currently has branches in Kaunas, Klaipeda, Panevėžys, Šiauliai, Prienai, Marijampolè. The University has 25 faculties (Health, Religious Studies, Ethnographic and Tourism, Arts and Culture, House holding, Spiritual Development, Psychology, Languages and others), which count about 4,000 participants. Participants of the Third Age University feel that it is the most democratic educational institution. Participation in TAU activities brings about better social integration of older people into society, it promotes their productive and meaningful life, maintains their ability to work and physical activity, enhances their knowledge and culture. People can exchange experiences and maintain health. The University aims to keep the attention focused on the elderly persons, to help fulfil potentially unfulfilled possibilities, to show that he or she is not exempt from the public, but on the contrary, that they are even more appreciated.

\section{Lithuanian Association of Adult Education}

About $60 \%$ of Lithuanian NGO regulations refer to educational activities of its members in the cultural, legal and economic areas. Some, especially associations working in education, pay particular attention to the education of adults and older people (Žemaitaityte, 2007).

An indisputable leader among NGOs in non-formal adult education is the Lithuanian Association of Adult Education (LAAE) whose educational activities involve not only individual members, but also organisations. It is expanding its cooperation with other NGOs through various projects, providing support to NGO leaders, helping to consider important adult education issues of the century. During the years of restoration and consolidating of Lithuanian statehood politicians, public figures, cultural workers and researchers raised questions about public education and the ability to deal with emerging economic, social and cultural challenges. Attention was paid to the creation of the post-study education system, in the way that members should continually update their knowledge and abilities, improve and develop their qualification. In order to improve the organisation of adult education, in 1991 the Lithuanian Ministry of Culture and Education, Adult Education and Continuing Education Division assembled a group of professionals and formed an initiative group for the establishment of associations which decided to convene a constituent assembly. On February 22, 1992 the founding regulations of association and the regulatory body were approved and elected at the meeting of Initiative Lithuanian Association of Adult Education (LAAE). In order to attract more LAAE members in the Association territorial groups were formed and regional information centres were set up, which led to the rapid growth of the association of individual and collective members. As a consequence, 25 individuals and four collective members were registered in 1992; in 2000 there were already 220 individuals and 21 collective members. In 2012, Lithuanian Adult Education Association had 122 individuals and 41 collective members. In Dienys' (2002) opinion - the Association has become one of the few non-governmental organisations whose activities almost evenly covered the whole of Lithuania. 
In spring 1999 Initiative Lithuanian Association of Adult Education raised the idea of organizing the first week of adult education in Lithuania. Since 1997 with the approval of UNESCO such weeks had already taken place in many countries around the world. As reported by Lukošūnienè (2000), "firstly, I appeal to Lithuanian adult educators, inviting them to organize adult education week, it [Initiative Group] could not imagine what this initiative would become." The first Adult Learners Week was announced in 2000, which was dedicated to the general adult education issues. It was attended by 132 institutions, whereas 142 various events were held. Events were attended by 13,000 participants. Though groups of older people took active part in Learning Weeks every year in 2007 and in 2012 Learning Weeks focused on education and learning of older people. In 2007 Learning Week went under the slogan Let's learn together: children, parents, grandparents, learning through generations and common activity as the foundation for learning traditions and interaction skills in the family, community and society were emphasised. In 2012 the Leaning Week was dedicated to dissemination and implementation into the family, community, society and in the Lithuanian Adult Education Association itself, of solidarity, learning continuity and transfer of ideas. During the week active discussions were held on how the attitudes towards learning help in working environment and in retirement to accept learning as a value; on how to involve older people to the process of handing over knowledge and experience to younger generations, discussion participants were invited to share how parents can help their children and grandparents help grandchildren to learn and feel happier and the other way around, how children and grandchildren can help their parents and grandparents to overcome learning challenges. Over 112 organisations representing all Lithuanian regions took part in the week's events.

Lithuanian Adult Education Association actively contributed to the deliberations of the European Commission report titled Adult learning: Never too late. According to this paper, in 2008 a new lifelong learning strategy was approved. It should be noted that the strategy highlighted other important areas of adult education such as non-formal non-vocational adult education, which is not only important for employment or the economic well-being, but also for social cohesion, active citizenship as well as development of personal well-being of individuals. By way of generalising it is possible to say that participation of older people in NGOs activities reflect possibilities of personal growth, socialisation, and learning. NGOs functions contribute to social consolidation, solidarity and communal development growth. Participation of older people in NGOs is pre-requisite for non-formal education, development of civic society, help to fight forms of discrimination, the formation of stereotypes, and promote equal rights. Growth of civic consciousness makes citizens realize that taking part in NGOs activities and solidarity is one of the straightest ways to dealing with local problems. Participating in NGOs activities also enables older people to stay independent, self-sufficient and valuable members of their communities. 


\section{ŽEMAITAITYTÉ}

\section{NOTES}

1 The National Strategy to Overcome Ageing Consequences (2004).

(http://www3.lrs.lt/pls/inter3/dokpaieska.showdoc_1?p_id=248539\&p_query=\&p_tr2=)

2 Lithuania's Progress Strategy "Lithuania 2030", http://www.lrv.lt/bylos/veikla/lithuania2030.pdf

ICNPO, http://data.ncvo.org.uk/a/almanac13/almanac/databank/scope-2/

http://www.3sektorius.lt/trecias-sektorius/teises-aktai-dokumentai/

http://www.3sektorius.lt/trecias-sektorius/teises-aktai-dokumentai/

http://www.3sektorius.lt/docs/Ataskaita_NVO_zinomumas_santrauka_2013-01-17_16_00_05.pdf

Lietuvos pensininku sajunga "Bočiai”, http://www.socmin.tit/index.php?1825992058

Lietuvos pensininku sajunga “Bočiai”, http://www.socmin.lt/index.php?1825992058

Kultūra, spauda ir sportas (2010), www.statgov.lt/

\section{REFERENCES}

Dienys, V. (2002). O kur toliau? Savišvieta, 1, 20-26

Drucker, P. F. (2009). Drukerio mokymo pagrindai. UAB Rguop.

Europos Komisijos komunikatas. (2006). Suaugusiuju mokymasis: mokytis niekada nevélu. Accessed 16/9/14 from: http://eur-lex.europa.eu/LexUriServ/LexUriServ.do?uri=COM:2006:0614: FIN:LT:PDF

Eurostat. (n.d.). Statistics database. Accessed 16/9/14 from: http://epp.eurostat.ec.europa.eu/portal/ page/portal/statistics/search_database

Formosa, M. (2012). Education and older adults at the University of the Third Age. Educational Gerontology, 38(1), 1-13.

Fung, A. (2003). Associations and democracy: Between theories, hopes and realities. Annual Review of Sociology, 29, 515-539.

Gaižutis, A. (1993). Kultūros vertybès ir erzacai. Vilnius: Academia.

Gineitienè, D., \& Domarkas V. (2000). Visuomeninių organisaciju ịtaka viešojo administravimo institucijoms. Kaunas: Technologija,

Jarvis P. (1996). The public recognition of lifetime learning. LlinE, 1(96), 10-17.

Juozaitis, A. M., \& Vilimienè, R. (2000). Nevyriausybinès organisacijos: Nuo aiškios strategijos link efektyvios veiklos. Vilnius: Danielius,

Kultūra, spauda ir sportas. (2010). Accessed 16/9/14 from: www.statgov.lt/

Ilgius V. (1997). Valstybės parama nevyriausybinèm organizacijos - šiandien ir rytoj. Savišvieta. Vilnius: LSŠA.

Lietuvos Respublikos švietimo ministro ir Lietuvos Respublikos socialinès apsaugos ir darbo ministro įsakymas. (2008). Dèl mokymosi visą gyvenimą užtikrinimo strategijos ir jos ịgyvendinimo veiksmų plano tvirtinimo pakeitimo. Valstybès žinios, 122-4647.

Lithuania's Progress Strategy 'Lithuania 2030'. Accessed 16 September 2014 from: http://www.lrv.lt/bylos/veikla/ lithuania2030.pdf

Lukošūnienė, V. (2000). Nuo idèjos iki rezultato. Savišvieta. Vilnius: LSŠA leidykla, 4-9.

The national strategy to overcome ageing consequences. (2004). Accessed 16 September 2014 from: http://www3.lrs.lt/pls/inter3/dokpaieska.showdoc_1?p_id=248539\&p_query=\&p_tr2=

Putman, R. (2003). Democracies in flux: The evolution of social capital in contemporary society. Oxford University Press.

Sills, D. (1968). Voluntary associations. International encyclopedia of social sciences (Vol. 16). New York: Crowell-Collier,

Tūkstantmečio plètros tikslų nacionalinè analizè: bendra Lietuvos vertinimo apžvalga. (2002). Vilnius: $J T$, Accessed 16 September 2014 from: http://www.undp.lt/files//APZVALGA_lt2003.pdf) 


\section{OLDER ADULTS AS ACTIVE LEARNERS OF NON-VOLUNTARY ORGANISATIONS}

Vander Zanden, J. W. (1990). The social experience: An introduction to sociology. New York: McGraw-Hill Publishing Company,

Žemaitaitytè, I. (2007). Neformalusis suaugusiuju švietimas: plètros tendencijos dabartineje Europoje Vilnius: Mykolo Romerio universiteto leidykla..

Žemaitaityte, I. (2012). Non governmental organisations' initiatives working with the older people. In Intergenerational solidarity and older adults' education in community: The third conference of the ESREA network on education and learning of older adults (pp. 272-279). Ljubljana: Faculty of Arts at the University of Ljubljana.

\section{Irena Žemaitaityte}

Institute of Educational Science and Social Work Mykolas Romeris University (Lithuania)

Lithuania 



\section{ANN-KRISTIN BOSTRÖM}

\section{INTERGENERATIONAL LEARNING AND SOCIAL CAPITAL}

\section{INTRODUCTION}

Intergenerational learning can be seen as an entity of lifelong learning. When lifelong learning was introduced as a concept by OECD, UNESCO and EC it was connected to the theory of human capital. As such quantitative measures were used and economics outcomes were in focus. Since 2000 another concept, social capital has been used in connection to both lifelong learning and intergenerational learning. As social capital is related to culture in consequence intergenerational learning must be seen as culturally dependent with different possibilities to be adapted and to evolve depending on culture and country. This chapter will discuss a possible model for the relationship between social capital and intergenerational learning. The model will be illustrated by the use of a case study in the Swedish context involving the role of elderly people working for the benefit of children in school. The article will deal with intergenerational learning as defined as a learning taking place between different generations which involves benefits in terms of possible increased social capital for all parts involved. As social capital is sometimes described in relation to well-being and quality of life, the article sets out to clarify this connection.

\section{INTERGENERATIONAL LEARNING}

The intergenerational concept has been used differently depending on the cultural and historical context. As it was introduced in the 1970s US when intergenerational programs were invented in order to close the gaps between generations it has moved on to a recently increasingly popular status, largely related to a changing global demography. One definition is located in a UNESCO workshop:

Intergenerational programs are vehicles for the purposeful and ongoing exchange of resources and learning among older and younger generations.

(Boström et al., 2000: 3)

Now intergenerational learning is an issue in schools, in family life, in social life, in adult education and in the workplace as the segregation between generations in many countries has increased. The concept of lifelong learning has been extensively discussed ever since the end of the 1960s. In a report prepared under the leadership of Edgar Faure (1972), for UNESCO, lifelong learning was described as being largely an issue of philosophical principles with regard to the 
organization of learning. Subsequently, Coombs and Ahmed (1974) defined lifelong learning more precisely when bringing in the lifewide learning - informal, non-formal and formal entities.

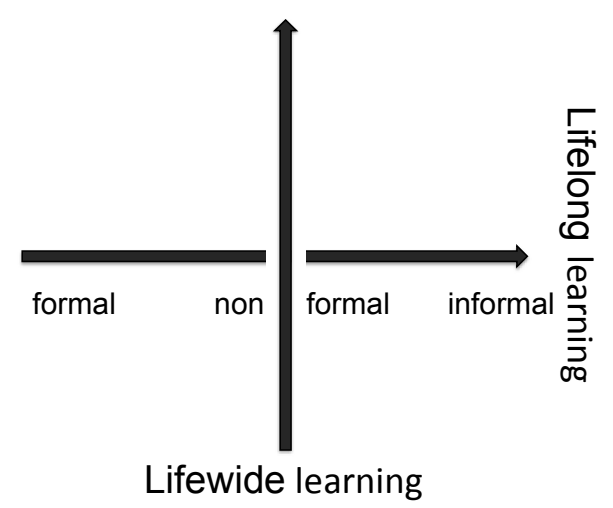

Figure 16.1. Lifelong and lifewide learning (from Cropley, 1980).

Eventually, in 1980, the term 'lifelong learning' was introduced to replace the term 'lifelong education'. A model of lifelong learning was made by Cropley (1980). His model included an aspect of learning which takes place from the cradle to the grave, as a lifelong process, and lifewide learning that included the aspects of formal, non-formal and informal learning. The model above (see Figure 16.1) included all these aspects. A historic perspective of Lifelong learning is referred to by Tuijnman and Boström (2002).

\section{SOCIAL CAPITAL}

Social capital was first mentioned/used by Coleman and Bourdieu during 1980/90s. The concept reached a peak around 2000 when many researchers were involved and used social capital in different disciplines. Coleman and Bourdieu used the concept mostly regarding relations between individuals, but later Putnam (1995, 2000) used the concept for social cohesion within national political systems and democracy. Bordieu's (1977) main concept was social capital in connection with cultural capital at the individual level. Putnam was interested in the subject from a political science perspective. Coleman introduced social capital from an educational sociology point of view (1971, 1988, 1990), and Fukyama (1996) found the concept useful from his background in economic history and sociology. UNESCO, OECD (2001), EC, and the World Bank, (Inglehart, 1999) have seen the possibilities of this concept to address the soft values that contributes to human relations, such as democracy, sustainable development, and economy. Some countries have used the concept in their policy, such as Australia (Winter, 2000). 
The definition that will be used in this chapter is Coleman's (1988: 98) where he describes that social capital is composed of several entities and involves individuals working together, trusting each other, having good communication between each other, share their values and are working towards the same goal. He argues that social capital is a compilation of various components that have the following in common: they consist of some form of social structure, they facilitate certain aspects of social structures and they facilitate certain responses on the part of various actors within the structure. These three entities consist of: (i) the level of confidence and trust, which is found in the actual social environment; (ii) those information channels, which are found there, and how information is passed between actors, and (iii), shared norms and structures that are found when people are working towards the same goal, when they are doing this on the basis of common, unselfish interests. Adler and Kwom (2002) described social capital as more than the sum of the various kinds of relationships that we entertain, and a social capital lens, therefore can reveal features of reality that otherwise remain invisible. Schuller (2000) has been writing about social capital in depth and discusses both the problems with a definition and the positive versus the negative impact of the concept. He also defines the difference between human capital and social capital where human capital relates to individuals while social capital is more about relationships between individuals and their networks. Field (2005) discussed who will participate in learning and the connection with social capital.

Intergenerational learning is a form of lifelong learning as it is a learning taking place between different generations. Learning of attitudes and values in these relationships between younger and older persons or vice versa is a form of informal learning. Informal learning is also taking place in formal settings, as in adult education. The entities of social capital are therefore included in the lifelong/ lifewide learning model (see Figure 16.2). One researcher who has studied these entities in depth is Fukyama (2000). He discussed values and trust and he described both formal values as well as informal values. Formal values are the values that are decided by law and regulations in a society, while informal values are the values that you find in every society as the attitudes, codes and acceptance of how people should behave towards each other. In Figure 16.2 the continuum of values are included in the model of lifelong learning. The two new arrows included in the model represent other entities of social capital; communication between individuals, relationships and trust. Thus, this can represent a model of intergenerational learning as these entities of social capital are working in a context where young and old people meet. This can happen in a school setting where older people work as a benefit for young students, which will be described below but can also take place in adult education when young teachers and older students meet. The model shows that intergenerational learning depends on the shared values and attitudes and is therefore cultural bound. 


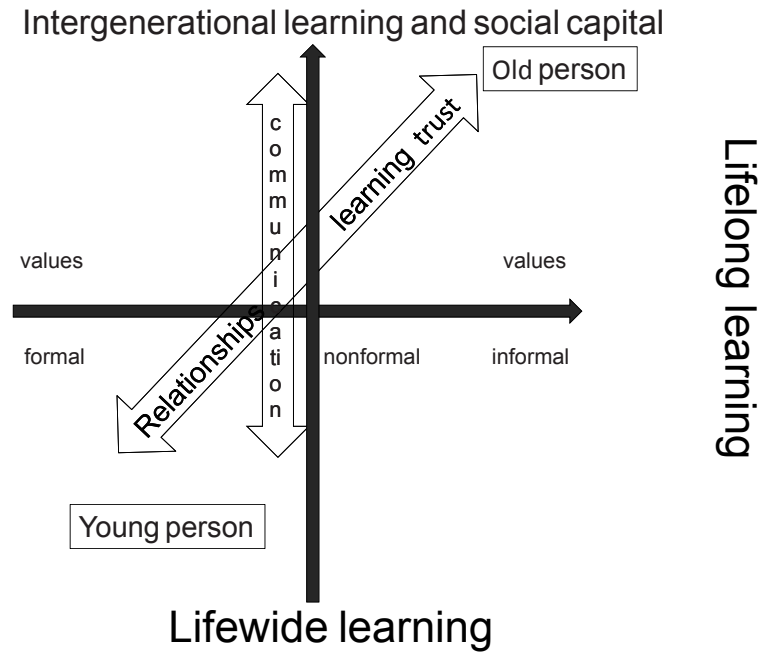

Figure 16.2. Developed from Boström (2002).

\section{INDICATORS FOR SOCIAL CAPITAL AND WELL-BEING IN PRACTICE}

In order to move into practice and see how indicators for social capital and wellbeing can be found, two cases from Sweden will be related here. First the Granddad project, an example of how intergenerational relationships in practice can increase social capital and by that also affect community development. The intergenerational project includes older men, aged 55-plus that have been working as support for young students in schools. These older men receive an introductory education at folk high schools during one semester before entering their work in the school. The course consists of both theory and practice, which give them a possibility to adapt to a new situation, required as most of them went to school during the last century, and many things have changed. The model has shown a possibility to create social capital (Boström, 2002, 2003) which contributes to both intergenerational solidarity and community development.

The theoretical background rests on a lifelong perspective and a lifewide perspective of learning. The lifewide perspective includes both formal and informal learning. Indicators measuring social capital were constructed and LISREL was used to analyse the results (Boström, 2009, 2011). In addition, a qualitative method was used to analyse the understanding and experiences of their work on the part of them as 'class granddads'. The schools that were included in the study were very different. Therefore the granddads entered very different environments when they began their work. The results indicate that their work in itself was part of the social capital that was to be found between the granddad and the pupils. The responses of the pupils indicate that both boys and girls felt they had equal opportunities in the school, that they felt secure in school and that the class granddad assisted everyone. These results support the proposition that social capital increased for the pupils. 
The responses from the participating class granddads indicate that, even though their work was very demanding, they still experienced it as very positive. They gained a social network together with the other adults at the school and very positive energy from the pupils. This indicates that there was also an increase in social capital and well-being for the granddads. The granddads answered the question what they had gained from their work in the school with the pupils and some of the answers are quoted here: "It is a wonderful feeling when the pupils come forward and ask questions about anything and everything; As a person I feel needed; I am learning how society functions today with regard to children and young people; It is stimulating to work with young people; I have learned a great deal myself".

\section{Increased Social Capital}

When the granddad is outside during the breaks, he is more on his own, which becomes apparent as an indicator in the data, being a strong component in itself. The work of the class granddad consists of many different parts. The pupils most often refer to the fact that he talks to the children and comforts them when this is needed (communication $=$ a part of social capital), that he assists everyone (security, trust $=$ a part of social capital) and that he sets limits for what is allowed (norms and structure = a part of social capital). In other words, the work of the class granddad contains all the parts that constitute social capital, according to Coleman's definition (Coleman, 1988: 98). The work of the class granddad, both together with the teacher and outside during the breaks, also influences in a positive way, the social capital between the pupils and the teacher.

\section{Malmö Longitudinal Study}

The second case from Sweden used data from a study called the Malmö longitudinal study. This study was a study of well-being and health. It started in 1938 as an investigation of intelligence and social environment. The group examined included all pupils in the third grade of Malmö's elementary and private schools - a total of 1542 pupils -834 boys and 708 girls. The majority was born in 1928. There were follow-ups 1942, 1947, 1950s, 1963-1965.

This study has both quantitative and qualitative extensive data and covers the whole life perspective of the individuals that participated. Furu (1985) made a study regarding life patterns and health and used the data from the male population in the Malmö study. There was a conceptual model constructed for the analysis of the data where the historical context, the socioeconomic resources as well as the cognitive resources and their effect on home and school processes could have an impact on the acquired level of education. This in turn was used to compare socioeconomic and work conditions, styles of living and psychosocial and mental conditions and their impact on neuro-endocrine processes and medical health indicators. The results showed socioeconomically that: 
... the healthy' middle-aged man was not better favoured than others during his childhood. The individual's cognitive ability, however, was somewhat above the total-group average. In adulthood the healthy man is characterised by stable socioeconomic conditions, relatively speaking. His level of education is average and income is slightly above the total-group average. The group has a small proportion of divorces (5\%), low criminality, and few have received social assistance. By and large, working conditions do not differ from the total average. Most can relax after a normal working day and do not find their work uncongenial. Few have experienced continual stress during the past five years. (Furu, 1985: 147-148)

The Malmö longitudinal study was also used by Bang (1992) when she asked if quality of life could be measured. By doing a thorough literature review she as a starting point chose 3,432 documents with the indicators: happiness, life satisfaction and quality in life. She found 143 articles and described 34 articles and how they try to measure quality in life. Quality in life was explicitly used by another study by Bang (1995). This study dealt with retirement and quality of life where network and health were found to be the most important dimensions.

\section{WELL-BEING}

The concept of well-being has been used for a long time as seen from the studies from the Malmö longitudinal study. It has mostly been used in the context of health and from a psychological perspective. In this arena it is normally referred to as subjective well-being. Recently well-being has been used in policy when trying to measure and compare societies. In order to do this there was a need for indicators which have been used in several policy sectors as health care, public health, social services, parks and recreation, work life, transportation families and the environment. Diener (2005) has worked with indicators for well-being. He argues that they are not exact but they are useful and they fulfill a need. He means that individuals personal subjective well-being can have an impact of society as a whole. The definition of subjective well-being according to Diener (2005) is:

Subjective well-being refers to all of the various types of evaluations, both positive and negative, that people make of their lives. It includes reflective cognitive evaluations, such as life satisfaction and work satisfaction, interest and engagement and affective reactions to life events, such as joy and sadness. (Diener, 2005: 2)

There is also a definition of quality in life which explains the difference between the two concepts.

Quality in life usually refers to the degree to which a person's life is desirable versus undesirable, often with an emphasis on external components, such as environmental factors and income. In contrast to subjective well-being which is based on subjective experience, quality of life is often expressed as more 
"objective" and describes the circumstances of a person's life rather than his or her reaction to those circumstances, (Diener, 2005: 4)

Dodge and colleagues (2012) went in their article with the challenge of defining wellbeing in depth with the literature, mostly from the psychological perspective. Aiming to look for what kind of definitions they could find. However most of the definitions were mainly descriptive so they argued for a new definition.

There are several international reports that are using indicators for wellbeing. One of these is the European Quality of Life Survey (EQLS) (European Commission, 2013). The third wave of this study was conducted during 20112012. The study covered 27 European Union Member states at the time of the study and seven candidate or pre-accession countries. The survey was conducted with face to face interviews and had representative estimates at the national level. It covered the population $18+$. There was a need for a definition of subjective wellbeing and a framework when trying to measure the outcome of wellbeing in Europe. Subjective wellbeing in this case is referred to as "experienced wellbeing to highlight that it reflects people's experiences of their lives" (ibid.: 12). There was also need for a framework and a conceptual model, see below a model adapted from Thomson and Marks (2005) displayed in Figure 16.3.

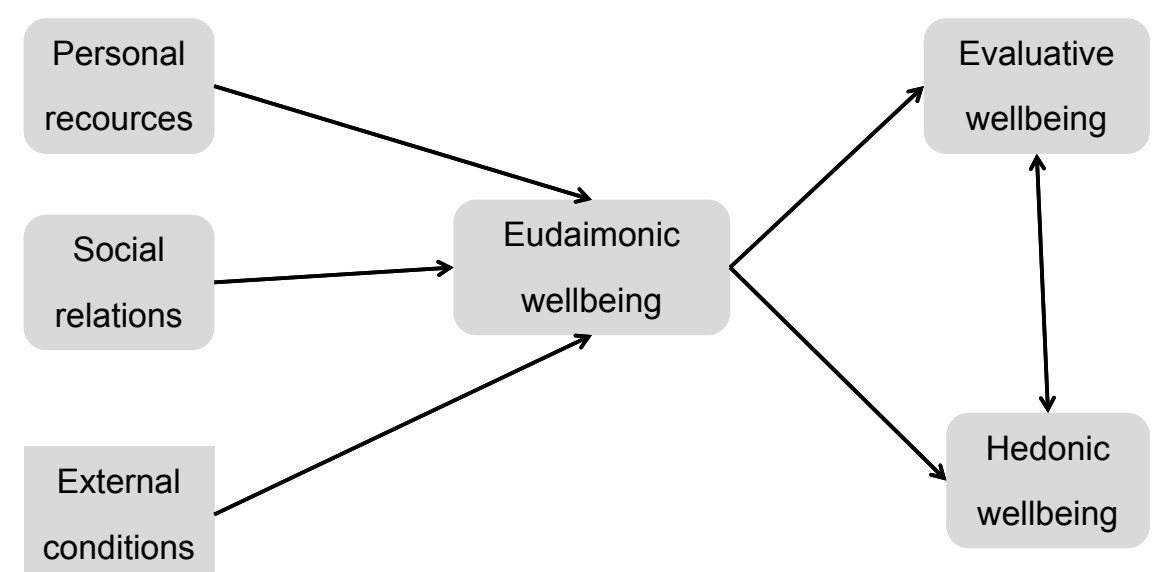

Figure 16.3. Adapted from Thomson and Marks (2008).

The model includes three main aspects. The hedonic wellbeing refers to people's day-to-day feelings and moods. The evaluative wellbeing refers to how satisfied people are with their lives as a whole nowadays and the eudemonic wellbeing refers to concepts that are believed to be important to wellbeing. Some of these are people's sense of autonomy, relationships meaning and self-esteem. These concepts are sometimes seen as preconditions for wellbeing. Examples of 
questions for these aspects are for the hedonic aspect; I have felt cheerful and in good spirits, I have felt downhearted and depressed. For the evaluative aspect the questions among other were; how satisfied are you with following items? Your education, standard of living, your present job, your family life, your health, your social life? The Eudaimonic aspect had the following statements that they had to consider: "I am optimistic about the future; I feel I am free to decide how to live my life; I feel left out of society".

The results from the measurement of quality in life show that face-to-face contact with friends had a strong impact on well-being while indirect contact (by phone or e-mail) had almost no impact. The strongest predictor of wellbeing were material deprivation, health, work-life balance, lack of time, and satisfaction with public services. The predictors varied according to the measure being used. For example, the strongest predictor of loneliness was being widowed, while the strongest predictor of stress was work-life balance. The data also highlights the importance of protecting social networks and relationships. For example this highlights the importance of considering the unintended social consequences associated with increasing geographical labour mobility, or the falling social cohesion and trust associated with increased inequality.

Therefore the author of this chapter suggests an additional part in the conceptual model of measuring wellbeing (see Figure 16.4).

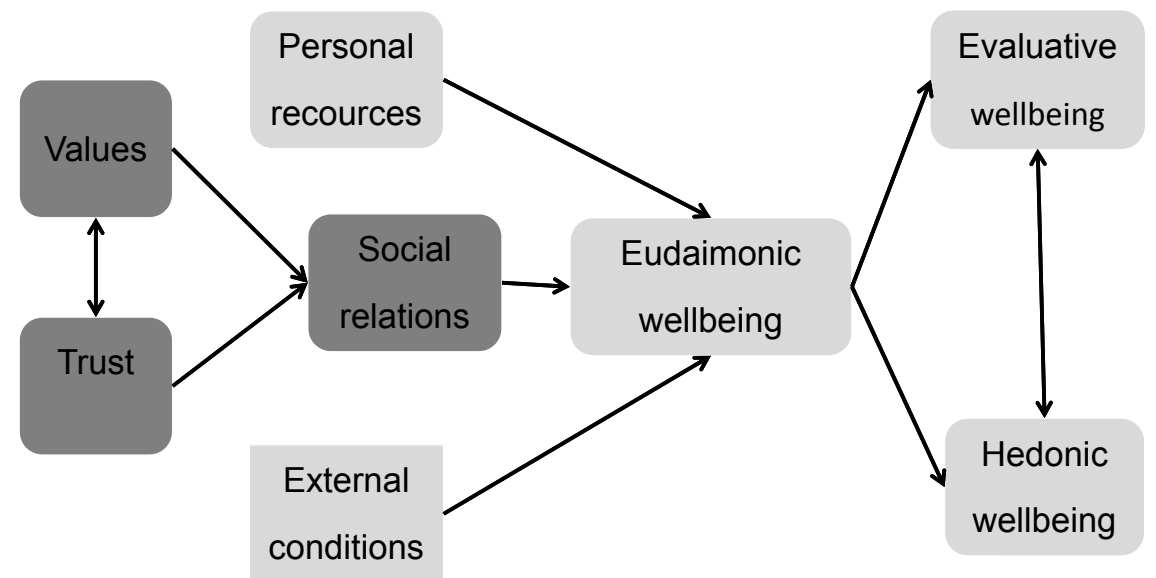

Figure 16.4. Social capital within the framwork of wellbeing.

That 'social relations' is part of the model is important in the concept of wellbeing. It is also found in the Malmö longitudinal study. Social capital as a concept involves relationships but also values, communication and trust are important entities in this concept as a whole. If the three entities of social capital are included in the model, social capital can be part of the framework. This places social capital in the context of well-being. As social capital is used (Coleman, 1988: 98) within 
family or defined groups of agents it is possible to measure social capital in networks or relationships but also to compare in a broader perspective. This model illustrates the fact that social capital is connected to the actual context and culture. In the model these parts are represented by the perspectives of 'external conditions' and 'personal resources' held by the individual.

\section{DISCUSSION}

There is a tendency for creating new concepts to use in policy. Lifelong learning and human capital were the two first going together, later lifelong learning was also connected to social capital. Recently intergenerational learning and wellbeing have been introduced. Researchers struggle to define the concepts and use them for research. At the same time the public or media use the concepts, but for their own purposes. In this chapter the concept of intergenerational learning has been introduced and illustrated as how it is connected to social capital. The concepts of well-being and quality in life were described in arguing the need for a clear distinction between these concepts and social capital. The results from the Malmö longitudinal study show that network and relationships are key for well-being.

The granddad program indicated that intergenerational learning connect individuals from different generations and have a possibility for creating social capital. Learning and social capital have been developed and defined by Field and Schuller (1997):

social capital treats learning not as a matter of individual acquisition of skills and knowledge, but as a function of identifiable social relationships. It also draws attention to the role of norms and values in the motivation to learn as well as in the motivation to learn as the acquisition of skills and the deployment of know how. (Schuller, 1997: 17)

Another perspective is taken by Schuller et al. (2004) when the benefits of learning and the impact of education on health, family life and social capital is researched and the important effects of learning to self-esteem are demonstrated.

Within the EQLS survey the subjective wellbeing is measured from different perspectives. Social relations are reported regarding relationships, networks, faceto-face communication and trust. Social capital is connected to the context that sets the base for what can be achieved. Personal resources and external conditions are the preconditions for the possibilities of increased social capital. This becomes even more evident in intergenerational meetings. As social capital is related to culture it is also evident that intergenerational learning will be adapted differently and have different possibilities to grow in countries dependent of policies regarding volunteering, social benefits and historical background.

Research within this area has to be increased and supported and intergenerational relations have to be taken into consideration as a part of policy actions to make generations unite towards their common future. Misunderstandings and lack of information can put a stop for intergenerational learning. The concept of social capital and the concept of well-being are not the same and cannot be used 


\section{BOSTRÖM}

interchangeably. This is argued as important as the concepts are differently defined. As an example, health is an important part of well-being but even if you are in bad health you can enjoy relationships that give you increased social capital and learning that can take place "from the cradle to the grave".

In conclusion, intergenerational learning is connected to social capital and social capital is a part of well-being.

\section{REFERENCES}

Adler, P., \& Kwom, S.-W. (2002). Social capital: Prospects for a new concept, Academy of Management Review, 27(1) 17-40.

Bang, H. (1995). Retirement and the quality in life. Stockholm: Institute of international Education, Stockholm University.

Bang, H. (1992). Can quality be measured? A literature review. Stockholm: Institute of international Education, Stockholm University.

Boström, A-K. (2002). Informal learning in a formal context: Problematizing the concept of social capital in a contemporary Swedish context. International Journal of Lifelong Education. Volume, 21(6), 510-524.

Boström, A-K. (2003). Lifelong learning, intergenerational learning, and social capital: From theory to practice. Stockholm: Institute of International Education, Stockholm University.

Boström, A-K. (2009). Social capital in intergenerational meetings in compulsory schools in Sweden. Journal of Intergenerational relationships, 7(4), 425-441.

Boström, A-K. (2011). Lifelong learning in intergenerational settings: The development of the Swedish Granddad program from project to National association. Journal of Intergenerational Relationships, 9(3), 293-306.

Boström, A-K., Hutton-Yeo, A., Ohsako, T., \& Sawano, Y. (2000). A general assessment of IP initiatives in the countries involved. In A. Hutton-Yeo \& T. Ohsako (Eds.), Intergenerational programmes. Public policy and research implications: An international perspective. Hamburg: UNESCO Institute of Education and Stoke-on-Trent: The Beth Foundation.

Bourdieu, P. (1977). Outline of a theory of practice. Cambridge: University Press.

Coleman, J. S. (1971). Resources for social change. New York: John Wiley \& Sons

Coleman, J. S. (1988). Social capital in the creation of human capital. American Journal of Sociology, 94, S95-S120.

Coleman, J. S. (1990). Foundations of social theory. Boston: Harvard University Press.

Coombs, P. A., \& Ahmed, M. (1974). Attacking rural poverty: How nonformal education can help. Baltimore: John Hopkins University Press.

Cropley, A. J. (1980). Towards a system of lifelong education. Oxford: Pergamon Press.

Diener, E. (2005). Guidelines for national indicators of subjective well-being and ill-being. Accessed 17 December 2013 from: http://internal.psychology.illinois.edu/ ediener/Documents/Guidelines_for_ National_Indicators.pdf

European Commission. (2013). Quality of life in Europe: Subjective well-being. Luxembourg: Publications Office of the European Union

Dave, R. H. (Ed.). (1976). Foundations of lifelong education. Oxford: Pergamon Press.

Field, J. (2005). Social capital and lifelong learning. Bristol: The Policy Press.

Field, J., \& Schuller, T. (1997). Social capital, human capital and the learning society. International Journal of Lifelong Learning, 17(4), 226-235.

Freedman, M. (2007). Encore, finding work that matters in the second half of life. New York: Public Affairs.

Fukuyama, F. (2000). The great disruption, human nature and the reconstitution of social order. New York: Touchstone. 


\section{INTERGENERATIONAL LEARNING AND SOCIAL CAPITAL}

Furu, M. (1985). Life patterns in health. A longitudinal study of men from childhood to middle age. Stockholm: Gleerups.

Inglehart, R. (1999). Trust, well-being and democracy. In M. Warren (Ed.), Democracy and trust (pp. 88-120). Cambridge: Cambridge University Press.

OECD. (2001). The well-being of nations: The role of human and social capital. Paris: Author.

Putnam, R. D. (1995). Bowling alone: America's declining social capital. Journal of Democracy. Vol.6, 65-78.

Putnam, R. D. (2000). Bowling alone: The collapse and revivial of American community. London: Simon \& Schuster.

Schuller, T., Preston. J., Hammond.C., Brasset-Grundy. A., \& Brynner, J. (2004). The impact of education on health, family life and social capital. London: RoutledgeFalmer.

Thompson, S., \& Marks, N. (2008). Measuring well-being in policy: Issues and applications. London: nef.

Tuijnman, A., \& Boström, A-K. (2002). Changing notions of lifelong education and lifelong learning. International Review of Education, 48(1-2), 93-110.

UNESCO. (2001). Revisiting lifelong learning for the 21st century. Hamburg: UNESCO.

Winter, I. (2000). Social capital and public policy in Australia. Melbourne: Australian Institute of Family Studies.

\section{Ann-Kristin Boström}

National Centre for Lifelong Learning (ENCELL)

University of Jönköping

Sweden 



\title{
MARVIN FORMOSA, SABINA JELENC KRAŠOVEC \& BERNHARD SCHMIDT-HERTHA
}

\section{CONCLUSION}

\author{
Policy Futures in Older Adult Education and Intergenerational Learning
}

\section{CONTEXTS}

Learning in later life and intergenerational learning happens in a broad range of diverse contexts, providing not only benefits for the learners and the communities they live in, but also being a necessity for the future of ageing societies and its citizens (Findsen \& Formosa, 2011).

The contributions to this book, which picked up different aspects of older adults learning and intergenerational exchange partly from a broader European perspective and partly through the lenses of different European nations, cannot simply be summarized in a couple of central messages. Nevertheless, there are some conclusions that can be drawn from the different perspectives, which in many cases are presented for one country but stand as an example for other countries or regions facing the same challenges. In this sense, the different chapters show that learning in later life and intergenerational learning is not limited to organized educational programs but happens in different contexts and often unintentional but can be fostered by providing adequate framework conditions.

Across the different chapters, six contexts can be identified which seem to be central for the education of older adults and intergenerational learning in different ways: the family, the workplace, voluntary work, the community, citizenship, and last but not least, educational programmes.

\section{LEARNING IN THE FAMILY}

The family is an important place not only for intergenerational exchange but also for getting in touch with new fields of knowledge and being confronted with new challenges. As social networks become smaller and more exclusive when people get older, relationships within the family become more and more central for many older adults (Atthias-Donfut, 1997). Family is the place where different generations come together day by day and share their experiences, sorrows, and interests. Even if this optimistic perspective on families might still be the reality for many people, there are different developments challenging the idea of family as a place where people of all ages come together. Globalization and the borderless European labor markets attract or force many young people to leave their homes, leaving parents and grandparents behind. In this sense scholars talk about 
multilocal families, which rarely meet each other in person but keep in touch via different ways of telecommunication.

Even if $80 \%$ of older people in need of care live within their families in Germany, there seems to be a trend to send older relatives in nursing homes in many countries - as Antonio Fragoso reported in detail for Portugal. Families as multigenerational communities are in danger of being broken up as a consequence of globalized labor markets and the primacy of work in individual time plans. Alfredo Alfagame therefore argues for a temporary exit from work and more flexible models of retirement, for example when parents or partners are in need of care. This is not only of interest from the perspective of overloaded social systems but this is an important topic in many ways. Here, it cannot be discussed what it means for the relationship and the individual wellbeing when families are able to live together even when a member becomes in need of care. But for the main focus of this book it is important to reflect on the learning opportunities within families which are of course not independent from their living conditions.

Families are meaningful places of learning in every stage of the ageing process. For example, when cultural traditions and knowledge about the cultural roots of a family are transferred from generation to generation (Kump \& Jelenc Krašovec, 2010), and in the same way new facets of the culture a family lives in can be brought in by the younger family members (Schmidt-Hertha \& Thalhammer, 2012). Learning within a family seems to depend on family structure and the possibility of family members to interact with each other on one hand and on relationships between family members, the allocation of roles within the family, and the attributed expertise of family members on the other (Thalhammer \& Schmidt-Hertha, forthcoming).

Families initiate learning of its members by providing new tasks and challenges to them, even in later life. New roles - such as becoming a grandmother or grandfather - can lead to increased opportunities for informal and non-formal learning (Strom \& Strom, 2000) or the social media worlds of younger peers can also give rise to new models of older adult learning - as Veronika Thalhammer mentioned in her chapter. It seems that family is still the most important learning context for many older adults, even if families become smaller, and are more often widely spread across the country, continent or even globally. It would be of interest to get deeper into the learning processes inside families and also to launch international comparisons, which are so far non-existent.

Policy is therefore challenged to support informal learning within families by strengthening families and their rights. It is important to recognise engagement processes in families, and to protect families as an important basis of our learning societies, in particular in times of globalised markets and a dominance of neoliberal economy in most policy fields. 


\section{WORKPLACE LEARNING}

A little more is known about learning at the workplace and the relevance of employment status and working conditions for participation in lifelong learning (Schmidt, 2007; Tikkanen et al., 2002). The probability of participating in continuing vocational training and adult education is the highest for white-collar workers who are fully employed, work in larger companies, and have a high level of qualification (Schmidt, 2007; Desjardins \& Rubenson, 2013). But also informal learning at the workplace is strongly related to working conditions, level of qualifications, size of the company, and the branches (Tikkanen et al., 2002). This is also true for older workers who are underrepresented in work-related non-formal and informal learning. As Tarja Tikkanen demonstrates in her chapter, this does not mean that older workers are less qualified. International comparisons show, that in some countries older workers are deeply involved in vocational education and workplace learning, what might be a result of more positive images of ageing and a higher level of appreciation for older workers knowledge, experiences, and qualifications. Even in times of demographic change when the meaning of older workforce for economies and companies is obvious, many employers still seem to have prejudices and negative perceptions to their older workers, and don't recognize the innovative potentials of this group (Poulston \& Jenkins 2013).

However, older workers are often seen as a meaningful resource in context of knowledge management strategies, when it comes to the question how to transfer the experiential knowledge of older workers to the younger ones in order to keep the knowledge inside the enterprise when people retire (e.g. Thomson, 2004). Here once again intergenerational learning comes into the picture, but often in a very unidirectional sense. Intergenerational learning in this context is often understood as a one-way transfer of knowledge from the experienced older workers to the younger ones. Bernhard Schmidt-Hertha criticizes that the label intergenerational learning is used in a very broad manner for completely different kinds of learning. The only thing they have in common is the participation of people of different age. He argues for a more egalitarian and reciprocal character as a central quality of intergenerational learning and claims that there is a lack of clarification of the meaning of "generations" when the term intergenerational learning is applied. In particular, work-related learning intergenerational learning can provide concepts which neither ignore the competencies and knowledge of older workers nor their potential to learn from their younger colleagues. In this sense, both groups younger and older workers - have to be perceived as simultaneously learners and teachers at the same time when it comes to intergenerational learning.

It is opportune here to reflect on the ideas of Alfredo Alfagame which did not cease at the oft-cited possibility to reduce working hours or to stop working temporarily for family reasons or education. The model would also include the possibility to work far beyond the usual (or in some countries legal) retirement age. For employers, the consequence would be a much more age heterogeneous workforce, which can be seen as a challenge but also as a chance, especially in the sense of intergenerational learning. So far, only very few data was collected and 
studies conducted on people working beyond the age of 65 . However, some initial results from a qualitative investigation in Germany on employees beyond the legal retirement age point to the exchange with younger colleagues and the possibility to bring in their experiences and skills as two important motivations to continue working (Setzer, forthcoming).

As work is an integral part of many peoples' lives - even older members policy has to ensure that there is a possibility to participate in work for those older adults who want to, to make competencies of older workers visible and to develop systems to validate their knowledge and competencies.

\section{LEARNING IN AND BY VOLUNTARY ENGAGEMENT}

Paid work is one way to fulfill the need for experiencing ones' own competence, autonomy and relatedness (Deci \& Ryan, 1987), but these central needs can also be satisfied in unpaid voluntary work, which seems to be attractive for many older adults and gives them the possibility to contribute to the social environment, the community and the society they live in. Within later life, two forms of voluntary activities and civic engagement can be distinguished. One is voluntary work for others which is appreciated more and more in civic societies which are relying on this kind of engagement to keep their social services and in particular the social cohesion alive. This is underlined by Malgorzata Malec in her chapter, when she points out the benefits on both sides - the societies who can profit from the older adults experience, knowledge and energy, and the older adults themselves who improve their quality of live and wellbeing. At the same time voluntary work offers and demands learning. In many countries - such as in Poland - it seems that first of all the well-educated and privileged older adults are engaged even if there might be many others more interested in such kind of activities. Keeping in mind the learning possibilities offered by voluntary work, the contribution of older adults to a civic society, and the positive effects of civic engagement on active ageing and wellbeing, it seems to be an important challenge to give interested older adults the possibility to do meaningful work in their communities and social surrounding. For the less privileged, it might be necessary to encourage them actively for civic engagement.

The second form of civic engagement in later life is an active membership in special older people's organizations and clubs. Like Irena Žemaitaityte shows in her contribution, an enormous growth of NGOs for older adults in Lithuania can be recognized which might be similar in many other countries. More and more older people come together and engage themselves in organizations which either give them political power and influence to stand up for their interests or build a forum for people with the same interests and the same generational experiences (Mannheim, 1928). Here older adults learn not only by new tasks and challenges they are confronted with but they learn with each other and from each other as well as they engage to preserve the knowledge and experiences of their generation for the following ones. 
This also means that both forms of voluntary activities mentioned here provide different chances for intergenerational learning. As regards the former - which is often called 'engagement for others' - intergenerational exchange happens within the organization or group and is often part of the voluntary work itself, as the ones who are in need of help might belong to another generation. Intergenerational learning here means coming together with representatives of other generations and learning from them and in particular about them, which - as Bernhard SchmidtHertha argues in his chapter - is a very ambitious form of intergenerational learning. In the second form of engagement - generally termed 'engagement for ones' own belongings' - the intra-generational communication and exchange is dominant. Yet, this intragenerational learning usually aims at communicating experiences, knowledge and perspectives of the own generation to others and especially let younger generations learn from that at least to make them better understand the older generation and their own roots.

As voluntary work is the backbone of civil societies, policy must not only have an interest in promoting civic engagement, but also to build up educational programs and learning support for engaged older adults to assist them in preparing themselves for their challenging tasks.

\section{LEARNING IN THE COMMUNITY}

In both forms of voluntary work there are more informal (e.g. neighbourhood assistance) and more formal (e.g. honorary offices) ways of engagement. Most forms of engagement are somehow related to the community, which is - like different chapters in this book point out - a very meaningful context for learning in later life in general and for intergenerational learning in particular. Antonio Fragoso perceives community as a micro cosmos where social inclusion and cohabitation is realized within the frameworks of national and supranational politics, cultural traditions and economic conditions but always with a more or less high level of possibilities for shaping local ways of living together. This means the community level is very important when it comes to the question if social cohesion and welfare is understood as a public or a private task. Beyond that, Barry Hake makes clear that communities are not only driven by local politicians and policies but by the engagement and activities of their members. As can be learned from the example of urban gardening in public places, communities are co-designed by local initiatives, citizens' movements, and the way people make use of public spaces. The chapter of Barry Hake also sheds light on the irreducible interaction of engagement and activities in the community on the one side and learning processes on the other side - not least intergenerational learning. Wherever people come together to design the social and physical environment they live in, learning most likely is an instrument for and a consequence from these activities.

For older adults - more so than for other social groups - the community level is of importance for their social life, when mobility decreases in later life. When the radius of action becomes more limited also in a geographic sense, the local surrounding gets more and more important and becomes the most important 
resource of areas of action, learning opportunities, and intergenerational encounters. It is the chapter of Sabina Jelenc Krašovec and Sonja Kump that shows us how national policies can have an impact on local structures. At the same time they also raise the question about the quality of such top-down initiated activities. Contrasting the initiatives they describe in Slovenia with the bottom-up processes presented by Antonio Fragoso and Barry Hake it is clear that the latter ones include learning processes by nature and provide very natural forms of intergenerational learning, while the top-down initiatives have to convince and activate their target groups first. And even if they succeed to activate citizens they are still at risk to become formalized institutions which only act on a very surface level.

It is therefore apparent that communities as the most important level of solidarity have to be strengthened by policy, especially as they often seem to be the weakest part when it comes to cut down public households. Further on, communities are driven by their citizens and especially older adults are able and in many cases willing to contribute significantly to the development of their communities. Policies have to empower them to do so and offer free spaces for their citizens to design their way of living and learning together.

\section{CITIZENSHIP AS A FIELD OF LEARNING}

Citizenship even beyond local institutions and initiatives provides meaningful impulses and aims for learning in later life. George Zarifis makes clear, that older adults - in particular in times of financial crisis - are at risk of social exclusion and marginalization in many European societies. He paints a rather skeptical picture of older adults' lives, especially looking at the marginalized seniors who are socially excluded in many ways. It seems that especially senior citizens in the southern countries are at risk of being excluded from active social participation and that these challenges cannot be solved only on a national level but require the solidarity of the whole of Europe.

For educational systems this means a threefold mandate. The first task is to contribute to solidarity in Europe at all stages of education, from school to vocational and higher education to adult education. The second task is to educate older citizens to raise their voice in a dynamic and more unique European Union, a voice which might be less recognizable to them in comparison to younger generations who grew up in a united Europe. In times of an accelerated increase in the influence of European policy in the member countries, intergenerational learning and confronting the memories of older adults related to a Europe in war with the implicit way younger people behave in a Europe without borders, might be an important way of political education. The third task is directly related to that kind of civic citizenship for older adults where they also need competence to safeguard their own interests. From the viewpoint of underprivileged seniors educational offers have to contribute to strengthen their position in society.

Esmeralidina Veloso and Paula Guimãres follow findings from critical gerontology when they claim a liberal education in the sense of Freire, which leads to empowerment and emancipation of citizens at the same time. They recognize 
inequalities within the group of senior citizens as well as the risk for older adults of becoming second class citizens. Therefore it seems even more important to combine both educational aims - the individual empowerment and the emancipation of social groups - as important tasks for education of older adults. Wildemeersch and Salling Oleson (2012) indicate that both educational goals, emancipation and empowerment, have been emphasized differently in the history of European educational policy and they demonstrate a shift from the emancipation of social groups to individual empowerment. With that in mind it is even more important to underline the meaning of both educational processes for an active and satisfying citizenship at all ages. Furthermore, this kind of civic education can also contribute to the increase of social capital on the individual as well as on the societal level - as Ann-Kristin Boström makes clear in her chapter - if they make use of the potential of intergenerational learning. Taking into account the differences in the way intergenerational learning is realized and its various effects depending on the cultural background, she assumes a general relation between social capital and intergenerational learning which is not only plausible but confirmed by empirical evidence.

Liberal education is often under pressure in face of dominant economic interests in adult education. Policies are required that ensure sustainable structures of liberal education in every region and with a focus on empowering older adults but also on emancipating them.

\section{LEARNING IN ADULT EDUCATION INSTITUTIONS}

All the aims and challenges of learning in later life and intergenerational learning cannot only be addressed informally or as a byproduct of other activities. Educational institutions have to take responsibility for imparting the necessary knowledge and competences and to empower older adults to participate in the fields mentioned above. To reach their target group, educational programmes have to meet the interests and address the learning needs of older adults as well as provide suitable environments for intergenerational exchange. In different chapters many of prerequisites for successful learning arrangements have been worked out, while only some central points can be picked up here.

One important message is to shed light on the relation between educational offers and the regional, national, or supranational policies they are framed by. Marvin Formosa claims a holistic approach in older adults' education, respecting the heterogeneity within the target group "older adults" as well as inter-individual and intra-individual differences in learning aims and learning needs. This has to be taken into account by adult education providers and by policy makers in the same way, and both have to be related to one another. The points levelled by Marvin Formosa is also underlined by Veronika Thalhammer, when she refers to a relation between the success of ICT-supported learning environments for older adults and their embeddedness in political strategies of superordinate policy units. In other words, local learning projects and supra-regional policies have to be related to each other and have to reflect the heterogeneity of learning interests, biographical 
backgrounds, and living conditions in later life to provide learning arrangements that meet the needs of older learners.

So far empirical studies focusing on the interaction of local initiatives and policies on the regional, national or European level are rare. Sabina Jelenc Krašovec and Sonja Kumps contribution is an example for this kind of investigations, focusing on the impact of national policies, while other studies pick up policy effects on the regional (Emminghaus \& Tippelt, 2009) or European level (Zarifis \& Gravani, 2014). Almost nothing is known about the interaction of different policy levels and the common effect on educational practice. Taking into account the heterogeneity of older adults, Dominque Kern reminds adult education providers to define the target group precisely, to reflect on their interests but also to take into account that learning arrangements are not only obliged to the requests of participants but also to assist them in developing new learning interests and to address conscious learning needs. But even if this mission of educational programs is fulfilled adequately, there still remains the fact that many older adults (in particular older adults with low levels of qualification) who might be interested in learning are not reached by educational offers. Addressing this challenge could be one of the central challenges for policy, educational institutions and research in the future. The Australian model of men sheds, Barry Golding introduced in his chapter, is one example for a strategy to provide learning opportunities for those who are less likely to access adult education. Looking at the success story of that initiative, it can be stated that more strategies of this kind are needed to make lifelong learning a reality for all older adults and to encourage them to shape the future of their societies.

After an ongoing phase of expansion, during which programs for the education of older adults as well as intergenerational learning programs have been fostered and installed more and more all over Europe, it seems important to draw more attention to the quality of these educational offers. This is claimed by a couple of authors within the chapters of this book, for example by Bernhard Schmidt-Hertha who proposes some core principles to develop intergenerational learning programs but also makes clear, that quality in enhancement in this filed cannot be realized without further professionalization. It seems obvious but nevertheless to upgrade the qualifications of professionals is a central desideratum in adult education in general and in older adults' education in particular. In intergenerational learning scenarios - as described for example by Ann-Kristin Boström by introducing the granddad programme - adult educators often seem to play a less important role, when they just moderate the process or prepare the environment for intergenerational encounters. It would be a wrong conclusion to expect a reduced impact of professionals in that kind of programs. Adult educators here are challenged to cope with conflicts or avoid them, to activate participants and to ensure a friendly atmosphere of trust and privacy.

Educational institutions are dependent on policies that enable them to provide educational programs for older adults even if they are not able to pay high fees. For adult education institutions it might be more attractive to offer continuing vocational education and other programs that are more likely to attract customers 
who are able to pay high participation fees, if policies do not intervene with funding programs.

After the consequences of demographic change and the necessity to enhance the participation of older adults in lifelong learning are discussed all over Europe and after the European Union started a big campaign for intergenerational learning within the European Year on Active Ageing and Solidarity of Generations 2012, it seems time to put the quality of all the new initiatives and policies on the table. From a research perspective there is knowledge related to the question how to design high quality learning environments for older adults or intergenerational groups, even if a broad range of research desiderata also became visible. There are still a lot of unanswered questions when looking closer at the relevant educational programs. This book tried to contribute to both, to sum up existing research results and provide some new impulses as well as to point on the gaps of knowledge and the open research questions.

\section{REFERENCES}

Atthias-Donfut, C. (1997). Family relationships in France: The experience of older people. Ageing International, 24(1), 32-50.

Deci, E. L., \& Ryan, R. M. (1987). The support of autonomy and the control of behaviour. Journal of Personality and Social Psychology, 53(6), 1024-1037.

Desjardins, R., \& Rubenson, K. (2013). Participation patterns in adult education: The role of institutions and public policy frameworks in resolving coordination problems. European Journal of Education, 48(2), 262-280.

Findsen, B., \& Formosa, M. (2011). Lifelong learning in later life: A handbook on older adult learning. Rotterdam: Sense Publishers.

Kump, S., \& Jelenc Krašovec, S. (2010). Intergenerational community learning, education and cooperation. Teorija in Praksa, 47(6), 1171-1194.

Mannheim, K. (1928). Das Problem der Generationen. Kölner Vierteljahreshefte für Soziologie, 7(2), 157-185.

Poulston, J., \& Jenkins, A. (2013). The persistent paradigm: Older worker stereotypes in the New Zealand hotel industry. Journal of Human Resources in Hospitality and Tourism, 12(1), 1-25.

Schmidt, B. (2007). Older employee behaviour and interest in continuing education. Journal of Adult and Continuing Education, 13(2), 156-174.

Schmidt-Hertha, B., \& Thalhammer, V. (2012). Intergenerative Aneignung von Medienkompetenz in informellen Kontexten. In A. Hartung, B. Schorb, \& C. Kuttner (Eds.), Generationen und Medienpädagogik. Annährungen aus Theorie, Forschung und Praxis (pp. 129-148). München: Kopaed-Verlag.

Setzer, B. (forthcoming). Erwerbstätige ältere Menschen. In J. Friebe, B. Schmidt-Hertha, \& R. Tippelt (Eds.), Kompetenzen im höheren Lebensalter: Ergebnisse und perspektiven der studie "competencies in later life". Bielefeld: Bertelsmann.

Strom R., \& Strom S. (2000). Intergenerational learning and family harmony. Educational Gerontology, 26(30), 261-283.

Thalhammer, V., \& Schmidt-Hertha, B. (in preparation). Intergenerationelle innerfamiliäre Unterstützungsprozesse bei der Mediennutzung von älteren. Zeitschrift für Erziehungswissenschaft.

Thomson, J. (2004). Older, wiser and retiring. Business Review Weekly, 26(4), 66-67.

Tikkanen, T., Lahn, L. C., Withnall, A., Ward, P., \& Lyng, K. (2002). Working life changes and training of older workers. Brussels: European Commission. 
FORMOSA, JELENC KRAŠOVEC \& SCHMIDT-HERTHA

Wildemeersch, D., \& Salling Olesen, H. (2012). Editorial: The effects of policies for the education and learning of adults - From 'adult education' to 'lifelong learning', from 'emancipation' to 'empowerment'. European Journal for Research on the Education and Learning of Adults, 3(2), 97101.

Zarifis, G., \& Gravani, M. N. (Eds.). (2014). Challenging the 'European Area of Lifelong Learning': A critical response. Dordrecht: Springer.

\section{Marvin Formosa}

Gerontology Unit, Faculty for Social Wellbeing

University of Malta

Malta

Sabina Jelenc Krašovec

Faculty of Arts

University of Ljubljana

Slovenia

Bernhard Schmidt-Hertha

Institute of Education

University of Tuebingen

Germany 


\section{ABOUT THE CONTRIBUTORS}

\section{EDITORS}

Marvin Formosa, Ph.D., is Senior Lecturer within the Gerontology Unit, University of Malta. His key interests are critical gerontology and educational gerontology. Dr. Formosa is Chairperson of the National Commission for Active Ageing Malta and Director of the International Institute on Ageing, United Nations - Malta (INIA).

Sabina Jelenc Krašovec, Ph.D., is Associate Professor of adult education at Department of Educational Sciences, Faculty of Arts, University of Ljubljana. Her research and writings focus on the education of vulnerable groups of adults, and more recently, on older adult learning in the community and non-formal contexts.

Bernhard Schmidt-Hertha is Full Professor for Educational Science with a focus on vocational continuing education and on-the-job training at the Eberhard Karls Universitaet Tuebingen, Germany. He is Director of the Institute of Education and Convener of the European Network on Education and Learning of Older Adults ELOA.

\section{AUTHORS}

Alfredo Alfageme holds a Ph.D. in Sociology. He is a Lecturer in Sociology at the Universitat Jaume I Castelló, Spain, where he co-ordinates the sociology of ageing research group. He has headed research on education for older people and on alternative retirement policies.

Ann-Kristin Boström, Special Advisor for the Governments' Offices, and researcher at the National Centre for Lifelong Learning ENCELL, Jönköping University, has her main interest in lifelong learning, intergenerational learning and social capital and is a member of the editorial board of the Journal of Intergenerational Relationships.

António Fragoso holds a Ph.D. in Pedagogy. He is an Assistant Professor at the University of the Algarve. His research has been focused in community education and development and the education of older adults, especially in informal contexts. $\mathrm{He}$ also coordinates research projects on non-traditional students in higher education.

Barry Golding, Professor at School of Education and Arts, Federation University Australia, is also President of Adult Learning Australia and Patron of the Australian Men's Sheds Association. His research on equity and access in adult and community education focuses on men's learning through participation in community organisations, including community men's sheds. 
Paula Guimarães is Assistant Professor at the Institute of Education of the University of Lisbon Portugal since 2012 and used to be Researcher at the Unit for Adult Education of the University of Minho from 1992 to 2011. Her research interests include adult learning and education policies and civil society organizations intervention in adult learning and education. She publishes regularly in European and Portuguese journals and books.

Barry J. Hake studied in the UK and has worked at universities throughout Europe, now retired. He has published widely in books and journals in his specialist fields of comparative history of adult learning and policy analysis of lifelong learning in the European Union. Major focus of his work is on the role of social movements in policy and practice.

Dominique Kern, Ph.D. in Education Sciences, Senior lecturer at the University of Haute Alsace in Mulhouse, Faculty of arts, languages and humanities, member of the Interuniversity Laboratory of Education and Communication Sciences LISEC EA 2310; research focus on epistemology of older adult learning.

Sonja Kump, Ph.D., is a professor of adult education at the University of Ljubljana, Faculty of Arts. Her research interests are oriented on comparative adult and lifelong education, sociology of higher education and evaluation of quality in higher education and research. Currently she examines the impact of learning and education on the quality of life of older adults.

Malgorzata Malec Rawiński, Ph.D., is working at the Institute of Pedagogy, University of Wrocław. Her research work focuses on the old age, ageing, problems and needs of elderly people, learning while being old, education of aging keeping the orientation on biographical learning. Twice, she has been awarded post-doc scholarship within the Swedish Institute Visby Program.

Veronika Thalhammer is research assistant at the Department of Adult Education/Further Education at the University of Tübingen Germany. The principal foci of her current research are on intergenerational and informal learning processes of older adults.

Tarja Tikkanen is a Professor in Education at the Faculty of Teacher and Cultural Education, University College Stord/Haugesund. Her research interests are in lifelong learning in general and in job-competence and competence development in particular. Most of her research has been international, but also national Norway and Finland and regional. 
Esmeraldina Costa Veloso is Assistant Professor at the Department of Social Science of Education, Institute for Education, Minho University, where she lectures and carries scientific research since 1991. Researched topics include Education and Third Age, Third Age Universities as well Policies regarding Adult Education, especially in Portugal..

Georgios K. Zarifis is Assistant Professor of Continuing Education at the Faculty of Philosophy, Department of Education at the Aristotle University of Thessaloniki, Greece. His research interests focus on adult educators' professional development, university continuing education, and comparative examination of adult learning policies and practices in Southeastern Europe. He is an elected Member of ESREA's Steering Committee and co-Convener of ESREA's Research Network on Adult Educators, Trainers and their Professional Development ReNAdET.

Irena Zemaitaityte is Professor at the Institute of Education Science and Social Work, Mykolas Romeris University, Lithuania. Her research areas are education and learning of older people, professional training, non-formal and informal adult education. She is member of the Editorial Board of Societal Studies Research Paper and member of ESREA. 